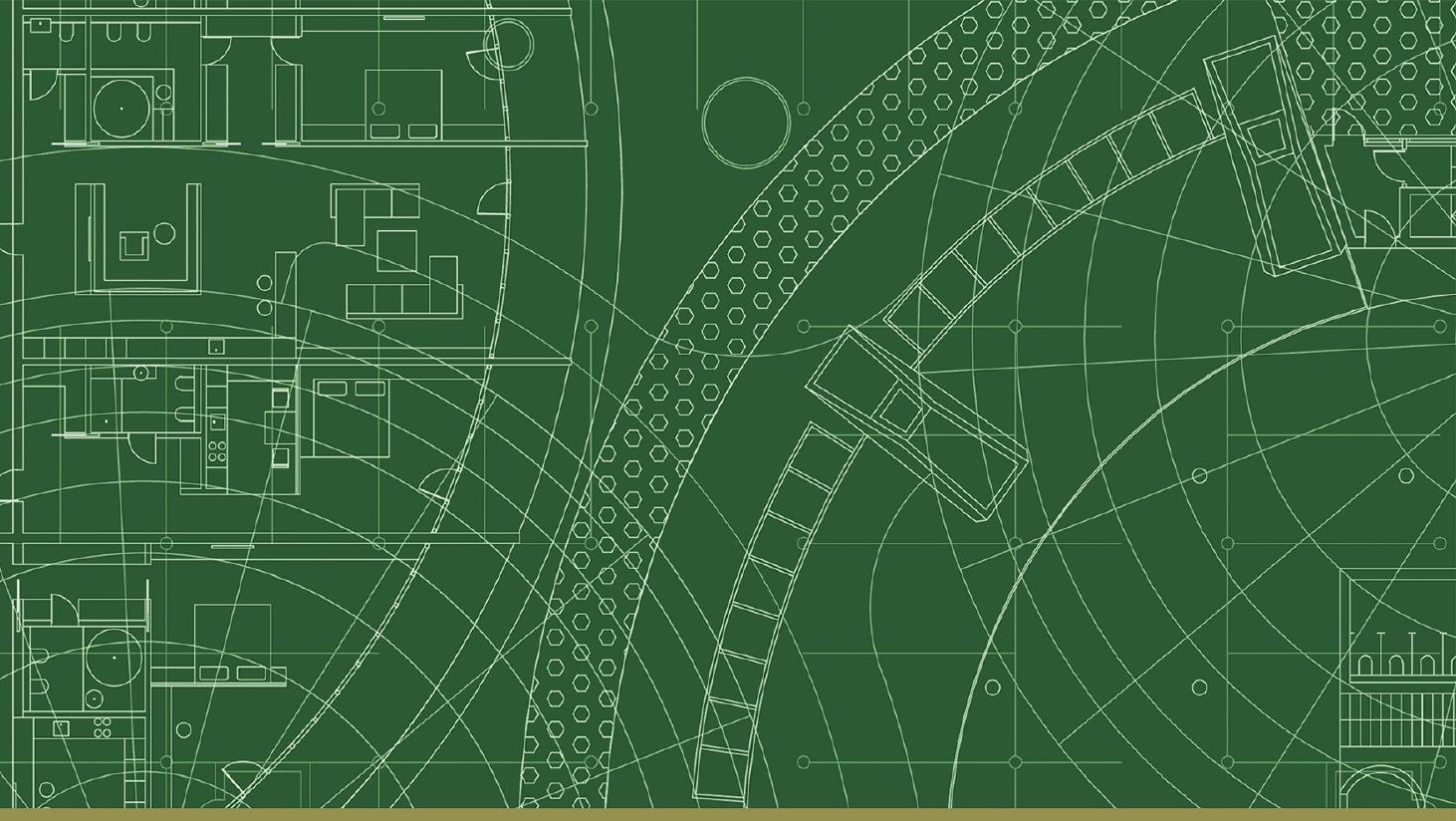

Routledge Frontiers of Criminal Justice

\title{
GENETIC SURVEILLANCE AND CRIME CONTROL
}

SOCIAL, CULTURAL AND POLITICAL PERSPECTIVES

Helena Machado and Rafaela Granja

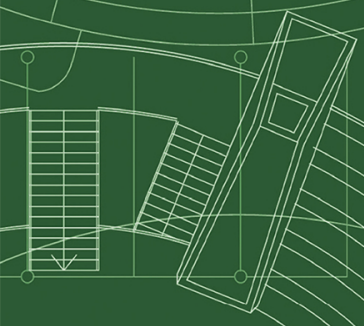


A valuable contribution to Science \& Technology Studies and ongoing discussions on forensic genetics and the governance of crime. The empirical study that informs this book is particularly important in its quest to address social, cultural and political repercussions of using surveillance technologies in our societies.

Diana Miranda, Lecturer in Criminology \& Criminal Justice, Northumbria University, $U K$

This amazing book brings original empirical and conceptual work on forensic genetic technologies in Europe into a dialogue with insights from surveillance studies, critical race theory, Science and Technology Studies, and other relevant fields. I highly recommend it to everyone with an interest in changing notions of social control and citizenship in Europe and beyond.

Professor Barbara Prainsack, Department of Political Science, University of Vienna, Austria

This book provides a timely addition to scholarship on the role of new forensic technologies in the governance of crime. Taking the Prüm system as its starting point and empirical focus, the argument considers different contexts of science production, actors and agencies and the unfolding imaginaries, practices and power relations at play. Making a compelling case for the social study of forensic technologies in situ, the writing illuminates the evolving understandings of biological citizenship, biosociality and inequality. The multi-level analysis is a great resource for all those who wish to have a more informed perspective on the centralised modes of surveillance enabled through forensic genetics across the united Europe.

Dr. Dana Wilson-Kovacs, Department of Sociology, Philosophy and Anthropology, University of Exeter, UK 
$\Longrightarrow$ Taylor \& Francis

Taylor \& Francis Group

http://taylorandfrancis.com 


\section{Genetic Surveillance and Crime Control}

Genetic Surveillance and Crime Control presents a new empirical and conceptual framework for understanding trends of genetic surveillance in different countries in Europe and in other jurisdictions around the world.

The use of DNA or genomes for state-level surveillance for crime governance is becoming the norm in democratic societies. In the post-DNA era, contemporary modes of criminal identification are gradually changing through the increasing expansion of transnational exchange of DNA data, along with the development of highly controversial genetic technologies that pose acute challenges to privacy and generate fears of discrimination, racism, and stigmatization. Some questions that guide this book are: How is genetic surveillance in the governance of crime intertwined with society, ethics, culture, and politics? What are the views and expectations of diverse stakeholders - scientists, police agencies, and non-governmental organizations? How can social sciences research about genetic surveillance accommodate socio-cultural and historical differences and be sensitive to specificities of post-authoritarian societies in Europe?

Taking an interdisciplinary approach focused on challenges to genetic privacy, human rights, and citizenship in contemporary societies, this book will be of interest to students and scholars of social studies of science and technology, sociology, criminology, law and policing, international relations, and forensic sciences.

Helena Machado is Professor of Sociology at the Institute for Social Sciences, University of Minho, Portugal.

Rafaela Granja is a researcher at the Communication and Society Research Centre (CECS), University of Minho, Portugal. 


\section{Routledge Frontiers of Criminal Justice}

Emotional Labour in Criminal Justice and Criminology

Edited by Jake Phillips, Chalen Westaby, Andrew Fowler and Jaime Waters

Predictive Policing and Artificial Intelligence

Edited by John L.M. McDaniel and Ken G. Pease

The Use of Victim Impact Statements in Sentencing for Sexual Offences

Stories of Strength

Rhiannon Davies and Lorana Bartels

Understanding the Educational Experiences of Imprisoned Men

(Re)education

Helen Nichols

Professionalism in Probation

Making Sense of Marketisation

Matt Tidmarsh

Policing Child Sexual Abuse

Failure, Corruption and Reform in Queensland

Paul Bleakley

Collaboration and Innovation in Criminal Justice

An Activity Theory Alternative to Offender Rehabilitation

Paulo Rocha

Genetic Surveillance and Crime Control

Social, Cultural and Political Perspectives

Helena Machado \& Rafaela Granja

For more information about this series, please visit: www.routledge.com/ Routledge-Frontiers-of-Criminal-Justice/book-series/RFCJ 


\section{Genetic Surveillance and Crime Control}

Social, Cultural, and Political Perspectives

\section{Helena Machado and Rafaela Granja}


First published 2022

by Routledge

2 Park Square, Milton Park, Abingdon, Oxon OX14 4RN

and by Routledge

605 Third Avenue, New York, NY 10158

Routledge is an imprint of the Taylor \& Francis Group, an informa business

(C) 2022 Helena Machado \& Rafaela Granja

The right of Helena Machado \& Rafaela Granja to be identified as authors of this work has been asserted by them in accordance with sections 77 and 78 of the Copyright, Designs and Patents Act 1988.

Trademark notice: Product or corporate names may be trademarks or registered trademarks, and are used only for identification and explanation without intent to infringe.

The Open Access version of this book, available at www.taylorfrancis.com, has been made available under a Creative Commons Attribution-Non Commercial-No Derivatives 4.0 license.

British Library Cataloguing-in-Publication Data

A catalogue record for this book is available from the British Library

Library of Congress Cataloging-in-Publication Data

A catalog record has been requested for this book

ISBN: 978-0-367-20433-4 (hbk)

ISBN: 978-0-367-52141-7 (pbk)

ISBN: 978-0-429-26143-5 (ebk)

DOI: $10.4324 / 9780429261435$

Typeset in Times New Roman

by Taylor \& Francis Books 


\section{Contents}

List of tables viii

Acknowledgments $\quad$ ix

Preface: The Right Place of Forensic DNA Technologies xi

1 Introduction 1

2 Forensic Genetics and Genetic Surveillance in Europe: A

Historical and Sociological Analysis 22

3 Transnational Genetic Surveillance in the EU: The Case of the Prüm System 49

4 Genetic Surveillance in Post-Communist European Countries 71

5 The Uses of Familial Searching In Europe: At The Crossroads Between Expanding Suspicion And Historical Reparation 94

6 Expanding Genetic Informativity Through Emerging Technologies: The Cases of Forensic DNA Phenotyping and Next Generation Sequencing

7 Non-Governmental Organizations and the Critique of Genetic Surveillance

8 Conclusion 178

$\begin{array}{ll}\text { Index } & 191\end{array}$ 


\section{Tables}

1.1 Governance in forensic genetics applied to criminal investigation 4

1.2 Genetic surveillance 6

2.1 Waves of technological innovations in forensic genetics 28

2.2 Size of several forensic genetic databases in Europe 32

2.3 Visions about DNA profiling 36

3.1 Summary of expectations being met and challenges, according to different NCPs 65

4.1 Characteristics of forensic DNA databases in CEE countries 77

5.1 Types of familial searches 95

5.2 Familial searching in criminal investigation $\quad 106$

5.3 National DNA analysis files available for exchange within Prüm 114

6.1 Technologies that expand genetic informativity 124

7.1 Summary of NGOs' role and mission in the field of forensic genetic technologies

$\begin{array}{ll}\text { 7.2 Modes of data politics } & 171\end{array}$ 


\section{Acknowledgments}

This book is the result of many collaborations and support over several years, and as such it is an impossible mission to present and thank all the contributions that the authors received and benefited from. In this brief note, we will do our best to provide fair credit to all those who, at different times, have provided invaluable support, without which this work would not have been produced.

First, we are deeply thankful for the comments, insights, friendship and inspiration generously provided, between 2015 and 2020, by the permanent members of the Exchange research team, funded by the European Research Council, through a Consolidator Grant attributed to Helena Machado (ERC Grant Agreement no. 648608): Nina Amelung, Sheila Khan, Filipa Queirós, Marta Martins, Sara Matos, and Laura Neiva. We also thank the collaboration of Filipe Santos and Alícia Wiedemann at different stages of the project.

The support of the Exchange Scientific Committee was also fundamental for the development of the Exchange project: Amade M'charek (University of Amsterdam, The Netherlands), Barbara Prainsack (University of Vienna, Austria \& Kings College London, UK), Peter Schneider (University of Cologne, Germany), Robin Williams (Northumbria University, UK), and Kees van der Beck (Netherlands Forensic Institute, The Netherlands).

Colleagues from different institutions and universities presented us with stimulating debates, constructive criticism and reflexive challenges. At the risk of omission, however, we would like to highlight the extraordinary intellectual contribution of Susana Silva and António Amorim (University of Porto, Portugal); Catarina Fróis (ISCTE, University Institute of Lisbon, Portugal); Francisco Corte-Real (University of Coimbra, Portugal); Tiago Santos Pereira, Susana Costa, and Margarida Calafate Ribeiro (Centre for Social Studies, Portugal); Ángel Carracedo Álvarez and Christopher Phillips (University of Santiago de Compostela, Spain); Carole McCartney and Matthias Wienroth (Northumbria University, UK); Dana Wilson-Kovacs (University of Exeter, UK); David Skinner (Anglia Ruskin University, UK); Gabrielle Samuel (Kings College London, UK); Sarah Abel (University of Cambridge, UK); Victor Toom (Netherlands Scientific Council for Government Policy); Joëlle Vailly (Centre National de 
Recherche Scientifique, France); Cláudia Fonseca (Federal University of Rio Grande do Sul, Brazil); and Taysa Schiochet (University of Paraná, Brazil).

The central empirical object of this book is the so-called Prüm system, a transnational network of police and judicial cooperation for exchanging DNA profiles and other information of interest to combat crime in the European Union. In the empirical operationalization of the project, the collaboration of Georg Biekötter (Council of the European Union), Reinhard Schmid (Federal Ministry of the Interior, Austria) and Ingo Bastisch (Bundeskriminalamt, Germany) were particularly important. We are also deeply grateful to all participants in the empirical study that gave rise to this book: all forensic geneticists, professionals linked to the Prüm system, representatives of nongovernmental organizations working in the area of human rights and science, specialists in law, and other stakeholders who generously shared their time and experiences.

Centre for Social Studies (CES, University of Coimbra) and Communication and Society Research Centre (CECS, University of Minho) provided crucial administrative and logistical resources at key moments in the project's development. We would like to thank Boaventura de Sousa Santos (CES), Moisés Martins (CECS), and Filipe Vaz (University of Minho) for their hospitality and great institutional support to the Exchange team. We are deeply grateful for the administrative assistance of João Paulo Dias, Irina Castro, Rita Pais, Alexandra Pereira, Ana Gonçalves, and Miguel Aguiar.

We are deeply thankful to the great editorial team of Routledge, and to Laura Neiva and Diogo Freitas da Costa who provided us with superb research assistance at various stages in the book's evolution and proofreading. We also would like to thank the complementary support of the Portuguese Foundation for Science and Technology through the grants IF/00829/2013, CEECIND/00984/2018 and UIDB/00736/2020.

Our family was always present and was almost as excited as we are about the adventure of writing this book: thank you José, Sofia, Maya, Paula, Zacarias, Igor, Mel, and Bóris. 


\title{
Preface: The Right Place of Forensic DNA Technologies
}

\author{
Barbara Prainsack
}

I started being interested in forensic DNA technologies in the early 2000s, when many countries in Europe and worldwide were setting up national forensic DNA databases. I had spent several years studying the governance of genomic technologies in the medical domain and was struck by how some of the core ethical and governance-related concerns in medical genomics were absent in forensics: such as questions about truly free and informed consent, which were so prominent in the medical domain. Similarly, in the medical context, the focus was on protecting the autonomy and interests of patients, while in forensics the main interests to be protected were those of the victim and her family, as well as society as a whole. The balance between individual and public interests, so it seemed, was struck very differently in the two domains.

Up to this day, the ontologies inscribed in data protection frameworks in Europe and beyond reflect these different rationalities. While genetic information is classified as sensitive personal data within the General Data Protection Regulation (GDPR), ${ }^{1}$ and particularly strict rules regarding the processing and use of genetic personal data apply, the processing of genetic information for law enforcement purposes by "competent authorities" 2 is removed from the remit of the GDPR and regulated in the Police Directive, ${ }^{3}$ where some consent requirements are suspended for the purpose of public interest.

While it could be argued that this division of focus on (a) protecting the interests of data subjects in the domain of medicine vs. (b) protecting the interests of the public and third parties in the domain of forensics is selfevidently justified, owing to the different purposes that medicine and forensics serve (improving the health of the data subject in the former, and protecting society on the other), one of the many insights that this important book yields is how such a stance is no longer tenable. The idea of a fundamental tension between individual vs. public interests is problematic for empirical and conceptual reasons: First, it implies a conflation of the level of the specific and the level of the general. Although the interests of an individual person can, in specific circumstances, very well conflict with public interests (the paradigmatic 
case is the tension between individual privacy vs. societal security), the goals of protecting the rights of individuals, including convicts, arrestees, and suspects - and serving public interests are not conflicting goals in principle. The relationship between individual and public rights is not a zero-sum game where one can be "traded" for a bit of the other (see also Pavone et al., 2018 and Samuel \& Prainsack, 2019). Security and privacy are both individual and collective concerns at the same time.

Or they should be.

While it is largely uncontroversial that security is a public good, its meaning has changed in recent decades, and these changes make it easy to forget that security, embedded in a democratic system, is there to serve and respect the rights of everyone, instead of undermining the rights and interests of individuals or groups that are seen as undeserving in one way or another. As Vincenzo Pavone and colleagues argue, over the last two decades alone:

the concept of security [...] has shifted from territorial integrity and national sovereignty to human security and, after $9 / 11$, to a new concept of homeland security. New security policies have particularly encouraged pre-emptive security measures, enacted through the development of dataintensive security technologies and public-private security collaboration. These measures have been introduced within policy frameworks which justify the restriction of individual privacy and freedom - a matter of political concern.

(Pavone et al. 2018: 640)

Genetic technologies play a prominent role in this development. As Helena Machado and Rafaela Granja observe, "|the nature of genetic surveillance is [...] opening the path to extend the fabric of suspicion towards a prospective surveillance" (Introduction, page 6). This is closely linked to the political process of reframing social problems as problems of security, including demographic and social transformations such as migration - and most recently also the Covid-19 pandemic (e.g. Lazaridis \& Wadia, 2015).

At this critical juncture, it is more important than ever to remember that the entitlement of individual persons to security is an important manifestation of security as a public good. This individual entitlement is enshrined in several human rights declarations and frameworks including the UN Declaration of Human Rights (1948). In Europe, the European Convention on Human Rights, under Article 5.1, provides that "[e]verybody has the right to liberty and security of the person," while Article 6 of the Charter of Fundamental Rights of the European Union provides that "[e]veryone has the right to liberty and security of the person" (which is to be interpreted along the lines of Article 5.1 of the European Convention of Human Rights).

Individual entitlements to security are closely associated with liberty and the freedom of bodily movement as well as physical integrity vis-à-vis state 
institutions (they are seen by some as an expansion of rights based on the prohibition of torture and cruel and unusual punishment). In other words, the substance of the right to security aims to protect people also from undue interference by state agencies and public authorities. Moreover, the state holds the monopoly on violence as a representative of the sovereign, the people. This means that the exercise of the monopoly on violence must be democratically legitimized, transparent, and publicly accountable. Most European states have functioning legal principles, norms, and processes in place to ensure that this is so. Part of these legal principles and norms are the protections of human rights and public goods that can conflict, in concrete situations, with the rights and public goods that forensic genetic technologies - as part of the tool box of criminal justice - seek to protect and foster. But this does not change the fact that neither security, nor privacy, can be realized at the collective or individual level respectively.

Besides this conceptual caveat against a view that plays out public interest in security against individual rights and interests there are also empirical reasons for seeing the two as connected. As Helena Machado and Rafaela Granja convincingly show in this book, while cutting-edge technologies of previous periods, such as short-term random (STR)-based DNA profiling, aimed at linking a specific individual to a specific crime scene based on discrete pieces of evidence, more recent technologies draw much wider ranges of information into the process of criminal investigation and crime prevention. In the context of next generation sequencing technologies, even if an analysis aimed at merely obtaining STR data, other data, such as on a person's phenotypic characteristics, is available as a byproduct. This facilitates function creep, meaning that data that were collected and analysed for a specific purpose are used for a wider range of purposes "because they're available" (Dahl \& Saetnan, 2009). Forensic DNA phenotyping - namely the inference of externally visible traits, such as skin, eye, and hair colour - from coding parts of the DNA sample could be seen as an instance of such function creep. Although there are certainly good arguments for how forensic DNA phenotyping can be used responsibly in specific circumstances (Samuel \& Prainsack, 2020), it also bears the risk of foregrounding technological solutions at the cost of divesting from other, low-tech means of criminal investigation (e.g. properly funded and high quality police work). And it means - in both the case of familial searching and forensic DNA phenotyping, as also shown in this book - that the analysis of one DNA sample draws several people - or even entire groups - into the investigation. Familial searching extends the range of people who the technology could throw suspicion on to biological relatives of people whose profiles are stored in the forensic DNA database. In the case of phenotypic profiling, if an analysis shows that the perpetrator most likely had a particular skin, eye, and hair colour, entire groups could become a suspect population, raising concerns about ethnic and racial discrimination.

Even more urgently than the medical domain, forensic genetics needs legal and ethical instruments that reflect the relational nature of people and of data 
(McMahon et al., 2020). We need instruments that better reflect the situation that restrictions of individual privacy and autonomy always also change the nature of the collective; and that public goods and interests such as security always manifest themselves also at the level of groups, families, and individuals.

Through the lens of forensic genetics, this book tells a story about the changing nature of social control and citizenship in Europe and beyond. The authors show how systems of forensic genetic surveillance do not only help to solve and prevent crime, but they also expose - and in some cases, exacerbate - the fault lines and differences in our societies. Within the tool box of forensic technologies, genetic and genomic practices play a particularly important role because of the intimate connection that genetic information is assumed to have with the person: They are seen to "capture the very essence of that body and turn it into information" (Introduction, page 2). Against this backdrop, it is more important than ever to analyse, as this fantastic book does, how technologies are never merely neutral tools that, in the service of good or evil intentions, are used for good or evil purposes in society. Independent of the intentions of those that develop and deploy them, forensic genetic technologies have dominant values, hierarchies, and power relations of the societies from which they emerged inscribed in them. Engagement with forensic genetic technologies is thus an important part of democratic control and practice of our time.

\section{Notes}

1 Article 4(13) considers "genetic data" (next to "data concerning health", and "biometric data") a special category data that deserves specific protection. It also gives the right to Member States to "maintain or introduce further conditions, including limitations, with regard to the processing" of these types of data (Article 9(4). For further details on the GDPR and genomic data in the clinical genetics context, see PHG Foundation 2020.

2 "Competent authorities" in this definition comprise (a) public authorities competent for the law-enforcement purposes set out in Article 1.1 of the Police Directive, and (b) "any other body or entity entrusted by national law to exercise public authority and public powers" for the law enforcement purposes set out in Article 1.1 (e.g. a privately owned company running a prison; see Purtova [2018]). When a body not meeting the "competent authority" criteria processes data for law enforcement purposes, such as a financial institution, at the order of a public authority the GDPR, and not the Police Directive, applies (e.g. a financial institution processes personal data that a law enforcement authority has requested in connection with an open investigation) (see also Samuel \& Prainsack 2018).

3 For the purpose of collecting and storing information for police and forensic uses, a lex specialis to the more general EU Data Protection Directive entered into force in May 2016: The "Directive 2016/680 on the protection of natural persons with regard to the processing of personal data by competent authorities for the purpose of law enforcement" (we called it Police Directive; see Samuel \& Prainsack 2018). It replaced the data protection rules based on the Framework Decision 2008/977/JHA for the police and criminal justice sector, with the aim of removing barriers to information exchange for law enforcement purposes between member countries by 
harmonising and simplifying rules. Member countries had to translate the Directive into national law; they were allowed to require higher data protection standards than those prescribed in the Police Directive, but not lower ones. In a nutshell, important differences between the GDPR and the Police Directive lie in the grounds for lawful processing and in the powers of processing authorities. The grounds for lawful processing in the Police Directive are much narrower than in the GDPR (see in particular Article 8.2, and Article 10 Police Directive): "Competent authorities" processing for the purpose of law enforcement do have more leeway in how they use data than data controllers or processors within the GDPR. Correspondingly, the information rights of data subjects within the Police Directive are more limited than the information rights of data subjects under the GDPR regime (for details see also Purtova 2018).

\section{References}

Dahl, J.Y. and Sætnan, A.R. (2009). "It all happened so slowly"-On controlling function creep in forensic DNA databases. International Journal of Law, Crime and Justice, 37(3), 83-103.

Lazaridis, G. and Wadia, K., eds. (2015). The Securitisation of Migration in the EU: Debates since 9/11. Springer.

McMahon, A., Buyx, A., and Prainsack, B. (2020). Big data governance needs more collective responsibility: the role of harm mitigation in the governance of data use in medicine and beyond. Medical Law Review, 28(1), 155-182.

Pavone, V., E. Santiago Gomez, and D.-O. Jaquet-Chifelle. (2016). A Systemic Approach to Security: Beyond the Tradeoff between Security and Liberty. Democracy and Security, 12 (4): 225-246.

Public Health Genomics (PHG) Foundation. 2020. The GDPR and genomic data - the impact of the GDPR and DPA 2018 on genomic healthcare and research. Cambridge, UK. Available at: www.phgfoundation.org/documents/gdpr-and-genomic-da ta-report.pdf.

Purtova, N. (2018). The law of everything. Broad concept of personal data and future of EU data protection law. Law, Innovation and Technology, 10(1), 40-81.

Samuel, G. and Prainsack, B. (2018). The regulatory landscape of forensic DNA phenotyping in Europe. VISAGE Project Report. Available at: www.visage-h2020.eu/ PDF/Deliverable_5.1_for_posting_online_DECEMBER_2018.pdf.

Samuel, G. and Prainsack, B. (2019). Societal, ethical, and regulatory dimensions of forensic DANN phenotyping. VISAGE Project Report. Available at: www.visa ge-h2020.eu/PDF/Delliverable_5.2_for_online_publication_vo1.pdf.

Samuel, G. and Prainsack, B. (2020). Report on recommendations to address the ethical and societal challenges of FDP. VISAGE Project Report. Available at: www. visage-h2020.eu/PDF/Recommendations_for_website.pdf. 
$\Longrightarrow$ Taylor \& Francis

Taylor \& Francis Group

http://taylorandfrancis.com 


\section{Introduction}

\section{Introduction}

A striking aspect of 21st-century societies in the governance of crime is the growing role of scientific and technological innovations in the field of forensic genetics. The aim of forensic genetics is to identify individuals through the collection of their biological traces - blood, hair, saliva, or other fluids. The possibility of deriving DNA (a biological structure considered unique to each individual) from biological matter - whether inadvertently left behind by criminal suspects at crime scenes or directly obtained from the bodies of criminal suspects - has contributed decisively in predisposing governments to support the developments and ambitions of forensic genetics. This book aims to explore some of the complex and multidimensional social, cultural, and political implications of forensic genetics' uses in security and criminal law activities. We intend to provoke critical thinking about the repercussions of forensic genetics on the nature of social control and citizenship in contemporary societies, viewed through the lens of social science research and taking as our starting point the social phenomenon of genetic surveillance in the governance of crime. By genetic surveillance we mean the acts involved in the systematic monitoring of individuals or groups based on their genetic body specificities in order to detect and/or reconstruct a crime. By governance we refer to a cluster of social values and norms, expectations, and practices of conduct and decision making, as well as institutional provisions taken both by governmental and non-governmental actors.

The present volume is based on a six-year investigation (the "Exchange project"1) aimed at studying the expectations of scientists, international security professionals and other stakeholders with a direct interest in the technical development of forensic genetic technologies and criminal DNA databases in Europe. The study was guided by the following overarching research questions: how is genetic surveillance in the governance of crime intertwined with society, ethics, culture, and politics? To what extent and how significantly are the views and expectations related to genetic surveillance reflected in the discourses of diverse stakeholders? What are the social

DOI: $10.4324 / 9780429261435-1$ 


\section{Genetic Surveillance and Crime Control}

identities, power relations, hierarchies and asymmetries that emerge from this process? Our interrogations also imply a critical reflection on the role of genetic surveillance in shaping contemporary societies. More concretely, it helps us to understand how social life has come to be imagined as explicable and governable through the decoding and manipulation of genetic material (Hacking, 2006; Nelkin \& Lindee, 1995; Rabinow, 1996), at a historical period when DNA came to be described as the single most important element of human identification (Cole, 2001).

In 1985 Alec Jeffreys and colleagues published an article in Nature, entitled "Individual-specific 'fingerprints' of human DNA," that has since become an inaugural chapter in the story of the uses of genetics for human identification purposes. The author presented a technique using highly variable segments of DNA “... to produce somatically stable DNA "fingerprints" which are completely specific to an individual (or to his identical twin) and can be applied directly to problems of human identification..." (Jeffreys, Wilson, \& Theint, 1985, p. 76). The technology of DNA profiling promised to provide reliable knowledge of individual human subjects, rendering the body as a system of standardized and repeatable properties. However, unlike many other techniques of bio-identification, like fingerprints or anthropometry, the analysis of DNA is not constructed from an impression of the body or through the manipulation of the body's visible aspects; instead, forensic genetics goes "under the skin," allowing to capture the very essence of that body and turn it into information (Lyon, 2001; Van Der Ploeg, 2005; Williams, 2010).

The introduction of DNA profiling into the criminal justice system began in 1988, when Englishman Colin Pitchfork became the first person to be convicted through the use of DNA evidence. The case gave rise to highly optimistic social expectations about the practical application of this method and its evidentiary value in the formal accusation and prosecution of criminal offenders. In the decades that followed, broader global networks of scientists, biotechnology companies, stakeholders, and end-users (e.g., police institutions and the justice system) stabilized DNA as a powerful tool of justice, establishing the general consensus that genetics technologies should play a vital role both in courts and in criminal investigation activities (Aronson, 2007; Lynch et al., 2008). However, along with its stabilization processes, the innovations in forensic genetics also combine a variety of relatively unstable social formations, insofar as they are being continually co-constructed and reshaped (Granja, 2020; Granja \& Machado, 2020; Kennett, 2019; Lawless, 2012; Samuel \& Prainsack, 2018; Wienroth, 2018).

In the aftermath of the stabilization process of DNA profiling, one of the most prominent aspects of forensic genetics' use in the criminal justice system has been the growth of national forensic DNA databases as a means of storing, searching, and comparing crime scene DNA profiles with profiles from known individuals obtained and retained under a variety of legal regimes (Reed \& Syndercombe-Court, 2016; Santos, Machado, \& Silva, 2013). This has been possible through a combination of technical, organizational and 
legislative developments which include: improvements in DNA extraction and analysis; the establishment of national and international laboratory standards; the judicial avowal and trust in the robustness of DNA evidence; and the creation of new technical and scientific working groups and associations, at national and international levels, thus stabilizing the epistemic and ontological status of DNA profiling (Derksen, 2010; Lawless, 2012; Lynch \& McNally, 2009).

Alongside these technical and scientific developments, accompanied by changes in legislation and in criminal justice procedures - a process that Michel Lynch and Ruth McNally designated as "biolegality" (Lynch \& McNally, 2009) - we witnessed a series of political and historical transformations that ideologically legitimized - and continue to legitimize - the expansion of surveillance based on the creation of large-scale information technology database systems. The increasing interoperability of forensic DNA databases which, albeit nationally based, are also engaged in transnational comparing and exchange of DNA profiles and other kinds of data, is a clear example of the expansion of genetic surveillance (Amelung, Granja, \& Machado, 2020; Machado \& Granja, 2018; McCartney, 2014; Prainsack \& Toom, 2010, 2013). The technological innovations in the domain of storing and exchanging of DNA data are accompanied by issues of safety and security related with broad social and political concerns about terrorism and crime, and they are embodied in a variety of biometric surveillance systems.

Another important historical turn is what we call a post-DNA era, in which the ambitions for genetic informativity are amplified, thereby shifting the focus of forensic science from the construction of evidence to the generation of intelligence considered valuable to criminal investigations (Machado \& Granja, 2020; Wienroth, 2018). The move from genetic to genomics, which has been blurring the general accepted boundary between "non-informative" and "informative" genetic markers, ushers the advent and consolidation of technologies that allow a speculative generation of criminal suspects based on information provided by DNA profiles, such as forensic DNA phenotyping (FDP) and next generation sequencing (NGS) (Amorim \& Pinto, 2018; Granja \& Machado, 2020; Samuel \& Prainsack, 2018; Wienroth, 2018). In this introduction we explore some of the ramifications stemming from this progress of transition from genetics to genomics in the criminal identification area.

The work of Robin Williams accurately outlines the interrelated social and epistemic domains comprising the typical focus of DNA profiling and DNA databasing governance, namely: the juridical-scientific, the operational, and the ethico-political domains (Williams, 2010, pp. 140-147). From the author's perspective, the juridical-scientific involves the subjection of DNA profiling and DNA evidence production to a legal framework that both enables and limits the management of DNA profile data, as well as their legitimate uses and resistance to judicial and scientific challenges. The operational domain pertains to the assessment of criminal DNA databases' effectiveness and 


\section{Genetic Surveillance and Crime Control}

efficiency for policing and other crime governance-related activities. The ethico-political domain relates to civil liberties and human rights, namely in terms of the monitoring and independent scrutiny over the operation and uses of DNA databases, as well as issues of public trust in governance. Based on the existing literature on the governance of forensic genetic technologies in the security and criminal law fields, the following table provides a summary of the most recurrent themes and issues:

Table 1.1 Governance in forensic genetics applied to criminal investigation

\begin{tabular}{|c|c|c|c|}
\hline Domains & Stakeholders & Practice & Potential issues \\
\hline Juridico-scientific & $\begin{array}{l}\text { Scientists and } \\
\text { policymakers }\end{array}$ & $\begin{array}{l}\text { Legal framework } \\
\text { (admissibility of } \\
\text { DNA evidence in } \\
\text { court) } \\
\text { Procedures and } \\
\text { standards for man- } \\
\text { agement and use of } \\
\text { DNA profiling and } \\
\text { databasing }\end{array}$ & $\begin{array}{l}\text { (Lack of) legit- } \\
\text { imation of criteria } \\
\text { for inclusion/ } \\
\text { retention of DNA } \\
\text { data (which can } \\
\text { have either expan- } \\
\text { sive or restrictive } \\
\text { effects) } \\
\text { (Lack of) utility } \\
\text { and reliability }\end{array}$ \\
\hline Operational & $\begin{array}{l}\text { Laboratory practi- } \\
\text { tioners, police } \\
\text { agencies, courts, } \\
\text { and oversight } \\
\text { bodies }\end{array}$ & $\begin{array}{l}\text { Quality assurance, } \\
\text { reliability, and } \\
\text { oversight of } \\
\text { operations }\end{array}$ & $\begin{array}{l}\text { Use of flawed } \\
\text { random match } \\
\text { probabilities } \\
\text { "CSI" effect } \\
\text { Contamination, } \\
\text { mistakes, false } \\
\text { positives or false } \\
\text { negatives } \\
\text { Backlog in dele- } \\
\text { tion of profiles } \\
\text { that might no } \\
\text { longer be used }\end{array}$ \\
\hline Ethico-political & $\begin{array}{l}\text { Civic organiza- } \\
\text { tions, academics, } \\
\text { and other critical } \\
\text { commentators }\end{array}$ & $\begin{array}{l}\text { Monitor and advi- } \\
\text { sory role }\end{array}$ & $\begin{array}{l}\text { Privacy risks } \\
\text { Stigmatization } \\
\text { Function creep } \\
\text { (widening the } \\
\text { scopes of uses for } \\
\text { purposes other } \\
\text { than those for } \\
\text { which the technol- } \\
\text { ogy or database } \\
\text { was designed) } \\
\text { Surveillance and } \\
\text { social sorting }\end{array}$ \\
\hline
\end{tabular}

Source: Authors, inspired by Williams (2010).

This book aims to expand the academic debate around the governance of forensic genetics, by expanding the approach proposed by Robin Williams to encompass the "juridico-scientific," "operational" and "ethico-political" domains 
(see Table 1.1). Williams' approach broadens the horizons and opens new ways to address technologies of control and their implications on our conceptions of the human, justice and the role of science at a time that might be described as a postDNA era, insofar as forensic analyses are increasingly converging toward the study of the human genome. As we reflect upon the social, cultural, ethical and political implications of genetic technologies, we need to look more closely at the modes of individual and collective social identity performativity, as well as to imaginaries of nationhood and historical trajectories that condition the relations between the state and its citizens (rendering them to a greater or lesser degree predisposed to release sensitive data), in the context of a society which has been won over by the promises of genetics and is enthralled with the processes of datafication.

\section{Genetic surveillance}

The expansion of forensic genetic technology uses and centralized DNA databases in different regions around the world, is often criticized as part of an ever-widening system of genetic surveillance, through which biological tokens of identification are becoming increasingly vital (Hindmarsh \& Prainsack, 2010; Williams \& Johnson, 2008). Compiled into computerized databases, DNA identifiers provide the raw material for constructing innumerable knowable and manageable individuals, groups and populations, rendering them increasingly vulnerable to governments' data-driven crime control ambitions. In this book we analyse and critically reflect upon the social phenomenon constituted by the growth, in breadth and scope, of genetic technologies and forensic DNA databases at national and transnational levels, and their involvements with other surveillance systems. Specifically, we will address how the governance of crime through genetic surveillance encapsulates more than the social, technical-scientific response to crime. It also incorporates new possibilities for monitoring and controlling behaviors, as well as reconfigurations of justice administration through which new concepts of order and social control are co-constructed to fit what some authors have called "the new surveillance," a phenomenon that became increasingly prominent towards the end of the 20th century (Marx, 2002).

The collection of large amounts of genetic profiles and other data of interest for crime governance, in computerized forensic databases, does not bear upon individuals alone; it enables social sorting through increasingly elaborate means, in terms of its impact and reach. In other words, genetic data provides growing opportunities for monitoring and controlling particular individuals and specific social groups that are more vulnerable to become what Richard Hindmarsh and Barbara Prainsack designated as "genetic suspects" (Hindmarsh \& Prainsack, 2010). Social sorting refers to the breakdown and classification of raw data pertaining to groups or persons into various categories. The term was coined and developed by David Lyon in reference to the discriminatory effects of surveillance, namely its potential to 
facilitate profiling and screening specific social groups (Lyon, 2002). Within the wider scope of this book, we also seek to contribute to expand the discussion on the role of genetic technologies and DNA databases in assigning individuals to groups that are already over-policed, thus subjecting them to special forms and implications of surveillance (Cole, 2018; Skinner, 2018). Moreover, understanding the modes of crime governance enacted through genetic surveillance also allows us to look beyond the strict role of state structures in governing current societies, including other social institutions and social actors who also constitute the backbone of the crime governance in contemporary societies. In the case of forensic genetics, this includes, among other social actors: laboratory technicians, forensic genetics researchers, police forces, judges, prosecutors, attorneys, jurors, professional organizations, supervising entities, non-governmental entities, and politicians.

The seminal work of Robin Williams and Paul Johnson (2004) is relevant here for its analysis of the unique nature of surveillance operated by DNA data and its implications for the construction of suspicion and for social sorting through genetic surveillance. The authors argue that DNA databases allow for "reconstructive surveillance," forming a circuit system of surveillance containing information which can be used retrospectively, meaning that people and their actions are not visually monitored, but are inferentially reconstructed by expert practices of geneticists and forensic practitioners (Williams \& Johnson, 2004, pp. 3-6). As the authors explain, DNA databases form "a type of surveillance which is essentially concerned with 'management' of those already deemed criminal (...) delimiting them from the wider population and managing them through assured detection" (Williams \& Johnson, 2004, p. 11).

However, the nature of genetic surveillance is currently undergoing profound changes. No longer solely restricted to a retrospective reach, by focusing on already criminalized individuals, the post-DNA era is opening the path to extend the fabric of suspicion towards a prospective surveillance (see Table 1.2 below).

Table 1.2 Genetic surveillance

\begin{tabular}{|c|c|c|c|}
\hline Type of surveillance & Technologies & Type of analysis & Ethical issues \\
\hline $\begin{array}{l}\text { Reconstructive } \\
\text { surveillance }\end{array}$ & $\begin{array}{l}\text { Forensic DNA } \\
\text { databases } \\
\text { Transnational } \\
\text { exchange of DNA } \\
\text { data (Prüm system) }\end{array}$ & $\begin{array}{l}\text { Based upon non- } \\
\text { codifying genetic } \\
\text { markers (STRs) }\end{array}$ & $\begin{array}{l}\text { Genetic privacy } \\
\text { Proportionality } \\
\text { Overrepresentation } \\
\text { of minority groups } \\
\text { in database }\end{array}$ \\
\hline $\begin{array}{l}\text { Prospective } \\
\text { surveillance }\end{array}$ & $\begin{array}{l}\text { Forensic DNA } \\
\text { phenotyping } \\
\text { Next generation } \\
\text { sequencing } \\
\text { Long-range } \\
\text { familial searches }\end{array}$ & $\begin{array}{l}\text { Based upon } \\
\text { codifying genetic } \\
\text { markers (SNPs) }\end{array}$ & $\begin{array}{l}\text { Collectivization of } \\
\text { suspicion } \\
\text { Stigmatization } \\
\text { Discrimination }\end{array}$ \\
\hline
\end{tabular}

Source: Authors. 
Emergent and still controversial genetic technologies based on human genome analysis are gradually changing the contemporary modes of genetic surveillance.

Recent works in the domain of social studies on forensic genetics have shown that technologies such as FDP, familial searches, and NGS do not produce an individual suspect, but instead generate a suspect population (Granja \& Machado, 2020; Wienroth, 2018). At the same time, the increasing role played by the biologization of appearance, reinforced through genetic technologies that allow to "predict" the visible external characteristics of the human body, contribute to reinforce stigmatization of particular ethnic and racial groups (Hopman \& M'charek, 2020; M'charek, 2020). Prospective surveillance thus emphasizes the continuous transfers between the individual and the collective (M'charek \& Wade, 2020) that increasingly shift the locus from individualization - that is, identification of specific individuals - to socially (and scientifically) constituted notions of human populations (Machado \& Granja, 2020).

In Europe, genetic surveillance with the purpose of governing crime stems from the idea of rationalizing and managing the social order through science and law. Fragmenting bodies into their lowest units makes it possible to group individuals into population groups, stripping them of their individuality, but allowing states to reach the point of biological uniqueness through genetics, while continuously sorting individuals into groups that will distinguish between law-abiding and criminal citizens.

\section{The study}

This book is theoretically aligned with an essentially constructivist and interpretive perspective, in which we analyze the discourses of forensic geneticists, police professionals involved in transnational operations involving DNA data exchange, laboratory practitioners, and civil society organizations engaged in human rights protection in the specific area of genetics and/or biometrics. This book was based on an empirical study that had its starting point in a system implemented by the European Union (EU), which clearly highlights the role of forensic genetics in the governance of crime. We are referring to the transnational network for the exchange of DNA profiles for forensic and policing use in the EU, established by the so-called Prüm Decisions ${ }^{2}$. Within the broad framework of a project to create an area of freedom, security, and justice, the Prüm Decisions compel Member States to create the conditions for the reciprocal automated exchange of DNA profiles that will enable stepping up cross-border cooperation, particularly in fighting terrorism and crossborder crime.

As mentioned earlier, the present volume is based on long-term study of the societal, cultural, political, and ethical implications of the so-called Prüm system. This research followed a qualitative and multi-method approach, based on the integrated and coordinated combination of three main research techniques: first, the conduction of semi-structured interviews with different 
professionals whose activity is related with applying forensic genetics to criminal investigation, as well as other stakeholders directly involved with these issues. Among the research techniques used in the "Exchange Project," interviewing was the method responsible for generating the largest bulk of empirical information: in total, 124 interviews were conducted with 140 interviewees from 25 different EU countries ${ }^{3}$. Second, this study relied on document analysis from several relevant sources, from legislation and official documents to scientific literature in the domain of forensic genetics. Finally, the "Exchange Project" involved direct and participant observation in scientific meetings and other relevant situated contexts (such as laboratories and other workplaces of interviewees engaged in the transnational exchange of information occurring within the scope of police and judicial cooperation).

Throughout this study, we sought a systematic harmonization between the principles of grounded theory and discourse analysis. The grounded theory approach developed by Barney G. Glaser and Anselm Strauss (1967) was designed to help researchers to elicit and analyze qualitative data to identify important categories, with the aim of generating ideas and theory "grounded" in the data. The further development of this approach is particularly welladjusted to discovery-oriented research in areas that are under-theorized (Bryant \& Charmaz, 2007; Charmaz, 2006, 2016; Clarke, 2005). Based on this approach, new topics and concepts were gradually incorporated into interviews and adapted, depending either on the social actors' specific positioning as it emerged from the narratives constructed in the course of interviews or on interests that we were able to anticipate considering each participant's social and professional position (Bryant \& Charmaz, 2007).

As the themes, topics, and categories of analysis repeated themselves, revealing their differences and similarities, we moved on to a second level of qualitative analysis, guided by the principles of discourse analysis located in a social constructionist paradigm (Berger \& Luckmann, 1996; Hacking, 2000; Sismondo, 2003). As explained by Charlotte Burck, in a work that summarizes the different methodologies used in social sciences which are particularly useful for research on subjective experiences and meanings, discourse analysis allows capturing and understanding how the discourses and interpretive repertoires of individuals provide accounts of themselves and their social worlds (Burck, 2005). In this book, therefore, discourse is regarded as a set of meanings, metaphors, representations, images and stories - and in some cases, as an institutionalized use of language - which produces particular versions of events and the social world (Burck, 2005).

\section{A European identity? "Utopian" and "dystopian" visions and expectations}

As explained in our earlier description of the empirical study that inspired our study, this volume's underlying research theme explores the close links between a highly-specialized field of expert scientific knowledge - forensic 
genetics - and the fight against crime and terrorism in the EU. However, the approach presented in this book goes far beyond what this starting point might lead one to assume and anticipate. First of all, because this book questions the existence of a unique mode of genetic surveillance and governance of crime. This volume, therefore, is by no means limited to genetic surveillance in the EU security policy arenas. We share the interrogation formulated by Sheila Jasanoff, in her work about biotechnology politics and policy in Europe and the US, where the author compares the triumphs and tribulations of late capitalistic technological democracies by asking whether it is even possible to talk about a European vision, or whether we are dealing instead with a "multiply imagined community" (Jasanoff, 2005). In Jasanoff's words:

Europe in particular is a multiply imagined community in the minds of the many actors who are struggling to institutionalize their particular versions of Europe, and how far national specificities should become submerged in a single European nationhood - economically, politically, ethically - remains far from settled.

(Jasanoff, 2005, p. 10)

The crucial questions, therefore, might be put thus: what visions and expectations are enacted by genetic surveillance in the governance of crime in the European security policy arena? How are genetic technologies and forensic DNA databases imagined in Europe? How is Europe imagined in the context of DNA data use in the fight against crime and terrorism? How does the European imaginary translate into different national contexts? How do the different stakeholders ascribe meanings to genetic surveillance in the governance of crime, and how do these views and expectations contribute to the making and unmaking of an (un)settled European identity?

To answer these research questions, the concept of sociotechnical imaginaries, proposed by Sheila Jasanoff and Sang-Hyun Kim (2009, 2015), is particularly useful. In their words, sociotechnical imaginaries are "collectively imagined forms of social life and social order reflected in the design and fulfillment of nation-specific scientific and/or technological projects" (Jasanoff \& Kim, 2009, p. 120). The authors compare imaginaries to discourses, metaphors and cultural meanings, out of which actors build their policy preferences, drawing on a growing recognition that the capacity to imagine the future is a crucial constitutive element in social and political life. Hence, sociotechnical imaginaries include not only tightly bound belief systems ideologies in a narrow sense - but also policy imaginations containing implicit understandings of what is good or desirable in the social world. Through the lens of the sociotechnical imaginaries we can, therefore, see how genetic surveillance in the governance of crime is imagined within the European policy context, but also how the 'European technological zone' (Barry, 2001, 2006; Mager, 2016) is enacted and infused with meaning in this particular context. 
Throughout this book, the controversies and problematics connected to genetic surveillance in the governance of crime are addressed through the visions and interpretations ascribed by different social actors to their own actions (Weber, 1949). These constructions of meaning - or more simply, these "visions and ideas of people" - frequently correspond to instances of "imagining the future," assessing the present from a utopian or dystopian point of view. The term "vision" is, therefore, largely overlapped by the notion of "expectation," and on many occasions we will use both terms interchangeably. However, we will also use the term "vision" to underline the emphasis on its enacting and subjectively normative character (Borup et al., 2006, p. 286), while using "expectation" to refer directly to technological advances, since it can be more specifically applied to representations of future technological situations and capabilities (Borup et al., 2006, p. 286).

Visions and expectations can be seen as fundamentally "generative," in the sense that they guide activities, provide structure and legitimation, define roles, and clarify boundaries of knowledge and action, while tending to have a persistent future oriented-nature, insofar as they shape some shared conception of what to expect and how to prepare for opportunities and risks (Borup et al., 2006; see also Brown \& Michael, 2003; and more recently, Tutton, 2020). Our focus on the visions and expectations for forensic genetic technologies and their potential and capabilities in the governance of crime is mainly centered on those construed and performed by forensic geneticists.

However, the category of "forensic geneticist" is itself highly heterogeneous, serving as a blanket term that includes both forensic geneticists who work in university departments of forensic sciences, as well as forensic geneticists working in forensic laboratories that provide services to courts or government police agencies (Cole, 2013).

The prevalence of forensic geneticists' visions and expectations resulted from the contingencies of the empirical study guiding this book - originally centered on exploring and understanding this specific group's social representations - and not from any kind of presumption that forensic geneticists' views and interpretations are more significant or in any way should be given greater visibility. In fact, the constructivist and interpretative paradigm followed in this book (Law, 1991, 2008; Bijker \& Law, 1992; Pickering, 1992) leads us to consider that the social construction of reality implies the intervention of multiple social actors with a diversity of situated interests, values, agendas and perspectives.

Nevertheless, we must bear in mind the existence of a common and shared "social repertoire" of views and expectations (Konrad, 2006; Quinlan, 2020), supported within a widely shared cultural and social stock, which provides meaning to genetic surveillance and the governance of crime and which might be either reproduced and reinforced or questioned and challenged.

In order to provide the reader with the context for the multiple views, both collective as well as those "specific" to certain groups of actors (whether reflecting utopian, dystopian or a complex and fluid combination of both views), and their role in the construction of the performativity of genetic surveillance in the governance of crime, we believe that it is important to consider 
two dimensions of analysis: on the one hand, the visions and expectations in themselves; on the other hand, the material conditions for the actualization of genetic surveillance. The means through which the uses of genetic technology are materialized - in terms of legislation, scientific development and technological infrastructures and institutional and operative conditions (Johnson, Williams, \& Martin, 2003) - will create the context or setting for the views of a specific group, or those that have the power and resilience to emerge collectively, to become more effective in their practical and symbolic consequences.

\section{The structure of the book}

This book comprises eight chapters: besides the present introduction, where we introduce the reader to the main themes and topics debated in the literature about social sciences approaches to forensic genetics in the governance of crime, the book entails seven other chapters that address a diversity of empirical cases illustrating the prevailing trends of contemporary genetic surveillance and its social, cultural, and political implications in Europe and beyond. The second chapter of this book presents a historical and sociological analysis of the evolution of forensic genetics applied to governance of crime, from the late 1980s until the present. The manifold developments in DNA profiling techniques, as well as the creation and expansion of forensic DNA databases, are illustrated with empirical examples of the uses given to forensic genetic techniques in different parts of the world. The numerous social, ethical and political concerns and contentions pertaining to forensic DNA profiling and databasing are situated at the intersection between science, civic and human rights, and relationships between citizens and the state. In this chapter we outline how such relations are historically and culturally contingent and situated in local and national contexts. That is, how the benefits or risks of technology for social order are never obvious, ubiquitous, and unquestionable.

We focus on providing a context which might help the reader to understand that, while there is a global trend of forensic genetics' expansion across many regions of the world, this does not occlude the fact that different societies and cultures present diverse histories of technology and governance. The examples presented clearly show that DNA profiling and databasing technologies are, paraphrasing Sheila Jasanoff, technologies of social control, imagined and produced in the West for use in the rest of the world, which are never ethically or politically neutral (Jasanoff, 2010).

In order to substantiate the multiplicity, intricacy and fluidity of the social, ethical and political constellations prompted by forms of genetic surveillance in the governance of crime, we appeal to diversified geographical and political contexts: we begin by presenting a case from mainland China which is particularly revealing of the trends of maximum surveillance society and religious and ethnic minority stigmatization. Then we go on to highlight the diversity of trends and trajectories of forensic technologies and genetic databases in the 
United States and, above all, in Europe, referring to examples such as the United Kingdom, France, Germany, Poland, and Portugal. This brief overview of national cases demonstrates how these technologies' different trajectories are concomitantly accompanied by histories of science and technology governance, evolutions of securitarian policies and political traditions.

The historical and sociological systematization of the social and political tensions that derive from the use of forensic genetic technologies in different regions around the world, as well as the revelation of the multiplicity and complexity of circumstances in different national and political contexts, serve in this chapter to delineate and clarify this book's scope and ambition. Our aim is to make a qualitative enhancement of the analytical lens that has characterized the literature from the social sciences on the theme of genetics in its application to criminal justice. The overwhelming majority of this production places an emphasis on the intersections between science, human rights, and civil liberties on the one hand, and the controversies associated with the increasing surveillance of citizens on the other. This book's second chapter, while incorporating these concerns and controversies, also seeks to reach beyond them. We seek to provide a theoretical and empirically grounded perspective that could contribute toward a broader social theory on the genetization of society, able to understand the modes of conceiving the human and the interrelations between justice and science during what might be described as a post-DNA era.

The third chapter focuses on the empirical subject that served as the starting point for our study: the sociological approach to a transnational pan-European system of automated DNA profile exchange between EU Member States, known as the Prüm System. Prüm is exemplary of how public discourse has seized on the prevention and investigation of cross-border crime and terrorism as the main driving force and justification for the proliferation of surveillance systems. Our main goal in this chapter is to map and comprehend the workings behind Prüm's operations. The ostentatiously expansive nature of surveillance promoted through DNA transnational exchange, should not compel us to limit our analysis to the political, ethical and human rights aspects implied in Prüm. Instead, we address the complexity of epistemic cultures, identities, interests and power relations that characterize the actions and expectations of the two distinct professional groups directly involved in the operations of the Prüm system: by one side, the National Contact Points conducting laboratory work, working with DNA profiling and DNA databases; by the other side, the National Contact Points working within law enforcement international cooperation forces. These two professional groups contribute to the visions and expectations regarding the role of genetic surveillance in the governance of crime in Europe, through a combination of both collective and shared beliefs. More particularly, they outline the capacity and value of the transnational exchange of DNA data to support the investigation of crossborder crime and terrorism, while at the same time, maintaining their specific professional positioning and protecting their particular expertise.

Thus, this third chapter illustrates how the increasing expansion of genetic surveillance's reach and scope, is constructed, performed and legitimized 
through an "interpretative flexibility" (Konrad, 2006) which, according to Kornelia Konrad, governs how various actors relate, both with their own expectations as with others'. As we argue in this chapter, interpretative flexibility operates as a two-sided phenomenon: on one side, the collective expectations for the Prüm system summon a large number of highly heterogeneous actors, based on perceptions of the benefits of expanding the system of cooperation - speeding up exchange of DNA data and valuable information for criminal investigation, increasing accuracy and reliability. On the flipside, expectations are strategically distributed according to the specific positioning of actors and their particular situatedness. This interpretative flexibility also sets the ground for nurturing what we have elsewhere described (with our colleague Nina Amelung) a combined culture of "European integration" and "hidden disintegration" (Amelung et al., 2020). The Prüm system enacts an idea of "European integration," believed to be achievable through the harmonization of scientific and technical procedures between laboratories and police forces in different countries. Conversely, "hidden disintegration" derives from the fact that not only were the mandatory elements of the Prüm Decisions politically enforced without taking the differences between EU countries into consideration, but also neglected the different professional epistemic cultures involved in the operation of DNA data exchange.

The fourth chapter of the book is dedicated to forensic genetics technologies and genetic surveillance specifically in European post-communist countries, presenting how a particular idea of Europe is construed and thus laying bare a set of tensions that underlie the image of a "European Identity." Forensic genetics in the so-called Central and Eastern Europe (CEE) countries is a theme that has thus far remained largely unexplored by social scientists. We explore how the meanings attached to forensic genetic technologies in these countries are influenced by memories of their collective past, namely the legacy of totalitarian communist regimes. At the same time, this chapter also seeks to demonstrate the multiplicity of European imagined communities (Jasanoff, 2005) showing how the power to institutionalize a specific vision of Europe might be partly inaccessible to CEE countries.

Although the expansion of genetic surveillance is seen as a path for enacting and performing and "European way" (Barry, 2001), this chapter also evinces the impossibility of a single European nationhood and the continuous shaping and reshaping of European integration and disintegration (Amelung et al., 2020). It illustrates how fundamentally different visions and values rooted in different historical experiences, socio-political traditions, cultures, and ideological foundations, all participate in the co-production of genetic surveillance, governance of crime, and the making and unmaking of a European identity (Mager, 2016). This also suggests that the visions and expectations for the role of genetic surveillance in the governance of crime are shaped by - and concomitant with - unstable European values, which in turn are not separable from either European politics or convoluted transitions from authoritarian regimes to democracy. 
In the fifth chapter of this volume, we turn the focus to familial searching a technology that detects genetic relatedness and is used to identify criminal suspects and/or identify missing persons through their connection with relatives whose profiles are included in forensic DNA databases. More specifically, we move away from traditional approaches that reflect solely upon the uses of familial searching in criminal investigations, highlighting its ethical, social, and operational challenges, as a means to explore how this technology is situated, within the European context, at the intersection of two distinct but related rationales: control and care. That is, by emphasizing how familial searching might be either mobilized to expand suspicion by assisting criminal investigations, and/or to provide historical reparation for collective trauma by supporting the identification of the missing (Granja \& Machado, 2019).

Familial searching is subjected to a diversity of regulatory frameworks around Europe that oscillate between control and care. While in some countries its use is solely restricted to assisting criminal investigations, in others there is a more concrete focus on how this technology might assist the identification of "the missing" (Smith, 2017). The latter situation is more evident in countries with a recent history of repression under totalitarian regimes and substantially affected by the disappearance of its people (Colls, 2016), where DNA identification in the field of missing persons tends to represent a facilitating mechanism of reconstitution. Different uses of DNA-identification, namely control and care, are thus being amalgamated into a single political project, aimed at expanding genetic surveillance. This trend is not, however, restricted to innovative technologies such as familial searching. The move a towards a security - and disaster focused identification grounded in global law enforcement, is also clearly patent in pre-established architectures of crime control, such as Prüm system, which increasingly incorporates and exchanges data related to missing persons.

The sixth chapter deals with the expansion of genetic informativity, by looking at two cases of technologies that embody what we shall call a postDNA era, where frictions between non-coding and coding DNA are increasingly relevant. The cases in point are Forensic DNA Phenotyping (FDP) and Next Generation Sequencing (NGS) technologies. Based on interviews with forensic geneticists, in this chapter we explore how expectations for innovations in forensic genetics might profoundly change contemporary views about (diverging) principles of legitimacy (or lack thereof) regarding the use of genetic data in criminal investigation, while opening up new paths for reconsidering what criminal identification might consist of, and what the governance of forensic genetics should allow it to investigate and intend it for.

In relation to FDP - that is, the constellation of techniques used to infer physical features, such as eye, skin, and hair color, as well as information about biogeographic ancestry - forensic geneticists point out FDP's added valued to criminal investigations, while also underlining its epistemic risk, investigative character and selective application in criminal cases considered serious or otherwise difficult to solve. Regarding NGS, forensic geneticists are divided between portraying it as a revolution, and expressing a deep skepticism about its 
added value for routine case work. Such variable positions are influenced by forensic geneticists' diverse locations within a developing network of relationships of innovation, namely their position in terms of access to resources or the type of work conducted, which might either be more focused on research science or on forensic applied science.

This chapter clearly shows that, regardless of each technology's specificities, the so-called post-DNA era is inevitably marked by attempts to protect forensic science's credibility and autonomy, by engaging with "anticipatory governance" strategies (Tutton, 2011; Wienroth, 2018) that directly address issues of reliability, utility and legitimacy (Wienroth, 2020). One other feature of the post-DNA era is the increasing importance of a growing market interested in the commercialization of science and forensic equipment (Granja, 2020). This is also particularly visible in one other technology, briefly addressed in this chapter: long-range familial searches conducted in recreational DNA databases where citizens voluntarily upload genetic information to know more about their health and/or ancestry. The expansion of genetic informativity, therefore, couples the ethically sustained debate about enrolling human appearance, "race," and medical and family information in the field of forensic genetics, with the compounding tensions and controversies between scientific imperatives, judicial priorities, and commercial interests.

Chapter seven operates a shift in perspective, from the professionals who are directed involved in the development and/or application of genetic technologies, such as National Contact Points of the Prüm system or forensic geneticists seen in previous chapters, to the views of European-based nongovernmental organizations (NGO) representatives concerned and critically engaged with the development of forensic DNA databases and the application of innovative and controversial genetic technologies in the criminal justice system. Within a framework where genetic surveillance is consistently expanding, it is of upmost importance to understand how NGOs' self-definition of their goals and functions, relate to meanings, values and power structures of forensic DNA databases and innovative forensic genetic technologies.

The main goals of NGOs are concerned with a critique of how genetic surveillance's expansion promotes a rebalance power which threatens the rights of the "biological citizen." Other goals focus on informing the public about science and technology innovations and promoting the adoption of a responsible approach to genetic data. Europe, however, presents a highly differentiated landscape in terms of NGO presence and visibility, highly influenced by the broader historical, social, political, and economic principles embedded in each country's specific contexts and infrastructures. This implies that NGOs' visibility and range of action is highly contingent on each country's specific traditions, namely in terms of transparency and accountability policies while, at the same time, they carve out spaces of public visibility and legitimate vindication.

The concluding chapter provides the reader with an overview of our main theoretical advances in the specific field of social studies of science and 
technology, and reveals the most inspiring empirical findings, while also opening up new paths for future research on the role of forensic genetics in its multiple forms and diverse performances of surveillance in the governance of crime. Forensic genetic technologies have emerged at different points in time and space, but they have all consistently endured: currently they co-exist around the globe, and their profound cultural and ethical implications are foreseeable in the near future. In our concluding remarks we make clear how the presence of forensic genetics in different social and political contexts across Europe and beyond, demands an urgent and constant discussion about the kind of governance and modes of public engagement to which democratic societies require and should aspire.

Our ambition in this book clearly exceeds the context of science production: our work aims to investigate how values and expectations constructed by varied social actors and diverse stakeholders influence the way science and technology in the domain of forensic genetics become enmeshed in performing and producing diverse visions of governance of crime, at a variety of scales and affecting diverse publics. One relevant highlight of this book is undoubtedly to develop an in-depth understanding of the values, judgements, power relations, and agendas incorporated in the hopes and promises, as well as in the fears and anxieties regarding genetic surveillance in the governance of crime in Europe and elsewhere.

\section{Notes}

1 More information can be found here: http://exchange.ics.uminho.pt (last accessed 15 January 2020).

2 The Prüm Convention was signed in 2005 by Austria, Belgium, France, Germany, Luxembourg, the Netherlands, and Spain in the town of Prüm, Germany. The Convention was subsequently adopted into European Union Law (Decisions 2008/ 615/JHA and 2008/616/JHA), under the so-called Prüm Decisions that establish the automated exchange of DNA, fingerprint and vehicle registration data among the EU Member States for the purpose of fighting crime and terrorism.

3 The interviews were conducted by the authors and other members of the Exchange project between 2015 and 2019. The authors are deeply indebted to Nina Amelung, Sheila Khan, Filipa Queirós, Sara Matos, and Filipe Santos for their participation and collaboration in the collection of data. The main underlying goal of the interviews was to capture the diverse embedded meanings and interpretations that illustrate a corresponding variety of perspectives on the social, cultural, ethical, regulatory and political dimensions involved in the use of DNA technologies with forensic purposes across the EU. In terms of the sampling methods used in the selection of interviewees, we followed three different strategies: we started by mapping out the group of professionals involved in the Prüm system's National Contact Points, searching in the public listing available in the documents of the "Working Party on Information Exchange and Data Protection" (Council of the European Union, 2015, 2017), as well as through contacts with privileged informants. This enquiry led to 47 interviews. We also conducted interviews with members of the European forensic genetic community, whom we reached through the lists of members of professional organizations and international research networks. The selection of forensic geneticists was also based on the literature produced by authors in 
the field of forensic genetics. Finally, we conducted 11 interviews with non-government organization representatives working in the areas of human rights and science (both in the specific domain of genetics as in broader fields, such as "surveillance") in five countries selected as case studies (Germany, Netherlands, Poland, Portugal, and UK). The interview scripts covered a wide array of topics: the main operational, scientific and ethical challenges posed by the Prüm system's implementation; expectations for the development and innovation in DNA technologies, namely the development of technologies considered controversial - such as FDP, familial searching, and NGS -, as well as expectations regarding the impact of the private sector's growing presence. Another topic broached in the interviews covered the questions of public involvement, accountability and transparency in the governance of forensic DNA databasing, on issues such as the communication of science in courts and with citizens. This book focuses on 107 interviews selected from a total of 124 interviews available in the scope of this study. We thus excluded interviews with stakeholders from the five case studies (Germany, Netherlands, Poland, Portugal, and UK), namely: supervisory and regulatory entities, university professors and researchers, legislators, criminal investigation agencies, private companies, and the media. Most interviews were conducted face-to-face, at the interviewees' workplace, following the protocols of informed consent approved by the European Research Council. Before the interviews, all participants signed a written informed consent document and agreed to be audio-recorded. All interviews, except two, were digitally recorded and transcribed verbatim by professional services. The interviews were conducted in a language familiar to interviewees and interviewers alike, mostly in English (87), but also in Portuguese (28), German (six), and Spanish (three). The interviews in German and Spanish were translated to English by external professionals. These translations sought as far as possible to thoroughly respect the content and meanings conveyed by interviewees.

\section{References}

Amelung, N., Granja, R., \& Machado, H. (2020). Modes of Bio-Bordering: The Hidden (Dis)integration of Europe (1st ed.). London: Palgrave Macmillan. https:// doi.org/10.1007/978-981-15-8183-0.

Amorim, A. \& Pinto, N. (2018). Big data in forensic genetics. Forensic Science International: Genetics, 37, 102-105. https://doi.org/10.1016/J.FSIGEN.2018.08.001.

Aronson, J. (2007). Genetic Witness: Science, Law, and Controversy in the Making of DNA Profiling. Piscataway, NJ: Rutgers University Press.

Barry, A. (2001). Political Machines: Governing a Technological Society. London: The Athlone Press. http://dx.doi.org/10.5040/9781474213110.

Barry, A. (2006). Technological zones. European Journal of Social Theory, 9(2), 239253. https://doi.org/10.1177/1368431006063343.

Beraldo, D. \& Milan, S. (2019). From data politics to the contentious politics of data. Big Data \& Society, 6(2), 1-11. https://doi.org/10.1177/2053951719885967.

Berger, P.L. \& Luckmann, T. (1996). The Social Construction of Reality: A Treatise in the Sociology of Knowledge. New York: Doubleday.

Bijker, W. \& Law, J. (Eds). (1992). Shaping Technology/Building Society. Studies in Sociotechnical Change. Cambridge: MIT Press.

Borup, M., Brown, N., Konrad, K., \& Van Lente, H. (2006). The sociology of expectations in science and technology. Technology Analysis \& Strategic Management, 18 (3/4), 285-298. https://doi.org/10.1080/09537320600777002. 
Brown, N. \& Michael, M. (2003). A sociology of expectations: retrospecting prospects and prospecting retrospects. Technology Analysis \& Strategic Management, 15(1), 3-18. https://doi.org/10.1080/0953732032000046024.

Bryant, A. \& Charmaz, K. (Eds.). (2007). The SAGE Handbook of Grounded Theory. Thousand Oaks: SAGE Publications.

Burck, C. (2005). Comparing qualitative research methodologies for systemic research: the use of grounded theory, discourse analysis and narrative analysis. Journal of Family Therapy, 27(3), 237-262. https://doi.org/10.1111/j.1467-6427.2005.00314.x.

Charmaz, K. (2006). Constructing Grounded Theory: A Practical Guide Through Qualitative Analysis. Thousand Oaks: SAGE Publications.

Charmaz, K. (2016). The power of constructivist grounded theory for critical inquiry. Qualitative Inquiry, 23(1), 34 45. https://doi.org/10.1177/1077800416657105.

Clarke, A. (2005). Situational Analysis: Grounded Theory After The Postmodern Turn. Thousand Oaks: SAGE Publications.

Cole, S. (2001). Suspect Identities: A History of Fingerprinting and Criminal Identification. Cambridge: Harvard University Press.

Cole, S. (2013). Forensic culture as epistemic culture: the sociology of forensic science. Studies in History and Philosophy of Biological and Biomedical Sciences, 44(1), 3646. https://doi.org/10.1016/j.shpsc.2012.09.003.

Cole, S. (2018). Individual and collective identification in contemporary forensics. BioSocieties, 15(3), 350-375. https://doi.org/10.1057/s41292-018-0142-z.

Colls, C.S. (2016). 'Earth Conceal Not My Blood': Forensic and Archaeological Approaches to Locating the Remains of Holocaust Victims. In J.-M. Dreyfus, \& É. Anstett (Eds.), Human Remains in Society: Curation and Exhibition in the Aftermath of Genocide and Mass-violence (pp. 163-196). Manchester: Manchester University Press.

Council of the European Union. (2015). Working Party on Information Exchange and Data Protection (DAPIX). Brussels.

Council of the European Union. (2017). Working Party on Information Exchange and Data Protection (DAPIX) - Prüm/DNA Data Exchange Evaluation of United Kingdom (UK). Brussels.

Derksen, L. (2010). Micro/macro translations: the production of new social structures in the case of DNA profiling. Sociological Inquiry, 80(2), 214-240. https://doi.org/ 10.1111/j.1475-682X.2010.00328.x.

EU Council. (2008a). Council Decision 2008/615/JHA of 23 June 2008 on the stepping up of cross-border cooperation, Particularly in combating terrorism and crossborder crime. Official Journal of the European Union. Official Journal of the European Union. Brussels.

EU Council. (2008b). Council Decision 2008/616/JHA of 23 June 2008 on the implementation of decision $2008 / 615 /$ jha on the stepping up of cross-border cooperation, particularly in combating terrorism and cross-border crime. Official Journal of the European Union. Brussels.

Glaser, B.G. \& Strauss, A.L. (1967). The Discovery of Grounded Theory: Strategies for Qualitative Research. Berlin: Aldine de Gruyter.

Granja, R. (2020). Long-range familial searches in recreational DNA databases: expansion of affected populations, the participatory turn, and the co-production of biovalue. New Genetics and Society, 1-22. https://doi.org/10.1080/14636778.2020.1853515.

Granja, R. \& Machado, H. (2019). Ethical controversies of familial searching: the views of stakeholders in the United Kingdom and in Poland. Science, Technology, \& Human Values, 44(6), 1068-1092. https://doi.org/10.1177/0162243919828219. 
Granja, R. \& Machado, H. (2020). Forensic DNA phenotyping and its politics of legitimation and contestation: views of forensic geneticists in Europe. Social Studies of Science, 1-19. https://doi.org/10.1177/0306312720945033.

Hacking, I. (2000). The Social Construction of What?Cambridge: Harvard University Press.

Hacking, I. (2006). Genetics, biosocial groups \& the future of identity. Daedalus, 135 (4), 81-95. www.mitpressjournals.org/doi/pdf/10.1162/daed.2006.135.4.81.

Hindmarsh, R. \& Prainsack, B. (Eds). (2010). Genetic Suspects: Global Governance of Forensic DNA Profiling and Databasing. Cambridge: Cambridge University Press.

Hopman, R. \& M'charek, A. (2020). Facing the unknown suspect: forensic DNA phenotyping and the oscillation between the individual and the collective. BioSocieties, 15, 438-462. https://doi.org/10.1057/s41292-020-00190-9.

Jasanoff, S. (2005). Designs on Nature: Science and Democracy in Europe and The United States. Princeton, NJ: Princeton University Press.

Jasanoff, S. (2010). Foreword. In R. Hindmarsh \& B. Prainsack (Eds), Genetic Suspects: Global Governance of Forensic DNA Profiling and Databasing (pp. xix-xxiv). Cambridge: Cambridge University Press.

Jasanoff, S. \& Kim, S.-H. (Eds.). (2015). Dreamscapes of Modernity: Sociotechnical Imaginaries and the Fabrication of Power. Chicago and London: University of California Press. https://doi.org/10.7208/chicago/9780226276663.001.0001.

Jasanoff, S. \& Kim, S.-H. (2009). Containing the atom: sociotechnical imaginaries and nuclear power in the United States and South Korea. Minerva, 47(2), 119-146. http s://doi.org/10.1007/s11024-009-9124-4.

Jeffreys, A.J., Wilson, V., \& Theint, S.L. (1985). Individual-specific "fingerprints" of human DNA. Nature, 316(4), 76-79.

Johnson, P., Williams, R., \& Martin, P. (2003). Genetics and forensics: making the national DNA database. Science Studies, 16(2), 22-37. www.pubmedcentral.nih. gov/articlerender.fcgi?artid=PMC1351151.

Kennett, D. (2019). Using genetic genealogy databases in missing persons cases and to develop suspect leads in violent crimes. Forensic Science International, 301, 107117. https://doi.org/10.1016/j.forsciint.2019.05.016.

Konrad, K. (2006). The social dynamics of expectations: the interaction of collective and actor-specific expectations on electronic commerce and interactive television. Technology Analysis \& Strategic Management, 18(3-4),429-444. https://doi.org/10. 1080/09537320600777192.

Law, J. (Ed.). (1991). A Sociology of Monsters: Essays on Power, Technology and Domination. London: Routledge.

Law, J. (2008). On sociology and STS. Sociological Review, 56(4), 623-649. https://doi. org/10.1111/j.1467-954X.2008.00808.x.

Lawless, C. (2012). The low template DNA profiling controversy: biolegality and boundary work among forensic scientists. Social Studies of Science, 43(2), 191-214. https://doi.org/10.1177/0306312712465665.

Lynch, M., Cole, S., McNally, R., \& Jordan, K. (2008). Truth Machine: The Contentious History of DNA Fingerprinting. Chicago: University of Chicago Press. http s://doi.org/10.1017/CBO9781107415324.004.

Lynch, M. \& McNally, R. (2009). Forensic DNA Databases: The Co-production of Law and Surveillance Technology. In P. Atkinson, P. Glasner, \& M. Lock (Eds.), Handbook of Genetics and Society: Mapping the New Genomics Era (pp. 283-301). London: Routledge. 


\section{Genetic Surveillance and Crime Control}

Lyon, D. (2001). Surveillance Society: Monitoring Everyday Life. Milton Keynes: Open University Press.

Lyon, D. (2002). Surveillance as Social Sorting: Privacy, Risk and Automated Discrimination. Hoboken: Taylor \& Francis.

M'charek, A. (2020). Tentacular faces: race and the return of the phenotype in forensic identification. American Anthropologist, 122(2), 369-380. https://doi.org/10. 1111/aman.13385.

M'charek, A. \& Wade, P. (2020). Doing the individual and the collective in forensic genetics: governance, race and restitution. BioSocieties, 15(3), 317-328. https://doi. org/10.1057/s41292-020-00193-6.

Machado, H., \& Granja, R. (2018). Ethics in transnational forensic DNA data exchange in the EU: constructing boundaries and managing controversies. Science as Culture, 27(2), 242-264. https://doi.org/10.1080/09505431.2018.1425385.

Machado, H. \& Granja, R. (2020). Forensic Genetics in the Governance of Crime. Singapore: Springer Singapore. https://doi.org/10.1007/978-981-15-2429-5.

Mager, A. (2016). Search engine imaginary: visions and values in the co-production of search technology and Europe. Social Studies of Science, 47(2), 240-262. https://doi. org/10.1177/0306312716671433.

Marx, G.T. (2002). What's new about the "new surveillance"? Classifying for change and continuity. Surveillance \& Society, 1(1), 9-29. https://doi.org/10.24908/ss.v1i1.3391.

McCartney, C. (2014). Trans-national Exchange of Forensic (Bio)information. In G. Bruinsma \& D. Weisburd (Eds.), Emerging Issues in International Forensic Bioinformation Exchange (5302-5313). New York: Springer. https://doi.org/10.1007/ 978-1-4614-5690-2.

Nelkin, D. \& Lindee, M.S. (1995). The DNA Mystique: The Gene as a Cultural Icon. New York: W.H. Freeman.

Pickering, A. (Ed.). (1992). Science as Practice and Culture. Chicago: University of Chicago Press.

Prainsack, B. \& Toom, V. (2010). The Prüm regime. Situated dis/empowerment in transnational DNA profile exchange. British Journal of Criminology, 50(6), 11171135. https://doi.org/10.1093/bjc/azq055.

Prainsack, B. \& Toom, V. (2013). Performing the union: the Prüm decision and the european dream. Studies in History and Philosophy of Biological and Biomedical Sciences, 44(1), 71-79. https://doi.org/10.1016/j.shpsc.2012.09.009.

Quinlan, A. (2020). The rape kit's promise: techno-optimism in the fight against the backlog. Science as Culture, 1-25. https://doi.org/10.1080/09505431.2020.1846696.

Rabinow, P. (1996). Essays on the Anthropology of Reason. Princeton: Princeton University Press. https://doi.org/10.2307/1576556.

Reed, K. \& Syndercombe-Court, D. (2016). A comparative audit of legislative frameworks within the European Union for the collection, retention and use of forensic DNA profiles. EUROFORGEN - NoE. London. www.euroforgen.eu/fileadmin/web sites/euroforgen/images/Dissemination_Documents/WP4/Reed_and_Syndercombe_ Court_2016_Legal_Audit.pdf.

Samuel, G. \& Prainsack, B. (2018). Forensic DNA phenotyping in Europe: views "on the ground" from those who have a professional stake in the technology. New Genetics and Society, 38(2), 119-141. https://doi.org/10.1080/14636778.2018.1549984.

Santos, F., Machado, H., \& Silva, S. (2013). Forensic DNA databases in european countries: is size linked to performance? Life Sciences, Society and Policy, 9(12), 113. https://doi.org/10.1186/2195-7819-9-12. 
Sismondo, S. (2003). The Social Construction of Scientific and Technical Realities. In S. Sismondo (Ed.), An Introduction to Science and Technology (1st ed.), 51-64. Hoboken: Blackwell Publishers. www.f.waseda.jp/sidoli/Sismondo_Introduction_ STS_6.pdf.

Skinner, D. (2018). Race, racism and identification in the era of technosecurity. Science as Culture, 29(1), 77-99. https://doi.org/10.1080/09505431.2018.1523887.

Smith, L.A. (2016). Identifying democracy: citizenship, DNA, and identity in postdictatorship Argentina. Science, Technology, \& Human Values, 41(6), 1037-1062. https://doi.org/10.1177/0162243916658708.

Smith, L.A. (2017). The missing, the martyred and the disappeared: global networks, technical intensification and the end of human rights genetics. Social Studies of Science, 47(3), 398-416. https://doi.org/10.1177/0306312716678489.

Tutton, R. (2011). Promising pessimism: reading the futures to be avoided in biotech. Social Studies of Science, 41(3), 411-429. https://doi.org/10.1177/0306312710397398.

Tutton, R. (2020). Sociotechnical imaginaries and techno-optimism: examining outer space utopias of Silicon Valley. Science as Culture, 1-24. https://doi.org/10.1080/ 09505431.2020 .1841151$.

Van Der Ploeg, I. (2005). The Machine-readable Body. Essays on Biometrics and the Information of the Body. Maastricht: Shaker Publishing B.V.

Weber, M. (1949). Methodology of the Social Sciences. Glencoe: Free Press.

Wienroth, M. (2018). Governing anticipatory technology practices. Forensic DNA phenotyping and the forensic genetics community in Europe. New Genetics and Society, 37(2), 137-152. https://doi.org/10.1080/14636778.2018.1469975.

Wienroth, M. (2020). Value beyond scientific validity: let's RULE (Reliability, Utility, LEgitimacy). Journal of Responsible Innovation, 7(1), 92-103. https://doi.org/10. 1080/23299460.2020.1835152.

Williams, R. (2010). DNA Databases and the Forensic Imaginary. In R. Hindmarsh \& B. Prainsack (Eds.), Genetic Suspects: Global Governance of DNA Profiling and Databasing (131-152). Cambridge: Cambridge University Press.

Williams, R. \& Johnson, P. (2004). Circuits of surveillance. Surveillance \& Society, 2 (1), 1-14. https://doi.org/10.1901/jaba.2004.2-1.

Williams, R. \& Johnson, P. (2008). Genetic Policing: The Use of DNA in Criminal Investigations. Cullompton: Willan Publishing. http://dx.doi.org/10.4324/9781843925576. 


\title{
2 Forensic Genetics and Genetic Surveillance in Europe
}

\author{
A Historical and Sociological Analysis
}

\section{Introduction}

On February 21, 2019 The New York Times published a piece enticingly titled "China uses DNA to track its people, with the help of American expertise," signed by Sui-Lee Wee, a correspondent in the Beijing bureau who has consistently covered and written about genetic surveillance and health care (Wee, 2019). In this instance, Sui-Lee Wee told the story of Tahir Imin, a 38-yearold Uyghur, who had his blood drawn, his fingerprints collected, his face scanned, and his voice recorded by the authorities in China's Xinjiang region. The Uyghurs are one of China's 55 officially recognized ethnic minorities, and most of them are Muslims. It is estimated that since 2015 over a million Uyghurs have been detained in Xinjiang "re-education camps" set up by the Chinese government administration with the main purpose of ensuring adherence to national ideology. Critics of China's treatment of Uyghurs have accused the Chinese government of promoting a policy of Uyghur ethnocide or cultural genocide in Xinjiang in the 21st century (Ramzy \& Buckley, 2019).

The story about the collection of Imin's biometric data and blood samples points out that authorities called it a "free health check" (Wee, 2019). This journalistic piece also emphasizes that Imin was just one case among millions of people caught up in a vast Chinese campaign of surveillance and oppression in which, according to human rights groups and Uyghur activists, collecting genetic material plays a key role. Finally, The New York Times article also warned that Chinese officials are building a broad nationwide database of DNA samples with the help and support of scientists affiliated to Thermo Fisher, a Massachusetts company that sells equipment for DNA analysis around the world. Human rights groups and Uyghur activists claim that a DNA database of this kind could be used to persecute any Uyghurs who resist such a campaign (Wee, 2019).

In order to establish a comparison with Uyghur DNA, the Chinese officials allegedly relied on genetic material collected from people around the world provided by Dr. Kenneth Kidd, a prominent Yale University geneticist. In the wake of the public scandal that followed the disclosure of this kind of genetic

DOI: $10.4324 / 9780429261435-2$ 
surveillance practice, targeting a specific ethnic and religious minority with the aim of asserting authority and political repression, the private corporation Thermo Fisher declared that it would no longer sell its equipment in Xinjiang, the Chinese region where the Uyghur tracking campaign was mostly taking place. Dr. Kidd also claimed he had been unaware of the use being given to his material and know-how, stating that he had believed Chinese scientists were acting within scientific norms that require informed consent by DNA donors (Wee, 2019, 2020).

This story embodies several issues that help us to put into perspective the problems dealt with in this book, as well as our empirical analysis of the interviews conducted with different stakeholders across Europe. The setting of a dictatorial regime imposed by the Chinese Communist Party comprises political, social, cultural and historical configurations that are substantially distinct from the European empirical setting (or rather, its multiple actualities). Nonetheless, the events narrated in The New York Times article involve a variety of practices, social actors, expectations and relations of power that are found across different settings, whether in dictatorial or democratic societies. Among these, we emphasize the following aspects: the use of genetic surveillance as an instrument of power and its impact on the stigmatization of particular ethnic or racial minorities; state ambitions to build genetic databases for the collection, storage and use of information about its citizens; the role of private corporations in supporting the development and expansion of databases and forensic genetic technologies; and the permeability of the boundaries that distinguish between the use of genetic databases designed specifically for criminal identification purposes and the use of non-criminal genetic databases.

According to Andra le Roux-Kemp (2018), by March 31, 2012 China's database contained more than 13 million DNA profiles, making it the largest forensic DNA database in the world, in absolute numbers (Interpol, 2016). The lack of any legislative framework or regulatory guidelines for its operation and the fact that DNA databases in China are operated by notoriously repressive police forces, together with the fact that criminal courts and prosecutors are dependent on the Communist party, raises many questions regarding the uses of criminal DNA databases (Le Roux-Kemp, 2018). But while the high levels of mass surveillance implemented by the Chinese Government are the object of wide controversy and international concern from a human rights' perspective (Leibold \& Emile, 2020; Richardson, 2017), we must point out that the amplification of genetic surveillance is not the prerogative of dictatorial regimes. No doubt, a wide chasm separates Greater China and Europe in terms of human rights. For example, in democratic political systems, police forces - as an executive branch of the government have a duty to serve rather than threaten the people (Hufnagel, 2017). In spite of this general framework, however, we also should note, as suggested in a previous work with our colleague Nina Amelung (Amelung, Granja \& Machado, 2020), that the European Union (EU) does not possess a common 
and unified human rights' regime. Consequently, our approach is mindful of the differences between EU Member States, not only in terms of human rights practices, but also with regard to technical, scientific, operational and other legal practices linked to legitimacy claims that are rationalized within the rhetoric of democracy (Amelung et al., 2020).

One of the most emblematic cases of a maximum surveillance society in Europe is the United Kingdom (Norris \& Armstrong, 1999). It was not only the first country in the world to create a DNA database for criminal identification purposes (in 1995), but also to develop pioneering practices in the collection of biometric data from its citizens, immigrant populations, and asylum seekers (Amankwaa \& McCartney, 2019; Tutton, Hauskeller \& Sturdy, 2014). Established in 1995, the United Kingdom's National Criminal Intelligence DNA Database (NDNAD) is believed to be the world's oldest national forensic DNA database (Downey, Stephens \& Flaherty, 2012; Johnson \& Williams, 2007). On March 31, 2020, the number of DNA profiles contained in the NDNAD database amounted to about 10 per cent of the UK's resident population, making it proportionally the world's largest (Amankwaa, 2018; Amelung et al., 2020).

Upon its implementation in 1995, the UK's NDNAD was initially intended only to collect the DNA profiles from offenders convicted of serious violent crimes such as murder, rape, or aggravated assault. However, successive changes in legislation led to the collection of DNA (and fingerprints) from any person suspected of having committed an offence, also abolishing the previous requirement to destroy fingerprints, samples, and profiles upon acquittal of a suspect. Ultimately, these changes led to the considerable expansion of NDNAD. Similarly, the growth of federal and national DNA databases in the USA (which holds the world's second largest DNA database in absolute numbers, following China), was also a gradual process. Initially, state DNA databases in the USA almost exclusively collected DNA profiles of adult sexual offenders, although they soon expanded to include not only the DNA profiles of all convicted felons, but also of juvenile and misdemeanor offenders and even mere arrestees (Aronson, 2010; Rothstein \& Talbott, 2006).

However, as described by Andra le Roux-Kemp (2018), the legal trajectories of DNA databases in the UK and USA have since followed in opposite directions. The considerable expansion of the UK's NDNAD came under scrutiny in 2008 when, in S \& Marper v. United Kingdom, ${ }^{1}$ the European Court of Human Rights (ECHR) expressed privacy concerns regarding the storage of certain DNA profile categories. This resulted in legislation changes ordering the destruction of biological samples and elimination of DNA profiles of acquitted suspects or persons who have not been formally accused of any crime (Amankwaa \& McCartney, 2019). In contrast, in Maryland v. King, ${ }^{2}$ the US Supreme Court emphasized the government's legitimate interest and extraordinary utility of DNA profiles and comparative searches on DNA databases like CODIS. In the words of Le Roux-Kemp: 
...judgments of these two cases reflect the competing interests in the debate on the expansion of existing DNA databases. On the one hand, proponents of expansion emphasize the utility of DNA profiling and the potential of increased efficacy that an expanded DNA database holds, whereas the opponents show concern for individuals' civil liberties and particularly their privacy interests with regard to their genetic material and information. Moreover, an important aspect that was largely ignored in the Maryland judgment is that in most states in the USA, the burden to destroy a DNA sample and expunge a DNA profile from a database is placed on the arrestee, and the majority of these states do not require that arrestees be informed of state expungement policies.

(Le Roux-Kemp, 2018, pp. 235-236)

In addition to the developments described above regarding criminal DNA databases in the UK and USA, there are also other circumstances where information in non-criminal genetic databases might be used in a criminal investigation and accessed by the police (de Groot et al., 2020). In the UK, for example, it is possible to issue a court order allowing police access to stored DNA samples and/or genetic information in any database. In the USA there have also been a number contentious cases where police have sought and gained access to genetic information, including an instance where an individual was wrongly considered a potential suspect based on a familial search conducted in a recreational database (Forensic Genetics Policy Initiative, 2017). That is, databases voluntarily used by citizens to upload genetic data in order to know more about their health, ancestry and/or search for relatives. If storage of genetic information for non-police purposes were to become widespread and police access to such information were to be broadly facilitated, including familial searches, this would mean that any individual and their relatives could, in effect, be tracked using their DNA, undermining all existing safeguards for forensic DNA databases currently recognized internationally and urgently needed (Granja, 2020; Kennett, 2019; Murphy, 2018; Samuel \& Kennett, 2020).

In sum, notwithstanding our tendency to associate arbitrary abuses of state surveillance and police action to dictatorial regimes, several features and characteristics of genetic surveillance used in crime governance can be found across different political, cultural, and historical settings in regions all over the world. The expansion of genetic surveillance is thus a global reality (Hindmarsh \& Prainsack, 2010).

In this chapter we will address genetic surveillance by describing the forensic genetic technologies being used in Europe as an aid to criminal investigation, the trends in legislation and its frequently controversial and turbulent historical and social evolution. To do so, we have opted for the following structure: the first part provides an account of the different forensic genetic technologies and their historical benchmarks since the mid-1980s until the present. We entwine the historical outline with a discussion of the main 
controversies aroused by the different technologies, on the techno-scientific field, in the juridical-legal dimension, as well as on the ethical, social, and political levels.

In the second part, we present the existing regulations, legislative frameworks, and governance principles in European countries regarding the collection, use, and storage of genetic data. The different perspectives and perceptions surrounding forensic genetic technologies are not merely a matter or rhetorical discourse. The views they reflect - both in the form of visions and expectations - take on substance; they become materially embedded in structures, machines, routines, systems, objects, matters, bodies, and actions related to science and technology development (Latour, 1987, 2005). Although we do not share notions that presuppose a direct and unequivocal relationship between "ideas" and "matter" (Latour, 2000), the sociological understanding of the material medium in which forensic genetic technologies operate is paramount.

In the third part, we focus on the complex, messy and unstable nature of genetic surveillance for the governance of crime. Understanding the multiplicity and heterogeneity of genetic surveillance helps to avoid unwarranted ethnocentric generalizations that result from an overwhelming focus of research on the Anglophone world (Boersma et al., 2014).

\section{Between utopian and dystopian views: the trajectory of forensics genetics}

One of the reasons that explains the importance given to genetic information in criminal investigations, is the scientific statute of molecular genetics (Lynch et al., 2008). From the standpoint of several professional groups - ranging from forensic scientists to criminal investigators, judges and prosecutors, attorneys and the general public - DNA technologies and forensic genetic databases allegedly generate information that is "more scientific" and "more capable" to identify offenders through a swifter and more credible method (Cole, 2001; Lynch et al., 2008; Machado \& Prainsack, 2012). Thus, many commentators have emphasized the benefits of using genetic technologies such as DNA profiling in policing and as forensic evidence in courts, to improve the efficiency of the criminal justice system.

In western liberal democracies, most prominently in North America and Europe, innovations and developments in forensic genetics have been regularly accompanied by public controversies instigated by civic organizations (Amelung \& Machado, 2019; Machado \& Silva, 2019) and occasionally triggered by the media (Amelung \& Machado, 2019; Machado \& Santos, 2009, 2011; Martins, 2021). Concerns relating to excessive state control over citizens' sensitive data, risks to genetic privacy, as well threats to other civic rights such as presumption of innocence, autonomy, and liberty, have been at the heart of the public debate promoted by civic organizations (Amankwaa, 2018). Other issues of contention relate to the absent or fragile control over the state's handling of genetic and other sensitive data from citizens, as well as 
to the scrutiny regarding which agencies have access to such data and their different purposes (Amankwaa, 2019b; Machado \& Silva, 2014, 2016). Social scientists have also raised concerns concerning the stigmatization and criminalization of specific ethnic-racial populations and vulnerable groups (Duster, 2003; M'charek, Schramm \& Skinner, 2014; Machado, Granja \& Amelung, 2020; Skinner, 2018b; Toom et al., 2016).

The different viewpoints on the legitimacy and potential usefulness (or lack thereof) of forensic genetics in the governance of crime, or conversely on the fears of its risks and dangers to civil liberties and human rights, tend to be socially constructed within the parameters of what academics in the field of surveillance studies have described the spectrum between care and control (Lyon, 2001; Machado \& Silva, 2016, 2019; Wilson-Kovacs, 2014) or utopian and dystopian views. In this framework of co-existence and ambivalence, forensic genetics innovations are construed to serve particular politics of belonging or of exclusion, by appointing specific publics as beneficiaries of the technologies in the name of law and security, and other publics as potentially harmed by targeted re-inscription of suspicion (Amelung et al., 2020; Amelung \& Machado, 2019; Machado et al., 2020).

The activities of forensic genetics engage a diversified set of techniques, objects, social actors, and infrastructures: while the great revolution of the mid-1980s was Alec Jeffreys' "discovery" of "DNA fingerprints" (Williams \& Wienroth, 2014a), more than three decades later, the frontline of the debate in forensic genetics has shifted to controversial technologies aiming to predict physical appearance of unknown suspects, the use of recreational DNA databases for criminal investigation purposes, and the emergence of techniques able to generate genome wide data (Machado \& Granja, 2020; Wienroth, Morling \& Williams, 2014; Williams $\&$ Wienroth, 2014a). In order to outline the trajectory of forensic genetics, the following table (see Table 2.1) lays out the main landmarks in the historical evolution of forensic genetic technologies, side by side with the major controversies and social issues they generated. The structure of summaries presented in Table 2.1 (see below) was inspired on the "four waves of forensic genetics" proposed by Matthias Wienroth, Niels Morling, Robin and Williams (2014), adjusted and completed by a broad number of works on historical trajectories, techno-scientific, ethical, and societal controversies, as well as the main social and legal-regulatory changes.

Following the "discovery" of DNA fingerprints by Jeffreys, the first wave of forensic genetics was focused on establishing the credibility of DNA profiling and regulating its uses in criminal trials (Aronson, 2007; Derksen, 2003, 2010; Jasanoff, 2006; Lynch et al., 2008). The second wave referred to the establishment, expansion, and use of national criminal DNA databases across the world (Hindmarsh \& Prainsack, 2010) and the concomitant international exchange of DNA data (Machado et al., 2020; Machado \& Granja, 2018, 2019b; McCartney, 2014; Prainsack \& Toom, 2010, 2013). The third wave had to do with the development and increasing implementation of technologies that go beyond identification, such as familial searching in criminal DNA 


\section{Genetic Surveillance and Crime Control}

Table 2.1 Waves of technological innovations in forensic genetics

\begin{tabular}{|c|c|c|c|c|}
\hline Waves & $\begin{array}{l}\text { Genetic } \\
\text { technology }\end{array}$ & Applications & Controversies & Changes \\
\hline \multirow[t]{2}{*}{$\begin{array}{l}\text { First wave } \\
\text { (mid- } \\
\text { 1980s) }\end{array}$} & $\begin{array}{l}\text { "Discovery" of } \\
\text { DNA finger- } \\
\text { prints by Alec } \\
\text { Jeffreys (UK, } \\
1984 \text { ) }\end{array}$ & $\begin{array}{l}\text { In } 1988 \text { the Eng- } \\
\text { lishman Colin } \\
\text { Pitchfork was the } \\
\text { first person con- } \\
\text { victed through the } \\
\text { use of DNA } \\
\text { evidence }\end{array}$ & $\begin{array}{l}\text { "DNA Wars" in the USA } \\
\text { and the UK. Disputes } \\
\text { over the construction and } \\
\text { matching of DNA pro- } \\
\text { files, the estimates of } \\
\text { random match prob- } \\
\text { ability, the interpretation } \\
\text { of mixed and incomplete } \\
\text { profiles }\end{array}$ & $\begin{array}{l}\text { Biological } \\
\text { knowledge and } \\
\text { techniques had } \\
\text { to adapt to } \\
\text { requirements } \\
\text { and constraints } \\
\text { of the criminal } \\
\text { justice system } \\
\text { and the legal } \\
\text { system had to } \\
\text { react and } \\
\text { change to } \\
\text { accommodate } \\
\text { to those } \\
\text { developments }\end{array}$ \\
\hline & $\begin{array}{l}\text { Early stages of } \\
\text { research on the } \\
\text { potential } \\
\text { power of } \\
\text { human genet- } \\
\text { ics to indivi- } \\
\text { dualize people }\end{array}$ & $\begin{array}{l}\text { Experimental } \\
\text { work of using } \\
\text { DNA profiling in } \\
\text { criminal cases }\end{array}$ & $\begin{array}{l}\text { Worries about "CSI } \\
\text { effect" (popular culture } \\
\text { presenting DNA as } \\
\text { infallible evidence) }\end{array}$ & $\begin{array}{l}\text { Redefinition of } \\
\text { the rights and } \\
\text { status of the } \\
\text { suspect body; } \\
\text { redefinition of } \\
\text { criminal } \\
\text { evidence }\end{array}$ \\
\hline \multirow[t]{2}{*}{$\begin{array}{l}\text { Second } \\
\text { wave (mid- } \\
\text { 1990s) }\end{array}$} & $\begin{array}{l}\text { Establishment, } \\
\text { expansion, and } \\
\text { use of criminal } \\
\text { DNA data- } \\
\text { bases (UK, } \\
\text { 1995) }\end{array}$ & $\begin{array}{l}\text { DNA profiles } \\
\text { resulting from } \\
\text { crime scene traces } \\
\text { can be compared } \\
\text { with those inclu- } \\
\text { ded in the criminal } \\
\text { DNA database. In } \\
\text { the event of a } \\
\text { positive match, a } \\
\text { criminal suspect } \\
\text { might be found }\end{array}$ & $\begin{array}{l}\text { Ethical and civic concerns } \\
\text { regarding which cate- } \\
\text { gories of persons should } \\
\text { have their profiles taken, } \\
\text { speculatively searched, } \\
\text { and for how long. Poten- } \\
\text { tial of stigmatization of } \\
\text { particular groups (ethnic } \\
\text { and racial minorities and } \\
\text { specific nationalities) }\end{array}$ & $\begin{array}{l}\text { Legislative } \\
\text { changes to } \\
\text { accommodate } \\
\text { the creation of } \\
\text { national-based } \\
\text { computerized } \\
\text { databases con- } \\
\text { taining a large } \\
\text { number of } \\
\text { profiles }\end{array}$ \\
\hline & $\begin{array}{l}\text { Transnational } \\
\text { exchange of } \\
\text { DNA data } \\
\text { (across jur- } \\
\text { isdictions in } \\
\text { the EU, 2008) }\end{array}$ & $\begin{array}{l}\text { Reciprocal auto- } \\
\text { mated exchanges } \\
\text { of DNA profiles } \\
\text { between jurisdic- } \\
\text { tions for } \\
\text { comparison }\end{array}$ & $\begin{array}{l}\text { Transparency and privacy } \\
\text { concerns related to trans- } \\
\text { national exchange of } \\
\text { DNA data; risk of false } \\
\text { positives due to huge } \\
\text { amounts of DNA profiles } \\
\text { and different methods of } \\
\text { DNA profiling; lack of } \\
\text { harmonization and stan- } \\
\text { dardization; and lack of } \\
\text { transnational ethical } \\
\text { oversight }\end{array}$ & $\begin{array}{l}\text { EU law to } \\
\text { foster DNA } \\
\text { data exchange } \\
\text { among different } \\
\text { jurisdictions; } \\
\text { data protection } \\
\text { regulations }\end{array}$ \\
\hline
\end{tabular}


Table 2.1 Cont.

\begin{tabular}{|c|c|c|c|c|}
\hline Waves & $\begin{array}{l}\text { Genetic } \\
\text { technology }\end{array}$ & Applications & Controversies & Changes \\
\hline \multirow[t]{2}{*}{$\begin{array}{l}\text { Third } \\
\text { wave } \\
(2000 s)\end{array}$} & $\begin{array}{l}\text { Familial } \\
\text { searching in } \\
\text { criminal DNA } \\
\text { databases (the } \\
\text { UK pioneered } \\
\text { the regulation, } \\
2002 \text { ) }\end{array}$ & $\begin{array}{l}\text { Speculative search } \\
\text { in DNA databases } \\
\text { to search for crim- } \\
\text { inal suspects } \\
\text { through genetic } \\
\text { relatedness (e.g. } \\
\text { partial matches } \\
\text { with potential bio- } \\
\text { logical relatives) }\end{array}$ & $\begin{array}{l}\text { Economic, temporal and } \\
\text { human resources needed } \\
\text { to search, review, and } \\
\text { refine the selection and } \\
\text { follow up the pool of the } \\
\text { hundreds of potential } \\
\text { suspects. Controversies } \\
\text { related to genetic privacy, } \\
\text { information disclosure } \\
\text { and reproduction of } \\
\text { social inequalities }\end{array}$ & $\begin{array}{l}\text { Legislative } \\
\text { changes to } \\
\text { accommodate } \\
\text { the possibility } \\
\text { of conducting } \\
\text { familial search- } \\
\text { ing and forensic } \\
\text { DNA } \\
\text { phenotyping }\end{array}$ \\
\hline & $\begin{array}{l}\text { Forensic DNA } \\
\text { phenotyping } \\
\text { (the Nether- } \\
\text { lands pio- } \\
\text { neered the } \\
\text { regulation, } \\
\text { 2003) }\end{array}$ & $\begin{array}{l}\text { Infer human } \\
\text { externally visible } \\
\text { physical features - } \\
\text { eye, hair and skin } \\
\text { color - and con- } \\
\text { tinental-based } \\
\text { biogeographical } \\
\text { ancestry of crim- } \\
\text { inal suspects on } \\
\text { the basis of the } \\
\text { analysis of biolo- } \\
\text { gical materials } \\
\text { collected at crime } \\
\text { scene }\end{array}$ & $\begin{array}{l}\text { Concerns relate to col- } \\
\text { lectivization of suspicion, } \\
\text { and the renewing of } \\
\text { existing forms of stigma- } \\
\text { tization that further } \\
\text { exacerbate the crim- } \\
\text { inalization of certain } \\
\text { groups. Controversies } \\
\text { related to reliability, } \\
\text { utility, and legitimacy }\end{array}$ & $\begin{array}{l}\text { Increasing } \\
\text { relevance of } \\
\text { companies } \\
\text { marketing for- } \\
\text { ensic DNA } \\
\text { phenotyping }\end{array}$ \\
\hline \multirow[t]{2}{*}{$\begin{array}{l}\text { Fourth } \\
\text { wave (cur- } \\
\text { rent } \\
\text { scenario) }\end{array}$} & $\begin{array}{l}\text { Next } \\
\text { generation } \\
\text { sequencing }\end{array}$ & $\begin{array}{l}\text { Sequence whole } \\
\text { genome and/or } \\
\text { targeted approach } \\
\text { with DNA and } \\
\text { RNA-sequencing }\end{array}$ & $\begin{array}{l}\text { Statistical, computational, } \\
\text { ethical, legal, economic } \\
\text { and technical validation } \\
\text { issues }\end{array}$ & $\begin{array}{l}\text { Huge expansion } \\
\text { in the level of } \\
\text { depth and } \\
\text { breadth of } \\
\text { genetic informa- } \\
\text { tion cannot yet } \\
\text { be accom- } \\
\text { modate in pre- } \\
\text { sent legislation } \\
\text { of most jurisdic- } \\
\text { tions; urgent the } \\
\text { definition of } \\
\text { clear rules and } \\
\text { guidance. }\end{array}$ \\
\hline & $\begin{array}{l}\text { Familial } \\
\text { searches in } \\
\text { recreational } \\
\text { DNA data- } \\
\text { bases (the } \\
\text { USA reported } \\
\text { the first case, } \\
\text { 2018) }\end{array}$ & $\begin{array}{l}\text { Search for relatives } \\
\text { of potential sus- } \\
\text { pects in recrea- } \\
\text { tional DNA } \\
\text { databases }\end{array}$ & $\begin{array}{l}\text { Serious risks for public } \\
\text { trust in genetics }\end{array}$ & $\begin{array}{l}\text { Horizons of } \\
\text { using biobanks } \\
\text { from different } \\
\text { fields (research, } \\
\text { clinical, recrea- } \\
\text { tional) for crim- } \\
\text { inal investigation } \\
\text { leads to emer- } \\
\text { gence of new } \\
\text { ethical and social } \\
\text { hazards }\end{array}$ \\
\hline
\end{tabular}


databases and forensic DNA phenotyping (Granja, Machado, \& Queirós, 2020; Granja \& Machado, 2019, 2020; Haimes, 2006; Murphy, 2010; Samuel \& Prainsack, 2018; Wienroth, 2018, 2020).

Briefly, familial searching refers to speculative searches in criminal DNA databases for criminal suspects through genetic relatedness (e.g. partial matches with potential biological relatives) (Bieber, Brenner, \& Lazer, 2006; Chamberlain, 2012; Curran \& Buckleton, 2008; Flaus, 2013; García, Crespillo, \& Yurrebaso, 2017; Kim et al., 2011; Suter, 2010; Thomas, 2006). Forensic DNA phenotyping can be described as a set of techniques used to infer externally visible physical features - eye, hair, and skin color - and continental-based biogeographical ancestry of criminal suspects based on the analysis of biological materials collected at crime scenes (Daniel et al., 2015; Kayser, 2015; Kayser \& de Knijff, 2011; Kayser \& Schneider, 2009).

Anticipating the possibility of a fourth wave on the horizon, Wienroth, Morling, and Williams (2014) referred to the blurring of boundaries between medical and forensic genetics. The use of next-generation sequencing (NGS) (or massive parallel sequencing, MPS) is particularly relevant in this context, as it allows sequencing a whole genome or taking a targeted approach with DNA and RNA-sequencing (the latter improves the ability to look at alternative gene transcripts, mutations and changes in genes expression over time) (Amorim \& Pinto, 2018; Graffelman, Jain, \& Weir, 2017). More significantly, NGS generates a substantial quantity of sensible information that, while not essential for purposes identification, is relevant to infer traits of medical importance and to obtain markers that can reveal physical traits and biogeographic ancestry or reveal markers situated at coding regions.

Based on Matthias Wienroth, Niels Morling, and Robin Williams' conceptual framework, Granja (2020) argues that we are currently witnessing a consolidation of the fourth wave in largely unforeseen and unexpected ways. Coupled with the development and increasing use of NGS, we are also seeing the advent and expansion of long-range familial searches in recreational DNA databases. That is, the search of potential suspects' relatives in databases where citizens voluntarily upload genetic data to know more about their health, ancestry and/or to search for relatives (Kennett, 2019; Murphy, 2018; Samuel \& Kennett, 2020). In this book, besides addressing the technologies from previous waves, we also provide a critical enquiry into the ongoing fourth wave by exploring NGS (see Chapter 6).

The next section presents an overview of genetic surveillance in the governance of crime in Europe, focusing on legislation trends (more expansive or more restrictive) while outlining the uses made of the different forensic genetic technologies.

\section{The landscape of genetic surveillance in the governance of crime in Europe}

As described earlier, the establishment of criminal DNA databases began in the mid-1990s. The first forensic genetic database was set up in England and Wales in 1995, and countries such as the Netherlands (1997), Austria (1997), 
and Germany (1998) followed suit. It is estimated that there are now 69 countries around the world operating this type of database and that at least 34 countries are starting the process of implementing their own database (Butler \& Willis, 2020; Interpol, 2016; Prainsack \& Aronson, 2015). Such databases exist in different regions of the world, with a clear expansion in Europe and North America: however, recent developments point to growing expansion in Asia, particularly in China, and in South Africa (Forensic Genetics Policy Initiative, 2017).

The size of forensic genetic databases and their type of organization and regulation is extremely varied. Legislation can determine the possible purposes or uses of DNA databases, distinguishing between criminal identification, civil identification, and scientific research purposes. It can also define the scope and means of access to the information stored in a database: either extending access to several official bodies (judicial authorities and police forces) or restricting access to specific agents within the justice system. In addition, legislation also establishes which information can be communicated, whether only information about matches between genetic profiles or if other information can also be communicated (e.g. personal data of the person identified by means of the genetic profile).

Other issues that are usually contemplated in national legislations refer to the criteria for inclusion and elimination of genetic profiles and biological samples. The legislative frameworks across different countries present assorted options to determine the scope and extent of access to a DNA database, based on criteria such as crime typology, maximum term of sentence, age, likelihood of recidivism, etc. As a result, the law is expected to answer the following questions: who can be subject and under what circumstances shall profiles be inserted into the DNA database? What is the fate of biological samples collected from suspects or convicts? What are the expiration dates for storage of DNA profiles and samples?

In general terms, the criteria that govern the inclusion and removal of profiles and samples constitute the variable with the most significant impact on the size of databases of genetic profiles. According to Filipe Santos and colleagues, who carried out a study on legislative trends in DNA databases in Europe, a distinction can be made between countries with expansive and restrictive legislations (Santos, Machado, \& Silva, 2013). Following this typology the latter group includes the following countries: Germany, Belgium, Spain, France, the Netherlands, Hungary, Ireland, Italy, Luxembourg, Portugal, and Sweden. The countries with expansive legislation are Austria, Denmark, Scotland, Slovakia, Estonia, Finland, Latvia, Lithuania, and the United Kingdom.

In the authors' perspective, a country can be classified as following an expansionist tendency with respect to the development of such databases whenever its specific legal framework is unrestrictive regarding the insertion of profiles into the DNA database for forensic purposes (e.g., allows the inclusion of the DNA profile of any individual suspected of any punishable offense, whether a suspect or convicted person). Conversely, countries are considered to follow a restrictive tendency if their current legislation contemplates restrictions and limits to the uses of DNA databases, such as limits on the types of sentences or crimes eligible for inclusion of profiles in databases. 


\section{Genetic Surveillance and Crime Control}

Note that the apparent dichotomy between expansionist and restrictive tendencies refers to the potential specific effects of legislative provisions. These effects are reflected, for example, in the proportion of the national population present in each country's database. Table 2.2 shows the diversity of size from a sample of criminal DNA databases in Europe. It should be pointed out that France, for example, despite displaying a "restrictive" legislation (according to the previously mentioned study by Santos et al., 2013), has witnessed a remarkable expansion over recent years, currently possessing the third largest forensic DNA database in Europe. The database of genetic profiles in the United Kingdom remains the largest of all, notwithstanding recent legislative changes introduced in the wake of the ruling by the ECHR following S. \& Marper v. UK (McCartney, Williams \& Wilson, 2010).

Furthermore, the distinction between restrictive and expansive trends proposed by Santos and colleagues (2013) should be updated to also include legislation (or lack thereof) on the uses of the different forensic genetic technologies such as familial searching and forensic DNA phenotyping. For example, a country such as the Netherlands, previously classified as "restrictive" (2013), due to the inclusion of minor restrictions on the legal power to obtain DNA samples (Reed \& Syndercombe-Court, 2016), possesses a jurisdiction which actually allows a very expansive use of several controversial genetic technologies. In fact, the Netherlands has a track record of "innovation" regarding the regulation and practical application of genetic technologies for forensic purposes. In 1994 it was the first country to introduce specific legislation on the use of forensic DNA to compare DNA profiles from a suspect and from a crime scene (M'charek, Toom, \& Jong 2020; Toom, 2012). In 2003 the Netherlands was also a pioneer in regulating the use, in criminal investigations, of externally visible characteristics determined genetically (Hopman, 2020; Hopman \& M'charek, 2020; M'charek, 2008). Since then, controversial uses of DNA data techniques, such as forensic DNA phenotyping, familial searching, and

Table 2.2 Size of several forensic genetic databases in Europe

\begin{tabular}{llll}
\hline Country & Population & $\begin{array}{l}\text { Total no. of individuals } \\
\text { inserted in the Database }\end{array}$ & $\begin{array}{l}\text { Proportion of population } \\
\text { in the database }\end{array}$ \\
\hline Germany & 82.000 .000 & 857.000 & $1,0 \%$ \\
Austria & 8.100 .000 & 203.054 & $2,5 \%$ \\
Denmark & 5.500 .000 & 116.433 & $2,1 \%$ \\
France & 66.030 .000 & 3.282 .418 & $5,0 \%$ \\
Netherlands & 17.000 .000 & 237.254 & $1,4 \%$ \\
Scotland & 5.500 .000 & 311.107 & $5,7 \%$ \\
Hungary & 9.982 .000 & 148.384 & $1,5 \%$ \\
England \& Wales & 53.700 .000 & 4.733 .755 & $8,8 \%$ \\
Sweden & 9.894 .888 & 153.008 & $1,5 \%$ \\
\hline
\end{tabular}

Source: ENFSI (2016). 
mass screenings have become increasingly relevant in criminal investigations in the country (Jong \& M'charek, 2017).

Despite legislative differences between European DNA databases, the dominant trend towards a generalized use and a more harmonized exchange of information has been increasingly encouraged (Machado et al., 2020; Machado \& Granja, 2018; McCartney, Wilson, \& Williams, 2011; Prainsack \& Toom, 2010, 2013). A clear example of this is the Prüm system - a panEuropean network of reciprocal automated searching and comparison of DNA profile information (as well as fingerprints and vehicle registration data) conceived to step up cross-border cooperation, particularly in the fight against terrorism and cross-border crime (EU Council, 2008a, 2008b). In addition to fostering a closer collaboration among police forces in EU countries, the Prüm system was also intended as an additional motor of the pan-European integration project by attempting to overcome cultural, political and socioeconomic disparities. This is achieved through a combination of measures that set technological standards among countries and an on-going promotion of discourse focusing on security and risk prevention (Prainsack \& Toom, 2013).

Nonetheless, the goal to bridge disparities among EU countries is coupled with two other phenomena. On the one hand, it must contend with the diversity of criteria for insertion and removal of DNA profiles and preservation of samples across Europe. Such a heterogeneous landscape makes it difficult to ensure compliance with the principles of equality, proportionality, and presumption of innocence in the context of the transfer of information on DNA profiles between EU Member States. Studies on this topic have been highlighting an apparent insufficiency in policies regarding both the standardization and monitoring of cooperation activities, as well as the collection, storage, processing, interpretation and legal application of DNA profile information (Amankwaa, 2019a; McCartney et al., 2011; Santos \& Machado, 2017; Toom, 2018).

On the other hand, the goal to overcome disparities among EU states is paired with the consolidation of a broader social sorting system that highlights several geopolitical tensions. In other words, since national DNA databases tend to reflect policing practices that usually target minorities, such as foreigners and/or ethnic minorities (Chow-White \& Duster, 2011; Duster, 2006; Skinner, 2013, 2018a), by enabling the transnational exchange of data, the Prüm system has the power to reassert and extend the discriminatory power of DNA databases. The transnational exchange of DNA data in the EU thereby enables the (re)making of the connections between criminality and suspicious movements of data and of particular populations leaving specific national territories (Machado et al., 2020).

Regardless of its particular challenges, the Prüm system is exemplary of Europe-building practices. In a recent previous work with our colleague Nina Amelung (Amelung et al., 2020) we describe the Prüm system as an illustrative case to reveal how specific concepts and visions of Europe - and, we might add, of nationhood - become enacted through the designs of transnational DNA database systems. We show that Member States appropriate the requirements to join the transnational DNA data exchange as responses 
to and articulations of their own visions of Europe and nationhood. In this sense, we talk about the "hidden integration" deriving from an analysis of new transnational polities as outcomes of large-scale techno-political attempts at European integration. We also argue that multiple visions of "Europe" have been enacted, so we also understand the Prüm system as a mean of "disintegration" of Europe (Amelung et al., 2020).

\section{Multiplicity of genetic surveillance in Europe}

From decades of social sciences research into surveillance emerges the notion that nation states have the tendency to grow towards surveillance societies (Lyon, 1994, 2014). Genetic surveillance is by no means an exception. However, characteristics of genetic surveillance vary from place to place. Consequently, we need empirically informed relational studies of the multiple, hybrid and conflicted nature of such instances.

Significant economic and political investment has been made in the creation of criminal DNA databases. This investment is driven by the promise that new techno-scientific initiatives would deliver a variety of benefits for society, including more effective law enforcement and greater security (Tutton \& Levitt, 2010; Williams \& Johnson, 2008). However, there is a variety of empirical contours in how genetic surveillance has been implemented along the last three decades across countries in Europe. As described in the previous section of this chapter, although genetic data categories are technically and scientifically standardized, the national DNA databases have very different compositions - some are expansive and some more restrictive - and therefore incorporate very differently affected social groups. Therefore, it is important to view genetic surveillance as a process and not as an outcome that demands awareness of the social, cultural and historical roots and seek interconnections.

The main cause of this development of surveillance - and of genetic surveillance - is reputedly the worldwide stress by nation states on countering terrorism and cross-border crime (Ball \& Webster, 2003; Bigo \& Tsoukala, 2008; Hairston, 2002). For example, the Prüm system fosters the idea of Europe's technological and political integration in law enforcement through the transnational exchange of DNA profiles stored in the different national DNA databases of cooperating countries. Nonetheless, as previously mentioned, it is crucial not to underestimate the power of nationalism and the role of nation-states (Amelung et al., 2020; Misa \& Schot, 2005). Therefore, two questions are raised: does a monocausal relationship between the "global threats" of terrorism and cross-border crime and the expansion of genetic surveillance indeed exist? How can we accommodate and represent the heterogeneity of the European history of surveillance? Some North European countries, for instance, do not share the weighty surveillance past of their Eastern and Southern neighbours where authoritarian and totalitarian regimes have implemented repressive surveillance systems (Boersma et al., 2014). Nonetheless, criminal DNA databases were first implemented in North Europe (Hindmarsh \& Prainsack, 2010). 
Genetic surveillance refers us to the "sociotechnical imaginaries" described by Sheila Jasanoff and Sang-Hyun Kim as the ideas that become rooted in institutions, culture, and material artifacts and which unite members of a collective in a shared vision of a future achievable through advances in science and technology (Jasanoff \& Kim, 2015). From our point of view, the different countries are crossed by a pervading socio-technical imagery of "techno-optimism" regarding the value and potential of genetic surveillance in the governance of crime and its added value to enhance the capability and efficiency of the justice system. As Andrea Quinlan (2020) explains in her work on forensic rape kits in US labs, this kind of techno-optimism has a long history. Quinlan examines how decades of depositing hope on forensic science to solve the inefficiency and slowness of the criminal justice system gradually built an imaginary of optimism, extending to the media, political decisionmakers, sexual crime victim activists and other groups. Moreover, technooptimist visions are used to their own advantage by a booming forensic industry profiting from such optimism (Quinlan, 2020).

However, as Sheila Jasanoff also observes, socio-technical imageries become all the more pressing and visible when they coincide with other existing imageries (Quinlan, 2020, p. 6). This means that the techno-optimist element of genetic surveillance's socio-technical imaginary will tend to gain stability, robustness, and visibility whenever it "coincides" with other collective beliefs (imageries) already embedded in the scientific and technological and institutions, in political and government actors, in police forces and the justice system. For instance, both France and the UK currently possess the largest criminal DNA databases in Europe (Reed \& Syndercombe-Court, 2016). There are three main reasons that explain the long histories of surveillance practices in either country. First, one of the driving forces ensuring the penetration of central government into the lives of private citizens was the welfare state and its information-gathering needs, through which the "information state" uses technological developments to gather or store enormous amounts of data (Higgs, 2004). Second, since the late 1870s the "technological seduction" to use fingerprints was very strong in both countries, as a means to identify not just criminals, but also a wide range of population groups considered suspect for other reasons: the natives of colonies; recent immigrants; the poor, itinerant populations, "vagrants," prostitutes, etc. (Cole, 2001). Finally, although the process of systematic data gathering started long before the recent "Global War on Terror," the international discourse around this problem has produced deep longterm effects on policies and security agendas in both France and the UK.

Coupled with the coincidence of imageries, we argue that techno-optimism also requires different stakeholders to constantly negotiate between high and low expectations (Tutton, 2011), combining the optimist outlook of benefits with concerns regarding risks, fears, dangers and anxieties. On this point, Table 2.3 shows that the visions on DNA profiling among three groups of actors who are professionally engaged with DNA profiling (namely, scientists and laboratory technicians, criminal investigators, and attorneys, prosecutors and judges of endusers) depend on specific epistemic cultures whose focus highlight certain features 
Table 2.3 Visions about DNA profiling

\begin{tabular}{|c|c|c|c|}
\hline & Value & Perceived benefits & Perceived risks \\
\hline $\begin{array}{l}\text { Scientists and } \\
\text { laboratory } \\
\text { technicians }\end{array}$ & $\begin{array}{l}\text { Biological traces } \\
\text { analyzed in a } \\
\text { laboratory context } \\
\text { as something that } \\
\text { may subsequently } \\
\text { be useful for iden- } \\
\text { tifying a } \\
\text { perpetrator }\end{array}$ & $\begin{array}{l}\text { Most significant } \\
\text { mean of human } \\
\text { identification }\end{array}$ & $\begin{array}{l}\text { Contamination and false } \\
\text { identifications due to } \\
\text { insufficient quantity or } \\
\text { degradation of DNA } \\
\text { CSI effect (popular cul- } \\
\text { ture presenting DNA as } \\
\text { infallible evidence) }\end{array}$ \\
\hline $\begin{array}{l}\text { Criminal } \\
\text { investigators }\end{array}$ & $\begin{array}{l}\text { Biological traces } \\
\text { collected from a } \\
\text { crime scene as } \\
\text { something that } \\
\text { may be useful to } \\
\text { search for a crim- } \\
\text { inal suspect }\end{array}$ & $\begin{array}{l}\text { Credibility of sci- } \\
\text { ence to support } \\
\text { deciding a certain } \\
\text { course of criminal } \\
\text { investigation } \\
\text { through the } \\
\text { generation of } \\
\text { intelligence }\end{array}$ & $\begin{array}{l}\text { Potential errors in justice } \\
\text { due to excessive sig- } \\
\text { nificance given to DNA } \\
\text { evidence in detriment of } \\
\text { others leads and evidence }\end{array}$ \\
\hline $\begin{array}{l}\text { Attorneys, } \\
\text { prosecutors, } \\
\text { judges }\end{array}$ & $\begin{array}{l}\text { Reliable evidence } \\
\text { that might prove a } \\
\text { defendant's } \\
\text { innocence or } \\
\text { culpability }\end{array}$ & $\begin{array}{l}\text { Credibility of } \\
\text { science to support } \\
\text { court cases }\end{array}$ & $\begin{array}{l}\text { Questions about the qual- } \\
\text { ity of laboratory processes } \\
\text { and other issues relating } \\
\text { to sample collection, } \\
\text { preservation, and } \\
\text { contamination }\end{array}$ \\
\hline
\end{tabular}

Source: Authors.

over others (see also Machado \& Granja, 2019a; Williams \& Johnson, 2004). Thus, we find common aspects and continuities to genetic surveillance in the governance of crime across different countries. This coexistence can be witnessed, for instance, in the concurrent presence of utopian and dystopian values: law and order vis a vis privacy and freedom; justice system efficiency and DNA as "truth machine" versus the criminalization of specific social groups; belief in the infallibility of DNA evidence as opposed to justice's vulnerability to error.

At the same time, the multiplicity and heterogeneity of genetic surveillance in the governance of crime in Europe also opens the door to explore the complexity of crucial cultural and historical problems. For instance, we cannot ignore a specific reference to post-authoritarian societies in Europe. In some contexts, surveillance has continued to permeate the relationship between the state and its citizens well beyond the end of past authoritarian regimes. However, not only it would be misleading to analyze these post-authoritarian societies along the same lines as "surveillance societies" that have not experienced a transition to democracy, but even among the former, not all transitions represent the same for each country or impact similarly upon their societies.

For example, we can briefly evoke three very different national cases of genetic surveillance in the governance of crime, such as Germany, Portugal, and Poland (Amelung et al., 2020; Amelung, Queirós \& Machado, 2021; 
Granja \& Machado, 2019). Despite socio-cultural and historical differences, as well as huge disparities in economic development and the presence of science and technology innovation, they share a common feature: they all fall into the category of post-authoritarian surveillance societies.

Germany has a historical legacy that combines both the violent state surveillance imposed during the Nazi-regime and the repressive surveillance imposed in the former German Democratic Republic (East Germany) by the secret police agencies of the Ministry for State Security, commonly known as the Stasi. East Germany was a communist state, characterized by a totalitarian or severely authoritarian regime inspired on the Soviet model, whose existence as a country lasted between 1949 and 1990, when it was dissolved and reunited with West Germany, on October 3, 1990. Therefore, referring to "Germany" as a unique, homogenous society becomes particularly problematic and ambiguous. More than 70 years after the Second World War and 30 years after reunification, collective memories of the Nazi regime as well as memories of the East German police state continue to affect public views of state surveillance (Lichter, Löffler, \& Siegloch, 2020). In this regard, Germany's historical and cultural particularities make it stand out in terms of its relation to genetics. Public perceptions in Germany on this issue are still influenced by memories of Germany's Nazi past and the role science played in racializing genetics and supporting the eugenics movement (Kattmann, 2017). Germany's past has contributed to a strong awareness regarding genetics and a general scepticism about allowing state and law enforcement agencies having to have access to sensitive genetic information of its citizens (Sperling, 2008). Such public scepticism was also dominant when the German DNA database was established in 1998 (Lee, 2016). The particular sense of nationhood in Germany is therefore entangled with cultural meanings attached to forensic DNA technologies that reveal historical traumas and their potential to enforce socially constructed differences between population groups. Alongside the data protection commissioners and parliament, other stakeholders complement the cluster of public voices that (often critically) scrutinize the national DNA database, DNA technology development, and data exchange. Several social scientists as well as civil society actors within Germany also have cast a critical eye over the evolution of the DNA database (Williams \& Wienroth, 2014b).

Poland also experienced extreme surveillance, through highly secretive and extensive information systems designed to control and subjugate entire populations. Between 1795 and 1918 its history was predominantly characterized by occupation and control by foreign powers, as it was divided between the Russian, Prussian, and Austrian Empires before securing independence in 1918. However, from the end of the Second World War until the fall of the communist regime in 1989 Poland once again fell under the control of a foreign power, this time the Soviet Union. The criminal justice system was instrumentalized to ensure conformity with the rules of the Communist Party, and its effects have lasted until today (Ryan, 2016, p. 310). Recently, Poland passed a couple of laws to reform its judicial and criminal justice 
system, including the police law of 2016, which expanded the powers Polish police by granting law enforcement agencies much broader surveillance capacity over the population (Karolewski \& Benedikter, 2017). As a consequence, there have been some tensions between Poland and the democratic standards of the EU regarding the rule of law and human rights.

The magnitude of migration flows from Poland (and some other East European countries) to other European countries, coupled with assumptions about the role of Polish criminal networks, have shaped the imagination of security professionals engaged in EU transnational police and judiciary cooperation. The discourse of professionals operating the Prüm system about the importance of joining collective efforts to control cross-border criminality in the EU are framed by said assumptions, helping to explain the interest of other Member States in data exchange with Poland (Machado et al., 2020). This is met by Poland's own interest to invest in DNA technologies, as they represent a path towards technological modernization and integration with Europe, catching up with international crime-control standards (Amelung et al., 2020).

Another feature that is specific of Poland concerns its investment in the potential of DNA technologies to overcome national traumas. In a country that has been historically affected by the disappearance of its people (Colls, 2016), DNA technologies can be applied to overcome painful and traumatizing periods in its history and to give visibility, dignity, and respect to victims of oppression and their relatives (Granja \& Machado, 2019).

Finally, Portugal's twentieth century history is heavily marked by a long period of political dictatorship (1926-74), characterized by political repression and censorship (Durão, 2008; Pimentel, 2007; Ribeiro, 1995), leaving an indelible mark on society which reflected particularly on Portugal's legal and criminal justice culture. For example, police forces were strongly linked in the collective imagination to the authoritarian nature of this dictatorial regime (Durão, 2008). Currently, the heritage of an authoritarian state is mostly reflected in citizens' passive compliance with the state's heavily bureaucratic mechanisms, namely its power to collect personal data, while at the same time contributing to undermine public confidence in the police and the justice system (Machado \& Frois, 2014).

After the democratic revolution of 1974, the Portuguese state began to focus on investing on modernization and progress, turning to European standards as its figure model (Frois \& Machado, 2016). Within this trajectory, DNA technologies have emerged as a symbol of the modernization and progress that the state has sought to introduce across its different areas of activity, including criminal investigation, as a way to emulate the models of other European countries (Machado $\&$ Frois, 2014). The political project of a technologically driven modernization of criminal investigation - including the establishment of a universal national DNA database (Machado \& Silva, 2010) - has nonetheless suffered the influence of this country's socio-economic and cultural particularities, marked by a fragile economy and a seemingly paradoxical contrast between consistently low criminality rates and the low levels of public confidence in the state, the police and the criminal justice system (Transparency International, 2019). 
In sum, this brief description has sought to show that even though not all post-authoritarian countries rely equally on sophisticated technologies for surveillance of populations, the multifaceted penetration of cultures of fear and suspicion are deeply ingrained and enduring. The study of genetic surveillance in the governance of crime across the group of countries contemplated in this study (Amelung et al., 2020) therefore offers the opportunity to analyze the multiple and heterogenous dynamics of fluxes between nontechnological to technology-based surveillance.

\section{Conclusion}

Within the scope of this book we survey the landscape of genetic surveillance in the governance of crime in Europe, while keeping in mind that technologies of genetic surveillance for the governance of crime, as they are envisioned and produced in the West and Global North, tend also to provide a model for the rest of the world. This phenomenon reflects the typical diffusion pattern of "high-tech" innovations, which raises ethical and political dilemmas. In the words of Sheila Jasanoff:

Novel technologies originate where wealth and knowledge are most concentrated and are then exported to other societies and cultures with considerably different histories of technology and governance. We know from decades of work on the co-production of natural knowledge and social order that technologies are never ethically or politically neutral: they carry within them, particular, culturally conditioned imaginaries of good and evil, what (and, in the case of DNA profiles who) should be encouraged and what (or who) should be suppressed.

(Jasanoff, 2010, p. xxiii)

The typical diffusion pattern of forensic genetic technologies in the governance of crime had a renewed academic impact in the field of social sciences, where until recently, the existing literature had mostly focused on the cases of the UK and the USA. From our perspective, this focus tended to ignore the variability of social, ethical, and political challenges of genetic surveillance in the governance of crime across different political social and cultural contexts. Our aim is to highlight the multiplicity and heterogeneity of genetic surveillance in the governance of crime across Europe, based on our analysis and reflection upon the different challenges posed by the implementation of forensic genetics in specific justice systems. We do so by situating the trajectory of forensic genetics and the panorama of genetic surveillance within specific contexts that are shaped by the (differentiated) weight of sociohistorical and techno-political backgrounds, the availability of technical database infrastructures and innovation development, the influence of distinctive forms of state accountability, and the contingent and circumstantial character of what is each society perceives as socially legitimate uses of genetic technologies. 
This approach allows us not only to identify differences and similarities, tensions and contradictions, within the European scenario, but also to anchor them on broader historical, social, and political issues. This method thereby shows how the material dimension of genetic surveillance - legislative frameworks and regulations; DNA technology and scientific knowledge; technical database infrastructure for storing and comparing genetic data; and organizational imperatives (Johnson, Williams \& Martin, 2003, p. 26) - are not fixed or given, neither are hopes and promises, or fears and anxieties aroused by them. They are both relational, and they have to be constructed and interpreted (Law, 2008; Lynch, 2016).

On the other hand, our intention is also to underline the urgency and timeliness of debating the broader repositioning of genetic surveillance in the governance of crime in the post-DNA era. More than ever it is crucial to provide an ambitious social theorization that might help us to frame and interpret, on the one hand, how genetics is transforming - in a process made up of transitions, frictions and tensions - the identities and bodies as they are entangled in networks of suspicion woven by techo-scientific devices; on the other hand, how affected publics confer meaning, negotiate and navigate the complex and challenging relations forged between science and society. In order to do so, however, it is essential to emphasize the complex, multilayered processes underlying the uses of genetic surveillance in the governance of crime, which in turn privilege, authorize, and legitimate the visions and expectations of certain actors, while others are marginalized or excluded.

\section{Notes}

$1 \mathrm{~S} \&$ Marper vs. UK refers to a complaint lodged with the European Court of Human Rights by two individuals (S, an 11-year-old child and Marper) against the United Kingdom. Both S. and Marper were detained in unrelated circumstances in 2001, and their fingerprints and DNA samples were collected. No accusations resulted from the arrests, leading them to petition the Chief Constable to eliminate the records. Their requests were denied. After appeals from the Chief Constable's decision to the courts and the House of Lords, it was determined that notwithstanding the absence of criminal charges against these individuals, and despite the possible breach of privacy, fingerprint retention and DNA profiling was considered to be beneficial to society (McCartney et al., 2010). The ECHR's decision ruled differently, and determined that the retention of fingerprints and DNA profiles of suspects who haven't been convicted constitutes a "disproportionate interference" with an individual's rights to privacy and "cannot be taken for granted in a democratic society” (S \& Marper vs. UK, 2008, p. par.125).

2 https://supreme.justia.com/cases/federal/us/569/435.

\section{References}

Amankwaa, A.O. (2018). Forensic DNA retention: public perspective studies in the United Kingdom and around the world. Science \& Justice, 58(6), 455-464. https:// doi.org/10.1016/j.scijus.2018.05.002. 
Amankwaa, A.O. (2019a). Trends in forensic DNA database: transnational exchange of DNA data. Forensic Sciences Research, 5(1), 8-14. https://doi.org/10.1080/ 20961790.2019 .1565651$.

Amankwaa, A.O. (2019b). Forensic DNA Databasing: Retention Regimes and Efficacy [Doctoral Dissertation, Northumbria University].

Amankwaa, A.O. \& McCartney, C. (2019). The effectiveness of the UK national DNA database. Forensic Science International: Synergy, 1, 45-55. https://doi.org/10. 1016/J.FSISYN.2019.03.004.

Amelung, N., Granja, R., \& Machado, H. (2020). Modes of Bio-Bordering: The Hidden (Dis) integration of Europe (1st ed.). London: Palgrave Macmillan. https:// doi.org/10.1007/978-981-15-8183-0.

Amelung, N. \& Machado, H. (2019). Affected for good or for evil: the formation of issue-publics that relate to the UK national DNA database. Public Understanding of Science, 28(5), 590-605. https://doi.org/10.1177/0963662519836346.

Amelung, N., Queirós, F., \& Machado, H. (2021). Desafios Éticos e Democráticos da Vigilância Genética na Alemanha e em Portugal. In H. Machado (Ed.), Crime e Tecnologia: Desafios Culturais e Políticos para a Europa (pp. 41-63). Porto: Afrontamento.

Amorim, A. \& Pinto, N. (2018). Big data in forensic genetics. Forensic Science International: Genetics, 37, 102-105. https://doi.org/10.1016/J.FSIGEN.2018.08.001.

Aronson, J. (2007). Genetic Witness: Science, Law, and Controversy in the Making of DNA Profiling. Piscataway, NJ: Rutgers University Press.

Aronson, J. (2010). On Trial! Governing Forensic DNA Technologies in the USA. In R. Hindmarsh \& B. Prainsack (Eds), Genetic Suspects. Global Governance of Forensic DNA Profiling and Databasing, 240-261. Cambridge: Cambridge University Press.

Ball, K. \& Webster, F. (Eds). (2003). The Intensification of Surveillance: Crime, Terrorism and Warfare in the Information Era. London: Pluto Press.

Bieber, F.R., Brenner, C.H., \& Lazer, D. (2006). Finding criminals through DNA of their relatives. Human Genetics, 312(5778), 1315-1316. https://doi.org/10.1126/sci ence. 1122655 .

Bigo, D. \& Tsoukala, A. (Eds). (2008). Terror, Insecurity and Liberty Illiberal Practices of Liberal Regimes After 9/11. London: Routledge.

Boersma, K., Brakel, R. Van, Fonio, C., \& Wagenaar, P. (Eds). (2014). Histories of State Surveillance in Europe and Beyond. London: Routledge.

Butler, J.M. \& Willis, S. (2020). Interpol review of forensic biology and forensic DNA typing 2016-2019. Forensic Science International: Synergy, 2, 352-367. https://doi. org/10.1016/j.fsisyn.2019.12.002.

Chamberlain, M. (2012). Familial DNA searching. A proponent's perspective. Criminal Justice, 27(1), 18-30. www.americanbar.org/content/dam/aba/publications/crim inal_justice_magazine/sp12_dna_search_proponents.authcheckdam.pdf.

Chow-White, P. \& Duster, T. (2011). Do health and forensic DNA databases increase racial disparities? PLoS Medicine, 8(10), e1001100. https://doi.org/10.1371/journal. pmed.1001100.

Cole, S. (2001). Suspect Identities: A History of Fingerprinting and Criminal Identification. Cambridge: Harvard University Press.

Colls, C.S. (2016). 'Earth Conceal Not My Blood': Forensic and Archaeological Approaches to Locating the Remains of Holocaust Victims. In J.-M. Dreyfus \& É. Anstett (Eds), Human Remains in Society: Curation and Exhibition in the Aftermath of Genocide and Mass-violence, 163-196. Manchester: Manchester University Press. 
Curran, J. \& Buckleton, J.S. (2008). Effectiveness of familial searches. Science \& Justice, 48(4), 164-167. https://doi.org/10.1016/j.scijus.2008.04.004.

Daniel, R., Santos, C., Phillips, C., Fondevila, M., Oorschot, R. Van, Carracedo, Á., Lareu, M.V., \& McNevin, D. (2015). A SNaPshot of next generation sequencing for forensic SNP analysis. Forensic Science International: Genetics, 14, 50-60. https:// doi.org/10.1016/j.fsigen.2014.08.013.

de Groot, N.F., van Beers, B.C., Decock, L., \& Meynen, G. (2020). Accessing medical biobanks to solve crimes: ethical considerations. Journal of Medical Ethics, 1-8. https://doi.org/10.1136/medethics-2020-106133.

Derksen, L. (2003). Agency and Structure in the History of DNA Profiling: The Stabilization and Standardization of a New Technology [Doctoral Dissertation, University of California, San Diego].

Derksen, L. (2010). Micro/macro translations: the production of new social structures in the case of DNA profiling. Sociological Inquiry, 80(2), 214-240. https://doi.org/ 10.1111/j.1475-682X.2010.00328.x.

Downey, J., Stephens, M., \& Flaherty, J. (2012). The 'sluice-gate' public sphere and the national DNA database in the UK. Media, Culture \& Society, 34(4), 439-456. https:// doi.org/10.1177/0163443711436357.

Durão, S. (2008). Patrulha e Proximidade: Uma Etnografia da Polícia em Lisboa. Coimbra: Almedina.

Duster, T. (2003). Backdoor to Eugenics. London: Routledge.

Duster, T. (2006). Explaining differential trust of DNA forensic technology: grounded assessment or inexplicable paranoia? The Journal of Law, Medicine \& Ethics, 34(2), 293-300. https://doi.org/10.1111/j.1748-720X.2006.00034.x.

ENFSI. (2016) ENFSI Survey on DNA Databases in Europe. http://enfsi.eu/wp-con tent/uploads/2017/01/ENFSI-Survey-on-DNA-Databases-in-Europe-June-2016.pdf.

EU Council. (2008a). Council Decision 2008/615/JHA of 23 June 2008 on the stepping up of cross-border cooperation, particularly in combating terrorism and crossborder crime. Official Journal of the European Union. Brussels.

EU Council. (2008b). Council Decision 2008/616/JHA of 23 June 2008 on the implementation of Decision 2008/615/JHA on the stepping up of cross-border cooperation, particularly in combating terrorism and cross-border crime. Official Journal of the European Union. Brussels.

Flaus, A. (2013). Familial Searches and the New Zealand DNA Profile Databank: The Thin Edge of the Genetic Wedge? [Dissertation of the degree of Bachelor of Laws, University of Otago]. www.otago.ac.nz/law/research/journals/otago065282.pdf.

Forensic Genetics Policy Initiative. (2017). Establishing best practice for forensic DNA databases. Windsor: Forensic Genetics Policy Initiative. www.genewatch.org/uploads/ f03c6d66a9b354535738483c1c3d49e4/BestPractice_Report_plus_cover_final.pdf.

Frois, C., \& Machado, H. (2016). Modernization and Development as a Motor of Polity and Policing. In B. Bradford, B. Jauregui, I. Loader, \& J. Steinberg (Eds), The SAGE Handbook of Global Policing, 391-405. Thousand Oaks: SAGE Publications.

García, Ó., Crespillo, M., \& Yurrebaso, I. (2017). Suspects identification through "familial searching" in DNA databases of criminal interest. Social, ethical and scientific implications. Spanish Journal of Legal Medicine, 43(1), 26-34. https://doi.org/ 10.1016/j.remle.2017.02.002.

Graffelman, J., Jain, D., \& Weir, B. (2017). A genome-wide study of Hardy-Weinberg equilibrium with next generation sequence data. Human Genetics, 136(6), 727-741. https://doi.org/10.1007/s00439-017-1786-7. 
Granja, R. (2020). Long-range familial searches in recreational DNA databases: expansion of affected populations, the participatory turn, and the co-production of biovalue. New Genetics and Society, 1-22. https://doi.org/10.1080/14636778.2020.1853515.

Granja, R. \& Machado, H. (2019). Ethical controversies of familial searching: the views of stakeholders in the United Kingdom and in Poland. Science, Technology, \& Human Values, 44(6), 1068-1092. https://doi.org/10.1177/0162243919828219.

Granja, R. \& Machado, H. (2020). Forensic DNA phenotyping and its politics of legitimation and contestation: views of forensic geneticists in Europe. Social Studies of Science, 1-19. https://doi.org/10.1177/0306312720945033.

Granja, R., Machado, H., \& Queirós, F. (2020). The (de)materialization of criminal bodies in forensic DNA phenotyping. Body \& Society, 1-25. https://doi.org/10.1177/ 1357034 X20919168.

Haimes, E. (2006). Social and ethical issues in the use of familial searching in forensic investigations: insights from family and kinship studies. The Journal of Law, Medicine \& Ethics, 34(2), 263-276. https://doi.org/10.1111/j.1748-720X.2006.00032.x.

Hairston, C.F. (2002, 30-31 January). Prisoners and families: parenting issues during incarceration [Conference presentation]. From Prison to Home: The Effects of Incarceration and Reentry on Children, Families and Communities Conference, U. S. Department of Health and Human Services.

Higgs, E. (2004). The Information State in England: The Central Collection of Information on Citizens Since 1500. London: Red Globe Press.

Hindmarsh, R. \& Prainsack, B. (Eds). (2010). Genetic Suspects: Global Governance of Forensic DNA Profiling and Databasing. Cambridge: Cambridge University Press.

Hopman, R. (2020). Opening up forensic DNA phenotyping: the logics of accuracy, commonality and valuing. New Genetics and Society, 39(4), 424-440. https://doi.org/ 10.1080/14636778.2020.1755638.

Hopman, R. \& M'charek, A. (2020). Facing the unknown suspect: forensic DNA phenotyping and the oscillation between the individual and the collective. BioSocieties, 15, 438-462. https://doi.org/10.1057/s41292-020-00190-9.

Hufnagel, S. (2017). Regulation of cross-border law enforcement: 'locks' and 'dams' to regional and international flows of policing. Global Crime, 18(3), 218-236. https:// doi.org/10.1080/17440572.2017.1345681.

Interpol. (2016). Global DNA profiling survey results 2016. Lyons. www.interpol.int/ content/download/4875/file/GlobalDNASurvey.pdf.

Jasanoff, S. (2006). Just evidence: the limits of science in the legal process. The Journal of Law, Medicine \& Ethics, 34(2), 328-341. https://doi.org/10.1111/j.1748-720X. 2006.00038.x.

Jasanoff, S. (2010). Foreword. In R. Hindmarsh \& B. Prainsack (Eds), Genetic Suspects: Global Governance of Forensic DNA Profiling and Databasing (pp.xix-xxiv). Cambridge: Cambridge University Press.

Jasanoff, S. \& Kim, S.-H. (Eds). (2015). Dreamscapes of Modernity: Sociotechnical Imaginaries and the Fabrication of Power. Chicago and London: University of California Press. https://doi.org/10.7208/chicago/9780226276663.001.0001.

Johnson, P. \& Williams, R. (2007). Internationalizing new technologies of crime control: forensic DNA databasing and datasharing in the European Union. Policing \& Society, 17(2), 103-118. https://doi.org/10.1080/10439460701302669.

Johnson, P., Williams, R., \& Martin, P. (2003). Genetics and forensics: making the national DNA database. Science Studies, 16(2), 22-37. www.pubmedcentral.nih. gov/articlerender.fcgi?artid=PMC1351151. 
Jong, L. \& M'charek, A. (2017). The high-profile case as 'fire object': following the Marianne Vaatstra murder case through the media. Crime, Media, Culture: An International Journal, 14(3), 347-363. https://doi.org/10.1177/1741659017718036.

Karolewski, I.P. \& Benedikter, R. (2017). Poland's conservative turn and the role of the European Union. European Political Science, 16(4), 515-534. https://doi.org/10. 1057/s41304-016-0002-x.

Kattmann, U. (2017). Reflections on "race" in science and society in Germany. Journal of Anthropological Sciences, 95, 311-318. https://doi.org/10.4436/JASS.95010.

Kayser, M. (2015). Forensic DNA phenotyping: predicting human appearance from crime scene material for investigative purposes. Forensic Science International: Genetics, 18, 33-48. https://doi.org/10.1016/j.fsigen.2015.02.003.

Kayser, M. \& de Knijff, P. (2011). Improving human forensics through advances in genetics, genomics and molecular biology. Nature Reviews Genetics, 12(3), 179-192. https://doi.org/10.1038/nrg2952.

Kayser, M. \& Schneider, P. (2009). DNA-based prediction of human externally visible characteristics in forensics: motivations, scientific challenges, and ethical considerations. Forensic Science International: Genetics, 3(3), 154-161. https://doi.org/10. 1016/j.fsigen.2009.01.012.

Kennett, D. (2019). Using genetic genealogy databases in missing persons cases and to develop suspect leads in violent crimes. Forensic Science International, 301, 107-117. https://doi.org/10.1016/j.forsciint.2019.05.016.

Kim, J., Mammo, D., Siegel, M.B., \& Katsanis, S.H. (2011). Policy implications for familial searching. Investigative Genetics, 2(22), 1-9. https://doi.org/10.1186/2041-2223-2-22.

Latour, B. (1987). Science in Action. How to Follow Scientists and Engineers Through Society. Cambridge: Harvard University Press.

Latour, B. (2000). When things strike back: a possible contribution of 'science studies' to the social sciences. The British Journal of Sociology, 51(1), 107-123. https://doi. org/10.1111/j.1468-4446.2000.00107.x.

Latour, B. (2005). Reassembling the Social. An Introduction to Actor-Network-Theory. Oxford: Oxford University Press.

Law, J. (2008). On sociology and STS. The Sociological Review, 56(4), 623-649. https:// doi.org/10.1111/j.1467-954X.2008.00808.x.

Le Roux-Kemp, A. (2018). Forensic DNA databases in Hong Kong and China: a BRICS comparative perspective. Indiana International and Comparative Law Review, 28(2), 221-272.

Lee, J. (2016). The presence and future of the use of DNA-information and the protection of genetic informational privacy: a comparative perspective. International Journal of Law, Crime and Justice, 44, 212-229. https://doi.org/10.1016/j.ijlcj.2015.10.001.

Leibold, J. \& Emile D. (2020, June 17). Genomic surveillance: inside China's DNA dragnet. The Strategist. www.aspistrategist.org.au/genomic-surveillance-inside-china s-dna-dragnet.

Lichter, A., Löffler, M., \& Siegloch, S. (2020). The long-term costs of government surveillance: insights from Stasi Spying in East Germany. Journal of the European Economic Association, 1-49. https://doi.org/10.1093/jeea/jvaa009.

Lynch, M. (2016). Social constructivism in science and technology studies. Human Studies, 39(1), 101-112. https://doi.org/10.1007/s10746-016-9385-5.

Lynch, M., Cole, S. A., McNallly, R., \& Jordan, K. (2008). Truth Machine: The Contentious History of DNA Fingerprinting. Chicago: University of Chicago Press. https://doi.org/10.1017/CBO9781107415324.004. 
Lyon, D. (1994). The Electronic Eye: The Rise of Surveillance Society. Cambridge: Polity Press.

Lyon, D. (2001). Facing the future: seeking ethics for everyday surveillance. Ethics and Information Technology, 3(3), 171-180. https://doi.org/10.1023/a:1012227629496.

Lyon, D. (2014). Surveillance, Snowden, and big data: capacities, consequences, critique. Big Data \& Society, 1(2), 1-13. https://doi.org/10.1177/2053951714541861.

M'charek, A. (2008). Silent witness, articulate collective: DNA evidence and the inference of visible traits. Bioethics, 22(9), 519-528. https://doi.org/10.1111/j. 1467-8519.2008.00699.x.

M'charek, A., Schramm, K., \& Skinner, D. (2014). Technologies of belonging: the absent presence of race in Europe. Science, Technology, \& Human Values, 39(4), 459-467. https://doi.org/10.1177/0162243914531149.

M'charek, A., Toom, V., \& Jong, L. (2020). The trouble with race in forensic identification. Science, Technology, \& Human Values, 45(5), 804-828. https://doi.org/10. $1177 / 0162243919899467$.

Machado, H. \& Frois, C. (2014). Aspiring to Modernization: Historical Evolution and Current Trends of State Surveillance in Portugal. In K. Boersma, R. van Brakel, C. Fonio, \& P. Wagenaar (Eds), Histories of State Surveillance in Europe and Beyond, 65-78. London: Routledge.

Machado, H. \& Granja, R. (2018). Ethics in transnational forensic DNA data exchange in the EU: constructing boundaries and managing controversies. Science as Culture, 27(2), 242-264. https://doi.org/10.1080/09505431.2018.1425385.

Machado, H. \& Granja, R. (2019a). Police epistemic culture and boundary work with judicial authorities and forensic scientists: the case of transnational DNA data exchange in the EU. New Genetics and Society, 38(3), 289-307. https://doi.org/10. 1080/14636778.2019.1609350.

Machado, H. \& Granja, R. (2019b). Risks and benefits of transnational exchange of forensic DNA data in the EU: the views of professionals operating the Prüm system. Journal of Forensic and Legal Medicine, 68, 1-7. https://doi.org/10.1016/J. JFLM.2019.101872.

Machado, H. \& Granja, R. (2020). Forensic Genetics in the Governance of Crime. Singapore: Springer Singapore. https://doi.org/10.1007/978-981-15-2429-5.

Machado, H., Granja, R., \& Amelung, N. (2020). Constructing suspicion through forensic DNA databases in the EU. The views of the Prüm professionals. The British Journal of Criminology, 60(1), 141-159. https://doi.org/10.1093/bjc/azz057.

Machado, H. \& Prainsack, B. (2012). Tracing Technologies: Prisoners' Views in the Era of CSI. Farnham: Ashgate.

Machado, H. \& Santos, F. (2009). The disappearance of Madeleine McCann: public drama and trial by media in the portuguese press. Crime, Media, Culture, 5(2), 146-167. https:// doi.org/10.1177/1741659009335691.

Machado, H. \& Santos, F. (2011). Popular press and forensic genetics in Portugal: expectations and disappointments regarding two cases of missing children. Public Understanding of Science, 20(3), 303-318. https://doi.org/10.1177/0963662509336710.

Machado, H. \& Silva, S. (2010). Portuguese Forensic DNA Database: Political Enthusiasm, Public Trust and Probable Issues in Future Practice. In R. Hindmarsh \& B. Prainsack (Eds), Genetic Suspects: Global Governance of DNA Profiling and Databasing, 218-239. Cambridge: Cambridge University Press.

Machado, H. \& Silva, S. (2014). "Would you accept having your DNA profile inserted in the National Forensic DNA database? Why?" Results of a questionnaire applied 
in Portugal. Forensic Science International: Genetics, 8(1), 132-136. https://doi.org/ 10.1016/j.fsigen.2013.08.014.

Machado, H. \& Silva, S. (2016). Voluntary participation in forensic DNA databases: altruism, resistance, and stigma. Science, Technology, \& Human Values, 41(2), 322343. https://doi.org/10.1177/0162243915604723.

Machado, H. \& Silva, S. (2019). What influences public views on forensic DNA testing in the criminal field? A scoping review of quantitative evidence. Human Genomics, 13(23), 1-13. https://doi.org/10.1186/s40246-019-0207-5.

Martins, M. (2021). News media representation on EU immigration before Brexit: the 'Euro-Ripper' case. Humanities and Social Sciences Communications, 8(1), 1-8. https:// doi.org/10.1057/s41599-020-00687-5.

McCartney, C. (2014). Trans-national Exchange of Forensic (Bio)information. In G. Bruinsma \& D. Weisburd (Eds), Emerging Issues in International Forensic Bioinformation Exchange, 5302-5313. New York: Springer. https://doi.org/10.1007/ 978-1-4614-5690-2.

McCartney, C., Williams, R., \& Wilson, T. (2010). The Future of Forensic Bioinformation - Executive Summary. University of Leeds.

McCartney, C., Wilson, T., \& Williams, R. (2011). Transnational exchange of forensic DNA: viability, legitimacy, and acceptability. European Journal on Criminal Policy and Research, 17(4), 305-322. https://doi.org/10.1007/s10610-011-9154-y.

Misa, T.J. \& Schot, J. (2005). Inventing europe: technology and the hidden integration of Europe. History and Technology, 21(1), 1-19. https://doi.org/10.1080/ 07341510500037487.

Murphy, E. (2010). Relative doubt: familial searches of DNA databases. Michigan Law Review, 109(3), 291-348.

Murphy, E. (2018). Law and policy oversight of familial searches in recreational genealogy databases. Forensic Science International, 292, e5-e9. https://doi.org/10.1016/ j.forsciint.2018.08.027.

Norris, C. \& Armstrong, G. (1999). The Maximum Surveillance Society: The Rise of CCTV. Oxford: Berg Publishers.

Pimentel, I. (2007). A História da PIDE. Lisbon: Círculo de Leitores.

Prainsack, B. \& Aronson, J. (2015). Forensic genetic databases: ethical and social dimensions. International Encyclopedia of the Social \& Behavioral Sciences, 9, 339 345. https://doi.org/10.1016/B978-0-08-097086-8.82062-0.

Prainsack, B. \& Toom, V. (2010). The Prüm regime. Situated dis/empowerment in transnational DNA profile exchange. British Journal of Criminology, 50(6), 11171135. https://doi.org/10.1093/bjc/azq055.

Prainsack, B. \& Toom, V. (2013). Performing the union: the Prüm decision and the European dream. Studies in History and Philosophy of Biological and Biomedical Sciences, 44(1), 71-79. https://doi.org/10.1016/j.shpsc.2012.09.009.

Quinlan, A. (2020). The rape kit's promise: techno-optimism in the fight against the backlog. Science as Culture, 1-25. https://doi.org/10.1080/09505431.2020.1846696.

Ramzy, A. \& Buckley, C. (2019, November 16). 'Absolutely no mercy': leaked files expose how china organized mass detentions of Muslims. The New York Times, 1-34. https:// www.nytimes.com/interactive/2019/11/16/world/asia/china-xinjiang-documents.html.

Reed, K. \& Syndercombe-Court, D. (2016). A comparative audit of legislative frameworks within the European Union for the collection, retention and use of forensic DNA profiles. EUROFORGEN-NoE. London. www.euroforgen.eu/fileadmin/web 
sites/euroforgen/images/Dissemination_Documents/WP4/Reed_and_Syndercombe_ Court_2016_Legal_Audit.pdf.

Ribeiro, M. da C. (1995). A Polícia Política no Estado Novo, 1926-1974. Lisbon: Editorial Estampa.

Richardson, S. (2017). China: minority region collects DNA from millions private information gathered by police, under guise of public health program. Humans Rights Watch.

Rothstein, M.A. \& Talbott, M.K. (2006). The expanding use of DNA in law enforcement: what role for privacy? The Journal of Law, Medicine and Ethics, 34(2), 153164. https://doi.org/10.1111/j.1748-720X.2006.00024.x.

Ryan, A. (2016). Comparative procedural traditions: Poland's journey from socialist to 'adversarial' system. The International Journal of Evidence \& Proof, 20(4), 305-325. https://doi.org/10.1177/1365712716655169.

Samuel, G. \& Kennett, D. (2020). The impact of investigative genetic genealogy: perceptions of UK professional and public stakeholders. Forensic Science International: Genetics, 48, 1-9. https://doi.org/10.1016/j.fsigen.2020.102366.

Samuel, G. \& Prainsack, B. (2018). Forensic DNA phenotyping in Europe: views "on the ground" from those who have a professional stake in the technology. New Genetics and Society, 38(2), 119-141. https://doi.org/10.1080/14636778.2018. 1549984.

Santos, F. \& Machado, H. (2017). Patterns of exchange of forensic DNA data in the European Union through the Prüm system. Science \& Justice, 57(4), 307-313. https:// doi.org/10.1016/j.scijus.2017.04.001.

Santos, F., Machado, H., \& Silva, S. (2013). Forensic DNA databases in European countries: is size linked to performance? Life Sciences, Society and Policy, 9(12), 113. https://doi.org/10.1186/2195-7819-9-12.

Skinner, D. (2013). "The NDNAD has no ability in itself to be discriminatory": ethnicity and the governance of the UK national DNA database. Sociology, 47(5), 976-992. https://doi.org/10.1177/0038038513493539.

Skinner, D. (2018a). Race, racism and identification in the era of technosecurity. Science as Culture, 29(1), 77-99. https://doi.org/10.1080/09505431.2018.1523887.

Skinner, D. (2018b). Forensic genetics and the prediction of race: what is the problem? BioSocieties, 15, 329-349. https://doi.org/10.1057/s41292-018-0141-0.

Sperling, S. (2008). Converting ethics into reason: German stem cell policy between science and the law. Science as Culture, 17(4), 363-375. https://doi.org/10.1080/ 09505430802514919.

Suter, S.M. (2010). All in the family: privacy and DNA familial searching. Harvard Journal of Law \& Technology Volume, 23(2), 309-399. http://jolt.law.harvard.edu/a rticles/pdf/v23.2/23HarvJLTech309.pdf.

Thomas, L. (2006). Nothing to hide, something to fear?: the use of partial DNA matching in criminal investigations. Journal of Law, Information and Science, 17, $72-93$.

Toom, V. (2012). Bodies of science and law: forensic DNA profiling, biological bodies, and biopower. Journal of Law and Society, 39(1), 150-166. https://doi.org/10.1111/j. 1467-6478.2012.00575.x.

Toom, V. (2018). Cross-border exchange and comparison of forensic DNA data in the context of the Prüm Decision. Civil liberties, Justice and Home Affairs. Parliament's Committee on Civil Liberties, Justice and Home Affairs and Policy Department for Citizen's Rights and Constitutional Affairs. European Parliament, Brussels. 
Toom, V., Wienroth, M., M'charek, A., Prainsack, B., Williams, R., Duster, T., Heinemann, T., Kruse, C., Machado, H., \& Murphy, E. (2016). Approaching ethical, legal and social issues of emerging forensic DNA phenotyping (FDP) technologies comprehensively: reply to 'Forensic DNA phenotyping: predicting human appearance from crime scene material for investigative purposes' by Manfred Kayser. Forensic Science International: Genetics, 22, e1-e4. https://doi.org/10.1016/j.fsigen.2016.01.010.

Transparency International. (2019). Corruption Perceptions Index 2019, 1-29. Transparency International - the global coalition against corruption. Berlin. www.transpa rency.org/cpi2019?/news/feature/cpi-2019.

Tutton, R. (2011). Promising pessimism: reading the futures to be avoided in biotech. Social Studies of Science, 41(3), 411-429. https://doi.org/10.1177/0306312710397398.

Tutton, R., Hauskeller, C., \& Sturdy, S. (2014). Suspect technologies: forensic testing of asylum seekers at the UK border. Ethnic and Racial Studies, 37(5), 738-752. https:// doi.org/10.1080/01419870.2013.870667.

Tutton, R. \& Levitt, M. (2010). Health and Wealth, Law and Order: Banking DNA Against Disease and Crime. In R. Hindmarsh \& B. Prainsack (Eds), Genetic Suspects: Global Governance of DNA Profiling and Databasing, 85-104. Cambridge: Cambridge University Press.

Wee, S.-L. (2019, February 21). China uses DNA to track its people, with the help of American Expertise. The New York Times, 1-9. www.nytimes.com/2019/02/21/busi ness/china-xinjiang-uighur-dna-thermo-fisher.html.

Wee, S.-L. (2020, June 17). China is collecting dna from tens of millions of men and boys, using U.S. Equipment. The New York Times, 1-6. https://nyti.ms/2N7xBHa.

Wienroth, M. (2018). Governing anticipatory technology practices. Forensic DNA phenotyping and the forensic genetics community in Europe. New Genetics and Society, 37(2), 137-152. https://doi.org/10.1080/14636778.2018.1469975.

Wienroth, M. (2020). Socio-technical disagreements as ethical fora: Parabon NanoLab's forensic DNA Snapshot ${ }^{\mathrm{TM}}$ service at the intersection of discourses around robust science, technology validation, and commerce. BioSocieties, 15(1), 28-45. https://doi.org/10.1057/s41292-018-0138-8.

Wienroth, M., Morling, N., \& Williams, R. (2014). Technological innovations in forensic genetics: social, legal and ethical aspects. Recent Advances in DNA and Gene Sequences, 8(2), 98-103.

Williams, R. \& Johnson, P. (2004). "Wonderment and dread": representations of DNA in ethical disputes about forensic DNA databases. New Genetics and Society, 23(2), 205-223. https://doi.org/10.1080/1463677042000237035.

Williams, R. \& Johnson, P. (2008). Genetic Policing: The Use of DNA in Criminal Investigations. Cullompton: Willan Publishing. http://dx.doi.org/10.4324/9781843925576.

Williams, R. \& Wienroth, M. (2014a). Ethical, social and policy aspects of forensic genetics: A systematic review, 1-81. EUROFORGEN-NoE. http://nrl.northumbria. ac.uk/id/eprint/16313/1/Forensic_Genetics_ELSA_Review_Williams_Wienroth.pdf.

Williams, R. \& Wienroth, M. (2014b). Public perspectives on established and emerging forensic genetics technologies in Europe: a preliminary report, 1-46. EUROFORGENNoE.

Wilson-Kovacs, D. (2014). "Clearly necessary", "wonderful” and "engrossing"? Mass observation correspondents discuss forensic technologies. Sociological Research Online, 19(3), 161-176. https://doi.org/10.5153/sro.3375. 


\title{
3 Transnational genetic surveillance in the $\mathbf{E U}$
}

\author{
The case of the Prüm system
}

\section{Introduction}

Criminal DNA databases are typically presented as an almost failsafe tool to identify individuals and match traces found at crime scenes with a suspect's profile (Lynch et al., 2008), and increasingly seen as a crucial tool for enhancing transnational police and judicial cooperation for the control of crime in the European Union (EU) (Amelung, Granja \& Machado, 2020; Toom, 2018; Toom, Granja \& Ludwig, 2019). This chapter will address a particular form of genetic surveillance in the EU emerging from the so-called Prüm system - a technological system created for the reciprocal automated search and comparison of information on DNA profiles, fingerprints, and vehicle registration data among EU Member States. In this chapter, we solely focus on the transnational exchange of DNA data, on the basis of 37 interviews with 47 professionals in charge of operating the Prüm system conducted between 2016 and 2019, in 22 countries.

The aims of the Prüm system are directed towards stepping up cooperation between EU states in combating terrorism and cross-border crime (EU Council, 2008a, 2008b), therefore fitting in global tendencies of expanding surveillance. Because of its cross-jurisdictional nature, the Prüm system is a particularly highlighting example of how genetic surveillance for the governance of crime might operate in a context of assembling different national legislations, various models regarding the provision of forensic genetic services provision and the organization of laboratories, distinct DNA analysis methods, diverse criminal investigation and policing practices, and heterogeneous functioning of criminal justice systems within the different EU jurisdictions. In a system like the EU, where the constituent Member States retain full national sovereignty over matters of internal security, the role of the Prüm system in this critical domain is far from obvious or settled.

The Prüm system is an exemplary case of an EU techno-political project promoting integration in the area of security policies and that highlights how the techno-optimism contained in widespread and collectively held imaginaries (Quinlan, 2020; Tutton, 2020) are prevalent elements of genetic surveillance. On the one hand, the Prüm system outlines the power of "technological seduction,"

DOI: $10.4324 / 9780429261435-3$ 
and on the other, it is particularly illustrative of what Sheila Jasanoff and SangHyun Kim called sociotechnical imaginaries (Jasanoff \& Kim, 2009, 2015), to refer to collectively held and performed visions of desirable futures (or of resistance) supporting the advances in science and technology. According to Jasanoff, socio-technical imaginaries also entail "aspirational and normative dimensions of social order" (Jasanoff \& Kim, 2015, p. 5).

A particular historical and political context explains the emergence and development of events that prompted the optimistic sociotechnical imaginary leading to joint efforts to control transnational criminality in the EU, of which the Prüm system is an exemplary endeavor. In the aftermath of the Schengen Agreement that abolished border controls across a number of European countries, several EU Member States became increasingly concerned about transnational movements of people considered dangerous and, consequently, the growth of transnational crime (Broeders, 2007; Guild \& Geyer, 2008; Hufnagel \& McCartney, 2017). Although some technological systems were already in place to facilitate the exchange of data across-borders for the purpose of criminal investigation, such practices were conducted on an ad hoc basis (McCartney, Wilson \& Williams, 2011). A point was reached when pre-existing practices were no longer deemed sufficient, and the voices calling for a closer cooperation among police forces in EU made themselves increasingly heard (Luif, 2007).

In 2003 Otto Schily, Germany's Minister of the Interior, called for closer cooperation in justice and internal affairs with France, Belgium, and Luxembourg, at a time when a Police Centre was opened in Luxembourg by the four countries. As a response to a growing perception of the need to foster policing and judicial cooperation, in May 2005 government representatives from Austria, Belgium, France, Luxembourg, Germany, the Netherlands, and Spain came together in the small German town of Prüm to sign a treaty that set provisions for exchanging data regarding DNA, fingerprints, and motor vehicle information and which became known as the Prüm Convention. The preamble of the Convention stated that, considering the existing free movement of persons, EU Member States should:

Play a pioneering role in establishing the highest possible standard of cooperation, especially by means of exchange of information, particularly in combating terrorism, cross-border crime and illegal migration, while leaving participation in such cooperation open to all other Member States in the European Union.

(EU Council, 2005, p. 3)

In 2008 some of the provisions in the Prüm Convention were subsumed into police and judicial cooperation provisions in EU law by a Council Decision, commonly referred to as the Prüm Decisions (EU Council, 2008a, 2008b). Prüm Decisions made it mandatory for all EU Member States to join the pan-European network for the exchange of fingerprints, DNA profiles and motor vehicle information. It was decided that such data should remain the 
property of the Member State where it was collected, eliminating the need for a centralized database. In sum, this meant that all EU Member States that had not yet set up their own databases for DNA profiles, fingerprints, and vehicle data information were obliged to do so in order to make such data accessible to the relevant EU authorities. The latest report on the progress made in the implementation of the Prüm System in terms of DNA databases, dating from January 2021, indicates that there are 25 EU Member States in operational conditions (EU Council, 2021). The non-operational countries are Greece and Italy. Although the UK is no longer part of the report, DNA data exchange is not interrupted, as it is covered by the EU UK Trade \& Cooperation Agreement.

The first section of this chapter describes how the Prüm system operates modes of genetic surveillance for the governance of crime in the EU. The subsequent sections explore the views of forensic experts and members of law authorities involved in this transnational police and judicial cooperation aimed at fighting cross-border crime and terrorism. In particular, we are interested in understanding how expectations play a constitutive and performative role (Borup et al., 2006), or in other words, how technological innovations go hand in hand with expectations over their potential benefits, which, in turn fuel societal interest, mobilization of professional network and allocation of resources. Moreover, expectations are also tied to perceptions of risk, reflecting how particular groups of actors make sense, reflect, and act upon expectations, considering their particular professional positionings and work views (Konrad, 2006). Addressing the discourses of the professional groups who are in charge of operating the Prüm system through the lens of expectations also provide contextual ground for understanding how the techno-optimism (Quinlan, 2020) framing sociotechnical imaginaries might encounter support and/or resistance.

\section{The Prüm system's modus operandi}

Transnational DNA data exchange within the Prüm system works as follows: when a search is made in a national database for a DNA sample retrieved from a crime scene and no match is found, the Council Decision authorizes transmission and search of data in the national databases of other Member States (the so-called Step 1 of the Prüm system). A notification is then sent to the original Member State reporting the existence or absence of a positive hit. If a hit is identified, further requests for information are processed through the existing police or judicial channels (the so-called Step 2 of the Prüm system, which is governed by national law).

The EU regulation of the Prüm system stipulates that, for the purposes of supplying data, each Member State shall designate a National Contact Point (NCP), and the powers of the NCPs shall fall under the applicable national law. The NCPs in charge of complying with the technical standards for the exchange of DNA data information among Member States on a match/no- 
match basis are officially called Step 1 NCPs. Typically, these NCPs are forensic experts working in forensic genetics laboratories. The political scientists Barbara Prainsack and Victor Toom noted that the increasing importance given to DNA evidence in transnational cooperation within the EU Prüm system has led to shifts in epistemic authority within the criminal justice system. According to the authors, one of the implications of the Prüm system is the shift of epistemic authority centres away from criminal investigators to forensic scientists:

[The] current status [of forensic DNA technologies] as a gold standard in criminal investigation locates the production of crucial evidence for truthfinding in the laboratory of the forensic scientist. Thus, it is no longer the criminal investigator who is seen as the bearer of the decisive expertise for solving a crime, but the forensic scientist.

(Prainsack \& Toom, 2010, p. 1125)

The NCPs in charge of the requests for additional information through mutual assistance procedures are called Step 2 NCPs and are usually professionals with experience of police and judicial cooperation in transnational criminal investigations. While the forensic experts acting as Prüm NCPs for Step 1 could be the primary drivers of the technological infrastructure for circulating and validating DNA data, the professionals working as Prüm NCPs for Step 2 constitute what Didier Bigo calls "professionals of the management of unease" (Bigo, 2006a, p. 6). In other words, they are professionals whose field of action cuts across internal and external borders and whose work is embedded in a "new generative space of struggles between security professionals that produces common interests, an identical program of truth and new forms of knowledge" (Bigo, 2006a, pp. 14-15). Although these professionals do not share the same logic of experience or practice and their work does not converge in a single function (Bigo, 2006a, p. 7) they can form alliances that overstep national boundaries to reinforce the credibility of their assertions within a context in which they find themselves competing for the monopoly on legitimate knowledge (Bigo, 2006a, p. 8). In this sense, despite their internal diversity - which is as much professional as geographical (Bigo, 2006a, p. 15) - these professionals allegedly have expectations of creating a "consensual" epistemic community among EU police forces:

Their ambition is to assemble cells of openly available information, social-scientific data, and the techniques of police intelligence operations. This dream of a common and consensual epistemic community haunts the imagination of these professionals who conduct societal transformations at a distance - a geographical and temporal distance piloted by the logic of anticipation.

(Bigo, 2008, p. 101) 
Hence, the Prüm system involves the interaction of diverse professional practices, entailing both cooperation and coordination, but also conflicts and struggles for power (Machado \& Granja, 2018, 2019; Prainsack \& Toom, 2010; Toom et al., 2019). In the next section of this chapter, we outline the expectations raised by the Prüm system, emphasizing its complex and hybrid nature. One important aspect in our analysis is how expectations of professional groups operating the Prüm system on their daily activities combine "high expectations" with "low expectations" regarding the value and capability of transnational genetic surveillance in the EU. Since each country makes its own national digitalized archive of DNA profiles available for transnational exchange, the Prüm system is supported by the mass availability of DNA profiles associated with criminal identity archives, something unprecedented in the history of EU policing. This form of surveillance is of reconstructive nature: it relies on a technological apparatus that is legitimized by the rhetoric of automation, speed, and accuracy (Williams \& Johnson, 2004). In the next section we address the particular kind of expectations that are generative and performative of specific form of surveillance organised around an ideology of "European security" (Machado, Granja \& Amelung, 2020).

\section{Expectations raised by the Prüm system}

Over the years, the debates following the creation of the Prüm system, have to some extent served to polarize positions in the sense described by Elise Pieri, in which promoters of a technology tend to construct scenarios that describe its benefits, and opponents often project scenarios that highlight possible risks (Pieri, 2009, p. 1105). On the one hand, drivers of the system - mainly political actors in positions of power to enable the integration of the Prüm Convention system into EU acquis - have highlighted the Prüm system's potential towards fostering closer transnational cooperation in the fight against crossborder crime and terrorism, speeding up the exchange of information and raising efficiency in the detection and solving of transnational crime (Amankwaa, 2019; Sallavaci, 2017; Santos, 2017; Wilson, 2016). The drivers of the Prüm system, therefore, envisioned a future in which the implementation of a techno-scientific infrastructure would be able to surpass and override the significant differences between EU countries in terms of legislation, type of criminal justice system and human and economic resources. The technooptimism and "aspirational component" of the Prüm system - its sociotechnical imaginary - derived from the idea that "rationales and objectives are futureorientated" and work to "prevent crimes, produce state security and public safety" (Toom et al., 2019; Wienroth, 2020).

On the other hand, critical voices, emerging mainly from academia and civil society stakeholders and organizations, have been pointing out the potential risks posed by the implementation and operation of the Prüm system. Some of the topics debated have been, for instance, the tensions and frictions created owing to national differences in operational, legal, and 
ethical policies, including privacy safeguards, could raise civil rights concerns (Machado \& Granja, 2018; McCartney, 2014; Prainsack \& Toom, 2010, 2013; Toom, 2018). Other discussed topics include issues related to lack of transparency and accountability of the Prüm system (McCartney et al., 2011; Toom, 2018; Toom et al., 2019; Wilson, 2016).

During our empirical study with professional groups directly involved in the operations of the Prüm system we could notice that the term "sociotechnical imaginaries" (Jasanoff \& Kim, 2015) was rather useful for analyzing policy debates and the discourses of political social actors (the macro level of reality). Applied to this topic, the term both encapsulates the high expectations for the value of the Prüm system as an asset in fostering transnational collaboration to monitor and fight crime in the EU, as well as the critical views concerned with its risks. However, the concept of sociotechnical imaginaries was less useful for understanding and interpreting the discourses at a meso and micro-level. In our view, a more productive way to understand the meanings attributed by members of the professional and epistemic communities in charge of the daily operations of the Prüm system, is to grasp their meanings as means of performing collective expectations, in the terms set out by Kornelia Konrad. The author defines the concept of collective expectation in the following way:

Collective expectations are not only shared by a large number of actors, they are part of a generalized and taken-for-granted social repertoire. They have become a depersonalized social construction - a fait social. Actors refer to them and take them into account and assume that other actors share these expectations or, at least, that they are aware of them and will also take them into account.

(Konrad, 2006, p. 431)

According to Konrad (2006), expectations can be very widely accepted for a period of time, both by supporters of a new technology and also critical voices faced with the inevitability of a particular technology's development. The author points out that the dynamics of expectations must be understood as a social process. On the one hand, collective expectations play a central role in creating the necessary momentum for innovation processes and in the coordination of heterogeneous actors. On the other hand, they could also be highly problematic, when hype-cycles turn into disappointment phases (Konrad, 2006, p. 430).

We aim to address expectations for the Prüm system as a social process, through which the various actors relate, not only to their own, but also to other's expectations. Conceiving expectations as a social process allows us to understand how collective expectations are able to draw together a large number of highly heterogenous actors, and how expectations are strategically distributed according to the specific positioning of actors and their specific situatedness. In the next sections of this chapter, we explore the expectations 
for the Prüm system as revealed by the two distinct professional groups that operate it - the NCPs conducting laboratory work and the NCPs working within law enforcement international cooperation forces (the so-called Prüm Step 1 and Prüm Step 2, respectively).

We shall address the expectations for the Prüm system performed both by forensic practitioners and police professionals as a product of social interaction. We argue that the expectations of professionals working in the laboratory and professionals working in criminal investigation might be widely shared and thereby serve as coordination devices. At the same time, expectations might also vary according to the situatedness of particular positionings of professional groups in the complex networks, social relations and events occurring in the transnational circulation of DNA data within the Prüm system of policing and judicial cooperation. Thus, the views, held by the two distinct groups of professionals on the Prüm system, reveal an "interpretative flexibility" (Konrad, 2006, p. 436), or in other words, "the results of technological projects are interpreted in the light of the same expectations they are supposed to "validate," strategically oriented to protect specific area of expertise and the allocation of resources.

\section{Prüm in the laboratory}

European scientists and forensic experts follow an elaborate trajectory in the creation and implementation of standards, protocols and laboratorial practices for DNA analyses across Europe. This tradition, coined by Barbara Prainsack and Victor Toom as "forensic technocracy" (Prainsack \& Toom, 2010, p. 1125), was particularly relevant in the implementation of the Prüm system, as it enabled the establishment of procedures and infrastructures conducive to data exchange.

In the aftermath of the Prüm Decisions, the "Working Party on Data Protection and Information Exchange - DAPIX" was created to overview, implement and support the tasks and procedures involved in the transnational exchange of information. This group developed significant work in terms of standardization and harmonization of scientific and technical procedures between laboratories based in different countries. As a result, NCPs working in laboratories, usually in charge of Step 1 procedures, tend to emphasize the Prüm system's potential in enabling to streamline the adoption of international standards, enabling the harmonization of forensic DNA analysis procedures, and supporting further collaboration among different countries.

Since Prüm started, we had more discussions about inclusion rules, matching rules, reporting rules (...) We now know that we have international matches and we need to be more harmonized. (...) If we didn't have Prüm, each country would be completely separated from the others, they do on their own, and we wouldn't need to discuss, really.

(Interview I01) 


\section{Genetic Surveillance and Crime Control}

Thus, it becomes clear that such professionals reproduce the kinds of expectations that rely on the ability of techno-scientific standardization to achieve increased transnational collaboration and interoperability. However, such a scenario brings with it the increased risks of false positives (invalid matches), owing to the increment in the volume of profiles available for comparison. Actually, this problem had already been pointed out and discussed in the early stages of the Prüm system's implementation (McCartney, 2014; Van der Beek, 2011). What the NCPs working with Step 1 call attention to is the fact that the potential for the occurrence of false positives is further increased by national variability in terms of scientific, infrastructural, human, and economic resources with a direct influence on how DNA analysis is conducted. More particularly, some forensic practitioners express strong skepticism and reservations about their foreign colleagues' capacity to ensure that no false matches are communicated to criminal investigators and/or to judicial entities (Machado \& Granja, 2018).

We have good procedures in place to make sure that we first find out if it is a good match before it is reported to the authorities. I think that in [my country] there is no risk of a false positive match being used for legal actions. But I am not sure whether this is also the case in other countries.

(Interview A01)

One other topic currently referred by NCPs working in laboratories, concerns the inexistence of feedback on the matches produced within Prüm. Usually, after reporting a match, these professionals do not receive any feedback on whether the match was followed-up and whether it led to a conviction. Thus, NCPs working in laboratories do not have a proper channel that would allow them to assess whether their expectations over Prüm's potential to step up crime-fighting at a transnational level are substantiated, for instance, by conviction rates.

We've actually had no feedback on what the benefits have been, if there have been many cases solved; we do not know, because we don't get any feedback. (...) We realized this and discussed it last year with our contact point in the police, but until now there has been no action. We thought of registering every case from the start, where we would be responsible for initiating the register and then hand over the information for them to fill in the resulting outcome - whether it was ignored, becoming outdated, whether it led to a false positive in the investigation...

(Interview B01)

There is a substantive body of literature showing that expectations are usually subjected to alternating cycles of hype and disappointment (Borup et al., 2006; Konrad, 2006). That is, in the early stages, promises are inflated, and such early hype eventually gives way to disillusionment (Brown, Rip, \& 
Van Lente, 2003). Although this is not exactly the case with NCPs working in Prüm Step 1, insofar as they recognize that the Prüm system did indeed foster transnational collaboration, there is an overall sense among participants that there is a lack of "hard facts" (Konrad, 2006, p. 436). In other words, there is a shortage of results that can be measured against expectations, thereby attesting to the system's efficacy or lack thereof. Professionals working in Prüm Step 1 argue that the number of hits obtained through Prüm should constitute a suitable "hard fact" in such an assessment and, consequently, to validate the underlying expectations raised by the system. Such stances are linked to widely discussed issues around the shortage of information on the overall effectiveness and efficiency (Santos \& Machado, 2017; Taverne \& Broeders, 2015) as well as a variety of issues concerning the Prüm system's lack of transparency and accountability (McCartney et al., 2011; Toom, 2018; Toom et al., 2019; Wilson, 2016).

Our interviews with Prüm NCPs for Step 1 revealed an expectation that faster and more effective criminal investigation could be achieved by performing DNA comparisons with several countries simultaneously. A few examples of this optimistic tone towards the potential benefits of transnational DNA data for criminal investigation are expressed in the following excerpts:

The benefit is that you can find very quick matches from travelling people who commit crimes.

(Interview U02)

The benefits are clear, we all send every DNA profile that is taken from a crime scene in [country], or a suspect, to all the other Prüm countries; that way there is a better chance to get much more hits, compared with only doing the comparison nationally.

(Interview O02)

According to interviewees, the Prüm system is also beneficial to the protection of national sovereignty, as it allows countries to maintain national data ownership and custody while at the same time enabling the DNA data contained in the national criminal databases to be shared at a transnational level. In the words of one participant:

Through Prüm we can exchange DNA profiles very quickly without relinquishing custody of our own data.

(Interview W02)

In view of this, the narratives of NCPs for Step 1 reproduce and consolidate (at least some of) the Prüm system's "collective expectations," underlining the system's role in fostering the stepping-up of cross border cooperation, while still maintaining ownership over national data. However, the kind of 
performative narratives that highlights the fulfillment of expectations about the Prüm system, coexist with a scenario in which differentiation across countries is reproduced, creating uncertainties. The same decentralization that enables the maintenance of data ownership also implies that the interoperability of DNA databases exists in a setting of national differentiation (Santos, 2017). Such a framework allows autonomy at a local level to choose what data to make available for transnational exchange. As noted by Didier Bigo "in effect the exchange of data in the form of the interoperability of systems does not forcibly imply making a common all data, and even less common categories of collection" (Bigo, 2006b, p. 3). Within the Prüm system, this implies, for instance, that while Malta allows access to all data categories (convicted, suspects, crime stains, victims, unidentified persons, unidentified human remains, and missing persons) Portugal only exchanges the following data categories: convicted and crime stains (EU Council, 2021). Expectations that marked initial debates, about complete interoperability within EU, are therefore counteracted by the current Prüm situation, since each country has the autonomy to define which data categories to exchange. Some participants consider that it hampers the Prüm system's full potential, since it is not consistent with a uniform data exchange across EU countries. The following interview excerpt reflects the disappointment related to participants in the Prüm system who are not fully collaborating towards fulfilling the aims of this transnational network of DNA data exchange:

Those countries are not sending us their person stains. (...) So, I think we need to coordinate ourselves and everybody should be doing the same thing.

(Interview W02)

In addition to the level of autonomy countries are allowed as to which data categories they exchange, several interviewees also acknowledged that the incomplete connections currently displayed by the Prüm system were inconsistent with initial expectations about full implementation soon after the Decisions. August 2011 was the deadline set for all EU countries to comply with Prüm Decisions. However, most countries were unable to comply for a variety of different reasons (McCartney et al., 2011; Prainsack \& Toom, 2013). For example, difficulties arising in securing the necessary political majorities to adapt national laws to the provisions of the Prüm system; conflicts between stakeholders over the attribution of responsibilities for the Prüm system; and human and financial resources (Prainsack \& Toom, 2013; Töpfer, 2011). Moreover, Italy, Greece, Ireland, and Malta faced additional constraints, as they did not yet have a DNA database nor specific legislation when the Prüm Decisions were adopted (Toom et al., 2019).

In addition to a protracted period of implementation (currently, there are still two non-operational countries: Greece, and Italy), the level of connections is still highly variable across countries. That is, having an operational 
status within the Prüm system does not necessarily imply exchanging data with all operational countries. The available data shows that while the Netherlands and Austria are connected to 23 countries, Bulgaria is exchanging DNA data with 13 countries and Ireland with five countries (EU Council, 2021). According to interviewees, such a scenario could pose serious risks related to the loss of important data. In the words of a participant:

Several countries are not linked (...) and many police officers (...) expect that as soon as they make an entry in the database, it will be automatically checked everywhere in Europe, so if they do not get a hit they take it as meaning that there is no DNA hit in the whole of Europe, which is the wrong interpretation.

(Interview O02)

The Prüm system's current state of connections, therefore, evinces that initial expectations overemphasized the simplification that this techno-scientific solution would allow, while undervaluing the potential obstacles raised by political, social, and legal issues. Despite the challenges faced by the Prüm system, participants in this study placed expectations on its further expansion. Besides mentioning the need to make all countries operational, several interviewees were also in favor of turning the Prüm system into a "global network" - that is, including non-EU countries. As expressed by one of the interviewees:

Well, I think that the Prüm network will be growing and growing, new countries will be operational, and they will be establishing new connections. So, it will be one big network, maybe a global network.

(Interview G05)

The expectations of NCPs for Step 1 reveal a complex and nuanced scenario. The "collective expectation" of stepping up transnational collaboration was the basis for enabling the implementation of the Prüm system. According to NCPs who work in laboratories, that "collective expectation" is indeed being fulfilled, since the quick exchange of data allows for an enhanced system for transnational collaboration. NCPs for Step 1 are thus engaged with a legitimization work that, besides highlighting the Prüm system's beneficial outcomes, also incites further expansion of the system.

However, such a perspective coexists with a perception of the challenges posed by the overemphasis of initial expectations over Prüm and the ability of techno-scientific solutions to generate interoperability within such a differentiated scenario. NCPs working in laboratories also underline how initial expectations about the full implementation of the Prüm system are thwarted by national autonomy to define the type of data categories exchanged; the non-operational status of some countries, owing to multiple social, political and economic issues; and the highly differentiated level of connections among 
states within the Prüm system. It is therefore clear how the genetic surveillance envisioned in the early stages faced daily and pervasive challenges entailed in such a system. Namely, issues of national sovereignty, data ownership, as well as social, legal, ethical, political, and economic challenges (Machado \& Granja, 2018, 2019; Toom et al., 2019).

\section{Prüm in international cooperation of law enforcement}

For the international police professionals (NCPs for Step 2), the Prüm system constitutes an additional tool, whose enhancing of police "scientification" (Innes, Fielding \& Cope, 2005), enables to streamline communications between international partners, thereby intensifying international collaboration (Machado \& Granja, 2019). In the words of one of the NCPs for Step 2:

When you do an investigation with the international case officers, you can complete a puzzle. You could not do that before (...). Prüm gives us the tools to do this.

(Interview U01)

The Prüm system is also perceived by these professionals as a reinforcement of the principle of availability, obliging Member States to share certain types of information available to domestic authorities with their counterparts in other Member States. As expressed by one of the participants:

Information is now more available. There is a proper channel for issues related to DNA databases.

(Interview X02)

Thus, according to these narratives it is clear that "collective expectations" regarding Prüm's potential to step up transnational collaboration are being met. Nonetheless, as outlined by Didier Bigo (2006b) the principle of availability can be divided into two sub-principles: "visibility" and "legibility." "Visibility" is ensured within Prüm by allowing to know whether the information is available in another country. However, knowing that information exists is not necessarily tantamount to access which, as Bigo argues, describes the sub-principle of "legibility" (Bigo, 2006b). This difference is particularly relevant within Prüm and clearly expresses the challenges faced by law enforcement officers cooperating internationally in Prüm Step 2. While Prüm Step 1 entails the automated exchange of DNA profiles according to predefined channels, within Step 2 the scenario is different. Following a DNA hit, several case scenarios might occur, depending on the countries requesting or providing data: some countries provide the non-genetic information associated to the profile immediately after a match, others ask for additional analysis of the DNA profile, and some countries only provide information through a judicial rogatory commission (Machado \& Granja, 2019). This 
means the level and speed of access to the information within the Prüm system is highly variable.

One of the factors contributing significantly to variable procedures within Step 2 is the diversity of domestic provisions regarding the custody of national DNA databases throughout Europe. In the vast majority of countries using the Prüm system, custody over the National Forensic DNA Database belongs to the Interior Ministry (otherwise designated Ministry of Internal Affairs or Ministry of Home Affairs) - a department of government typically responsible for policing, emergency management, national security, and immigration. However, in countries such as Belgium, the Netherlands, Portugal, and Sweden, custody of the National DNA Database belongs to the Ministry of Justice. Usually, this Ministry has specific duties connected with organizing the justice system, overseeing public prosecutors and maintaining the legal system and public order. Police forces and judicial authorities have different perspectives and follow different rationales regarding crime control: police agencies work with investigative clues and intelligence (Innes et al., 2005), while prosecutors are mainly interested in adducing evidence. Consequently, diverging practices emerge when submitting or responding to international legal assistance procedures within Prüm (Machado \& Granja, 2019).

Generally, Step 2 NCPs who are police professionals already have an established tradition of cooperation at the international level, grounded on the principle of reciprocity and based on informal and interpersonal interactions. This implies that, generally, information is easily accessible within the collaboration between two police agencies. Inversely, the judicial authorities are viewed by professionals involved in police cooperation as a professional group operating mainly through formal and bureaucratic networks at a national or local level (Machado \& Granja, 2019). Expectations about the swiftness of data exchange are therefore only partially fulfilled within Prüm as differentiated practices emerge, ranging from an informal and quick data exchange to bureaucratic and lengthy procedures that include the emission of letters rogatory requesting information access. The following quotation is a good illustration of the frustration felt by the NCPs for Step 2:

It's a pity [that some countries] (...) are obliged to go through the judicial network. Because the exchange is really slow, and most of the time incomplete, compared with what we can do in the police.

(Interview H02)

As described previously, NCPs working in Step 1 (experts working in forensic laboratories) call for the need to have more information on the "hard facts" of the Prüm system. That is, knowing whether DNA hits are (or not) followed up by criminal investigations and their outcomes within the criminal justice system. Inversely, NCPs working in Step 2 tend to be highly critical of what they perceive as being an "excessive focus" on DNA hits. Their view is that forensic DNA data is merely one piece of information that might, or might 


\section{2}

Genetic Surveillance and Crime Control

not, become significant in a given criminal case (Machado \& Granja, 2019). Consequently, professionals working in criminal investigation argue that the efficacy of Prüm should not be measured according to the number of matches resulting in criminal convictions. In the words of one of the participants:

In my opinion, it's a mistake, to measure the efficiency of Prüm exclusively by comparing how many cross-checks we did and how many people were sentenced. (...), the feeling I get is that at the European level, sometimes they want to have, how should I say this, stupid things: thousands of cross-checks, thousands of people in jail. It doesn't work like that.

(Interview H02)

Professionals working in law enforcement international cooperation, therefore, argue for a broader interpretation of the Prüm system's aims. In their view, Prüm matches are mainly useful to advance the gathering of intelligence for criminal investigation work, regardless of its outcome (Machado \& Granja, 2019). Consequently, they should not be used as "hard facts." As stated by the following participant, a DNA hit is not, the most important element of a criminal investigation within the Prüm system:

If I were the director of a lab, I might think: "OK, my procedure is of the highest quality, no chance of error, because when I have a hit it is $100 \%$ correct." But sorry, for this kind of solution I might just as well have a trained monkey in the laboratory.

(Interview M01)

Professionals involved in international police cooperation, therefore emphasize the importance of the work that must be done in order to assess whether a DNA hit is meaningful in a certain criminal case. As the following quotation shows, the interviewees are particularly clear in defining the procedures involved between obtaining a DNA hit on the basis of the Prüm exchange system and producing a conviction on the basis of that hit:

If we are talking about DNA exchange (...) Prüm helps to identify the person responsible for the crime. (...) it would not help you to secure that person's conviction (...) It is effective in identifying the suspect. (...) taking a person to trial takes more than [DNA data] ... for instance, you still have to prove that the DNA did not find its way there [the crime scene], let us say, by accident. Proving that a person identified by the system is responsible for the crime in question is still a lot of work.

(Interview F02)

For Prüm NCPs for Step 2, the DNA data exchanged between EU Member States must be analyzed and crossed with information from a wide range of 
sources, using a particular set of police skills and knowledge, in order to be considered intelligence that can (in)form actions concerning the how, when, why and against whom they take action (Innes et al., 2005). As highlighted by the following excerpts, for police professionals acting as NCPs for Step 2, the "Prüm hit" represents a starting point of the process. In order to turn it into meaningful and useful information (i.e., intelligence), the police must collect and make sense of the information that contextualizes a hit which might, or might not be actually valuable in policing practice:

Prüm is a small piece (...). We have to build so much more. That is how I see my role. Not just negotiating that little piece of information, I have to make sure that it works fully. So, the Prüm is not: "We have a hit, that is that." It is just the beginning; the hit must lead to a result (...) we must go all the way and hopefully we will put one person in prison.

(Interview U01)

We are not relying on the Prüm hit as the evidence. The Prüm hit is the intelligence to justify a particular course of action.

(Interview D04)

DNA data is mainly of strategic value to professionals involved in international police cooperation. The DNA hits generated within the Prüm system are viewed by these professionals as having a useful potential for identifying and pursuing links between a certain offence and a potential suspect. In addition, police professionals are extremely interested in establishing links between crimes, since this information might eventually allow to map networks of itinerant delinquency operating on a transnational level (Wilson, 2016). DNA hits within Prüm are thus seen as a type of information that might enable law enforcement agencies to construct intelligence (Innes et al., 2005) about when, where, and how crimes are being committed across borders, without necessarily requiring detection of the actual offenders in each instance (Sulca, 2017):

I think the value of DNA databases in helping us to understand offenses and their perpetrators in more types of crime is very powerful. If we do that across international boundaries it could provide a useful [tool].

(Interview D01)

Nowadays all of these criminal activities have no borders. (...) So, DNA could, at least, help to locate the person or check whether the person committed the same crime in different countries in Europe.

(Interview E02)

One of the most important expected benefits is the potential to maximize the information obtainable from the Prüm system, even if, after doing the 
follow-up work from the DNA hits, it might not lead to a viable line of investigation. As one of the interviewees explains:

Our police officers say: "We would like to get more hits and have the chance to dismiss some, not having to consider or follow up all of them, instead of just getting one hit and missing all the other ones." So, this is the philosophy of our police. They do not want to miss hits which might be positive hits in the end. (...) It is a sort of philosophy of getting hits you would like to have a little bit more work but not miss an opportunity.

(Interview O01)

What the interviewee calls the "philosophy of getting hits" therefore implies transferring to police work the decision on what might constitute valid, legitimate, and useful knowledge, rather than keeping it in the sphere of the forensic scientists in the laboratories. It also implies a strategy of crime control that actively reacts to the alleged shifting of power away from criminal investigators to forensic scientists, which was introduced by the Prüm system (Prainsack \& Toom, 2010). By arguing that the police should be in charge of assessing which hits should be followed up, the interviewees are substantiating the complexity and ambiguous nature of forms of scientification of police work, while, at the same time, protecting the autonomy and distinctiveness of police authority and expertise. An overview of diversity of expectations and perceived challenges according to positionings of NCPs is summarized in Table 3.1.

The collective expectation about the benefits emerging from stepping up transnational collaboration brought by the Prüm system is perceived by NCPs working in law enforcement agencies as having been fulfilled. Similarly, to the views expressed by the NCPs working in laboratories, the NCPs working in criminal investigation highlight the positive outcomes of the Prüm system and encourage its further development and expansion. However, this collective expectation coexists with specific expectations regarding the specificities of police work. The particular expectations of the Prüm NCPs for Step 2 create, advocate, and reinforce certain distinctions in relation to the work methods of other professionals also involved in transnational cooperation, such as the judicial authorities and forensic scientists. On the one hand, judicial authorities are perceived as a professional group operating mainly through formal procedures on a national or local level, lacking an experience and tradition of international cooperation. Thus, for instance, when police professionals need swift access to information to validate the importance of DNA data, the bureaucratic and time-consuming procedures of the judicial authorities tend to hinder such assessment. On the other hand, police professionals emphasize the need to moderate high expectations regarding the value and capacity of DNA data to support criminal investigations. As a result, they attempt to transfer decision-making concerning the potential validity and usefulness of data to police work rather than the work of the forensic scientists in the laboratories (Machado \& Granja, 2019). 
Table 3.1 Summary of expectations being met and challenges, according to different NCPs

\begin{tabular}{|c|c|c|}
\hline & Expectations being met & Challenges \\
\hline \multirow[t]{5}{*}{$\begin{array}{l}\text { Prüm in the } \\
\text { laboratory }\end{array}$} & $\begin{array}{l}\text { Harmonization of forensic } \\
\text { DNA analysis procedures } \\
\text { among different countries }\end{array}$ & False positives \\
\hline & $\begin{array}{l}\text { Foster transnational } \\
\text { collaboration }\end{array}$ & $\begin{array}{l}\text { Skepticism and reservations } \\
\text { over foreign colleagues' pro- } \\
\text { cedures for reporting matches }\end{array}$ \\
\hline & $\begin{array}{l}\text { Stepping-up of cross-border } \\
\text { cooperation, while still main- } \\
\text { taining ownership over } \\
\text { national data }\end{array}$ & Lack of "hard facts" \\
\hline & & $\begin{array}{l}\text { Non-consistent data exchange } \\
\text { across EU countries }\end{array}$ \\
\hline & & Incomplete connections \\
\hline \multirow[t]{2}{*}{$\begin{array}{l}\text { Prüm in interna- } \\
\text { tional cooperation of } \\
\text { law enforcement }\end{array}$} & $\begin{array}{l}\text { Intensify international } \\
\text { collaboration }\end{array}$ & $\begin{array}{l}\text { Different modus operandi of } \\
\text { police and judicial authorities } \\
\text { with custody of national } \\
\text { DNA databases }\end{array}$ \\
\hline & $\begin{array}{l}\text { Reinforcement of the princi- } \\
\text { ple of availability }\end{array}$ & $\begin{array}{l}\text { Excessive focus on DNA } \\
\text { matches to measure the effi- } \\
\text { ciency of the Prüm system }\end{array}$ \\
\hline
\end{tabular}

Source: Authors.

\section{Conclusion}

Since more than a decade has passed since the implementation of the Prüm system, this chapter allows us to understand how expectations constructed, performed, and circulated over the Prüm system have been articulated, adjusted, and stabilized over time (Hielscher \& Kivimaa, 2018). The expectations of forensic experts and members of law authorities involved in the Prüm network for transnational police and judicial cooperation aimed at fighting cross-border crime and terrorism feature complex dynamics of genetic surveillance. To use the concept of "sociotechnical imaginary," reveals how a European imaginary of security and role of the EU in the "Global War on Terror" is forming in the EU policy domain. This term is also useful for understanding how a "EU identity" is constructed in the envisioned politics of control and surveillance promised by the Prüm (Amelung et al., 2020). To address the collective and specific expectations of professional groups who are in charge, through their daily actions, of operating the Prüm network allows drawing attention to deep entanglements of technoscientific and political arrangements.

In this chapter, we considered the Prüm system as a clearly illustrative case study of how the specific expectations of epistemic communities of forensic 
experts and of members of law enforcement about the capacity and value of forensic DNA technologies and the exchange of DNA data at a transnational level play a constitutive and performative role that nourishes the dynamics of genetic surveillance for the governance of crime in the EU. These expectations reflect how particular groups of actors receive, interpret, and act in this context considering their particular professional positionings and work views. These different attitudes shed light on what Kornelia Konrad calls an "interpretative flexibility" (Konrad, 2006), governing how various actors relate, not only to their own expectations, but also to those of others. In our empirical case, interpretative flexibility operates as a two-sided phenomenon: on one side, collective expectations over the Prüm system are able to draw together a large number of highly heterogeneous actors, based on the perception of the benefits of expanding the system of cooperation speeding up exchange of DNA data and valuable information for criminal investigation, increasing accuracy and reliability. On the flipside, expectations are strategically distributed according to the specific positioning of actors and their particular situatedness in the spaces of the technological apparatus sustaining the idea of a "European security."

We have also analyzed what Mads Borup and colleagues (2006, p. 286) describe as processes by which expectations are foundational in vertical, horizontal and temporal coordination. The analysis undertaken in this chapter shows these dynamics in a particularly illustrative way. Vertical coordination is illustrated by Prüm system's mediation between different scales: namely, at a macro level, evinced by the EU; at a meso level, here represented by national diversity; and, finally, at a micro level, comprising the variable practices found within national contexts. Horizontal coordination is underscored by the coexistence of different communities within Prüm's daily activities, involving both forensic scientists and law enforcement agents. Finally, our chapter also reflects upon temporal coordination as it looks into how expectations have been articulated, adjusted, and stabilized, since the implementation of the system, more than a decade ago.

The relevance of the genetic surveillance disseminated by the Prüm system has been maintained over time by actively managing the expectations associated with it, namely by safeguarding particular expectations and disregarding others. This has been possible, first, because of the standardization of technoscientific procedures across countries, allowing for automated exchange of data in the first step of the Prüm system. The harmonization and standardization of procedures among professionals based in different countries has consolidated expectations regarding the identification of suspects across EU and enhanced techno-scientific harmonization in ways that safeguard Prüm's promised prospects. Second, by sustaining transnational DNA data exchange, even when criteria for assessing the validity of a match has become highly disputed, owing to the occurrence of false negatives and uncertainties about procedures followed by counterparts in other countries. Third, in order not to threaten countries' custody over data, Prüm subsists in a regime that brings together diverse 
epistemic cultures and a shifting set of criminal justice systems supporting the circulation of information. Expectations over harmonized interoperability across EU have, therefore, been minimized in favor of maintaining data exchange in a scenario marked by differentiated procedures across countries, both in Step 1 and 2 of Prüm.

Thus, the expectations over Prüm work as an ongoing device of legitimization that emphasizes Prüm's role in stepping up transnational collaboration, upholding its "global" expansion, while simultaneously playing down the scrutiny of its promises concerning crime control and detection (Santos \& Machado, 2017; Toom et al., 2019), as well as the possibility of future alternative means to deal with cross-border crime and terrorism.

Although expectations about the interoperability of EU databases have stabilized over time, we have witnessed the persistence of some reservations. Namely, full implementation of the Prüm system across all EU countries has not yet been achieved, and issues of transparency, and therewith accountability, remain problematic, leading to tensions between the different epistemic cultures that support the circulation of information. Such disputes are mainly grounded in conflicting views about how to use and make sense of DNA data within the Prüm system, about its expected efficacy, and disagreements about the implications of genetic surveillance in its diverse and ambiguous manifestations.

Elsewhere, in a work with our colleague Nina Amelung, we explored how different national political cultures implement or resist the idea of Europe's technological and political integration through borderless data exchange (Amelung et al., 2020). We argued that it is important to portray and critically examine the complex, multi-layered, and hidden processes of integration and disintegration of Europe highlighted by the linking and delinking of technological infrastructures between nation states, in a process mediated by diversity of legislation, infrastructures, organizational principles, and nationhood. In this chapter, we further contribute for the critical examining of the diverse and less visible processes of expectations of forensic experts and professionals working in international police and judicial cooperation, to reflect on its implications for the interplay between utopian and dystopian views on the programmatic security policy agenda of EU, oriented implementation of information systems in which genetic surveillance is expected to play a considerable role.

The future of the Prüm system, as an EU political project materialized by supra-state institutions, is still uncertain. Nonetheless, there have been indications that amendments could be introduced in the near future, such as: exchanging DNA data with non-EU countries; harmonization of practices of using DNA matches for supporting criminal investigation in the different EU jurisdictions; modernization of Prüm's infrastructure and technology; and the exchange of additional forensic modalities, namely facial recognition data. As such, the so-called "next generation Prüm" is characterized by expansion and convergence (Toom, 2018; Toom et al., 2019) by which technological section persist and new horizons for function creep (e.g., using technology to fulfill unforeseen functions) are opened up. Therefore, there is the need, on the one 
hand, to conduct studies that mitigate the overall scarcity of information about how the Prüm regime contributes to the EU's criminal justice systems (Toom et al., 2019). On the other hand, the further expansion of the Prüm system must be accompanied by an oversight mechanism that effectively evaluates outcomes and options alike in terms of justice, as well as safeguards for the principles of equality and privacy, and fosters engagement with accountability, public trust, and democracy.

\section{References}

Amankwaa, A.O. (2019). Trends in forensic DNA database: transnational exchange of DNA data. Forensic Sciences Research, 5(1), 8-14. https://doi.org/10.1080/ 20961790.2019 .1565651$.

Amelung, N., Granja, R., \& Machado, H. (2020). Modes of Bio-Bordering: The Hidden (Dis) integration of Europe (1st ed.). London: Palgrave Macmillan. https:// doi.org/10.1007/978-981-15-8183-0.

Bigo, D. (2006a). Security, Exception, Ban and Surveillance. In D. Lyon (Ed.), Theorizing Surveillance - The Panopticon and Beyond (46-68). Cullompton: Willan. https://doi. org/10.4324/9781843926818.

Bigo, D. (2006b). The Principle of Availability of Information. European Parliament, Brussels.

Bigo, D. (2008). EU Police Cooperation: National Sovereignty Framed by European Security? In E. Guild \& F. Geyer (Eds), Security Versus Justice? Police and Judicial Cooperation in the European Union (91-108). Aldershot: Ashgate.

Borup, M., Brown, N., Konrad, K., \& Van Lente, H. (2006). The sociology of expectations in science and technology. Technology Analysis \& Strategic Management, 18 (3-4),285-298. https://doi.org/10.1080/09537320600777002.

Broeders, D. (2007). The new digital borders of Europe: EU databases and the surveillance of irregular migrants. International Sociology, 22(1), 71-92. https://doi.org/ 10.1177/0268580907070126.

Brown, N., Rip, A., \& Van Lente, H. (2003). Expectations in \& about science and technology. In A Background Paper for the 'Expectations' Workshop of 13-14 June (1-14).

EU Council. (2005). Prüm Convention. Brussels.

EU Council. (2008a). Council Decision 2008/615/JHA of 23 June 2008 on the stepping up of cross-border cooperation, particularly in combating terrorism and crossborder crime. Official Journal of the European Union. Brussels.

EU Council. (2008b). Council Decision 2008/616/JHA of 23 June 2008 on the implementation of Decision 2008/615/JHA on the stepping up of cross-border cooperation, particularly in combating terrorism and cross-border crime. Official Journal of the European Union. Brussels.

EU Council. (2021). Implementation of the provisions on information exchange of the "Prüm Decisions". Official Journal of the European Union. Brussels.

Guild, E. \& Geyer, F. (Eds). (2008). Security Versus Justice? Police and Judicial Cooperation in the European Union. Farnham: Ashgate. https://doi.org/10.4324/ 9781315608136.

Hielscher, S. \& Kivimaa, P. (2018). Governance through expectations: examining the long-term policy relevance of smart meters in the United Kingdom. Futures, 109, 153-169. https://doi.org/10.1016/j.futures.2018.06.016. 
Hufnagel, S. \& McCartney, C. (Eds). (2017). Trust in International Police and Justice Cooperation. Oxford: Hart Publishing. http://dx.doi.org/10.5040/9781782257868.

Innes, M., Fielding, N., \& Cope, N. (2005). "The appliance of science?": the theory and practice of crime intelligence analysis. British Journal of Criminology, 45(1), 3957. https://doi.org/10.1093/bjc/azh053.

Jasanoff, S. \& Kim, S.-H. (Eds). (2015). Dreamscapes of Modernity: Sociotechnical Imaginaries and the Fabrication of Power. Chicago and London: University of California Press. https://doi.org/10.7208/chicago/9780226276663.001.0001.

Jasanoff, S. \& Kim, S.H. (2009). Containing the atom: Sociotechnical imaginaries and nuclear power in the United States and South Korea. Minerva, 47(2), 119-146. https:// doi.org/10.1007/s11024-009-9124-4.

Konrad, K. (2006). The social dynamics of expectations: the interaction of collective and actor-specific expectations on electronic commerce and interactive television. Technology Analysis \& Strategic Management, 18(3-4),429-444. https://doi.org/10. 1080/09537320600777192.

Luif, P. (2007, 17-19 May). The Treaty of Prüm: A Replay of Schengen? [Conference presentation]. European Union Studies Association, Tenth Biennial International Conference, Montreal.

Lynch, M., Cole, S.A., McNallly, R., \& Jordan, K. (2008). Truth Machine: The Contentious History of DNA Fingerprinting. Chicago: University of Chicago Press. http s://doi.org/10.1017/CBO9781107415324.004.

Machado, H. \& Granja, R. (2018). Ethics in transnational forensic DNA data exchange in the EU: constructing boundaries and managing controversies. Science as Culture, 27(2), 242-264. https://doi.org/10.1080/09505431.2018.1425385.

Machado, H. \& Granja, R. (2019). Police epistemic culture and boundary work with judicial authorities and forensic scientists: The case of transnational DNA data exchange in the EU. New Genetics and Society, 38(3), 289-307. https://doi.org/10. 1080/14636778.2019.1609350.

Machado, H., Granja, R., \& Amelung, N. (2020). Constructing suspicion through forensic DNA databases in the EU. The views of the Prüm professionals. The British Journal of Criminology, 60(1), 141-159. https://doi.org/10.1093/bjc/azz057.

McCartney, C. (2014). Forensic data exchange: ensuring integrity. Australian Journal of Forensic Sciences, 47(1), 36-48. https://doi.org/10.1080/00450618.2014.906654.

McCartney, C., Wilson, T., \& Williams, R. (2011). Transnational exchange of forensic DNA: viability, legitimacy, and acceptability. European Journal on Criminal Policy and Research, 17(4), 305-322. https://doi.org/10.1007/s10610-011-9154-y.

Pieri, E. (2009). Sociology of expectation and the e-social science agenda. Information, Communication \& Society, 12(7), 1103-1118. https://doi.org/10.1080/13691180902998647.

Prainsack, B. \& Toom, V. (2010). The Prüm regime. Situated dis/empowerment in transnational DNA profile exchange. British Journal of Criminology, 50(6), 11171135. https://doi.org/10.1093/bjc/azq055.

Prainsack, B. \& Toom, V. (2013). Performing the Union: the Prüm decision and the european dream. Studies in History and Philosophy of Biological and Biomedical Sciences, 44(1), 71-79. https://doi.org/10.1016/j.shpsc.2012.09.009.

Quinlan, A. (2020). The rape kit's promise: techno-optimism in the fight against the backlog. Science as Culture, 1-25. https://doi.org/10.1080/09505431.2020.1846696.

Sallavaci, O. (2017). Strengthening cross-border law enforcement cooperation in the EU: the Prüm network of data exchange. European Journal on Criminal Policy and Research, 24(3), 219-235. https://doi.org/10.1007/s10610-017-9355-0. 


\section{Genetic Surveillance and Crime Control}

Santos, F. (2017). The Transnational Exchange of DNA Data: Global Standards and Local Practices. In K. Jakobs \& K. Blind (Eds), Proceedings of The 22nd EURAS Annual Standardisation Conference. Digitalisation: Challenge and Opportunity for Standardisation (305-322). Aachen: Verlag Mainz.

Santos, F. \& Machado, H. (2017). Patterns of exchange of forensic DNA data in the European Union through the Prüm system. Science \& Justice, 57(4), 307-313. https:// doi.org/10.1016/j.scijus.2017.04.001.

Sulca, D. (2017). Intelligence-Led Use of International Forensic Exchange Channels. In S. Hufnagel \& C. McCartney (Eds), Trust in International Police and Justice Cooperation (241-254). Oxford and Portland, OR: Bloomsbury. http://dx.doi.org/10. 5040/9781782257868.ch-012.

Taverne, M. \& Broeders, T. (2015). The Light's at the End of the Funnel! Evaluating the Effectiveness of the Transnational Exchange of DNA Profiles Between the Netherlands and Other Prüm Countries. Zutphen: Paris Legal Publishers.

Toom, V. (2018). Cross-Border Exchange and Comparison of Forensic DNA Data in the Context of the Prüm Decision. Civil Liberties, Justice and Home Affairs. Parliament's Committee on Civil Liberties, Justice and Home Affairs and Policy Department for Citizen's Rights and Constitutional Affairs. European Parliament, Brussels.

Toom, V., Granja, R., \& Ludwig, A. (2019). The Prüm Decisions as an aspirational regime: reviewing a decade of cross-border exchange and comparison of forensic DNA data. Forensic Science International: Genetics, 41(April), 50-57. https://doi. org/10.1016/j.fsigen.2019.03.023.

Töpfer, E. (2011). 'Network with errors': Europe's emerging web of DNA databases. StateWatch Analysis, 21(1), 1-5.

Tutton, R. (2020). Sociotechnical imaginaries and techno-optimism: examining outer space utopias of Silicon Valley. Science as Culture, 1-24. https://doi.org/10.1080/ 09505431.2020.1841151.

Van der Beek, K. (2011). Forensic DNA Profiles Crossing Borders in Europe (Implementation of the Treaty of Prüm). In Profiles in DNA, 1-14.

Wienroth, M. (2020). Socio-technical disagreements as ethical fora: Parabon NanoLab's forensic DNA Snapshot ${ }^{\mathrm{TM}}$ service at the intersection of discourses around robust science, technology validation, and commerce. BioSocieties, 15(1), 28-45. https://doi.org/10.1057/s41292-018-0138-8.

Williams, R. \& Johnson, P. (2004). Circuits of surveillance. Surveillance \& Society, 2 (1), 1-14. https://doi.org/10.1901/jaba.2004.2-1.

Wilson, T. (2016). Criminal justice and global public goods: the Prüm forensic biometric cooperation model. The Journal of Criminal Law, 80(5), 303-326. https://doi. org/10.1177/0022018316668450. 


\section{Genetic Surveillance in Post- Communist European Countries}

\section{Introduction}

There is a scarcity of knowledge about the current situation regarding genetic surveillance for the governance of crime in countries that are part of the socalled Central and Eastern Europe (CEE), usually intended to designate those states formerly comprising the Eastern European bloc. During the Stalinist period, the communist states and the Soviet Union were totalitarian societies. In the post-Stalin period, many of the communist states in Europe began to develop towards a more pragmatic, although not necessarily, less repressive authoritarianism. This chapter explores the views about genetic surveillance constructed by forensic geneticists working in laboratories based in CEE countries. The analysis is based on testimonies collected from interviews carried out between 2016 and 2018 in CEE countries, namely: Bulgaria, Czech Republic, Estonia, Hungary, Lithuania, Latvia, Poland, and Romania. The research questions guiding this chapter are the following: what are the expectations of forensic geneticists towards genetic surveillance in CEE countries? In which ways the past experience of repressive and violent surveillance (not necessarily with sophisticated technologies) generate implications for understanding the present and the future of forensic genetic technologies in these particular social contexts?

This group of countries has undergone diverse transition processes, resulting in a wide range of regimes, from authoritarianism and totalitarism to nearly consolidated democracies, thereby making generalizations rather difficult. Joseph Rothschild and Nancy M. Wingfield (2007) discussed the contrast between the wealthiest states, such as the Czech Republic, Hungary, Poland, and Slovenia, as opposed to countries like Bulgaria, Romania, and Slovakia, whose weaker economies made it harder to endure such political, social, and economic transitions. Moreover, transitions were also marked by each country's national history, namely their communist legacies. While most of these countries are known for a past marked by extensive state surveillance, state paternalism (Schwartz \& Bardi, 1997), and economic black markets (Los, 2003), the implementation of institutional reforms have varied widely in

DOI: $10.4324 / 9780429261435-4$ 


\section{2}

Genetic Surveillance and Crime Control

speed and depth (Rothschild \& Wingfield, 2007). In Czechoslovakia, Hungary, and Poland, a private sector with some autonomy existed in the 1970s and 1980s, despite periods of severe repression; in Bulgaria and Romania, however, totalitarianism or severe authoritarianism persisted until 1989 or 1990 (Svenonius \& Björklund, 2014).

Poland and Hungary made the transition from authoritarianism to democratic states in 1989, although the two countries have been frequently under the scrutiny of the European Union (EU) because of doubts regarding a lack of compliance with the EU democratic standards (Bunce, McFaul, \& StonerWeiss, 2010). The recent democratic backlashes in Hungary and Poland show that the post-communist democracies could be more fragile than was initially assumed because of the persistence of legacy and political structures (Svenonius \& Tarasova, 2021). Matters of concern are related to high-level corruption, national justice systems, media freedom, telecommunications data retention without judicial control, as well as anti-immigration attitudes in the case of Hungary (Stone, 2018). Lithuania, Latvia, and Estonia were Soviet Republics from 1940 onwards, gaining independence after the disintegration of the USSR in 1991. Czechoslovakia gained independence after the disintegration of the Soviet Union, leading to its division on 1 January 1993 and resulting in the foundation of two states (the Czech Republic and Slovakia). While the 1989 revolutions, with the exception of Romania, can be considered peaceful in most nations of the Eastern Bloc (Sztompka, 1996), they also meant the collapse of former social-control structures and the need to initiate processes of institutionalization. Some authors suggest that the collective imagery underlying the democratic transition was inspired by a "return to Europe" (Lauristin, 2007; Vaduchova, 2015), and this carried with it significant social, political, economic, and legal transformations. On 1 May 2004 the EU accepted the Czech Republic, Estonia, Hungary, Latvia, Lithuania, Poland, Slovakia, and Slovenia as new members. On 1 January 2007 Bulgaria and Romania also joined the EU. The admission of these countries into the EU made their integration into the cooperative police and legal crime-fighting networks mandatory. In sum, the CEE countries present varied historical, political, economic, and social situations. Nonetheless, that fact alone does not invalidate analyses of common aspects across the various countries, namely their pasts of extreme surveillance societies and its implications on expectations towards genetic surveillance for the governance of crime. Highly secretive and extensive information systems aimed at control and subjugation of entire populations were a defining characteristic of this group of countries. Surveillance practices such as infiltration, mail interception, and wiretapping were integral aspects of everyday life (Svenonius \& Björklund, 2014). Although the terms "post-communist" and "post-socialist" and are mostly interchangeable, in this chapter we use the term "post-communism" to focus more on the institutional and formal changes, whereas "post-socialism" is generally used to refer to issues concerning with culture, subjectivities, and everyday life. We also follow the proposal by Ola Svenonius and Ekaterina 
Tarasova (2021) to use the term "post-communist" because it is most commonly used in literature.

This chapter aims to contributing to studies of surveillance in post-totalitarian societies which have experienced a transition to democracy. The evocation of a socialist past can be used to (re)configure and give voice to social anxieties, enabling a sense of community and nationality (Halbwachs, 1980; Spülbeck, 2000). However, we also argue that such historical and socio-cultural aspects deserve specific investigations which should not only be framed by the "legacies" argument (Boersma et al., 2014, p. 3). Considering how these countries experienced endemic authoritarian surveillance practices for decades, the point of departure for the analysis presented in this chapter is the assumption that the widespread abuse of surveillance information, the distrust of public institutions, and a culture of corruption present in most CEE countries (Svenonius \& Björklund, 2018) might play a crucial role in understanding the expectations placed upon the implementation of forensic genetic technologies in the activities of the criminal justice systems.

This chapter main contribution is, therefore, to provide empirical analysis about views on genetic surveillance from forensic geneticists living and working in post-totalitarian societies which have experienced a transition to democracy. We are actively engaged within critical reflexivity to avoid falling into the temptation to study the presence of forensic genetics technologies in the criminal justice system in Eastern European countries as from the (imperfect) realization of universal theories and laws of development generated from "modern societies" of the global North (Carrington, Hogg \& Sozzo, 2016, p. 3). This approach is necessarily uncritical and reductionist: it not only essentializes the knowledge and experiences of "more developed" societies, as if they were universal, but is also holds the risk of romanticizing knowledge production in the global South (McLean, Worden, \& Kim, 2013, pp. 121-125).

This chapter is divided into four parts. The first section provides an overview in regard to trends of criminality in the historical phase of transition from totalitarianism to democracy. It also presents arguments related to the existence of a special kind of "surveillance vulnerability" in CEE countries mostly linked to the fact that surveillance has permeated the relationship between the state and the citizens well beyond the end of totalitarianism (Richterova, 2018; Svenonius \& Björklund, 2018).

The second section portrays the expansion of genetic surveillance through the increasing use of forensic genetic databases. More specifically, we describe the general legislation trends, the development of forensic genetic databases, as well as the style of organization, operation, and scale of these databases. There seems to be a trend towards expanding the size and reach of the genetic databases controlled by the police, thereby contributing to a phenomenon we conceptualize as a genetic surveillance expansion.

In the third part of this chapter, we explore the discourses provided by the interviewees on how they perceive and attribute meaning to the uses of 
genetic technologies and genetic databases for criminal investigation purposes. We will attempt to show why the visions of forensic geneticists reproduce an imagery shaped by a socialist legacy, with all the implications entailed by this political regime in terms of the relationship between the state and its citizens. The perception of the inherent risks of collecting citizens' genetic data (and other kinds of data) as a tool of social control and law enforcement can be transferred into the complex and ambivalent relationship of public (dis)trust in the justice system and state institutions.

Finally, the fourth section looks into the particular case of CEE citizens within the Prüm system. More particularly, by analyzing how Eastern Europeans are collectively construed as a suspect community. Such a construction is supported by perceptions on the direction of migratory flows of people travelling from the East to the West, hence underlining the role of CEE countries in the management of their own "risky" populations (Machado, Granja \& Amelung, 2020).

The case of forensic genetics in post-communist countries in Europe therefore integrates at least three elements that will be explored in the next pages. First, a concrete dimension, materialized in practices of expansion in the use of genetic technologies to collect data from citizens. Second, a political dimension, which reverts to relationships of distrust and trauma experienced under totalitarian regimes of the past. Third, a discursive and symbolic dimension, present in discourses that criminalize individuals and populations from post-communist countries in Europe.

\section{Historical legacy and criminality}

The concept of legacy plays a vital role in studies about collective memories in post-communist societies, implying the assumption that certain cultural mind-sets have prevailed since the time of the communist regimes and that people's collective memories of the past shape how they deal with the present (Wittenberg, 2015). On the one hand, debates have revolved around the coming to terms with a socialist past. On the other hand, and intimately connected to that, there are discussions about the pervasive influence of socialism upon interpretations of the current situation across various spheres of activity (economic, religious, cultural, etc.). In the wake of Peter J. Verovšek's proposal for a methodology to study collective memories (2016), this chapter pursues a dialogical approach that interprets the politics of memory as a communicative paradigm, involving "not only the substantive content of ideas but also the interactive processes by which ideas are conveyed" (Verovšek, 2016, p. 7).

In this context, the concept of legacy associated with varying interpretations of a socialist past will prove invaluable to analyze the discourses of local forensic experts concerning the role of genetic technologies in the fight against criminality. However, the concept of legacy alone does not account for other values and subjective elements, namely the feelings of (in)security and (dis) 
trust vis-à-vis political power and legal or governmental institutions. Some authors refer the importance of "existential insecurity" to understand social representations linked to justice and crime in CEE countries. Despite the vast differences between types of socialism in the region, the existential insecurity that characterized the period after the fall of the Iron Curtain in post-communist societies has been an essential factor behind concepts like "cultural trauma" and the "post-communist condition" (Holmes, 1997; Sztompka, 2000). As observed by Marina Caparini and Otwin Marenin, in their essay about crime, insecurity and police reform in post-socialist CEE, such countries faced a wide array of challenges:

With the change in regime in 1989, CEE states faced a triple challenge: overcoming the communist legacies in their criminal justice systems; reforming the police to reflect principles of democratic policing, including international standards in human rights; and contending with the growth in crime and public fear of crime.

(Caparini \& Marenin, 2005, p. 4)

There seems to be a generalized consensus that the repressive surveillance and political control were detrimental to social trust (Horne, 2014; Hosking, 2013), and that the lack of civic engagement was prominent (Hooghe \& Quintelier, 2014). One other element that resonates with the past is the apparent widespread acceptance of state surveillance practices over citizens, which Ola Svenonius and Fredrika Björklund refer to as a "surveillance vulnerability" (Svenonius \& Björklund, 2018) and that a "surveillance drive" persists from the past regime leading to the risk of re-institutionalized authoritarian regime (Svenonius \& Tarasova, 2021). In the perspective of such works, the notion of surveillance vulnerability and the idea of continuity of surveillance from the communist era implies that some societies could be more receptive to harsh, intrusive actions by police forces than others. This vulnerability and the notion of historical regularities are more prone to occur wherever communities believe that criminal threats are significant and imminent and wherever they have past experiences of being permanently subjected to rigorous surveillance by the police and the government. Consequently, surveillance vulnerability and the materiality of communist legacies can vary considerably according to each national situation.

Dismantling of the Soviet Union entailed significant political, economic, and social changes. The emergence and development of a market economy, the expansion of private services, the opening of borders and the admission of foreign capital led to social transformations which, according to Beata Gruszczyńska (2004), might have created more opportunities for criminal activities. According to this author, the weakening of formal and informal control, the disarray in which several social structures found themselves, the police and the courts' lack of experience to deal with increasing criminal activity, and the rapidly encroaching poverty, all contributed towards a 
significant increase in criminality during the 1990s (Gruszczyńska, 2004). This observation is corroborated by other studies (Šelih \& Završnik, 2012) highlighting the marked increase of thefts, robberies and assaults during the last decade of the past century, as well as the expansion of organized crime (Hignett, 2004, 2010), and drug-related offences.

The CEE countries experienced both domestic and transnational crime. They formed an essential link in the criminal corridor from the east to the west, from the south to the north (and the reverse) in car thefts and drug crimes. Initially, CEE were destination countries and - over time they became transit countries.

(Gruszczyńska, 2004, p. 125)

Nonetheless, it is important to note that this alleged increase in criminality cannot be accurately gauged or calculated. It is impossible to establish a reliable comparison with the criminality statistics from previous decades, since many communist regimes tended not to divulge or register such statistics. Similarly, it is difficult to compare criminality trends across European countries, since the collection and treatment methods for statistical data differ from one country to the other. Generally speaking, criminality in these countries follows similar trends to those observed in Western European countries, albeit with a delay, so that the convergence only took place in the second half of the 1990s. According to Gruszczyńska:

In some countries and for some types of crime, the trends in CEE are similar to those in the WE countries. The dynamics of assaults in the Czech Republic, Hungary and Poland are similar to those observed in Western Europe. This also holds for the dynamics of robbery and theft in the Czech Republic and Hungary (and also partly in Poland). The drug offences should be compared in a different perspective. In CEE countries a significant increase of such crime was observed in the second half of the 1990s.

(Gruszczyńska, 2004, p. 134)

Variation in crime patterns and judicial trends among CEE countries is therefore perceptible. For example, in Poland, the guiding principles adopted following the regime change of 1989 led to the implementation of liberalization policies in the justice system, only later followed by the public's fear of crime. In this country, around the mid-1990s, sentencing became more severe, imprisonment rates increased steeply, and Polish penal policies swerved away from the path towards liberalization. In other countries, namely in the Balkans, the emergence of state-organized syndicates engaged in smuggling all kinds of goods and people undermined much of the impetus for reform, leading to an increase of public demand for a crackdown on crime (Caparini \& Marenin, 2005, p. 18). Consequently, there was an implementation of 
policies that sought to tighten control over criminality and perpetuate mass surveillance systems, which in turn has since perpetuated more repressive policies and the reinforcement of police authority.

\section{Expansion of genetic surveillance}

All the CEE countries included in the analysis proposed in this chapter have a national forensic genetic database for criminal investigation purposes. In this section, we will detail their main features in terms of dimension, organization and regulation. The size of the national forensic DNA databases varies significantly across this group of CEE countries. In this respect, Estonia stands out. Considering proportional population coverage, taking as reference the statistics for the resident population in the country - a factor normally used to evaluate the "size" for this type of database - Estonia's database is one of the largest in Europe. It is second only to the databases in the United Kingdom, which include 8.8 per cent of the population, and France, including 5 per cent of the population.

As we can see in Table 4.1, the CEE countries with the largest databases are Estonia, Latvia, and Lithuania. It is worth noting that, in this group of countries, databases are larger than those in other western European countries, such Germany and the Netherlands. This seems especially relevant considering that Germany and the Netherlands have distinguished themselves in the landscape of European security for their proactivity when it comes to developing biometric technological infrastructures and data exchange for crime fighting purposes, namely through the Prüm System (Amelung, Granja \& Machado, 2020).

The Czech Republic, Hungary, Slovakia, and Slovenia possess forensic DNA databases of similar size to other European countries, such as the

Table 4.1 Characteristics of forensic DNA databases in CEE countries

\begin{tabular}{llll}
\hline Country & Date of creation & Number of profiles & $\begin{array}{l}\text { \% of population } \\
\text { included }\end{array}$ \\
\hline Czech Republic & 2001 & 186,111 & 1.8 \\
Bulgaria & 2000 & 17,618 & 0.2 \\
Estonia & 2004 & 49,421 & 3.8 \\
Hungary & 2004 & 148,324 & 1.5 \\
Latvia & 2005 & 53,546 & 2.6 \\
Lithuania & 2002 & 87,310 & 2.6 \\
Poland & 2007 & 46,579 & 0.1 \\
Romania & 2008 & 32,149 & 0.2 \\
Slovakia & 2004 & 55,559 & 1 \\
Slovenia & 1998 & 31,533 & 1.6 \\
\hline
\end{tabular}

Source: Reed \& Syndercombe-Court (2016). 
Netherlands (1.4 per cent) and Germany (with 1 per cent of the population). Countries such as Poland, Bulgaria, and Romania possess small genetic databases, closely mirroring the situation in other European countries, as for example Spain (with 0.6 per cent of the population), Luxembourg (0.4 per cent), and Belgium ( 0.35 per cent).

In terms of legal guidelines, the general trend in countries with more extensive databases is to follow an expansive strategy, while countries with smaller databases follow more restrictive legal trends (Santos, Machado, \& Silva, 2013). In other words, national legislations responsible for defining the criteria for the collection, creation, and removal of DNA profiles from the forensic genetics database will have a bearing on the size of the respective criminal DNA database.

Countries with expansive legal trends present lower thresholds for inclusion and lengthier retention periods for profiles, which could allow for faster expansion in the number of profiles in the DNA database. According to Filipe Santos and his colleagues (Santos et al., 2013), the CEE countries with more expansive guidelines are Estonia, Latvia, Lithuania, and Slovakia. Generally, the inclusion criteria in most "expansive countries" allow the submission of sample collection from individuals suspected of any crime and, consequently, inclusion of their own DNA profiles in the forensic database. For example, in Estonia, the police may take a DNA sample from all suspects and convicted offenders. It is mandatory for any person arrested or convicted for a crimerelated activity to provide a DNA sample. A sample may be taken coercively if consent is withheld. Estonian legislation allows all DNA profiles to be entered automatically in the database for speculative searches. No restrictions are imposed on the type of offence warranting a speculative search, and no prior court authorization is required (Reed \& Syndercombe-Court,2016).

In these "expansionist countries," the database tends to be controlled and managed by police forces, without the independent supervision from any other organization or institution over the activities involving the use of this kind of databases. For example, the Latvian database is supervised and managed by the Forensic Service Department of the Latvian State Police, implying there is not an autonomous, external entity monitoring and supervising that will be liable to rouse ethical issues or conflicts linked to the protection of personal data and other sensitive information.

In the group of countries where legislation is considered to have a restrictive function, typically the condition imposed for including profiles in databases is either that an individual is suspected or convicted of a crime that could lead to a prison sentence, or that the crimes committed by an individual subjected to the collection of a biological sample are considered serious (Santos et al., 2013). This type of legal framework established a predominant trend of genetic databases with fewer genetic profiles than those in more "expansive" countries. This results primarily from two interrelated factors: stricter criteria for the creation of genetic profiles in the databases and/or more limited retention and storing periods for these kinds of data. 
Within this CEE group, Bulgaria, Poland, and Romania might be considered restrictive countries. In Poland, for example, DNA samples and profiles of persons who have been acquitted, whose cases have been dropped, or have been conditionally discharged, may have their samples and profiles removed from the database. In Romania, the legal power to take DNA samples from suspects is subject to the written permission from the investigating prosecutor or a court order (Reed \& Syndercombe-Court, 2016).

Countries such as Hungary and the Czech Republic show a trend towards expansion in their databases (see Table 4.1), although the legal framework in both countries might be considered at the same time restrictive and expansionist, as it merges characteristics from both groups. In Hungary, for instance, DNA profiles from convicted offenders may be retained for up to 20 years from the date of sentencing. But the uploading of the DNA profiles in the criminal database by police must be overseen and authorized by the Ministry of Justice and Law Enforcement. In the Czech Republic, samples and profiles alike can be preserved for as long as deemed necessary for crime prevention and detection or the conduction of criminal investigations. However, preservation is subject to review every three years to determine whether retention of the samples and profiles is still warranted (Reed \& SyndercombeCourt, 2016).

Nonetheless, even considering countries with a relatively small database of DNA profiles, this does not preclude the existence of a trend towards expanding genetic surveillance. For example, interviewees across all countries mentioned the use and/or interest in using genetic technologies such as mass screenings, familial searching and forensic DNA phenotyping. Such technologies, which are aimed at generating intelligence for criminal investigations, move the locus from individualization - that is, identification of specific individuals - towards collectivization (Machado \& Granja, 2020, p. 86). Such a sweeping use of DNA technologies thereby constitutes a clear example of attempts to expand genetic surveillance beyond DNA profiling and DNA databasing.

Another important aspect of genetic surveillance expansion of is linked to the social representations about the future of DNA technologies and the expectations associated with its governance. Interviewees in this study recurrently upheld the view that it would be positive to create a universal database; that is, containing the genetic data of the entire resident population in a specific country. Curiously, a specific idea was asserted on this point regarding the integration of CEE countries. The idea of European integration reveals a willingness to come closer to European values, while at the same time denoting a criticism towards Eastern European politicians' subjection to the decisions stemming from the European Commission. The following account by a participant in the study, lamenting how it is impossible to create a universal database in his country, is illustrative of such a view. This interviewee believes that politicians are afraid Europe would reject such projects based on issues of citizen privacy protection. 
Politicians would never agree with the creation of a universal DNA database. We can dream about it, but they'd never agree. Why? I think they are afraid. They are too eager to please Europe. The politicians would never agree because national laws are all about data protection and are all strictly reviewed by a data protection agency. And our data protection agency gets its directions from the EU and follows them.

(Interview B01)

This interview quotation illustrates two interrelated aspects of crucial importance for understanding the views and expectations towards genetic surveillance in post-communist European countries: first, that an understanding of the past and its legacies could shed light on contemporary perceptions of surveillance, resistance and/or resilience to surveillance. This aspect will be analyzed in detail in the following sections of this chapter. A second element relies on how modes of imposing global ways of using and implementing genetic technologies for governance of crime are articulated in a specific way in different contexts - and thus are continually "territorialized" and "de-territorialized" - defining individual, collective values and discursive forms (Ong \& Collier, 2005).

Eastern European countries' adherence to standards imposed by transnational institutions such as the European Commission or, more abstractly and generally, by organizations promoting globalization (whether in science and technology, or in industries and commercial circuits associated with security and police operations) illustrates the ways in which normative governmentality (Dunn, 2005), emanating from different political and economic sources, claims to transform technical, scientific, and social structures, and to be applicable across geographies and diverse histories and institutions. Examining normative governmentality in the context of CEE countries opens up a window to criticize claims that the EU and its standardizers make about harmonization and inclusivity. In CEE countries, owing to the institutional legacy of communism, the imposition of rules and standardization and harmonization has the effect of causing some social actors and institutions to try to imitate these models, and can create strong incentives for resistance to change. This last type of reaction is often understood as the type of response expected from populations that have been under the domain of communism and that instigates people to distrust or avoid any type of new power or social and disciplinary control (Dunn, 2005, p. 175).

\section{Views about police forces and the influence of legacy}

As we noted in the introduction to this chapter, while authoritarian communist regimes were in power, the state conditioned all social life. The legacy of socialist societies, therefore, undeniably shapes the present and conditions the future across many spheres of social life - from scientific production to the criminal justice system. Interviewees' accounts reflect signs of a collective 
trauma that gives meaning to actions and social phenomenon as seen through a prism that projects onto the conditions faced in the present. It's a "transmutable past" (Pavlovich, 2018) by which people frame, contextualize, and give meaning to the events and actions. In the words of William V. Pavlovich, by narrating the experiences of their past, "people engage in meaning-making practices whereby individual experiences are linked to larger social, political and economic processes, especially when that past was traumatic and affects present identities" (Pavlovich, 2018, p. 257).

This "transmutable past" (Pavlovich, 2018) transpires in how interviewees give meaning to forensic genetic technologies in post-communist societies. A particularly relevant example of this mindset is provided by a forensic expert, who alludes to the difficulty in explaining how the authoritarian past continues to have consequences on the daily lives of societies in the present. Society was completely controlled and monitored by the state system, from citizens' daily lives to how science was produced. State regulation, bureaucracy, and surveillance were, therefore, a major part of social life (Svenonius \& Björklund, 2014). In the participant's words:

We were part of the socialist block of countries in Europe. So, we were under the strong influence of the Soviet Union and we adopted many regulations and other things from the Soviet Union. Everything was regulated in the [country], every aspect of life, of... How to say it? Science and other things were under the influence of the socialist thinking and the Soviet Union (...) life here was very influenced by this (...). We were not allowed to travel to Western countries, for example, and we did not have reliable and updated information from the world outside, as it was filtered by the soviet and socialist control or surveillance.

(Interview L01)

According to this forensic geneticist's perspective, such a legacy has considerable influence over current relationships between citizens and the police, which are heavily marked by distrust. When referring to traumatic memories brought by police forces, this interviewee highlights the tradition and notorious cultural legacy found in post-communist societies regarding the collection of citizen information and data. In the participant's perspective, this massive surveillance was carried out by the police, entrusted with protecting the interests of the state and keeping citizens under absolute control.

In [this particular country] there is a very bad relationship between citizens and the police (...) I think it has historic reasons. Since it used to be a socialist country, it was a totalitarian regime, and back then the police was a tool of government and hence of the leading communist party, so it had a very bad reputation. It watched and persecuted people, so they had a very bad relationship with the police. And even though the police has changed and is now different and more modern, this feeling is still 
present. The relationship of suspicion with the police is still clear. So people view the DNA database mostly as a danger to their rights and freedoms.

(Interview L01)

Such a legacy of distrust ultimately influences how citizens perceive the implementation of a police-managed forensic database containing DNA profiles. The following testimony of a forensic geneticist is an example of this view. According to this account, there is a lack of transparency in how databases of DNA profiles are used by the police, given that citizens cannot know how the information is used and there is no entity to ensure independent supervision of police activities involving the use of genetic technologies in criminal investigations. In his own words:

There is a problem with the transparency of criminal DNA databases. Most of them are managed by the police, and police services in most countries are not transparent (...) I can say this regarding our DNA database. Currently there is no control over our national DNA database, there is no independent committee checking what is happening in our national DNA database.

(Interview J02)

The same interviewee points out the fear of a future reversion to a dictatorial regime, a particularly troubling prospect considering how it would place especially sensitive information, such as the citizens' genetic data, in the hands of an authoritarian power:

That's why I have fears for the future. Now we have a democratic regime... it is the same in European countries, and as far as we don't have dictatorial regimes, things will be under control, let's say. But you never know what will happen in the future (...) Political intrusion is the main concern. Not really the genetic information itself, but the political intrusion in this huge information system... And that scenario is... well, let's just say it's not such a distant one for us.

(Interview J02)

Some of the interviewees mention that the consolidation of democratic regimes could lead citizens to place more trust on authorities and police forces. One of the forensic geneticists interviewed, at the time working in a forensic genetics laboratory under the guidance of the Ministry of the Interior, noted how the police was becoming increasingly modern and set to conquer the trust of citizens. Nonetheless, memories of past abusive police practices are still alive in the collective memory.

People do not trust the police enough, right now. I think that, due to historical reasons, we are still in the process of gaining enough of that 
trust (...) Generally speaking, I think that trust in the authorities is something that we're on a good road to achieving. I would really like to see that, and I think it's just a matter of time; as enough time passes, generations will change.

(Interview K01)

The interviewee believes that in order to consolidate such public trust, there is a need for public engagement with genetic technologies, as well as the development of regulations ensuring an effective protection of citizens' sensitive data. In his view, this is an issue in which being aligned with the public's interest is of paramount importance. In his own words:

Whether or not the risks of forensic genetic technologies can be averted through well designed regulations for the usage of data... although it's not just a matter of risk, it's also a matter of the public's reassurance. I think that where this kind of deeply personal things are concerned, the opinion of the public should be the main priority (...) I think the main problem would be the issue of trust in authorities. If the community trusts the authorities ... the main obstacles would be the fear of releasing information in a way that could somehow affect the person's life negatively.

(Interview K01)

A key aspect of post-communist societies' history and culture to take into consideration, if we are to evaluate the place of forensic genetic technologies in the criminal justice system, is linked to how society views the role and activity of police forces. Memories of the past and perceptions about the historic legacy of police continue to influence current police structures and organizations, as well as the criminal justice system (Caparini \& Marenin, 2005; Mesko et al., 2013). Although the deep social and political changes that took place in CEE countries have inarguably altered the structure and role of the police, police forces continue to be associated, at least from the point of view of common citizens in postcommunist countries, with authoritarian political regimes and oppressive population surveillance, including the mass collection of citizen information (Mawby, 2000; Svenonius \& Björklund, 2018).

\section{The Prüm system and criminalization of CEE citizens}

All the countries mentioned in this chapter participate in a transnational system for exchanging DNA data among EU Member States, known as the Prüm system (described in detail in Chapter 3). The European Commission has made the implementation of the Prüm system a mandatory instrument in the fight against cross-borders criminality and terrorism. Through the Prüm system, EU Member States were obligated to create structures for the permanent, automated, and reciprocal access to DNA and other types of data held in national databases. According to Paul Luif (2007), the initiative to 
create the Prüm system was deemed necessary because of "transnational crime, which had increased after the removing of the Iron curtain at the end of the Cold War and which had been made easier by the ceasing of border controls between the participants of the Schengen area" (Luif, 2007, p. 6) ${ }^{1}$.

Academic studies on the transnational exchange of DNA data through the Prüm system have mapped the geographical patterns of cross-border crimes solved by the exchange of DNA data among different EU Member States (Bernasco, Lammers, \& Van der Beek, 2016; Taverne \& Broeders, 2015, 2017). One study suggested a territorial divide between Central and Western European countries on the one side and CEE countries on the other: based on an analysis of the official statistical dataset of the Prüm system, this research revealed a trend among Central Western European countries to accumulate the majority of DNA profiles of individuals originating from CEE countries (Santos \& Machado, 2017). In other words, the study showed how the geographical patterns of DNA flows between the EU Member States involved in the Prüm system seemed to confirm previous research on patterns of criminal mobility affecting Central West European countries, mostly associated with a volume of crime that usually involved individuals originating from CEE countries (Bernasco et al., 2016; Siegel, 2014; Van Daele, 2008).

The Western views on the East as an alien and underdeveloped region (Lauristin, 2007) suggest a cautious distrust towards some EU members. The admission of Bulgaria and Romania to the EU in 2007, for example, raised a wave of "moral panic" (Cohen, 1985) in the British media that vented fears of UK flooding by migrants from these countries, expressed in headlines which cast citizens from these countries as "undesirables" or "gangsters" (Light \& Young, 2009; Mawby \& Gisby, 2009) and portrayed stereotypical sensationalist images associating immigrants with criminality. This continues to be a dominant feature across political, media, and general public discourses, whereby people from CEE countries are depicted as crime-prone (Broeders, 2007; Guild \& Geyer, 2008; Hufnagel \& McCartney, 2017; Lyon, 2004; Taverne \& Broeders, 2015, 2017). By the same token, the inclusion of CEE countries also roused distinctions and hierarchies between the East and the West within Prüm, contrasting the directionality of scientific innovation (from the West to the East) versus transnational criminal threats (in the reverse direction).

The dissemination pattern of "high-tech" innovation, conceived to flow from the West to the East, is aligned with the reinforcement of geopolitics. Besides being evidenced by the fact that Prüm's leading implementation support teams came from Central European countries (Austria, Germany, and the Netherlands) (Santos, 2017), this flow is also reflected in the accounts of practitioners from $\mathrm{CEE}$ countries. As the following quotations show, forensic experts based in CEE countries consider integration in Prüm as an opportunity to foster the national development of forensic science:

We are competitive and try to sit at the same table with other countries. Sometimes it's gratifying, it's an honour, for example - I am talking from 
my point of view - to sit at the same table with countries like Germany or France, knowing that while there may sometimes be political tensions caused by our [national citizens] presence in their countries, at the same time we can cooperate to make a good Europe and to exchange data in order to be a safer place. So, there's mutual benefit in cooperating on this issue.

(Interview J01)

I have heard these discussions. Should we do it, should we not? From our [country's] point of view, we like it, we do it, and we'll take it as far as it goes. (...) I think we have learned a lot and it has helped our development. Because seeing what the others are doing and having to connect with them and follow their lead, inspires us to improve and do things in a new way.

(Interview B01)

This particular framing of the uses made by CEE countries of forensic DNA databases and transnational DNA exchange for purposes of crime control, thereby reproduces a "premise of Europe's internal East that is still behind Europe and still aspiring to become European" (Kuus, 2004, p. 476). Such a framing continues a long history of opinion and bias that can be traced, for instance, to the enlightenment, whose intellectual elites similarly contributed to create an idea of Eastern Europe as distinct and significantly different from Western Europe (Wolff, 1994).

While discourses on the directionality of scientific innovation chart the flow from the West to the East, discourses on criminal threats seem to point in the opposite direction - that is, from East to West. Suspiciousness towards particular populations located in the territories of CEE countries re-enacts a division from the Cold War by which former post-communist countries are considered risky (M'charek, Schramm, \& Skinner, 2014). Technological systems, like the Prüm system, designed for transnational surveillance of criminalized groups, represent forms of "transmitted discrimination" (Reiner, 2010) that resonate with what David Skinner has described as forms of operating systems of "technosecurity" (Skinner, 2018). This social process of constructing suspicion leads to what we have designated elsewhere as the "co-construction" of suspicion (Machado et al., 2020), meaning that the assumptions about Eastern Europe's risky populations are, as noted by Marje Kuus, "actively used by these countries against their particular Easts" (Kuus, 2004, p. 479). This way of co-constructing suspicion is supported by perceptions about the direction of population flows throughout Europe, hence underlining the role of East European countries in the management of their own "risky" populations.

Given the asymmetrical geopolitical distribution of power between East and West, the use of technology coupled with the perceived directionality of criminal threats in the EU could put pressure on CEE countries to internalize the costs of crime (Wilson, 2016, p. 305). This seems to highlight the asymmetrical 
proportion of contributions (databasing known criminal offenders) and the reaping of benefits (obtaining information to solve crimes) between the highly proactive and founding members of Prüm (like Austria, Germany, France, and Spain) and the CEE countries. In other words, geopolitics is equated with the binary relation between technological transference versus transfer of criminality. The co-production of suspicion is not only conveyed by professionals from Western, Central, and Northern Europe (Machado et al., 2020), but also reproduced by respondents from CEE countries who, on the one hand, endorse the assumption that solving crimes depends on their access to bigger DNA databases located in Central-Western Europe. On the other hand, respondents from CEE countries reinforce the idea that national citizens are migrating to other parts of Europe and could commit crimes.

We were mostly looking for areas where you might find larger groups of people [from my country] going to other countries (...) Countries where we know a lot of [our nationals] are travelling to, like Germany, France, Sweden...

(Interview E02)

Regarding the fight against criminality, it's easy to see that (...) when we have a lot of [our nationals] going to other countries to work and actually finding a better place to live, you can have cases, like old cases, that will only be solved by using other countries' databases.

(Interview J01)

Following the same reasoning, to indicate the mobility of criminal groups to richer countries, a forensic geneticist described a criminal case caused by a group of Serbian and Romanian criminals in Switzerland. According to this interviewee, it was only possible to solve this crime thanks to a match in Germany's genetic database, which contained the genetic profiles of some of its members:

I remember a case of a team of robbers causing a lot of damage in Switzerland. They were targeting... very expensive shops with jewellery, watches and things like that. Three were Serbian and one was Romanian. During an armed robbery, one of them was injured and a drop of blood was found on the shop's windows. And they made the profile, then used it to check with the databases in Germany, Austria, and so on. They found the Romanian guy in the German DNA database because several years before he had been involved in car trafficking (...) This démarche was very successful for the Swiss police.

(Interview J02)

Traces of suspicion persist and they are operative in the minds of East Europeans, owing to complex historical and geopolitical intersections between 
power and agency, turning discourses about Eastern Europe fluid and flexible, and therefore durable (Waever, 2000, p. 261). Construing CEE citizens as a suspect community is, therefore, a collective action, through which professionals working with forensic genetics in criminal cases build and reinforce the idea that East European citizens are prone to migrate to other parts of Europe and commit crimes. In this context, the co-construction of suspicion derives from complex geo-political relations, involving certain subjective outlooks that reproduce a continued reliance on "flexible othering" which, albeit operating through multiple demarcations, subtly perpetuates dichotomic notions of East and West, danger, and security (Kuus, 2004).

\section{Conclusion}

Considering the historical, social, and political context of European postcommunist societies, it is vital to reflect upon expectations about forensic genetic technologies, and the views about potential genetic surveillance practices implemented by the state and police forces. This chapter has addressed the expectations, concerns, and fears expressed by interviewees in CEE countries, taking into account the implications of memories aroused by the collective past, namely viewed in the light of the concept of legacy as derived from the historical transition from totalitarian and authoritarian regimes to democratic societies. This chapter thereby aimed to account for the re-emergence of unresolved issues concerning the meaning of the past after the fall of the Iron Curtain and the alleged unification of the European continent under the banner of representative democracy and capitalism, thus once again becoming politically significant (Judt, 2009). The prevalence of keeping returning to a collective past, and invoking national politics through a traumatic history, can be considered a particular form of historical consciousness by which the interviewed forensic geneticists provide meanings to their own actions and roles in society (Beneduce, 2016; Verovšek, 2016).

The discourses of forensic geneticists in post-communist societies expose certain concepts of social risks, public good, and the relations of (dis)trust between the citizens and the state (Granja \& Machado, 2019; Jasanoff \& Kim, 2015). These are key components for addressing the complex and hybrid forms of vulnerability to (genetic) surveillance (Svenonius \& Björklund, 2018). Just as the factors influencing the different perceptions about forensic genetic technologies bear the weight of socio-historical and techno-political backgrounds in a fragmented and complex way, so too the diverse interpretations of the authoritarian communist regimes' legacy pervade discourses of interviewees. The evocation of the political past in former totalitarian communist regimes is especially recurrent, reflecting the subjective effects of the influence exerted by the varying relationships between the state and the citizens, as they transition from authoritarian regimes to democracy.

Such views display recreations of collective memories related with the continuous control of the communist states over the social order, the production 
of science, and the organization of public daily life as a whole. Similarly, the historic legacy of socialism continues to weigh negatively on the public trust in these countries' state institutions (Dimitrova-Grajzl \& Simon, 2010), namely in terms of the criminal justice system, since the state and the police controlled courts and sentencing. Collective memories of the past instilled the widespread belief, still deeply rooted culturally, that the justice system needs to be more democratic and transparent. Analyzing how meanings and expectations attributed to forensic genetic technologies in European postcommunist societies result from interactive social processes that project - but also dispute, silence, and negotiate - interpretations of the past, might provide an important area of future research in this field.

The European project is not only essential to ensure the mobility of people and goods, but also to enact and perform a certain "European way" (Barry, 2001). This idea of a "European way" is symbolically important. With the dissolution of the Soviet Union, the rhetorical possibility of a "new Europe" became fathomable - one that could bridge the East-West divide opened by the Cold War (Sellar, Staddon, \& Young, 2009). The acceptance of the socalled CEE countries into the EU was accompanied by deep societal reforms, but also by the enhanced possibility of travel for citizens seeking better opportunities in Western European countries. While the newest members of the European community might have shared a "utopia of return," the inclusion into the EU revealed persisting asymmetries between East and West. Therefore, as Marju Lauristin puts it, from a Western European perspective, these new members were to be regarded with suspicion and caution: "New members of the EU were viewed with suspicion, their values, lifestyles and interests were perceived as alien and 'non-European"' (Lauristin, 2007, p. 398). Consequently, after their transition to democracy, those countries that comprise the geopolitical region corresponding to the former Eastern Bloc - post-communist countries - have been a source of security concerns in Europe. The perception of weak border control in CEE countries raised fears that they would become "transit states for crime, drug trafficking, and immigration" (Friis \& Murphy, 1999, p. 224). As we have shown in this chapter, representations about the relationship between criminality and post-communist countries are assimilated and reaffirmed by the forensic geneticists interviewed in these CEE countries. Such an association clearly lays the foundations for expectations about the role of genetic technologies in the criminal justice system and the role of CEE countries within the Prüm system.

At the same time, the discourses of the forensic geneticists in the CEE countries pushed attention to the multiple forms in which historical and national specificities of post-communist societies contribute to what Astrid Mager (2017) names the "making and unmaking of a European identity" through technopolitical identities. Instead of speaking of a certain "European vision," we should instead look for Europe as a "multiply imagined community" in which powerful social actors are struggling to institutionalize their particular versions of Europe (Jasanoff, 2005, p. 10). The expectations of 
CEE forensic geneticists reveal deep entanglements between technoscientific and political arrangements by which surveillance has permeated the relationship between the state and the citizen well beyond the end of totalitarian and authoritarian regimes. In addition, the state expansive surveillance does not necessarily necessitate using cutting-edge technology in order to orchestrate control. The views of the forensic geneticists in post-communist countries showed that penetration of fear and of an overall culture of suspicion is longterm and even more pervading than sophisticated technologies of genetic surveillance. Thus, the expectations towards forensic genetic technologies offer the opportunity to analyze the re-negotiation of meanings on the transition from repressive past to democracy, but also the transition from non-technological to technological and genetics-based surveillance (Haggerty \& Samatas, 2010).

More research about the expectations related to the use of forensic genetics technologies in the context of criminal justice in CEE countries might allow the field of sociology, criminology and, of course, social studies of science and technology to become more inclusive. It is also needed to go beyond the theoretical and methodological lenses emerging from realities in the countries of the Northern and Central Europe. But in addition to allowing decolonization and democratization of knowledge, a study of this type also has the advantage of creating conditions to elucidate the way in which the North-West and the South-East are socially and historically interconnected and (dis)continued (Carrington et al., 2016; Pavlovich, 2018; Slade \& Light, 2015; Stone, 2018).

\section{Note}

1 See also the critical comments elaborated in other academic works, as for example (Bigo, 2008; Bigo \& Guild, 2005; Kuus, 2004; M'charek, Schramm \& Skinner, 2014).

\section{References}

Amelung, N., Granja, R., \& Machado, H. (2020). Modes of Bio-Bordering: The Hidden (Dis) Integration of Europe. London: Palgrave Macmillan. https://doi.org/ 10.1007/978-981-15-8183-0.

Barry, A. (2001). Political Machines: Governing a Technological Society. London: The Athlone Press. http://dx.doi.org/10.5040/9781474213110.

Beneduce, R. (2016). Traumatic pasts and the historical imagination: symptoms of loss, postcolonial suffering, and counter-memories among african migrants. Transcultural Psychiatry, 53(3), 261-285. https://doi.org/10.1177/1363461516645079.

Bernasco, W., Lammers, M., \& Van der Beek, K. (2016). Cross-border crime patterns unveiled by exchange of DNA profiles in the European Union. Security Journal, 29 (4), 640-660. https://doi.org/10.1057/sj.2015.27.

Bigo, D. (2008). EU Police Cooperation: National Sovereignty Framed by European Security? In E. Guild \& F. Geyer (Eds), Security Versus Justice? Police and Judicial Cooperation in the European Union (pp. 91-108). Aldershot: Ashgate. 
Bigo, D. \& Guild, E. (2005). Policing in the Name of Freedom. In D. Bigo, \& E. Guild (Eds), Controlling Frontiers: Free Movement into and Within Europe (pp. 113). Aldershot: Ashgate.

Boersma, K., Van Brakel, R., Fonio, C., \& Wagenaar, P. (Eds). (2014). Histories of State Surveillance in Europe and Beyond. London and New York: Routledge.

Broeders, D. (2007). The new digital borders of Europe. International Sociology, 22(1), 71-92. https://doi.org/10.1177/0268580907070126.

Bunce, V., McFaul, M., \& Stoner-Weiss, K. (2010) (Eds). Democracy and Authoritarianism in the Post-Communist World. Cambridge: Cambridge University Press.

Caparini, M. \& Marenin, O. (2005). Crime, insecurity and police reform in postsocialist CEE. The Journal of Power Institutions in Post-Soviet Societies, 2. https:// doi.org/10.4000/pipss.330.

Carrington, K., Hogg, R., \& Sozzo, M. (2016). Southern criminology. British Journal of Criminology, 56(1), 1-20. https://doi.org/10.1093/bjc/azv083.

Cohen, S. (1985). Visions of Social Control: Crime, Punishment and Classification. Cambridge: Polity Press.

Dimitrova-Grajzl, V. \& Simon, E. (2010). Political trust and historical legacy: the effect of varieties of socialism. East European Politics and Societies, 24(2), 206-228. https://doi.org/10.1177/0888325409353334.

Dunn, E. (2005). Standards and Person-Making in East Central Europe. In A. Ong \& S. J. Collier (Eds), Global Assemblages: Technology, Politics and Ethics as Anthropological Problems (173-193). Malden: Blackwell.

Friis, L. \& Murphy, A. (1999). The European Union and Central and Eastern Europe: governance and boundaries. Journal of Common Market Studies, 37(2), 211-232. https://doi.org/10.1111/1468-5965.00160.

Granja, R. \& Machado, H. (2019). Ethical controversies of familial searching: the views of stakeholders in the United Kingdom and in Poland. Science, Technology, \& Human Values, 44(6), 1068-1092. https://doi.org/10.1177/0162243919828219.

Gruszczyńska, B. (2004). Crime in Central and Eastern European countries in the enlarged Europe. European Journal on Criminal Policy and Research, 10(2-3), 123-136. doi:10.1007/s10610-004-3784-2.

Guild, E. \& Geyer, F. (Eds). (2008). Security Versus Justice? Police and Judicial Cooperation in The European Union. Farnham: Ashgate. https://doi.org/10.4324/9781315608136.

Haggerty, K.D. \& Samatas, M. (2010). Surveillance and Democracy. Oxford and New York: Routledge.

Halbwachs, M. (1980). Historical Memory and Collective Memory. In F. Ditter \& V. Ditter (Eds), The Collective Memory (50-87). New York: Harper \& Row Colophon Books.

Hignett, K. (2004). Organised crime in East Central Europe: the Czech Republic, Hungary and Poland. Global Crime, 6(1), 70-83. https://doi.org/10.1080/ 1744057042000297981.

Hignett, K. (2010). The changing face of organized crime in post-communist Central and Eastern Europe. Debatte: Journal of Contemporary Central and Eastern Europe, 18(1), 71-88. https://doi.org/10.1080/09651561003732520.

Holmes, L. (1997). Post-Communism: An Introduction. Durham: Duke University Press.

Hooghe, M. \& Quintelier, E. (2014). Political participation in European countries: the effect of authoritarian rule, corruption, lack of good governance and economic downturn. Comparative European Politics, 12(2), 209-232. https://doi.org/10.1057/ cep.2013.3. 
Horne, G. (2014). The Counter-Revolution of 1776: Slave Resistance and the Origins of the United States of America. New York: NYU Press.

Hosking, G. (2013). Trust and distrust in the USSR: an overview. Slavonic and East European Review, 91(1), 1-25. https://doi.org/10.5699/slaveasteurorev2.91.1.0001.

Hufnagel, S. \& McCartney, C. (Eds). (2017). Trust in International Police and Justice Cooperation. Oxford: Hart Publishing. http://dx.doi.org/10.5040/9781782257868.

Jasanoff, S. (2005). Designs on Nature: Science and Democracy in Europe and the United States. Princeton: Princeton University Press.

Jasanoff, S. \& Kim, S.-H. (Eds). (2015). Dreamscapes of Modernity: Sociotechnical Imaginaries and the Fabrication of Power. Chicago and London: University of California Press. https://doi.org/10.7208/chicago/9780226276663.001.0001.

Judt, T. (2009). The Past Is Another Country: Myth and Memory in Post-War Europe. In J. Müller (Ed.), Memory and Power in Post-War Europe: Studies in the Presence of the Past (157-183). https://doi.org/10.1017/cbo9780511491580.008.

Kuus, M. (2004). Europe's eastern expansion and the reinscription of otherness in East-Central Europe. Progress in Human Geography, 28(4), 472-489. https://doi.org/ 10.1191/0309132504ph498oa.

Lauristin, M. (2007). The European public sphere and the social imaginary of the 'New Europe'. European Journal of Communication, 22(4), 397-412. https://doi.org/ $10.1177 / 0267323107083058$.

Light, D. \& Young, C. (2009). European Union enlargement, post-accession migration and imaginative geographies of the 'New Europe': media discourses in Romania and the United Kingdom. Journal of Cultural Geography, 26(3), 281-303. https:// doi.org/10.1080/08873630903322205.

Los, M. (2003). Crime in transition: the post-communist state, markets and crime. Crime, Law and Social Change, 40(2-3),145-169. https://doi.org/10.1023/A: 1025788705613.

Luif, P. (2007, 17-19 May). The treaty of Prüm: A replay of Schengen? [Conference presentation]. European Union Studies Association, Tenth Biennial International Conference. Montreal.

Lyon, D. (2004). Globalizing surveillance: comparative and sociological perspectives. International Sociology, 19(2), 135-149. https://doi.org/10.1177/0268580904042897.

M'charek, A., Schramm, K., \& Skinner, D. (2014). Topologies of race: doing territory, population and identity in Europe. Science, Technology, \& Human Values, 39(4), 468-487. https://doi.org/10.1177/0162243913509493.

Machado, H. \& Granja, R. (2020). Forensic Genetics in the Governance of Crime. Singapore: Springer Singapore. https://doi.org/10.1007/978-981-15-2429-5.

Machado, H., Granja, R., \& Amelung, N. (2020). Constructing suspicion through forensic DNA Databases in the EU. The views of the Prüm professionals. The British Journal of Criminology, 60(1), 141-159. https://doi.org/10.1093/bjc/azz057.

Mager, A. (2017). Search engine imaginary: visions and values in the co-production of search technology and Europe. Social Studies of Science, 47(2), 240-262. https://doi. org/10.1177/0306312716671433.

Mawby, R. (2000). The changing face of policing in Central and Eastern Europe. International Journal of Police Science \& Management, 2(3), 199-216. https://doi. org/10.1177/146135570000200302.

Mawby, R.C. \& Gisby, W. (2009). Crime, media and moral panic in an expanding European Union. The Howard Journal of Criminal Justice, 48(1), 37-51. https://doi. org/10.1111/j.1468-2311.2008.00547.x. 
McLean, S.J., Worden, R.E., \& Kim, M. (2013). Here's looking at you: an evaluation of public CCTV cameras and their effects on crime and disorder. Criminal Justice Review, 38(3), 303-334. https://doi.org/10.1177/0734016813492415.

Mesko, G., Fields, C.B., Lobnikar, B., \& Sotlar, A. (2013). Handbook on Policing in Central and Eastern Europe. New York: Springer. https://doi.org/10.1007/978-1-4614-6720-5.

Ong, A. \& Collier, S.J. (2005). Global Assemblages: Technology, Politics, and Ethics as Anthropological Problems. Malden: Blackwell.

Pavlovich, W.V. (2018). Noxious geopolitics, festering populaces and transmutable pasts: reframing the limits of acceptable politics through European refugee crises. Patterns of Prejudice, 52(2-3),244-269. https://doi.org/10.1080/0031322X.2018.1433023.

Reed, K. \& Syndercombe-Court, D. (2016). A Comparative audit of legislative frameworks within the European Union for the collection, retention and use of forensic DNA profiles. EUROFORGEN - NoE. London. Retrieved from https://www. euroforgen.eu/fileadmin/websites/euroforgen/images/Dissemination_Documents/ WP4/Reed_and_Syndercombe_Court_2016_Legal_Audit.pdf.

Reiner, R. (2010). The Politics of the Police (4th ed.). Oxford: Oxford University Press. https://doi.org/10.1093/he/9780199283392.001.0001.

Richterova, D. (2018). Terrorists and revolutionaries: the Achilles heel of communist surveillance. Surveillance \& Society, 16(3), 277-297. https://doi.org/10.24908/ss. v16i3.6958.

Rothschild, J. \& Wingfield, N.M. (Eds) (2007). Return to Diversity. A Political History of East Central Europe since World War II. New York and Oxford: Oxford University Press.

Santos, F. (2017). The Transnational Exchange of DNA Data: Global Standards and Local Practices. In K. Jakobs \& K. Blind (Eds), Proceedings of The 22nd EURAS Annual Standardisation Condeference. Digitalisation: Challenge and Opportunity for Standardisation (305-322). Aachen: Verlag Mainz.

Santos, F. \& Machado, H. (2017). Patterns of exchange of forensic DNA data in the European Union through the Prüm system. Science \& Justice, 57(4), 307-313. http s://doi.org/10.1016/j.scijus.2017.04.001.

Santos, F., Machado, H., \& Silva, S. (2013). Forensic DNA databases in European countries: is size linked to performance? Life Sciences, Society and Policy, 9(12), 113. https://doi.org/10.1186/2195-7819-9-12.

Schwartz, S. \& Bardi, A. (1997). Influences of adaptation to communist rule on value priorities in Eastern Europe. Political Psychology, 18(2), 385-410. https://doi.org/10. 1111/0162-895X.00062.

Šelih, A. \& Završnik, A. (Eds). (2012). Crime and Transition in Central and Eastern Europe. London and New York: Springer. https://doi.org/10.1007/978-1-4614-3517-4.

Sellar, C., Staddon, C., \& Young, C. (2009). Twenty years after the wall: geographical imaginaries of 'Europe' during European Union enlargement. Journal of Cultural Geography, 26(3), 253-258. https://doi.org/10.1080/08873630903322189.

Siegel, D. (2014). Lithuanian itinerant gangs in The Netherlands. Kriminologijos Stud, 2(2014), 5-40. https://doi.org/10.15388/CrimLithuan.2014.2.5088.

Skinner, D. (2018). Race, racism and identification in the Era of Technosecurity. Science as Culture, 29(1), 77-99. https://doi.org/10.1080/09505431.2018.1523887.

Slade, G. \& Light, M. (2015). Crime and criminal justice after communism: Why study the post-Soviet region? Theoretical Criminology, 19(2), 147-158. https://doi. org/10.1177/1362480615571724. 
Spülbeck, S. (2000). Ethnography of an encounter: reactions to refugees in post-war Germany and Russian migrants after the reunification - context, analogies and changes. Journal of Communist Studies and Transition Politics, 16(1-2),175-190. https://doi.org/10.1080/13523270008415436.

Stone, D. (2018). On neighbours and those knocking at the door: holocaust memory and Europe's refugee crisis. Patterns of Prejudice, 52(2-3),231-243. https://doi.org/ 10.1080/0031322X.2018.1433038.

Svenonius, O. \& Björklund, F. (2014). Surveillance, lustration and the Open Society: Poland and Eastern Europe. In K. Boersma, R. Van Brakel, C. Fonio, \& P. Wagenaar (Eds), Histories of State Surveillance in Europe and Beyond (115-137). New York: Routledge.

Svenonius, O. \& Björklund, F. (2018). Explaining attitudes to secret surveillance in post-communist societies. East European Politics, 34(2), 123-151. https://doi.org/10. 1080/21599165.2018.1454314.

Svenonius, O. \& Tarasova, E. (2021). "Now we are struggling at least": change \& continuity of surveillance in post-communist societies from the perspective of data protection authorities. Surveillance \& Society, 19(1), 53-68. https://doi.org/10.24908/ ss.v19i1.13477.

Sztompka, P. (1996). Looking back: the year 1989 as a cultural and civilizational break. Communist and Post-Communist Studies, 29(2), 115-129. https://doi.org/10. 1016/S0967-067X(96)80001-80008.

Sztompka, P. (2000). Cultural trauma: the other face of social change. European Journal of Social Theory, 3(4), 449-466. https://doi.org/10.1177/136843100003004004.

Taverne, M. \& Broeders, A.P.A. (2015). The Light's at the End of the Funnel! Evaluating the Effectiveness of the Transnational Exchange of DNA Profiles Between the Netherlands and other Prüm Countries. Zutphen: Paris Legal Publishers.

Taverne, M. D. \& Broeders, A.P.A. (2017). Cross-border patterns in DNA matches between the Netherlands and Belgium. Science \& Justice, 57(1), 28-34. https://doi. org/10.1016/j.scijus.2016.08.008.

Vaduchova, M. (2015). External actors and regime change. How post-communism transformed comparative politics. East European Politics and Societies: and Cultures, 29(2), 519-530. https://doi.org/10.1177\%2F0888325415571411.

Van Daele, S. (2008). Organised property crimes in Belgium: the case of the 'itinerant crime groups'. Global Crime, 9(3), 241-247. https://doi.org/10.1080/17440570802254346.

Verovšek, P.J. (2016). Collective memory, politics, and the influence of the past: the politics of memory as a research paradigm. Politics, Groups, and Identities, 4(3), 529-543. https://doi.org/10.1080/21565503.2016.1167094.

Waever, O. (2000). The EU as a Security Actor: Reflections from a Pessimistic Constructivist on Post-Sovereign Security Orders. In M. Kelstrup, \& M. Williams (Eds), International Relations Theory and the Politics of European Integration: Power, Security, and Community (250-294). London and New York: Routledge.

Wilson, T. (2016). Criminal justice and global public goods: the Prüm forensic biometric cooperation model. The Journal of Criminal Law, 80(5), 303-326. https://doi. org/10.1177/0022018316668450.

Wittenberg, J. (2015). Conceptualizing historical legacies. East European Politics and Societies: and Cultures, 29(2), 366-378. https://doi.org/10.1177/0888325415577864.

Wolff, L. (1994). Inventing Eastern Europe. The Map of Civilization on the Mind of Enlightenment. Stanford: Stanford University Press. 


\title{
5 The Uses of Familial Searching In Europe
}

\author{
At The Crossroads Between Expanding \\ Suspicion And Historical Reparation
}

\section{Introduction}

Between 1983 and 1986 a string of violent attacks and rapes were perpetrated using the same modus operandi. The victims were middle-aged women, aged between 18 and 54, returning home alone in the early hours of the morning from a night out in the Rotherham area of South Yorkshire, England. The perpetrator always took his victim's shoes and was nicknamed by the media as the "Shoe rapist." Several suspects were detained for questioning at the time, but the cases remained unsolved.

Twenty years later, the case was reopened. Using DNA samples collected from the crime scenes and from victims' bodies, familial searching in the British National DNA Database (NDNAD) produced a list of 43 people who might be related to the rapist. The third person investigated by the police, June Lloyd, had a DNA sample stored in the NDNAD in connection with a drink-driving offence. Immediately following police contact, she called her brother, James Lloyd, warning him that officers would be asking him to provide a swab. Within hours, James Lloyd had called his father to confess having committed serious offences. When police searched the premises of his workplace, they discovered 124 shoes hidden in a crawl space. ${ }^{1}$

The Shoe Rapist is one of the first criminal cases in the United Kingdom to be successfully prosecuted based on familial searching. Familial searching is a genetic technique that works on the assumption that DNA is inherited and that members of biologically related families share variable amounts of genetic material. This technique focuses on finding close matches between DNA profiles, rather than perfect matches. The Shoe Rapist case has been repeatedly referenced and remains a significant example in discussions around familial searching as a kind of "founding myth" (Prainsack \& Toom, 2013) for this specific investigative technique. By highlighting certain elements in this narrative, presenting only those that lead towards finding "truth" and demonstrating the technological advantages for justice, such cases serve to remove uncertainties and ethical concerns about the usefulness of biological connections in identifying crime perpetrators, thus further contributing towards reproducing

DOI: $10.4324 / 9780429261435-5$ 
narratives that portray "technologies as objective and neutral methods for solving societal problems" (Prainsack \& Toom, 2013, p. 72).

Familial searching is used for two primary purposes: advancing criminal investigations and assisting civil identification (see Table 5.1). In criminal investigations, the aim is to identify criminal suspects by finding close matches through the DNA profile of their relatives. When close matches exist, there is a probability that the profile obtained at the crime scene, or from the victim(s), belongs to a close relative of the person in the database - usually parents, children, or siblings. For civil identification purposes, the same technical principle holds true (to identify close matches), but in this instance the aim is to help the search for missing persons and/or the identification of unidentified bodies. Procedures that use DNA have become increasingly relevant among the set of technologies and strategies used to match unidentified bodies and/or persons with individuals thought to be their biological relatives, such as dental records, radiographs, and photographic comparisons.

Civil identification, namely in its uses for identification of human remains and war crimes in post-conflict settings (Gandsman, 2012; Garibian, 2014; Moon, 2013), is generally valued and associated with its role in "dignifying" both the dead and the living. In such contexts, familial searching also enables forms of sense-making and resignification of past violence and present-day human atrocities (Schwartz-Marín \& Cruz-Santiago, 2017), while at the same time facilitating the search for family members in processes of truth-making and reconciliation with the brutality of disappearance, torture, kidnapping, and even death of loved ones caused by repressive political regimes and dictatorships. Thus, in the field of civil identification, DNA-led identification tends to represent a mechanism for (re)constituting democracy - that is,

Table 5.1 Types of familial searches

\begin{tabular}{|c|c|c|c|}
\hline Purposes & $\operatorname{Aim}(s)$ & Data sources & Affected publics \\
\hline \multirow[t]{3}{*}{$\begin{array}{l}\text { Criminal } \\
\text { investigation }\end{array}$} & $\begin{array}{l}\text { Identify criminal } \\
\text { suspects }\end{array}$ & $\begin{array}{l}\text { Criminal DNA } \\
\text { databases }\end{array}$ & $\begin{array}{l}\text { Criminalized } \\
\text { groups and close } \\
\text { biological relatives }\end{array}$ \\
\hline & & $\begin{array}{l}\text { Intelligence-led } \\
\text { DNA massive } \\
\text { screenings }\end{array}$ & $\begin{array}{l}\text { Civil society and } \\
\text { close biological } \\
\text { relatives }\end{array}$ \\
\hline & & $\begin{array}{l}\text { Partial matching } \\
\text { Conducted ad hoc, } \\
\text { in the laboratory }\end{array}$ & $\begin{array}{l}\text { Profiled indivi- } \\
\text { duals in a given } \\
\text { criminal investiga- } \\
\text { tion and close } \\
\text { biological relatives }\end{array}$ \\
\hline Civil identification & $\begin{array}{l}\text { Humanitarian ends } \\
\text { Historical } \\
\text { reparation }\end{array}$ & $\begin{array}{l}\text { Missing persons } \\
\text { DNA databases }\end{array}$ & $\begin{array}{l}\text { Missing persons } \\
\text { and close biologi- } \\
\text { cal relatives }\end{array}$ \\
\hline
\end{tabular}

Source: Authors. 
certain modes of governance, justice, and accountability, through the biology of the victims (Smith, 2016).

Besides its twofold purpose, familial searching can also be used in different data sets. The first of these, as outlined in the Shoe Rapist case, involves conducting searches in criminal DNA databases to identify criminal suspects by using their genetic connection to biological relatives (Debus-Sherrill \& Field, 2019; Granja \& Machado, 2019; Haimes, 2006; Kim et al., 2011; Suter, 2010). The second dataset in which familial searching can be used are intelligence-led DNA mass screenings (Thomas, 2006). That is, procedures involving the collection of DNA samples from "volunteers" within specific population groups, to search for potential suspects believed to belong to those groups, by matching samples with those collected from a crime scene/victim. Another variant of familial searching might also occur in situations where laboratory practitioners find an inadvertent partial match while looking for a perfect correspondence between a certain DNA profile and the biological material found at a crime scene (Murphy, 2010, p. 9) - what Sara DebysSherril and Michael Field call "partial matching" (Debus-Sherrill \& Field, 2019). With regard to civil identification, familial searching is generally conducted in databases for civil identification purposes that aggregate profiles from unidentified individuals, human remains, and missing persons with profiles from biological relatives looking for missing family members.

Each of these different datasets configures specific affected publics (see Table 5.1). In the case of criminal DNA databases, the affected publics are criminalized groups (whose profile inclusion in DNA databases is mandatory), as well as their close biological relatives. The use of mass screenings affects individuals in civil society who, regardless of their involvement with the criminal justice system, "voluntarily" accept to participate, although the voluntary nature of this procedure will be a topic of discussion throughout this chapter. This kind of participation implies subjects acknowledging the potential effects upon their close biological relatives. In the case of partial matching, conducted ad hoc in the laboratory, the group of affected individuals is reduced, since only those who were profiled within a particular case, and their biological relatives, are involved. Finally, familial searches conducted for civil identification purposes affect both the missing - whether dead or alive -, and their close biological relatives. All the types of familial searching mentioned above make use of Short Tandem Repeat (STR), the socalled "non-coding genes" that presumably hold little value other than for identification purposes (Cole, 2007b) and usually identify close relatives, such as parents, siblings, or children.

Based on a set of qualitative interviews conducted with forensic geneticists working in fourteen European countries, in this chapter we will explore how these professionals perceive the ethical controversies, regulatory challenges, and logistical issues posed by familial searching. Most of our participants refer to the uses of familial searching applied to criminal investigations. However, a small group of the forensic geneticists interviewed also reflect 
upon the implications of familial search uses for civil identification purposes. Within this framework, we show how forensic geneticists' discourses around familial searching provide insights into broader trends that outline a merge of human-rights forensics with a security-focused DNA identification (Smith, 2017). This movement shows that the increasing expansion of forensic sciences market and commercial interests, fuelled by ideological concerns about the "global threats" of terrorism and crime, construct the legitimation of DNA identification efforts within an increasing focus on security (Smith, 2017). Within this scenario, we explore the possibility of locating familial searching at the intersection between apparently opposite but simultaneously mutually constitutive rationales - the expansion of suspicion and the care for the missing - while also describing the implications of those rationales' increasing embeddedness in the architectures of genetic surveillance.

\section{Legislation and ethical issues of familial searching}

Familial searching in criminal DNA databases was first implemented in the UK in 2002 (Haimes, 2006; Prainsack, 2010) and its use has since been expanding to other countries. The Netherlands (Simoncelli, 2006) and France (Pham-Hoai, Crispino, \& Hampikian, 2014) introduced legislation allowing the use of this investigative technique and, more recently, Germany has also approved the use of familial searching in intelligence-led DNA mass screenings (Amelung, Granja, \& Machado, 2020). In other European Union countries, the situation remains unclear, although criminal cases involving the use of DNA from relatives to search for criminal suspects have been recorded in countries such as Spain (Phillips et al., 2017), Poland (Dettlaff-Kakol \& Pawlowski, 2002), and Italy (Jones, 2015).

Countries where familial searching in forensic DNA databases is regulated, guidelines are typically restrictive and only allow its use in criminal cases considered serious and whose solution has proved difficult by other means (Chamberlain, 2012). For example, familial searches conducted by the UK's NDNAD are analysed on a case-by-case basis, subject to permission from the Chairman of the NDNAD Strategy Board and, in some cases, from the victim (Maguire et al., 2014). Therefore, only a reduced number of criminal cases are approved to use familial searches in forensic DNA databases. Since 2012 some 120 cases have been authorized for familial searches in the UK and out of these, nine have been solved through this technique (Biometrics and Forensics Ethics Group, 2020, p. 11).

The great bulk of scientific publications on the topic of familial searching has come from the field of socio-legal studies, addressing the ethical issues posed by the use of this investigative technique (García, Crespillo, \& Yurrebaso, 2017; Haimes, 2006; Kim et al., 2011; Murphy, 2010; Suter, 2010), namely threats to genetic privacy, sensitive information disclosure, and reproduction of social inequalities (Machado \& Granja, 2020). The debate over genetic privacy revolves around the question of whether familial searching increases indirect 
surveillance on a certain group of individuals - relatives of potential suspects primarily on the basis of their genetic association with someone (Greely et al., 2006). Sensitive information disclosure poses the problem of a latent risk of revealing information implied in the use of familial searching. This problem applies both in the absence or existence of genetic relations (Suter, 2010) and/or information regarding a person's involvement with the criminal justice system previously unknown to other parties. Finally, the reproduction of social inequalities is discussed in relation to the potential of this technique to reinforce dominant views about the alleged prevalence of criminality within certain families (Haimes, 2006). Moreover, it also touches upon familial searching's potential to further reproduce the criminalization of certain social groups by extending the reach of criminal DNA databases (Murphy, 2010) which generally over represent those groups and social categories that are especially affected by criminal justice system activity, such as racial and ethnic minorities (Skinner, 2013).

Despite the lively debate stirred around familial searching over the years, empirical studies on this topic remain scarce. One exception is the study conducted on a national survey of CODIS Laboratories in the United States of America about policies, practices and professionals' views of familial searching (Debus-Sherrill \& Field, 2019). Results show that while perceptions of familial searching were generally positive - most respondents ( 87 per cent) showing a belief in this technique's potential to assist investigations - participants nonetheless shared several concerns regarding familial searching. In addition to resources issues, appearing as the main concern, 83 per cent of respondents working in a lab where familial searching was conducted reported concerns over the risks for civil liberties, against the 30 per cent registered among respondents working in labs that do not conduct this genetic technique (Debus-Sherrill \& Field, 2019).

In our previous work about familial searching in Europe, we focused on the uses of this technique in the UK and Poland. More specifically, we outlined the variability of familial searching in terms of meanings, uses, and regulations (Granja \& Machado, 2019). In the UK, familial searching is regulated on a basis of exceptionality. That is, familial searching can only be used in criminal cases that are considered serious and have proved difficult to solve by other investigative means. They must go through a process of selection and oversight by a regulatory body whose public accountability serves to reinforce the public trust. In Poland, familial searching is regulated within the framework designed to expand the scope of its applicability in the search and/or identification of missing persons. As a nation marked by a historical legacy of missing persons, their identification is framed as an ethically uncontested public good. Actions taken towards identification of missing persons are therefore accepted as the kind of public intervention that is conducive to modes of governance and justice aligned with the establishment and the consolidation of an accountable state (Granja \& Machado, 2019). In this work we also demonstrated how familial searching prescribes specific notions of 
social risk, public good, and state accountability. This chapter intends to expand on this approach, considering the discourses of forensic geneticists based in 14 different European countries. Namely, we focus, on how the shifts between familial searching for criminal investigation and for historical reparation of past violence coproduce different perceptions of ethical controversies surrounding familial searching that carry the weight of sociohistorical and techno-political backgrounds, as well as contingent and circumstantial notions regarding the socially legitimate uses of genetic technologies among different societies.

\section{Criminal investigation: expanding suspicion}

\section{Perceived ethical issues and logistical challenges}

The main debate on the impacts of forensic DNA technologies is focused on how it affects profiled individuals (suspects, convicted, etc.) (Hindmarsh \& Prainsack, 2010). However, familial searching demonstrates heightened collateral interference on the biological relatives of profiled individuals. This is a central theme in the discourses of participants, who critically reflect upon the wide ethical range of implications. One of the most discussed topics among participants is the latent risk of sensitive information disclosure (Haimes, 2006; Kim et al., 2011; Suter, 2010). The forensic geneticists we have interviewed expressed significant concerns about the potential revelation of genetic information that challenges relationships in ways which might produce disruptive implications in established kinship structures. In the words of a participant:

More than 25 per cent of offspring, that is, sons and daughters, are not from the [biological] family. (...) So, familial searching can pose a high risk and a problem. (...) A problem of who and how [to] handle this information [regarding kinship]. (...) Because you really can destroy the whole family. It is a high risk for me.

(Interview L02)

Nonetheless, according to the participants in our study, the risk of disclosing information does not imply ignoring or dismissing the forensic usefulness of familial searching. Its acknowledgement is the basis of a perceived need to develop anticipatory approaches and practices (Wienroth, 2018) to avert such a risk. The following excerpt is by an interviewee who discusses the need to establish a protocol for such cases, describing how practitioners should proceed when they find this type of information. In his view, the management of such information should fall upon prosecutors rather than forensic geneticists. The responsibility for deciding what to do with such information is thereby displaced from the production of knowledge and diffused into the realm of the criminal justice system, specifically assigning it to the prosecution, in such a way as to protect the autonomy and legitimation of forensic genetics (Granja \& Machado, 2020). 
I have been involved in many cases where reference material was provided from relatives, but in many instances it turned out that these relatives were not truly relatives (...) where the legal father is not the biological father. So I think this is a general problem, and we need to be aware and prepared for it. But still, I think it should not be restricted, this is the type of information can be very useful in many cases. (...) The question is what we should do with this kind of information. Of course, prosecution should be informed about this, because they provided the reference samples. What should they do with this information, do they inform the father about this? I don't know, it's not my task (...) I simply report to the prosecutor.

(Interview G10)

The perceived risks of revealing information about genetic relationships derives from the relational nature of familial searching. That is, by making use of genetic connections between individuals, familial searching moves away from an approach that characterizes bodies as individuated and unique entities (Cole, 2009) to a relational framework that connects bodies (and identities) through genetic data. This relationality implies that a body is not an individual entity: it stands in association with other genetically connected bodies, even if they are physically removed at a given space and time frame. This process is achieved by actively constructing genetic ties between individuals (biological relatives), with the corresponding social sorting, that is, bodies are framed within police categories (suspect/not suspect) that produce critical implications for social life, i.e., (non) involvement with the criminal justice system. Familial searching thereby sheds light into how forensic science relates the individual with the collective (M'charek \& Wade, 2020). The forensic geneticists interviewed consider this relational character of familial searching as ethically challenging, inasmuch as this forensic genetics technique directly interferes with citizens' right to genetic privacy. According to the following interviewee, conducting familial searching in criminal DNA databases implies a transgression of the consent given by individuals who were profiled, who might not have been aware that their DNA would be used to identify biological relatives. As manifested by an interviewee:

We can set up dragnets; we can run the databases to search, not for individuals, not for matches between individuals, but for presumable relatives of [unknown criminal suspect] ... And that is absolutely inadmissible, because it violates all the things that were agreed and contracted upon construction of [a DNA database]. Namely, the informed consent. So, you are releasing information on your relatives and there is no way to make you responsible for that. So that kind of analysis is really difficult to manage and to tolerate. 
The use of familial searching in forensic DNA databases, therefore, fuels the debate about the rights and duties of the "genetic informant"; the person whose sample is a partial match with the crime scene sample and who unintentionally implicates family members in criminal investigations (Gabel, 2010; Murphy, 2010; Suter, 2010). According to interviewees, besides infringing citizens' right to genetic privacy, the role of the genetic informant is also highly contentious as it directly interferes with the right to refuse testifying against one's relatives.

I believe we have to lead a very serious discussion with law experts and wider society if we are to contemplate this option. Because under [national] laws, it is written that no one can be forced testify against relatives. In the case of first degree relatives, like a father, son, brother or sister, a person can refuse to be summoned as a witness and appear in court to testify. And I think the same should also apply, as a rule, to genetics. Because if you want to change that, then there must be a very good reason to do it.

(Interview O01)

One other topic discussed by the forensic geneticists when considering the ethically challenging character of familial searching, regards its discriminatory potential. The rationale underlying familial searching, i.e. searching for criminal suspects through relatives who have a history of contact/involvement with the criminal justice system, echoes a dominant notion - circulating across various spheres of social life - which broadly associates family and crime (Rose, 2000). According to participants in this study, the link between crime and family is ethically problematic, inasmuch as it could end up reinforcing pre-existing notions and assumptions pointing to the alleged prevalence of crime and criminal behaviour in certain families (Haimes, 2006). According to the following interviewee, referring to concerns about the problematic association made by police in thinking that "crime can have family links," familial searching creates two kinds of citizens, corresponding to different entitlements in relation to genetic privacy.

It's like producing two types of citizens, those who have relatives on the database and those who don't. They don't have the same rights. The police think crime can have family links. So, they assume a potential criminal link between individuals; the element of kinship leads to positive discrimination, in terms of information, for individuals whose relatives are not registered in the relevant databases. I don't think that's fair, I'm against it. As an individual, I don't think it should be allowed. (...) For that effect I prefer a database including the entire population.

(Interview C05)

Considering the discriminatory potential of familial searching and its power to reinforce notions of genetic sameness in discourses aligned with a 
dominant narrative of risky and suspect communities (Skinner, 2006, 2018), this interviewee considers that a universal DNA database would be preferable (Bieber, Brenner, \& Lazer, 2006; Greely et al., 2006; Thomas, 2006). This view is reasserted by other participants who, considering how familial searching might render right to privacy more vulnerable, equate the possibility of creating a universal genetic database for the whole resident population. However, such possibilities raise other issues, such as the potential misuse of genetic data and the increased incidence of surveillance. In the words of one participant:

[Regarding familial searching] the easiest way to get all the information would be to have surveillance over everyone: to profile everybody. That would be the best for the police. (...) it would be useful insofar as getting the right person in jail, but on the other hand it implies that you have innocent people and you are searching through them. I don't know how I would feel about having no idea what manipulations are being done with my [DNA] data somewhere. I wouldn't know what was being searched, investigated, what was going on. It really is something that would make one feel to be constantly monitored.

(Interview S04)

In addition to the ethical issues, participants recurrently mentioned the logistical challenges posed by familial searching. This investigative technology requires a significant allocation of economic, temporal, and human resources needed to search, review, and refine the selection and follow up the pool of potential suspects (Flaus, 2013; Greely et al., 2006; Kim et al., 2011) and it can produce lists of hundreds of potential suspects (Bieber et al., 2006; Kruijver, 2016), many of whom might be false positives ${ }^{2}$ (Thomas, 2006). According to participants, besides considering the ethical challenges posed by familial searching, this is a technique that implies taking into account availability of resources.

The size of the database, the number of people in it, how we're likely to find several candidates we need to investigate, knowing in advance that probably only one of the candidates is related. So, I feel that is where the biggest conflict resides. I think that's the greatest challenge.

(Interview C01)

Familial search takes a lot of time, the success rate is relatively low, below $10 \%$ or maybe only a very small percentage, and it means a lot of laboratory time. Sometimes hundreds of samples, potentially thousands of samples.

(Interview P02)

Considering Europe's highly differentiated context in terms of staff and infrastructures available for forensic science (Amelung et al., 2020) it is clear that not all countries have the capacity to allocate the required resources to 
conduct familial searching. However, willingness to conduct familial searching does not reflect only the existence of material and concrete infrastructure and resources. Complex layers have to be considered when addressing the uses of familial searching in Europe, namely social, historical, and political aspects that will influence whether using familial searching is justified or unjustified. Elsewhere we have demonstrated how the controversies surrounding familial searching are closely entangled with notions of social risk, public good, and accountability of the state, which tend to vary across countries (Granja \& Machado, 2019). In addition, national jurisdictions have differentiated legislation and regulation that might be more or less prone to accommodate the uses of familial searching, as we will discuss in more detail in the next section of this chapter.

\section{Regulation (or lack thereof)}

As previously mentioned, familial searching has a different regulatory framework throughout Europe. While some countries have created a particular legislative framework, such as the Netherlands, the UK, France, and Germany, others lack any regulation. The regulatory gap usually derives from the obsolescence of legislation created when a division between the coding and non-coding region of DNA was still scientifically sustained (Cole, 2007a). Familial searching, as well as other recent forensic DNA technologies, challenge such a division.

For forensic geneticists, the variability found across Europe in terms of familial searching regulation poses a challenge because, on the one hand, it runs counter international standardization trends and, on the other, it leaves ample room for interpretation in countries where regulation is absent. According to a participant:

The decision makers - politicians, lawyers and ethicists - are not completely sure of how it is applied in different countries. So, the framework is very... different; countries do different things. And if you talk to people in [country], they say: "Sometimes we do it, sometimes we don't." Well, what does that mean? (...) I think that creates problems just to know what is happening.

(Interview C04)

In cases where the possibilities created by familial searching are not addressed by existing regulatory provisions, several ethical dilemmas emerge. That is, in countries where explicit regulation is lacking, experts and practitioners might either interpret the perceived regulatory gaps as license to practice familial searching or as implicitly limiting. This ambiguity is illustrated by the following interviewee:

It may be just as likely that this kind of information is allowed in court or not. Actually, we are in a bit of a limbo, we do not know whether this is allowed or not. 
This ambiguity sets the framework for what Peter Fussey and Ajay Sandhu (2020) call "surveillance arbitration," where practitioners are given a wide scope to interpret regulations and adapt their activities accordingly (Fussey \& Sandhu, 2020). Surveillance arbitration, therefore, implies that even in countries where familial searching is forbidden or non-regulated, there might be attempts to use this investigative technique. This is reported by one of our interviewees, detailing requests in this kind of scenario:

I think that, providing a sufficiently important case pops up, it is going to happen (...) I get emails from countries where familial searching is certainly not allowed, from countries where they are not supposed to have any databases with this, but obviously what happens is that, if the case is sufficiently important or if it is related to, say, terrorism, this is going to happen anyway. I mean, there are cases where they kind of bypass the law.

(Interview Q02)

Finally, there are also cases in which regulation is a work-in-process. This "regulatory lag" (Fussey \& Sandhu, 2020) usually stems from the fact that technological capabilities emerge at a faster pace than the legislative process, as outlined by one of the interviewees: "You know, often the science moves much faster than the legislative process" (Interview D12). It also applies in the case of countries where the legislation in the process of moving from considering familial searching illegal to allowing the use of these techniques, as explained in the following excerpt:

In some cases, they [police officers] wanted to [use familial searching], but it is really not legal. But they knew about the techniques. So, in some cases, when they have really extremely high-class cases, top cases, they send [samples] and ask: "If it is possible please do some familial search because we are lost." (...) The project has been finished, we have finalized all conclusions, so the methodology is available. But we have to wait they have to wait -until the legislative background is available. We have the modification of the actual database law in that sense, that it allows this kind of service.

(Interview P02)

Regardless of the regulatory landscape in each particular country - regulated, regulatory gap, or on-going regulation - it is clear that one major factor influencing the existence or absence of regulation on familial searching is the occurrence of high-profile criminal cases that can be used to justify and legitimize its implementation. In this context, it is important to recall the rape and murder of Marianne Vaastra, which has become a "paradigmatic case" in the Netherlands, owing to the array of debates involved (M'charek, Toom, \& Jong, 2020). In 1999 a girl named Marianne Vaatstra was murdered in a 
rural area in the Netherlands. In 2007, following the advice of an expert from a private forensic services company, Marianne's father pushed for familial searching. At the time, the use of this forensic genetic technique was not legally permitted in the Netherlands. However, familial searching technology was considered particularly suitable to the Vaatstra case. Consequently, several parties involved in the case began to push for the regulation of this technology, as explained by the following participant:

Take the Marianne Vaastra case as one of the examples for why we should accept kinship techniques. The beauty of the case was that it provided all the practical examples for considering it a good idea, at the same time showing that issues of privacy didn't really apply.

(Interview A07)

High-profile cases are construed by contemporary societies as public, crime and justice-related dramas, to a large extent influenced and fueled by media narrative constructions whose purpose is to summon emotional public support by appealing to feelings of compassion and sympathy for the victims while at the same time nourishing feelings of moral repulsion towards criminal suspects (Machado \& Santos, 2009). As recognized by the following interviewee, such cases thus function as the perfect outlet to demonstrate the potential benefits of using a particular technology designed to identify criminal suspects, in ways that capture public support.

If you go back to the source and ask yourself: "Well, what is the difference between Marianne Vaastra and, let us say, another case nobody ever heard of?" Well, the only difference is that this type of cases exploded in the media and were put under a magnifying lens. And because of that, everybody gets nervous, annoyed, and impatient to get it solved.

(Interview A07)

In 2012 the use of familial searching was approved in the Netherlands, aligned with this country's track record of innovation regarding the regulation and practical application of genetic technologies for forensic purposes (Amelung et al., 2020). In the light of this, although familial searching was not the key-technology responsible for identifying the suspect in the Vaatstra case, it remained relevant as this was the criminal case responsible for pushing the regulation of the investigative technique forward in the Netherlands (Winter et al., 2019).

Other countries, where the use of familial searching is regulated, have also reported high-profile cases in which familial searching played a role, such as the case of Elodie Kulik in France (Pham-Hoai et al., 2014) and several cases in the UK (Williams \& Johnson, 2006), such as the case of the Shoe Rapist mentioned at the beginning of this chapter. In Germany - a country where familial searches are forbidden in the national DNA database, but allowed in 
mass screenings - the influence of high-profile criminal cases to change regulation is also visible. The German legislative framework in this area can be traced to a criminal case occurred in the northern German town of Dörpen, where a mass screening was conducted on the aftermath of a rape case. Partial matches between crime-scene DNA profiles of the perpetrator and of the brothers' profiles led to the identification of a young man as a prime suspect (Roewer, 2013, p. 7). In 2012 Germany's Federal Constitutional Court ruled against future use of evidence derived from familial searching in court. However, in November 2013 the German government decided to legalize familial searching when used as part of a DNA dragnet (Lee, 2016, p. 218). This decision was controversial, in view of the court ruling from the previous year, determining the lack of any legal basis for using familial searching in that context (Lee, 2016, p. 218). Yet, in 2017, the legislator legalized familial searching with the "DNA-Beinahetreffer." Table 5.2 provides a synthesis of diverse topics related to regulation and practices surrounding familial searching in Europe.

In sum, there is a complex regulatory scenario across Europe, influenced by the variable balances between the weight of sociohistorical backgrounds and trajectories of implementing forensic genetic technologies in criminal identification. This opens scenarios of surveillance arbitration (Fussey \& Sandhu, 2020) - that is, forensic practitioners face a wide latitude to interpret regulations (or lack thereof) regarding familial searching and therefore adapt their

Table 5.2 Familial searching in criminal investigation

\begin{tabular}{|c|c|c|c|c|c|}
\hline Regulation & $\begin{array}{l}\text { Influencing } \\
\text { factors }\end{array}$ & $\begin{array}{l}\text { Type of } \\
\text { search }\end{array}$ & Countries & Benefits & Risks \\
\hline \multirow[t]{2}{*}{$\begin{array}{l}\text { Existing } \\
\text { Regulation }\end{array}$} & \multirow{2}{*}{$\begin{array}{l}\text { Track record of } \\
\text { 'innovation' } \\
\text { regarding the } \\
\text { regulation and } \\
\text { practical appli- } \\
\text { cation of } \\
\text { genetic tech- } \\
\text { nologies for } \\
\text { forensic pur- } \\
\text { poses } \\
\text { Role of high- } \\
\text { profile criminal } \\
\text { cases in push- } \\
\text { ing regulation } \\
\text { forward }\end{array}$} & $\begin{array}{l}\text { Criminal } \\
\text { DNA } \\
\text { databases }\end{array}$ & $\begin{array}{l}\text { UK } \\
\text { Nether- } \\
\text { lands } \\
\text { France }\end{array}$ & $\begin{array}{l}\text { Expand uses } \\
\text { of DNA data- } \\
\text { base } \\
\text { Reduced costs } \\
\text { Counter- } \\
\text { balance } \\
\text { decrease in } \\
\text { size }\end{array}$ & $\begin{array}{l}\text { Non-con- } \\
\text { sented } \\
\text { extended } \\
\text { uses of } \\
\text { genetic } \\
\text { data }\end{array}$ \\
\hline & & $\begin{array}{l}\text { Mass } \\
\text { screenings }\end{array}$ & Germany & $\begin{array}{l}\text { Problematic } \\
\text { notion of } \\
\text { "voluntary" } \\
\text { participation }\end{array}$ & $\begin{array}{l}\text { Con- } \\
\text { sented } \\
\text { extended } \\
\text { uses of } \\
\text { genetic } \\
\text { data }\end{array}$ \\
\hline $\begin{array}{l}\text { Regulatory } \\
\text { Lag }\end{array}$ & $\begin{array}{l}\text { Outdated laws } \\
\text { Waiting for } \\
\text { incorporation } \\
\text { in legislation }\end{array}$ & $\begin{array}{l}\text { Non- } \\
\text { specified }\end{array}$ & $\begin{array}{l}\text { Other } \\
\text { European } \\
\text { countries }\end{array}$ & \multicolumn{2}{|c|}{ "Surveillance arbitration" } \\
\hline
\end{tabular}

Source: Authors. 
activities accordingly with scarce guidance. In view of this, existence of criminal high-profile criminal cases are frequently mobilized as outlets for "building-up" the uses of controversial technologies such as familial searching. Regardless of each country's legislative framework, the forensic geneticists interviewed showed awareness of the need for an ethical debate over the risks and benefits of using familial searching, as we will explain in the next section of this chapter.

\section{Politics of legitimation}

Forensic geneticists interviewed in this study believe that an ethical deliberation over familial searching is largely missing in most countries. Participants consider that familial searching should be framed as part of a responsible and accountable innovation framework which considers this technology's potential applications, utility and risks. In an area framed by complex politics of legitimation and contestation (Granja \& Machado, 2020; Skinner, 2018), forensic geneticists call for the need to address at least some aspects of what social scientist Matthias Wienroth calls the "RULE" framework: Reliability, Utility and LEgitimacy (Wienroth, 2020). As the following quotation shows, according to participants in this study, an ethically grounded debate over familial searching would ideally entail a comprehensive analysis of the utility of this technology, by reflecting upon its limitations and effective uses.

So, I do not see anyone discussing the pros and cons of familial searching; as far as I know the [law] only states that familial searching cannot be done, and that's it. So, this should be discussed and we should also look at where this is done. See whether it is successful or not and make a comprehensive evaluation, including the ethical aspects. (...) But in general, I think [country] should allow this [technique] with certain rules, evaluating the pros and cons and seeing if it works.

(Interview O09)

Besides considering the utility of familial searching, participants also reflect upon issues of social legitimacy. One of the main issues mentioned by interviewees regarding an ethical debate about familial searching, concerns the crimes for which the use of this investigative technique should be considered legitimate. Therefore, interviewees reflect upon the criteria that constitute good practice/use (Wienroth, 2020). In this regard, forensic geneticists usually defend the selective use of familial searching. Thus, most interviewees agree that this technology should be restricted to serious criminal cases with a high social impact. Framing familial searching as a technology that might provide useful contribution when all other means have failed, forensic geneticists therefore justify the infringement of the right to genetic privacy with its potentially positive social implications: solving serious criminal cases that have caused serious harm to society, using means that uphold public security and social justice. 
I think it should also be restricted. I think familial searching is very challenging. (...) When the case has high impact, everything should be done. With collegial decisions, because it directly violates some other basic rights over your own data of your genetic data as well. It should be a very restricted use, I think.

(Interview O06)

And I can understand that there may be very severe crimes where you would like to use that method. But then there should be very clear rules in place to rule on what is ethically acceptable or defensible in the use of that method.

(Interview O01)

One other significant topic discussed by participants in this study has to do with deciding the dataset that should be used to conduct familial searches, a topic which refers to issues of reliability. For criminal investigation purposes, there are two main options: conducting familial searching in pre-established forensic DNA databases and/or arrange a mass screening to conduct familial searching. While reflecting upon these options, some interviewees argued that familial searching should be mainly used in forensic DNA databases as it increases its usefulness, with reduced extra costs.

If you do this [familial search] in a database search, fair enough, because basically it does not cost you extra. If you do this in a mass screening there is a problem, because it does [emphasis] cost extra. And the idea that the perpetrator participates in such a dragnet, at least the probability, is small.

(Interview A02)

Some interviewees actually believe that familial searches are a useful tool to counterweigh decisions that have limited the range of DNA databases substantially. In this regard, we should recall the "S. and Marper" case (Amankwaa \& McCartney, 2018), which led to a decision by the European Court of Human Rights to destroy the samples of non-convicted persons in the NDNAD. Such decision led to the implementation of the Protections of Freedoms Act 2012 (PoFA) in the UK. Since PoFA was implemented, over 1.7 million forensic DNA profiles from innocent individuals have been deleted, and over 7.7 million DNA samples have been destroyed (Amankwaa \& McCartney, 2018, p. 119). According to the following participant, the use of familial searches in the UK's NDNAD is able to counteract the shrinking of the database:

From an ethical point view, I am in favour of familial searching, because it makes the database more efficient and useful in more cases. (...) But also, I think it has been a response to the fact that in the UK the number 
of database profiles has decreased, so you have to do it; the police are looking for ways to increase the usefulness of the database with less entries. So, you know, if a sibling is eliminated from a database, because they have not actually been convicted of a crime, they can still be identified in the familial search, it recovers some of that usefulness, if you understand what I mean.

(Interview C04)

The other dataset that can be used to conduct familial searches are mass screenings. According to some interviewees, this option is preferable, as it ensures that all participants are aware that their DNA can be used to identify biological relatives. That is, in the case of familial searches conducted in forensic DNA databases, informed consent about the intended and future uses of the contributed DNA is somehow blurred (did donors willingly consent to the use of their biological materials to prosecute their family members criminally?) (Granja \& Machado, 2019). In the case of mass screenings, participating individuals tend to provide samples "voluntarily" and are fully aware of its potential uses and implications, not only for them but also for relatives.

In many other countries, they use it for database searches. Here, they use it only for mass screening and at least the law states that all people participating should know it is not only used to check them (...) [it might also] have implications for their any nearest relatives. So, it's very important that people are aware about this.

(Interview O08)

The participation is completely voluntary and people who participate must be educated about the possibility that a first degree relative may be involved.

(Interview O01)

This position, however, is not consensual among forensic geneticists. Other participants showed significant concerns over the alleged "voluntary" nature of mass screenings. Although mass screenings do not tend to be mandatory, whenever someone refuses to participate, there is a tendency to immediately perceive that person as a potential suspect. This kind of rationale, consequently, raises the question of knowing what constitutes voluntary participation (to a critical view of this see Duster, 2006).

The screening wasn't mandatory, but if you declined you had to provide a reason, which, in a certain way, can be considered coercive; and actually, around that time some bioethics groups claimed "Look, the screening doesn't look too voluntary." 
If you have a brother who is asked to give a voluntary sample and he says: "Actually no, I am not really comfortable with this," then he becomes immediately a suspect. So, there must be an ethical dimension to that. It is actually not voluntary at all.

(Interview D12)

Seeing as ethics is increasingly considered part of the "epistemic toolkit of science" (Bliss, 2012), participants reflect upon how familial searching, as a technological innovation, should incorporate values beyond scientific validation - namely, reliability, utility, and legitimacy (Wienroth, 2020) - by engaging with a transparent, accountable and inclusive public debate. The different viewpoints on the uses of familial searching, therefore, fit into what we call the "politics of legitimation" that are being shaped by various forms of discursive boundary-work, whereby the forensic geneticists construct legitimate uses of this technology potential applications, its utility and risks. This ethical deliberation follows a line of reasoning that we have also encountered in previous works, in which we invited members of the forensic geneticists based in Europe to tell us about their views about another controversial genetic technology: forensic DNA phenotyping (Granja \& Machado, 2020, see also Chapter 6 in this volume).

\section{Civil identification: bringing historical reparation}

There are two apparently conflicting perspectives forensic geneticists' perception of familial searching. The first of these, explored in the previous section of this chapter and more commonly found in Central and Northern European countries, focuses on familial searching's uses to identify criminal suspects, consequently expanding suspicion. Another approach considers the uses of familial searching to support scientific and technological initiatives directed at identifying "missing persons," a term which, rather than focus on the causes of death, is becoming increasingly employed to refer the dead, the disappeared, the murdered, or even the "martyred," in a way that renders the different histories and, consequently, their variable political implications, invisible (Smith, 2017, p. 399). Within this framework of civil identification, DNA tends to be framed by a humanitarian rationale (Scully, 2014), which is perceived as having mostly positive outcomes.

Within the present study, discourses that point to civil identification have shown to be more common in countries with a recent history of repression by totalitarian regimes, as in the case of some Eastern and Southern European countries. In this regard, Poland - a country historically affected by the phenomenon of disappearance among its population (Colls, 2016) - is particularly relevant, having promoted several programs to identify "the missing." Among these, we find two examples that are particularly noteworthy. The first of these involves the GeNN consortium, ${ }^{3}$ established between ITAKA Foundation - Center for Missing Persons, Warsaw's Central Forensic Laboratory 
and Agencja Interaktywna Esencja Studio. The consortium aims to search for long-term missing persons and to identify unidentified buried bodies. Profiles of missing persons are obtained through the genetic material provided by the families of persons who disappeared before the January 1, 2004 and inserted into the catalogue of the National DNA Database for missing persons.

The other program involves the Polish Genetic Database for the Victims of Totalitarianism (www.pbgot.pl), created in 2012 and supported by the Pomeranian Medical University in Szczecin and the Institute of National Remembrance - Commission for the Prosecution of Crimes against the Polish Nation. The aim of this database is to identify the remains of unidentified victims of Communist and Nazi totalitarian regimes. This is an autonomous database (not connected to the Polish forensic DNA database) containing genetic information on material collected during exhumations, genetic information from relatives of victims of totalitarian regimes and historical and archaeological data (Ossowski et al., 2016).

Poland, however, is not the only case evincing concerted efforts to identify the missing. Other Eastern European countries equally affected by the disappearance of citizens (Pexa et al., 2018), also recurrently use familial searching for purposes of civil identification. As the following interviewee explains, indeed, this technology is much more frequently employed in the field of civil identification than in criminal investigations:

If [familial searching] is useful to solve any crimes, we have no restriction for this. (...) For missing persons, we do this very often. (...) Not for crimes because it is one - I already told you - information which I would not like to say to an investigator, because the amount of work will increase. So that is it.

(Interview L02)

The kinds of programs that search and identify "the missing" are usually perceived by most participants as having mostly positive outcomes. According to the majority of our interviewees, the identification of missing persons allows to (re)connect persons and bodies with their social relationships and identities (Schwartz-Marín \& Cruz-Santiago, 2017) thus bringing families' liminality of uncertainty to a close (Haimes \& Toom, 2014). Such positive outcomes are outlined by several interviewees, as the following quotation from a forensic expert directly involved with cases of missing persons illustrates:

And it is also very important for us that families looking for relatives will have the answer to their question, since for many years they have lived without information about their relatives.

(Interview G01)

Besides Eastern European countries, we find another group of countries where the potential uses of familial searching for civil identification purposes 


\section{Genetic Surveillance and Crime Control}

is frequently mentioned as a means to compensate families that have suffered traumatic losses in the past. A case in point is that of soldiers who went missing in action in wars instigated by dictatorial regimes in southern European countries with their African colonies, as highlighted in the following interview quotation:

Returning a body to the family, contributing to discover what happened to that person at the time of his/her death, how he/she died, etc.; all of that is very important because there is a feedback, I mean, there is reparation; a social benefit (...) Portuguese military had died 40 years ago and their families were still waiting, right? So, mourning can only take place when the body is found $[. .$.

(Interview N05)

Thus, confidence in the power of DNA to reveal the identities of the dead offers a path towards resolving serious national concerns and assuaging complex sociohistorical problems, by identifying misidentified corpses, fulfilling relatives' "right to know" (Garibian, 2014) and also bringing responsible actors to justice, as outlined by the following interviewee:

We can actually contribute to change things, and it can also lead to incriminate those responsible, right? People who committed murders, etc., in the domain of crimes against humanity. In cases of crimes against humanity there is also the intention to take those responsible to trial and that is important.

(Interview N05)

DNA-led approaches to the identification of missing people is, therefore, perceived as a use of science that serves the public good and contributes toward establishing a democratic and accountable state, while helping overcome historical traumas by providing closure to victims of past totalitarian political regimes (Granja \& Machado, 2019). These kinds of programs show how the concept of re(con)stitution, proposed by Lindsay Adams Smith in the context of human-rights forensics in post-conflict Argentina, also applies to other contexts. $\operatorname{Re}(\mathrm{con})$ stitution outlines how "the individual restitution of identity is tied to national constitutions of democratic transition" (Smith, 2016, p. 1040). Therefore, in such contexts, DNA identification functions as a political mechanism for building post-conflict and post-dictatorship democracies (Smith, 2016).

\section{Between control and care}

As explained in the course of this chapter, across Northern and Central European countries, familial searching is repeatedly associated with criminal justice efforts and often criticized as part of an expanding system of genetic 
surveillance. In Eastern and Southern Europe, familial searching is recurrently mentioned in connection with DNA-led identification of missing persons and, therefore, interpreted as a tool for guaranteeing human rights and re(cons)tituting democracy (Smith, 2017). The interviews we have conducted across Europe corroborated such trends very clearly. Nonetheless, it also becomes clear that rationales, which at first sight might be considered conflicting, namely controlling offenders and caring for the missing, are becoming increasingly embedded in shared infrastructures of control.

Substantial body of literature has described how the control of mobility across borders - whether directed at migration control and/or law enforcement - has contributed to justify, implement, and normalize complex database infrastructures and increase transnational police and judicial collaboration within Europe (Aas, 2006, 2013; Amelung et al., 2020). Two prominent examples of how DNA-led identification has been used in migration control pertain to the use of ancestry tests to determine the nationality of migrants (Abel, 2018; Tutton, Hauskeller, \& Sturdy, 2014) and the use of genetic material as a source of evidence in family reunification claims (Heinemann et al., 2015). However, less attention is paid to how "the missing" have been justifying a parallel and less visible emerging security - and disaster - focused identification grounded in global law enforcement (Smith, 2017). This trend is especially important, not only because it opens another avenue for expanding genetic surveillance, but also because it does so based on a humanitarian rationale. As observed by Nina Amelung, Rafaela Granja and Helena Machado (2020, p. 24) "the dominant policy narrative argues that this merging facilitates police cooperation on missing and unwanted persons as well as border control cooperation regarding the mobility of migrants in irregular situations" [italics added].

With the aim of enforcing transnational cooperation, the architecture of resources, policies, funding and experts increasingly merges efforts to identify missing persons with a security-focused forensic genetics (Smith, 2017). Transnational mechanisms of data exchange, such as Prüm, stand out in this context. Prüm is a pan-European system for reciprocal automated searching and comparison of DNA profile information (as well as fingerprints and vehicle registration data) intended to bolster cross-border cooperation, particularly in the fight against terrorism and cross-border crime (see Chapter 3).

Within Prüm, DNA files exchanged across countries cover a wide range of data categories, including convicted persons, suspects, crime stains, victims, unidentified persons, unidentified human remains, missing persons, relatives of missing persons, and others (Amelung et al., 2020).

As shown in Table 5.3, 14 countries exchange data from missing persons (EU Council, 2021): Austria, Belgium, Croatia, Czech Republic, Denmark, Estonia, Italy, Latvia, Malta, the Netherlands, Poland, Romania, Slovakia, and Slovenia. In addition, Malta exchanges data from relatives of missing persons. This trend has been gaining momentum over the years, as can be seen by the number of countries that have started to exchange this kind of data since the system first became operational. In addition to missing persons 
114 Genetic Surveillance and Crime Control

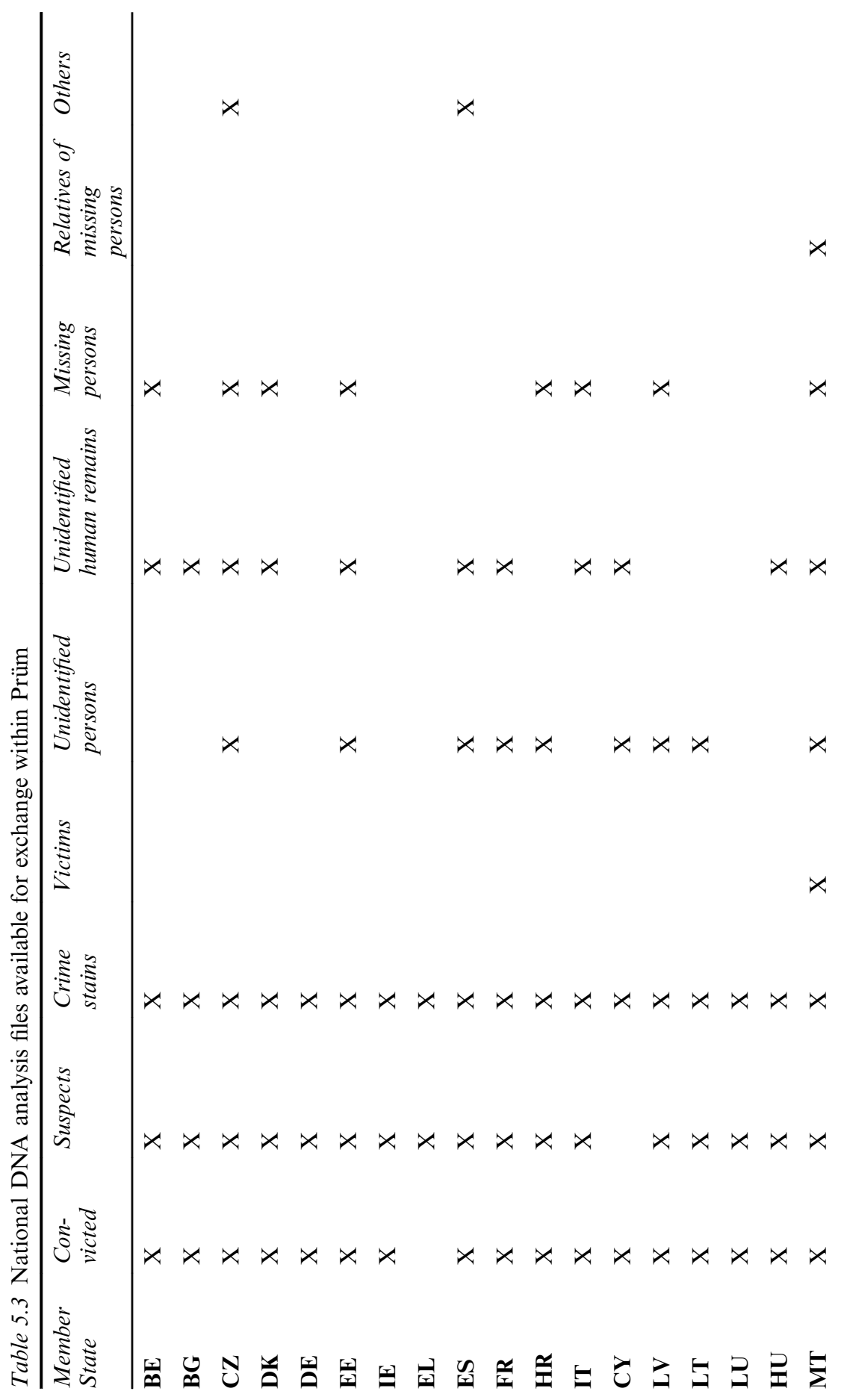


The Uses of Familial Searching in Europe 115

$$
\begin{aligned}
& x \times x \times x \\
& x \times x \times x \\
& x \times x \quad x \\
& x \times x \times x \times x \times x \\
& x \times x \times x \times x \\
& x \times x \times x \times x
\end{aligned}
$$

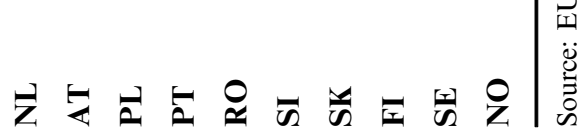


and their relatives, countries are also actively exchanging data regarding unidentified persons (exchanged by 14 countries) and unidentified human remains (exchanged by 18 countries) - see Table 5.3.

Therefore, it is clear that there has been a push to embed the scope of national missing persons' search and identification systems within an international framework, anchored in transnational collaboration and based on a criminal justice model. Such a move, mostly invisible but nonetheless powerful, has been legitimized by three main factors: first, since the scientific processes are identical, there is an inclination to treat different situations independently of their broader context (Smith, 2017); second, the state-of-theart resources available for credible identification as well as their infrastructures are already in place for criminal investigation and could be equally used use for civil identification purposes; third, a closer link between criminal investigation and civil identification facilitated by alliances with the international community, with global reach.

As outlined by Lindsay Adams Smith "It [is] not the similarity of experience that bound these various missing together, but the power of a scientific tool for rendering them identified" (Smith, 2017). Different uses of DNAidentification, namely control and care are, therefore, being amalgamated into a single political project aimed at expanding genetic surveillance. The implications of the interchange between control and care are two-fold: first, it allows to mitigate ethical concerns related to the expansion of complex architectures of control (Hufnagel \& McCartney, 2017; Machado \& Granja, 2018; McCartney, 2014; Prainsack \& Toom, 2010, 2013; Toom, Granja, \& Ludwig, 2019), now re-legitimized under the care rationale. Second, as global security increasingly becomes the main basis for DNA-identification projects, initiatives based upon human rights lose their foothold and are refocused on antiterrorism and individual crime (Smith, 2017).

\section{Conclusion}

Throughout this chapter we have shown how familial searching creates opportunities for "processes of restitution [that can] sit alongside those of discipline and control" (M'charek \& Wade, 2020, p. 324). We explored the discourses of forensic geneticists that revealed how social processes and ethical controversies are situated at the intersection of two distinct but still related rationales: expanding suspicion, by assisting criminal investigations and providing historical reparation and healing of collective trauma through support for programmes focused on the identification of missing persons.

When referring to the use of familial searching to identify criminal suspects, forensic geneticists usually point out the infringement of genetic privacy, its discriminatory potential, as well as familial searching' logistical challenges. Our analysis also shows that the heterogeneous scenario across Europe in terms of regulation, not only stems from different understandings of the ethical issues posed by familial searching but is also influenced by each 
country's tradition in terms of technoscientific innovation and, even more importantly, by the occurrence (or absence) of a high-profile criminal case that can be construed as a public drama and mobilized as an outlet to demonstrate the potential of this technology. Thereby, familial searching, finds itself in a "liminal space" (Knorr-Cetina, 1999), that is, a transitional and transformative state in which "the values and the norms of one stage have been left behind and the values and the norms of the later stage have not yet been reached" (Derksen, 2010). This implies that while some countries, such as the UK, the Netherlands, France, and Germany, have already produced legislation contemplating the specificities of this technology, others remain in a regulatory lag which opens the door to "surveillance arbitration" (Fussey \& Sandhu, 2020). That is, a situation in which practitioners must decide in each case whether or not to use familial searching. Nonetheless, forensic geneticists clearly see the need to engage familial searching within a framework of responsible research and innovation regardless of each country's regulatory situation, calling for an ethically informed debate centred around notions of reliability, utility, and legitimacy (Wienroth, 2020). As a result, interviewees' responses reflect their positions and views about the on-going complex politics of legitimation that frame the use of familial searching in the criminal justice system.

A small group of forensic geneticists, mostly based in Eastern and Southern European countries dealing with a recent legacy of authoritarian regimes, also refer to the uses of familial searching for purposes of civil identification. Following this rationale, technology is framed as a positive endeavour, able to provide historical reparation and heal collective traumas through the biology of victims (Haimes \& Toom, 2014; Schwartz-Marín \& Cruz-Santiago, 2017; Smith, 2016). Familial searching is, therefore, interpreted as a re(con)stitution-facilitating instrument (Smith, 2016).

As this framework of humanitarian DNA identification, focused on identifying victims of totalitarian and post-conflict regimes, becomes increasingly embedded in DNA-led identification efforts, we witness the consolidation of a type of depoliticized and scientifically grounded work being used universally in cases of natural disasters, migration, domestic crime, extra-state violence and terrorism (Smith, 2017). This sheds light on how the potential of familial searching to transition between criminal investigation purposes and civil identification efforts signals a subtle but still powerful shift from human-rights forensics towards emerging security and disaster-focused identification, grounded in global law enforcement (Smith, 2017). Such a trend is clearly demonstrated by the established architectures of crime control, such as Prüm system, which increasingly incorporates and exchanges data related to the missing in ways that mitigate concerns over the indiscriminate expansion of genetic surveillance.

\section{Notes}

1 https://www.telegraph.co.uk/news/uknews/1524209/Shoe-Rapist-kept-store-ofstilettos-as-trophies.html (last access November 12, 2020). 


\section{Genetic Surveillance and Crime Control}

2 Invalid matches that, if followed, might lead to miscarriages of justice.

3 www.projektgenn.pl/o-nas.

\section{References}

Aas, K.F. (2006). "The body does not lie": identity, risk and trust in technoculture. Crime, Media, Culture, 2(2), 143-158. https://doi.org/10.1177/1741659006065401.

Aas, K.F. (2013). Globalization and Crime (2nd ed.). Thousand Oaks: SAGE Publications.

Abel, S. (2018). What DNA can't tell: problems with using genetic tests to determine the nationality of migrants. Anthropology Today, 34(6), 3-6. https://doi.org/10.1111/ 1467-8322.12470.

Amankwaa, A.O. \& McCartney, C. (2018). The UK national DNA database: implementation of the Protection of Freedoms Act 2012. Forensic Science International, 284, 117-128. https://doi.org/10.1016/j.forsciint.2017.12.041.

Amelung, N., Granja, R., \& Machado, H. (2020). Modes of Bio-bordering: The Hidden (Dis) integration of Europe (1st ed.). London: Palgrave Macmillan. https:// doi.org/10.1007/978-981-15-8183-0.

Bieber, F.R., Brenner, C.H., \& Lazer, D. (2006). Finding criminals through DNA of their relatives. Human Genetics, 312(5778), 1315-1316. https://doi.org/10.1126/sci ence.1122655.

Biometrics and Forensics Ethics Group. (2020). Should we be making use of genetic genealogy to assist in solving crime? A report on the feasibility of such methods in the $U K$ (Issue September). Biometrics and Forensic Ethics Group, United Kingdom.

Bliss, C. (2012). Race Decoded: The Genomic Fight For Social Justice. Redwood City: Stanford University Press.

Chamberlain, M. (2012). Familial DNA searching. A proponent's perspective. Criminal Justice, 27(1), 18-30. www.americanbar.org/content/dam/aba/publications/crim inal_justice_magazine/sp12_dna_search_proponents.authcheckdam.pdf.

Cole, S. (2007a). Coming clean about "junk DNA." Northwestern University Law Review Colloquy, 102, 107-109.

Cole, S. (2007b). Is the "junk" DNA designation bunk? Northwestern University Law Review Colloquy, 102, 54-63.

Cole, S. (2009). Forensics without uniqueness, conclusions without individualization: the new epistemology of forensic identification. Law, Probability and Risk, 8(3), 233-255. https://doi.org/10.1093/lpr/mgp016.

Colls, C.S. (2016). 'Earth Conceal Not My Blood': Forensic and Archaeological Approaches to Locating the Remains of Holocaust Victims. In J.-M. Dreyfus \& É. Anstett (Eds), Human Remains in Society: Curation and Exhibition in the Aftermath of Genocide and Mass-violence (163-196). Manchester: Manchester University Press.

Debus-Sherrill, S. \& Field, M.B. (2019). Familial DNA searching- an emerging forensic investigative tool. Science \& Justice, 59(1), 20-28. https://doi.org/10.1016/j. scijus.2018.07.006.

Derksen, L. (2010). Micro/macro translations: the production of new social structures in the case of DNA profiling. Sociological Inquiry, 80(2), 214-240. https://doi.org/ 10.1111/j.1475-682X.2010.00328.x.

Dettlaff-Kakol, A. \& Pawlowski, R. (2002). First polish DNA “manhunt"- an application of Y-chromosome STRs. International Journal of Legal Medicine, 116(5), 289-291. https://doi.org/10.1007/s00414-002-0320-0. 
Duster, T. (2006). Explaining differential trust of DNA forensic technology: grounded assessment or inexplicable paranoia? Journal of Law, Medicine \& Ethics, 34(2), 293-300. https://doi.org/10.1111/j.1748-720X.2006.00034.x.

EU Council. (2021). Implementation of the provisions on information exchange of the "Prüm Decisions". Official Journal of the European Union. Brussels.

Flaus, A. (2013). Familial Searches and the New Zealand DNA Profile Databank: The Thin Edge of the Genetic Wedge? [Dissertation of the degree of Bachelor of Laws, University of Otago].

Fussey, P. \& Sandhu, A. (2020). Surveillance arbitration in the era of digital policing. Theoretical Criminology, 1-20. https://doi.org/10.1177/1362480620967020.

Gabel, J.D. (2010). Probable cause from probable bonds: a genetic tattle tale based on familial DNA. Hastings Women's Law Journal, 21(3), 3-58. http://ssrn.com/abstra $\mathrm{ct}=1495128$.

Gandsman, A. (2012). The limits of kinship mobilizations and the (a)politics of human rights in Argentina. Journal of Latin American and Caribbean Anthropology, 17(2), 193-214. https://doi.org/10.1111/j.1935-4940.2012.01219.x.

García, Ó., Crespillo, M., \& Yurrebaso, I. (2017). Suspects identification through "familial searching" in DNA databases of criminal interest. Social, ethical and scientific implications. Spanish Journal of Legal Medicine, 43(1), 26-34. https://doi.org/ 10.1016/j.remle.2017.02.002.

Garibian, S. (2014). Ghosts also die: resisting disappearance through the 'right to the truth' and the juicios por la verdad in Argentina. Journal of International Criminal Justice, 12(3), 515-538. https://doi.org/10.1093/jicj/mqu030.

Granja, R. \& Machado, H. (2019). Ethical controversies of familial searching: the views of stakeholders in the United Kingdom and in Poland. Science, Technology, \& Human Values, 44(6), 1068-1092. https://doi.org/10.1177/0162243919828219.

Granja, R. \& Machado, H. (2020). Forensic DNA phenotyping and its politics of legitimation and contestation: views of forensic geneticists in Europe. Social Studies of Science, 1-19. https://doi.org/10.1177/0306312720945033.

Greely, H.T., Riordan, D.P., Garrison, N.A., \& Mountain, J.L. (2006). Family ties: the use of DNA offender databases to catch offenders' kin. The Journal of Law, Medicine \& Ethics, 34(2), 248-262. https://doi.org/10.1111/j.1748-720X.2006.00031.x.

Haimes, E. (2006). Social and ethical issues in the use of familial searching in forensic investigations: insights from family and kinship studies. The Journal of Law, Medicine \& Ethics, 34(2), 263-276. https://doi.org/10.1111/j.1748-720X.2006.00032.x.

Haimes, E. \& Toom, V. (2014). Hidden in full sight: kinship, science and the law in the aftermath of the Srebrenica genocide. New Genetics and Society, 33(3), 277-294. https://doi.org/10.1080/14636778.2014.946004.

Heinemann, T., Helén, I., Lemke, T., Naue, U., \& Weiss, M.G. (Eds). (2015). Suspect Families: DNA Analysis, Family Reunification and Immigration Policies. London: Routledge.

Hindmarsh, R. \& Prainsack, B. (Eds). (2010). Genetic Suspects: Global Governance of Forensic DNA Profiling and Databasing. Cambridge: Cambridge University Press.

Hufnagel, S. \& McCartney, C. (Eds). (2017). Trust in International Police and Justice Cooperation. Oxford: Hart Publishing. http://dx.doi.org/10.5040/9781782257868.

Jones, T. (2015, January 8). The murder that has obsessed Italy. The Guardian. https:// www.theguardian.com/world/2015/jan/08/-sp-the-murder-that-has-obsessed-italy. 
Kim, J., Mammo, D., Siegel, M.B., \& Katsanis, S.H. (2011). Policy implications for familial searching. Investigative Genetics, 2(22), 1-9. https://doi.org/10.1186/ 2041-2223-2-22.

Knorr-Cetina, K. (1999). Epistemic Cultures. How the Sciences Make Knowledge. Cambridge: Harvard University Press.

Kruijver, M.V. (2016). Stochastic aspects of familial searching [Doctoral Dissertation, University of Amsterdam].

Lee, J. (2016). The presence and future of the use of DNA-information and the protection of genetic informational privacy: a comparative perspective. International Journal of Law, Crime and Justice, 44, 212-229. https://doi.org/10.1016/j.ijlcj.2015.10.001.

M'charek, A., Toom, V., \& Jong, L. (2020). The trouble with race in forensic identification. Science, Technology, \& Human Values, 45(5), 804-828. https://doi.org/10. $1177 / 0162243919899467$.

M'charek, A. \& Wade, P. (2020). Doing the individual and the collective in forensic genetics: governance, race and restitution. BioSocieties, 15(3), 317-328. https://doi. org/10.1057/s41292-020-00193-6.

Machado, H. \& Granja, R. (2018). Ethics in transnational forensic DNA data exchange in the EU: constructing boundaries and managing controversies. Science as Culture, 27(2), 242-264. https://doi.org/10.1080/09505431.2018.1425385.

Machado, H. \& Granja, R. (2020). Forensic Genetics in the Governance of Crime. Singapore: Springer Singapore. https://doi.org/10.1007/978-981-15-2429-5.

Machado, H. \& Santos, F. (2009). The disappearance of Madeleine McCann: public drama and trial by media in the portuguese press. Crime, Media, Culture, 5(2), 146167. https://doi.org/10.1177/1741659009335691.

Maguire, C.N., McCallum, L.A., Storey, C., \& Whitaker, J.P. (2014). Familial searching: a specialist forensic DNA profiling service utilising the national DNA database ${ }^{\circledR}$ to identify unknown offenders via their relatives - the UK experience. Forensic Science International: Genetics, 8(1), 1-9. https://doi.org/10.1016/j.fsigen. 2013.07.004.

McCartney, C. (2014). Transnational Exchange of Forensic Evidence. In G. Bruinsma \& D. Weisburd (Eds), Encyclopedia of Criminology and Criminal Justice (53025313). New York: Springer. https://doi.org/10.1007/978-1-4614-5690-2.

Moon, C. (2013). Interpreters of the dead: forensic knowledge, human remains and the politics of the past. Social \& Legal Studies, 22(2), 149-169. https://doi.org/10.1177/ 0964663912463724.

Murphy, E. (2010). Relative doubt: familial searches of DNA databases. Michigan Law Review, 109(3), 291-348.

Ossowski, A., Kuś, M., Kupiec, T., Bykowska, M., Zielińska, G., Jasiński, M.E., \& March, A.L. (2016). The polish genetic database of victims of totalitarianisms. Forensic Science International, 258, 41-49. https://doi.org/10.1016/j.forsciint.2015. 10.029 .

Pexa, T., Krajsa, J., Šaðková, M., Velemínský, P., Havrda, J., Kotrlý, T., \& Drábek, J. (2018). Identification of the skeletal remains of the Czech communist regime crime victim, priest Josef Toufar. Forensic Science International, 291, e13-e17. https://doi. org/10.1016/j.forsciint.2018.07.002.

Pham-Hoai, E., Crispino, F., \& Hampikian, G. (2014). The first successful use of a low stringency familial match in a french criminal investigation. Journal of Forensic Sciences, 59(3), 816-819. https://doi.org/10.1111/1556-4029.12372. 
Phillips, C., Brown, T., Schneider, P.M., Geddes, L., Syndercombe-Court, D., Gill, P., Thomas, J., Jésper-Mir, E., Wienroth, M., Kayser, M., \& Williams, R. (2017). Making sense of forensic genetics. Sense about Science. https://senseaboutscience.org/ wp-content/uploads/2017/01/making-sense-of-forensic-genetics.pdf.

Prainsack, B. (2010). Key Issues in DNA Profiling and Databasing: Implications for Governance. In R. Hindmarsh \& B. Prainsack (Eds), Genetic Suspects: Global Governance of Forensic DNA Profiling and Databasing (pp. 153-174). Cambridge: Cambridge University Press.

Prainsack, B. \& Toom, V. (2010). The Prüm regime. Situated dis/empowerment in transnational DNA profile exchange. British Journal of Criminology, 50(6), 11171135. https://doi.org/10.1093/bjc/azq055.

Prainsack, B. \& Toom, V. (2013). Performing the union: the Prüm decision and the European dream. Studies in History and Philosophy of Science Part C: Studies in History and Philosophy of Biological and Biomedical Sciences, 44(1), 71-79. https:// doi.org/10.1016/j.shpsc.2012.09.009.

Roewer, L. (2013). DNA fingerprinting in forensics: past, present, future. Investigative Genetics, 4(22), 1-10. https://doi.org/10.1186/2041-2223-4-22.

Rose, N. (2000). The biology of culpability: pathological identity and crime control in a biological culture. Theoretical Criminology, 4(1), 5-34. https://doi.org/10.1177/ 1362480600004001001.

Schwartz-Marín, E. \& Cruz-Santiago, A. (2017). Forensic civism: articulating science, DNA and kinship in contemporary Mexico and Colombia. Human Remains \& Violence, 2(1), 58-74. https://doi.org/10.7227/HRV.2.1.5.

Scully, J.L. (2014). Naming the dead: DNA-based identification of historical remains as an act of care. New Genetics and Society, 33(3), 313-332. https://doi.org/10.1080/ 14636778.2014.946002.

Simoncelli, T. (2006). Dangerous excursions: the case against expanding forensic DNA databases to innocent persons. The Journal of Law, Medicine \& Ethics, 34(2), 390397. https://doi.org/10.1111/j.1748-720X.2006.00045.x.

Skinner, D. (2006). Racialized futures: biologism and the changing politics of identity. Social Studies of Science, 36(3), 459-488. https://doi.org/10.1177/ 0306312706054859.

Skinner, D. (2013). "The NDNAD has no ability in itself to be discriminatory": ethnicity and the governance of the UK national DNA database. Sociology, 47(5), 976-992. https://doi.org/10.1177/0038038513493539.

Skinner, D. (2018). Race, racism and identification in the era of technosecurity. Science as Culture, 29(1), 77-99. https://doi.org/10.1080/09505431.2018.1523887.

Smith, L.A. (2016). Identifying democracy: citizenship, DNA, and identity in postdictatorship Argentina. Science, Technology, \& Human Values, 41(6), 1037-1062. https://doi.org/10.1177/0162243916658708.

Smith, L.A. (2017). The missing, the martyred and the disappeared: global networks, technical intensification and the end of human rights genetics. Social Studies of Science, 47(3), 398-416. https://doi.org/10.1177/0306312716678489.

Suter, S.M. (2010). All in the family: privacy and DNA familial searching. Harvard Journal of Law \& Technology Volume, 23(2), 309-399. http://jolt.law.harvard.edu/a rticles/pdf/v23.2/23HarvJLTech309.pdf.

Thomas, L. (2006). Nothing to hide, something to fear?: the use of partial DNA matching in criminal investigations. Journal of Law, Information and Science, 17, $72-93$. 


\section{Genetic Surveillance and Crime Control}

Toom, V., Granja, R., \& Ludwig, A. (2019). The Prüm decisions as an aspirational regime: reviewing a decade of cross-border exchange and comparison of forensic DNA data. Forensic Science International: Genetics, 41, 50-57. https://doi.org/10. 1016/j.fsigen.2019.03.023.

Tutton, R., Hauskeller, C., \& Sturdy, S. (2014). Suspect technologies: forensic testing of asylum seekers at the UK border. Ethnic and Racial Studies, 37(5), 738-752. http s://doi.org/10.1080/01419870.2013.870667.

Wienroth, M. (2018). Governing anticipatory technology practices. Forensic DNA phenotyping and the forensic genetics community in Europe. New Genetics and Society, 37(2), 137-152. https://doi.org/10.1080/14636778.2018.1469975.

Wienroth, M. (2020). Value beyond scientific validity: let's RULE (Reliability, Utility, Legitimacy). Journal of Responsible Innovation, 7(Sup1), 92-103. https://doi.org/10. 1080/23299460.2020.1835152.

Williams, R. \& Johnson, P. (2006). Inclusiveness, effectiveness and intrusiveness: issues in the developing uses of DNA profiling in support of criminal investigations. Journal of Law, Medicine \& Ethics, 34(2), 234-247. https://doi.org/10.1111/j.1748-720X.2006. 00030.x.

Winter, H., \& Hoving, R.A., Veen, C., \& Boxum, C. (2019). Evaluatie regeling DNAverwantschapsonderzoek. Pro Facto. University of Groningen. http://hdl.handle.net/ 11370/adc0491b-cd0c-48eb-8126-d0d0ecabd04d. 


\section{Expanding Genetic Informativity Through Emerging Technologies \\ The Cases of Forensic DNA Phenotyping and Next Generation Sequencing}

\section{Introduction}

Innovations in the field of forensic genetics continuously seek to provide answers to practical and common exigencies of criminal investigations. In the early stages of DNA use as evidence in the courts (in the late 1980s), the most recurrent problem for scientists was to respond to concerns about the quality of laboratory processes and the reliability of sample collection, preservation, contamination processes, etc. (Lynch, 2013; Lynch et al., 2008; Lynch \& McNally, 2003). Another topic of dispute had to do with developing trusted standardization strategies for the estimation of the random match probabilities deemed relevant for reasoning about the significance of DNA matches in determining particular instances of fact (Amorim, 2012; Kruse, 2013). While these concerns are still voiced and controversies not yet fully resolved, in the 2000s, the ambitions of innovation in forensic genetics moved to a different level: to amplify the possibilities of genetic informativity by introducing direct or indirect analysis of DNA coding regions.

The exceptional richness of information in genetic data, and the idea of the distinctively informative potential of genetics, had a powerful impact on the creation of legislation regulating the use DNA technologies in the criminal justice system in different states around the world (Hindmarsh \& Prainsack, 2010). Much of the existing legislation on the collection and use of DNA in Europe emphasizes the restriction of forensic DNA to "non-coding" or "uninformative" regions of the human genome (Nuffield Council on Bioethics, 2007; Reed \& Syndercombe-Court, 2016). This "non-coding" region was considered to be only informative for distinguishing between two DNA donors and therefore commonly considered not to constitute a breach of privacy or sensitive information.

This chapter addresses two examples of emerging forensic genetic technologies that amplify the possibilities of genetic informativity and create frictions between non-coding and coding DNA, with important implications in genetic surveillance: forensic DNA phenotyping (FDP) and next generation sequencing (NGS). Another example of the expansion of genetic informativity as an

DOI: $10.4324 / 9780429261435-6$ 


\section{Genetic Surveillance and Crime Control}

aid to criminal investigation activities, which we will briefly discuss in the final section of this chapter, is found in long-range familial searches, conducted in recreational DNA databases to detect genetic relatedness with the purpose of identifying criminal suspects (Granja, 2020; Kennett, 2019; Murphy, 2018). The expansion of genetic informativity will inevitably lead to new paths for genetic surveillance, with an enhanced potential for increasing discrimination and stigmatization that might infringe human rights, fundamental freedoms or the human dignity of an individual, family, group or community. An overview of the aims, differences, and commonalities of FDP, NGS, and long-range familial search is summarized in Table 6.1.

Despite the ethical and legal controversies at stake, these technologies are attracting wide interest among scientists, commercial providers, and stakeholders of the criminal justice system (Granja \& Machado, 2020; Samuel \& Prainsack, 2019; Wienroth, 2020a). This chapter explores the expectations created around FDP and NGS and their application in the realm of criminal investigations among members of the European community of forensic geneticists. Studying the views conveyed by this professional group allows us to understand the ongoing transitions and transformations in the use of forensic genetics in the governance of crime (Machado \& Granja, 2020), providing relevant objects for a critical assessment to discern the robustness, reliability, and utility of these technologies in the present and future of criminal investigations. Our analysis is based on 47 qualitative interviews conducted with 49 forensic geneticists based in 14 different European countries.

Inspired by the analytical lens of the sociology of expectations, this chapter will address the following research questions: which promises and hopes,

Table 6.1 Technologies that expand genetic informativity

\begin{tabular}{|c|c|c|c|}
\hline Technology & Aims & Differences & Commonalities \\
\hline $\begin{array}{l}\text { Forensic DNA } \\
\text { phenotyping }\end{array}$ & $\begin{array}{l}\text { Infer externally } \\
\text { visible character- } \\
\text { istics } \\
\text { Infer biogeo- } \\
\text { graphical ancestry }\end{array}$ & $\begin{array}{l}\text { Directed at serious } \\
\text { crimes } \\
\text { Dependent upon } \\
\text { national regulation } \\
\text { (National character) }\end{array}$ & \multirow{3}{*}{$\begin{array}{l}\text { Further compound } \\
\text { the interrelation } \\
\text { between individual } \\
\text { and collective iden- } \\
\text { tification } \\
\text { Blurs boundaries } \\
\text { between coding and } \\
\text { non-coding DNA } \\
\text { Increasing relevant } \\
\text { role of forensic } \\
\text { industry and mar- } \\
\text { ketization of science } \\
\text { Move from forensic } \\
\text { genetics towards } \\
\text { forensic genomics }\end{array}$} \\
\hline $\begin{array}{l}\text { Next generation } \\
\text { sequencing }\end{array}$ & $\begin{array}{l}\text { Provide compre- } \\
\text { hensive analysis of } \\
\text { DNA }\end{array}$ & $\begin{array}{l}\text { Directed at complex } \\
\text { DNA profiles } \\
\text { Dependent upon } \\
\text { available resources in } \\
\text { laboratories (Local } \\
\text { character) }\end{array}$ & \\
\hline $\begin{array}{l}\text { Long-range } \\
\text { familial searches }\end{array}$ & $\begin{array}{l}\text { Detect genetic } \\
\text { relatedness to iden- } \\
\text { tify criminal } \\
\text { suspects }\end{array}$ & $\begin{array}{l}\text { Dependent upon reg- } \\
\text { ulation of recrea- } \\
\text { tional DNA database } \\
\text { companies (Transna- } \\
\text { tional character) }\end{array}$ & \\
\hline
\end{tabular}

Source: Authors. 
along with concerns and anxieties, over present and future capabilities are associated with FDP and NGS? How do the expectations created by FDP and NGS influence how forensic geneticists construct and perform the legitimacy of their expertise? How do they manage the tensions between opening up new opportunities for research in the field of forensic genetics and the uncertainties of their application to case work?

This chapter will show that expectations around innovations in the field of forensic genetics might profoundly change contemporary views about (diverging) principles of legitimacy (or lack thereof) regarding the use of genetic data in criminal investigation, while opening up new paths for defining the nature and limits of criminal identification, as well as to establish what the governance of forensic genetics should be allowed and willing to inspect. Some of the main findings and insights gained from this study might be taken up for comment and critique on future-oriented practices including scenarios and foresight (Brown \& Michael, 2003; Hedgecoe, 2010; Hedgecoe \& Martin, 2003; Wienroth, 2020b).

\section{Locating FDP and NGS in the broader trajectory of forensic genetics}

According to Matthias Wienroth and colleagues (2014), the scientific and technological innovations in forensic genetics might be framed within four waves: the first wave relates to establishing the robustness of DNA profiling and creating the legitimacy of its status as criminal evidence in court (Jasanoff, 1995; Lynch et al., 2008). The second wave concerns the establishment and development of national criminal DNA databases, and the creation of international standards and harmonization of procedures for internalization of DNA database and profile exchange (Hindmarsh \& Prainsack, 2010; Machado \& Granja, 2018; McCartney, Wilson \& Williams, 2011; Prainsack \& Toom, 2010, 2013). The third wave comprises the development and increasing application of technologies that go beyond individual identification (Wienroth, Morling \& Williams, 2014), namely familial searching (see Chapter 5) and FDP (Amelung, 2021; Amelung \& Machado, 2021; Granja \& Machado, 2019, 2020; Granja, Machado \& Queirós, 2020; Queirós, 2021; Samuel \& Prainsack, 2019; Wienroth, 2020a).

For the last two decades, research groups and commercial providers have been developing new analysis methods aimed at providing answers to more complex cases, in which traditional DNA profiling techniques do not offer a satisfactory solution. Typically, situations where a biological sample is found at a crime scene, but the criminal investigation cannot advance based on genetic information. Circumstances in which the biological traits found at the crime scene are not useful for locating potential criminal suspects occur, for example, in the absence of a match between the crime scene profile and the subject profiles contained in criminal DNA databases. Third wave technologies are designed to provide answers to these kinds of inconsistencies, and therefore are expected to help solve serious criminal cases that otherwise would run out of satisfactory leads to identify offenders. 
FDP began to be developed in the early 2000s (Kayser \& Schneider, 2009). It can be broadly described as a set of techniques that aim to infer externally visible physical features in humans - eye, hair, and skin color - and biogeographical ancestry of criminal suspects, through analysis of biological materials collected at crime scenes (Kayser, 2015; Kayser \& de Knijff, 2011). FDP's distinctive feature is that it does not aim to provide data capable of identifying unique individuals on a probabilistic basis, but instead points towards a collective dimension of suspicion (M'charek, 2008). FDP technologies have already been applied in different jurisdictions in a very limited number of high-profile cases (Wienroth, 2018). However, its regulation is subject to considerable controversies, as the German debate has so illustratively shown (Amelung, 2021; Amelung \& Machado, 2021). FDP use in criminal investigation is also still highly controversial, owing to persisting concerns about its robustness, reliability and potential for flawed interpretation of the probabilistic nature of its results (Granja et al., 2020; Granja \& Machado, 2020; Wienroth, 2020b). In addition, several authors have also expressed concerns that research in the field of FDP might be an attempt to lay a scientific foundation for racial categorization and that FDP's operational application might consolidate racial discrimination (M'charek, 2020; M'charek, Toom \& Jong, 2020; Queirós, 2021; Skinner, 2018). Scientists and stakeholders of the criminal justice system tend to declare that FDP is helpful informing police priorities and reducing a suspect pool (Samuel \& Prainsack, 2018b; Wienroth, 2018).

The fourth wave of innovation in forensic genetics, according to Matthias Wienroth and colleagues (2014), is marked by the arrival of NGS, which aims to provide a comprehensive DNA profile comprising short tandem repeat, single nucleotide polymorphisms (SNP), mitochondrial, and Y-chromosome DNA for forensic genetics. NGS is a term used to describe DNA sequencing technologies whereby multiple pieces of DNA are sequenced in parallel. NGS is also known as massive parallel sequencing or high throughput sequencing, and the terms are often used interchangeably. In this chapter, we will use the term NGS.

NGS has started to be developed in bioengineering and biomedicine in the late 1990s and equipment has been commercially available since 2005. Since the 2010s NGS has been attracting interest in the field of forensic genetics. However, its uses in this specific field are still at an exploratory phase, and no concrete application in case work is yet known. Forensic geneticists point out that recent technological developments made possible by NGS promise an outbreak of genetic data that will revolutionize forensic genetics (Amorim \& Pinto, 2018; Budowle, Schmedes \& Wendt, 2017; Yang, Xie \& Yan, 2014). The promised potential benefits to criminal investigation include increased speed, efficiency, sensitivity, and depth of information gathered from DNA (de Knijff, 2019; Scudder et al., 2018). Another expected advantage of NGS is its higher multiplexing capacity to combine different genetic markers, therefore allowing different types of DNA markers to be obtained in just one 
analysis. In addition, NGS is expected to help FDP analysis (among many other applications), as it might provide more informative DNA markers to ancestry prediction and biogeographic origin. Contrary to FDP - which, as mentioned earlier, does not aim to identify uniqueness - the NGS techniques promise to allow searching for "discernible uniqueness": for example, NGS techniques are considered to be a real breakthrough in distinguishing identical twins (Amorim \& Pinto, 2018).

The expansion of genetic informativity through emerging technologies such as FDP and NGS has profound implications for the relationship between "individual" and "collective" human identification. These are central ontological categories, although increasingly complicated to sustain in binary pairs. When individual identification is not possible, the interest of criminal investigation shifts to the collective ("population group," "race") in which an unknown suspect is deemed to belong (Cole, 2018; M'charek \& Wade, 2020). In the next section of this chapter, we will discuss how the mutually constitutive relation between the individual and the collective in human identification produced by forensic genetics has ethical and political implications on the genetic surveillance of criminal suspects.

\section{Expectations towards innovations in forensic genetics}

Social sciences studies have consistently showed that novel or emerging technologies do not substantively pre-exist themselves, except in the realm of the imagination; of expectations and visions that have shaped their potential. These dynamics have been explored from a theoretical and analytical perspective by the "sociology of expectations" (Brown \& Michael, 2003). Studies in this field show that expectations for new and emerging technologies tend to be future-oriented abstractions with "generative" power: they guide activities, provide structure and legitimation, attract interest and foster investment (Borup et al., 2006; Brown \& Michael, 2003; Konrad, 2006). More particularly, expectations play a central role in mobilizing resources both at a macro level (for example, national policy through funding) and at the meso level of sectors and innovations networks. Expectations also play an important role at micro-level within research groups and in the work of a single scientist (Borup et al., 2006, p. 286). In sum, expectations guide the activities of actors within a technological field, while, in turn, expectations will be shaped and reshaped by research results, findings, successful commercialization, and external trends and forces (van Merkerk \& Robinson, 2006).

Expectations are also "performative": they are wishful enactments of a desired future, and by performing such futures they are made real. As suggested by many works on the performative dimension of expectations in innovation processes (Brown \& Rappert, 2000; Hedgecoe \& Martin, 2003; Michael, 2000; Selin, 2008; Tutton, 2011), positive promises and hopes of future capabilities are accompanied by fears and concerns about future risks, although different in character and having different dynamics. Consequently, 
future-oriented visions can be either "hype" and "optimistic," or less optimistic, uncertain and accompanied by modest expectations. Both "high" and "low" expectations have a role in providing momentum to innovation projects and in encouraging innovation alliances (Gardner, Samuel \& Williams, 2015; Tutton, 2011).

With the advent of new forensic technologies, such as FDP (already in use, although so far applied only exceptionally in a limited number of jurisdictions in Europe) and with NGS on the horizon (not yet applied in criminal cases, as far as we know), forensic genetics is in a transitional state (Granja, 2020; Machado \& Granja, 2020). On the one hand, the work of forensic geneticists attempts to sustain widely disseminated notions of forensic genetics' symbolic power to solve criminal cases (Lynch et al., 2008), within a scenario marked by a techno-optimism (Quinlan, 2020) that encompasses public perceptions, the media, policy makers and forensic industry (Machado \& Silva, 2019; Podlas, 2006; Wienroth, 2020a). On the other hand, emerging technologies, such as FDP and NGS, require forensic geneticists to deal with a range of potentially controversial uses without much guidance (Wienroth, 2018) and to manage a constant negotiation between high expectations, fueled by promises and hopes, and low expectations (Fitzgerald, 2014; Pickersgill, 2011; Tutton, 2011) tainted by concerns and anxieties (Granja \& Machado, 2020).

\section{Forensic DNA phenotyping}

\section{Tensions between the individual and the collective}

Forensic geneticists who participated in this study presented FDP as a technology with the ability to mitigate what has thus far been considered one of DNA profiling and databasing's greatest limitations: its comparative character. For instance, whenever no matches are found between a crime scene sample and a certain suspect and/or between a crime scene sample and a DNA database search, forensic genetics have been unable to advance criminal investigations, as explained by the following interviewee:

One of the biggest problems in the practice of forensic genetics is that you can only identify someone you know, because you have to have their DNA profile; because DNA profiling in the standard way is completely comparative. If you have a nice DNA profile from the crime scene but you do not already know the profile you have no match, it leads you nowhere.

(Interview A02)

Thus, interviewees present FDP as a solution to this forensic science's selfdiagnosis. By enabling to infer characteristics from a crime sample, FDP can "generate" a group of suspects when no other leads are available (M'charek, 2008). Forensic geneticists interviewed for this study describe FDP as a 
pivotal moment in forensic genetic technologies in the criminal justice system, since it shifts the focus of forensic science from the construction of evidence to the generation of intelligence valuable for criminal investigations: "It may help the police steer their investigations" (Interview D09).

However, the discourses of forensic experts also make clear that the possibilities opened up by FDP do not eliminate the need to establish, at a later stage of the criminal investigation, a direct comparison between a crime scene profile and a given suspect in order to confirm that both correspond to the same individual. This requirement follows from the permanent tension between the individual and the collective on which FDP stands. As outlined by the following interviewee, FDP should be understood as a two-step procedure: first it implies inferring the suspect group (that is, a collective dimension of suspicion) through the production of intelligence about probable features and then the confirmation of the individual suspect (that is, an individual dimension of suspicion) by conducting a traditional DNA comparison between the crime scene sample and the given suspect.

You first want to find your person of interest, for example, say "well, he looks like this," and then if you are lucky, you find someone who resembles to this person. Also, you have other pieces of evidence, and if you then have a person of interest or a suspect, you can get the DNA from this person so as to compare it again by the usual DNA profiling procedure. And finally you can be certain whether or not it is the person of interest.

(Interview O08)

By making an inference about the population group(s) which the alleged suspect belongs to, FDP is portrayed by forensic geneticists in this study as a technology that produces information which can guide the criminal investigation in a certain direction, thereby reducing the potential pool of suspects, and becoming an investigative, rather than probative, technology.

We always need to make sure that people understand that this method is suitable to reduce the possible number of people who could have made or placed this stain. But the actual identification of the donor of the stain needs to be done by conventional DNA analysis. So it also means that ultimately, what will be discussed in court is the final conventional DNA analysis rather than the so-called extended DNA analysis.

(Interview 013)

Generally speaking, FDP will never be introduced in trial, I cannot see that it would come to court.

(Interview D09)

The shift from the construction of evidence to the production of intelligence arouses other resistances. An example is the tension caused in the pre- 
established division between coding and non-coding DNA, which several European countries used as a baseline to create and implement forensic DNA legislation. The challenges posed by the expansion genetic informativity to the distinction between non-coding and coding regions of DNA is precisely a characteristic of the third (and fourth) waves of innovation in forensic genetics (Cole, 2018; Dimeglio et al., 2018; Reed \& Syndercombe-Court, 2016; Wienroth et al., 2014). FDP tends to use SNPs, rather than STRs. Unlike STRs, that presumably hold little value other than identification (Cole, 2007), SNPs are characterized by informational richness. In the case of FDP, SNPs allow enrolling appearance and race in the field of forensic genetics (Skinner, 2018). By making use of coding DNA regions, FDP therefore violates this coding/ non-coding division, as explained by the following interviewee:

The typical dilemma in all of this is that in most European countries that have forensic DNA legislation, it was produced in the 90s, at a time when nobody wanted or could actually do more than standard forensic DNA profiling, so therefore the laws were adapted to this use. For instance, assuming that only non-coding markers were used, which of course in this case you would violate.

(Interview A02)

This implies the existence of a variable scenario in terms of FDP regulation across Europe. It is specifically regulated in countries such as the Netherlands, Slovakia, and Germany (Amelung, 2021; Amelung \& Machado, 2021; M'charek, 2008; Samuel \& Prainsack, 2018a), while other European countries possess only implicit or absent legislation on FDP. Such legal vacuums, therefore, lead to varying interpretations about the use of FDP in the criminal justice system (Samuel \& Prainsack, 2018a) which, in some cases, implies that decision-making is placed upon local forensic users (Wienroth, 2018).

Within a framework providing little guidance (Wienroth, 2018), most forensic geneticists adopt a position in defence of the need to update legislation that can respond to the actual capabilities of forensic DNA technologies. Thus, FDP provides an insightful analysis into how, despite their consolidated role in providing evidence for criminal justice, there has been a continuous investment to further expand DNA technologies' genetic informativity (Machado \& Granja, 2020). Interviewed professionals argue for the introduction of changes in the law to allow for the use of FDP in specific situations, such as cases involving crimes that are considered serious ("I think it should also be done only in serious crime cases. Like capital crime cases, where there is a very urgent public interest to identify the perpetrator," Interview O01), while establishing clear demarcations regarding the types of information contemplated for analysis (externally visible appearance instead of "invisible" traits). According to this position, the push for FDP's implementation is coupled with a stand on its restrictions to preserve forensic genetics' social legitimacy. 


\section{The promises of forensic DNA phenotyping}

The potential of FDP to construct a composite face of an unknown suspect is highly powerful and attracts interest among diverse actors, ranging from the forensic industry, policymakers, the media and the general public. Forensic geneticists have different ways of maintaining a cautious position to deal with overly positive expectations created by the promise of FDP, nurtured by the pervasiveness of a growing market with an interest in the marketization of science. Notwithstanding their interest in underlining FDP's potential to advance criminal investigations, geneticists' discourses also convey the everpresent epistemic risk - degrees of certainty or uncertainty involved in the interpretation of forensic DNA technologies (Lawless, 2010, p. 381) - associated with FDP. In other words, forensic geneticists present FDP as a "semi-transparent box ... neither fully opaque nor fully transparent" (Kruse, 2015, p. 115) in which the associated epistemic risks remain visible (Granja \& Machado, 2020). Interviewed experts show significant reservations about unduly positive expectations placed on this technology with disregard for its inherent epistemic risk and limitations. In their view, such confidence is based on a hype construed by a series of commercial, entertainment and media interests:

But I also think that the expectations, again, are excessive for this technology. There is an over expectation of what we can achieve using the new technologies, at the time being.

(Interview O01)

I think occasionally some scientists, companies, and the media, tend to hype up these things and put a spin on their presentation which greatly exaggerates their potential.

(Interview D11)

According to forensic geneticists interviewed for this study, overly positive expectations have pernicious consequences, inasmuch as they imply a disjunction between the type of inferences FDP is able to produce and the aims police investigators have in mind for this technology. As explained by the following interviewee, police forces often demand information from this kind of genetic testing which it cannot provide:

Quite often we get asked by police investigators to try and distinguish somebody from the Middle East, or North Africa, from people of European origin. And that is not always as easy as people might think. So, we have the ethical issue, it is an ethical issue, of police expectations before we do the test. So they make a lot of assumptions about the capacity of the genetic tests, because they watch CSI on television.

(Interview C04) 


\section{Genetic Surveillance and Crime Control}

Forensic geneticists, therefore, engage with what John Gardner and colleagues call "recalibration" as innovation work (Gardner et al., 2015) referring to how pioneering clinical teams manage the tension between highly optimistic and hyped visions of the future surrounding biomedical innovations, and the exigencies of delivering "effective" interventions on patients. In the case of FDP, "recalibration" means adjusting the overly optimistic expectations placed by police officers on the type of information FDP might provide to advance criminal investigations.

The possibility of inferring the appearance of a given individual has attracted the attention of private companies interested in the commercialization of forensic services. On this point, our interviewees repeatedly mention the practices and proactive commercial behavior of Parabon Nanolabs, a company that commercializes a service called Snapshot (Wienroth, 2020a). Snapshot is a tool that allegedly enables a prediction of the appearance, including face morphology, of an unknown individual. Forensic geneticists in this study clearly seek to distance themselves from such commercial efforts. From their discourses, we understand that so far FDP "Is not really predicting face shape but it is inferring aspects of appearance" (Interview D11). Forensic geneticists, therefore, express considerable reservations about companies who promise a genetic photofit. In their abuse of what interviewees perceive as the normative standards for good science (practices of transparency, peer-review validation, and reproducibility), such endeavors are considered scientifically unsound, solely driven by commercial interests (Granja \& Machado, 2020; Wienroth, 2020a). As outlined in the following quotation:

The methods they are offering, at least for the physical prediction of externally visible traits, they are not validated, and I think they are not ready for case work. And so I am a bit worried, because if you were a scientist you would not do that.

(Interview O01)

As widely discussed by social scientists studying the ethical implications of FDP, this technology has the power to generate a new set of collective suspects in ways that might reproduce stigmatization and criminalization (M'charek, 2008; Sankar, 2010; Skinner, 2018). Such stigmatization and criminalization mainly targets racialized populations, insofar as FDP contributes to reinforce racial categories (Hopman \& M'charek, 2020; M'charek, 2013; M'charek et al., 2020). Considering the possibility of perpetuating social prejudice through the use of FDP in the criminal justice system, forensic geneticists uphold that legitimate use of FDP must be limited to the investigative phase of a criminal investigation, as the following interview quotation illustrates:

I don't see anything wrong in using FDP in the investigative stage, nothing which can be seen as remotely wrong ethically. And that's not all: it improves something I know to be usually incorrect, one of the biggest contributing factors to false accusations and false charges.

(Interview C05) 
Within such framework, optimist outlooks on FDP would find their counter point in the inclination to exclude this technology in favour of continuing to rely on misleading eyewitness testimonies. Interviewees therefore promote a techno-scientific solution to the inherent errors of eyewitness testimonies, rooted in imaginaries about the power of forensic DNA technology to solve complex social issues. Arguing that eyewitness accounts are fragile, pervaded by emotions, motivations, subjectivities and informational gaps, participants of this study refer to FDP as a "neutral" technology, immune to social bias. In the words of one participant:

The point is this, there is a lot more prejudice, or rather, people are much more biased than DNA trials. For instance, an eye witness might be more prone to describe an assailant (...) as belonging to a racialized group or as an African-American than a Caucasian, right? Why? Because he/she may be prejudiced. DNA analysis will not have that kind of bias, it will determine that the suspect belongs to this or that group. Therefore, I believe phenotype inference to be much more objective than eye witness accounts and nevertheless, eye witnesses continue to be accepted in court.

(Interview N23)

Although some interviewees mitigate the discriminatory potential of FDP through direct comparison with eyewitness accounts, thus underlining DNA's alleged neutrality, others fully recognize such potential, but mitigate its relevance by highlighting other issues. The following participants, for example, explain that while FDP can indeed be used to point suspicion on a particular group, it might also lead investigations away from them.

If I go to a village and can predict with 70 or 80 percent probability that the person leaving traces is dark-skinned or perhaps of southern African descent or something like that, this may lead to discrimination. At this point of an investigation it is commonly overlooked that in many cases, the trace may apply to a fair-skinned person and, so to speak, all the dark-skinned people are exonerated at first.

(Interview O10)

Increased risk that racial profiling might take place. We don't really see that risk from the scientific point of view and also from our discussions with the police forces. (...) It can be the case that police investigations are led toward a certain group of people, yes, but it can also lead away from certain group of people; and it can lead towards the vulnerable people but also away from vulnerable people.

(Interview 013)

Another argument usually invoked by forensic geneticists while assessing FDP's discriminatory potential is that its propensity to focus on a particular racial group does not constitute a valid reason to abandon the investigation of 


\section{Genetic Surveillance and Crime Control}

a certain crime. Some interviewees defend that the potential to solve a crime must be considered more important than the potential of the technology to reinforce the stigmatization of a particular group. In the words of an interviewee:

I am not one to take the view that because a particular type of genetic test might be seen as placing a particular ethnic group in the frame, so to speak, it is reason enough to reject it. I think it is a reason to handle it carefully and sensitively. Ultimately, I do not see it as a reason not to do it. And there are many different reasons for that: one is that a crime is a crime, and you cannot stop investigating them just because people might get upset. And undoubtedly, vilification is a consequence; it is a social issue that needs to be addressed, but I suspect it is secondary to the criminal investigation issue itself.

(Interview D11)

One other way forensic geneticists have to deal with FDP's discriminatory potential is by displacing the discussion away from the scientific field. They do so by establishing clear boundaries between their field of expertise and police work. A distinction between knowledge production and its applications and its uses is deliberately maintained and generally accepted (Lynch et al., 2008), ensuring the protection of scientific autonomy (Granja \& Machado, 2020).

And I don't want to say that there is no risk of racial profiling within the police, I think that this is a completely different discussion and it's a discussion that the police needs to have; I'm pretty sure that there are all kinds of people within the police and I think we all know that there is a risk. But the risk is completely independent of how we type the sample.

(Interview 013)

But this problem of stigmatization and targeting a particular community can potentially be damaging to community relations, or the relationships between the police and that community. And it is open to some abuse. There is the worry that the police will abuse that knowledge or abuse the fact that they are looking for a particular type of suspect to further prejudice their attitudes towards to that community.

(Interview C04)

Therefore, forensic geneticists' views acknowledge racial discrimination as a question de facto, which forensic genetics cannot and should not attempt to solve, but can only work around. Forensic geneticists thereby "work around" FDP's discriminatory potential by acknowledging that eyewitness accounts might also lead to discrimination, underlining that FDP can also work to clear suspicion from a certain group of individuals, and to decouple the prerogatives of science and law. More specifically, forensic geneticists locate FDP's potential to reproduce stigmatization and criminalization in the 
longstanding structures of power and inequality that affect the interaction between law enforcement and racial minorities, thereby displacing this discussion away from the realm of science (Granja \& Machado, 2020).

\section{Next generation sequencing}

\section{The promises of NGS}

Unlike FDP, which has been already used in a number of criminal cases, albeit limited, NGS is still in an exploratory stage. Allegations of its promising character are present in the discourses of most forensic geneticists. The promise of NGS assumes multiple and fluid meanings. Specifically, some forensic geneticists viewed NGS as the next step in future forensics, while others believed that NGS might already provide relevant outputs to this field in the present. These nuances as to NGS's promising nature - and the expected new possibilities associated with it - can be understood in relation to differing locations of the forensic geneticists within a developing network of innovation relationships.

Among respondents who recognized the promising character of NGS in the near future, the most recurrent expectation was to consider that these technologies would be completely established in the forensic field scenario in five or ten years' time. This group of participants seemed to construe NGS according to a vision where, "until proven otherwise," technological advances are beneficial. More specifically, forensic geneticists in this study emphasize NGS's ability to create new opportunities for research and open up new possibilities for providing criminal investigators with investigative leads, thereby improving the quality of the services provided by laboratories to the criminal justice system. The following interview quotation exemplifies a discursive stance that considers NGS to be currently applicable in research only, but admits it will be a matter of time before it can be used in concrete case work:

If we are looking at 10 years [into the future], I think we have made the switch from the old-fashioned way of doing DNA typing to the new techniques, so NGS. (...) We will use the technology, but not in the same way as it is used in clinical genetics. We will only use it to obtain the information needed to solve crimes. And I do hope in 10 years' time we will be able to provide even more answers with respect to the traces left at a crime scene. And to do it increasingly in real time.

(Interview A05)

Such views reflect what Nik Brown and Mike Michael (2003) designated as engaging with the future as an analytical object to understand innovation processes. In the authors' words, the future is "...not simply a neutral temporal space in which objective expectations can be projected [but instead] the 


\section{Genetic Surveillance and Crime Control}

future is mobilized in real time to marshal resources, coordinate activities and manage uncertainty" (Brown \& Michael, 2003, p. 4). Other participants conveyed their belief in the ability of NGS to have a profound impact in the field of forensic genetics already in present time. We should note, however, that this group of forensic geneticists display differentiated positions within a developing network of innovation relationships, inasmuch as they either reported having close relationships with commercial providers or were benefiting from research funding enabling the purchase of NGS equipment. Considering their current resources, such interviewees tended to have an optimistic view on NGS' promising nature, projecting a forward-looking statement onto the use of NGS in the immediate present. On this point, one of the participants makes an enthusiastic description of a research project focused on NGS and funded by the European Union that involves scientists, police forces and commercial companies, with the aim to develop global standards and a nomenclature adjusted to new techniques:

We've just started [a new project funded by the European Union], we're talking to all the commercial companies we had in our contact list to ask them for prototypes that are liable to be compatible with the markers we're already using (...) The idea is to evaluate the fundamental theme of nomenclature; we need a globally standardized nomenclature so it can be understood. (...) Secondly, we'll focus on communication: on which standards to promote and on whether we will develop a software to introduce those standards. To create the fundamental base for a standardized international nomenclature to enable a successful communication (...) I believe we're reaching a third revolution in technology, which is mass sequencing. It's the future...

(Interview C01)

Besides interviewees who obtained funding for conducting research within NGS, one other group that is also highly optimistic about NGS' potential comprises interviewees with close connections to private companies that provide services and material. In this case, we take the words of the following participant as an example, describing how the collaboration of his/her laboratory with a commercial provider created the conditions for using NGS in case work. The interviewee mentions the organizational changes that had to be implemented in order to create the necessary conditions for the uses of these promissory technologies:

So, we have installed a [NGS] workflow in our laboratory. We developed a collaboration with companies that helped us to automatize all the analysis. And so we are starting now to really use NGS to apply them in real casework. (...) I think a lot of laboratories should actually do the same, because it is a very promising technology. 
As we explored in the previous section of this chapter, forensic geneticists argue that FDP should only be applied to serious cases where no other investigative leads are available, thereby underlining its investigative value (Granja \& Machado, 2020; Wienroth, 2018). NGS elicits a different set of perspectives. Instead of being associated with the seriousness of the crime, the selective use of NGS in the criminal justice system is equated with the technical specificities of the biological samples collected from crime scenes. As the following interviewee points out, complex mixtures, for example, are particularly suitable to NGS:

Well, it is not so much a special kind of crime [that justifies the use of NGS] as a special type of DNA profile. In complex mixtures, which we encounter quite regularly in routine forensic DNA research, capillary electrophoresis fails to provide reliable answers in many cases. And in those samples, [NGS] can provide a much better answer in many instances. And that was the main reason why we developed [NGS]. And that is exactly the kind of samples which we now use to deconvolute using [NGS]. That is the biggest challenge. So, it will not be a routine tool, it will be used in a limited number of samples from all kind of different cases.

(Interview A03)

NGS is thus considered by interviewees as particularly useful for specific types of DNA, such as mixture cases and degraded DNA samples, which tend to raise problems when analyzed using traditional methods. This view is shared by most of our interviewees, as the next quotations shows:

It gives a lot of additional information; can be very helpful, for example, in DNA mixtures from various persons. We already know that there are real breakthrough in distinguishing identical twins. So, it's a very, very useful technique, obviously.

(Interview O13)

I am interested in what it provides; it provides us with a whole new layer of complexity and differentiation. (...) And I am looking at completely new markers that are only possible with massively parallel sequencing; they look like they will be very good for mixture interpretation, they will be short, so they will be good for degraded DNA and they provide a lot of information per marker.

(Interview C04)

Thus, from the standpoint of interviewees, the decision as to whether or not to make use of NGS in their technical specificity, should be assigned exclusively to forensic geneticist professionals. At a time when forensic genetics is undergoing a transitional stage (Granja, 2020; Machado \& Granja, 2020), this concern reflects an effort to re-assert boundaries of expertise and protect the monopoly over such decisions. 
Although among our interviewees there is a relatively common tendency to characterize NGS as a "revolution," we also find participants who challenge this view. One participant confided that the initially optimistic expectations about an NGS revolution have since waned. This participant was expecting a kind of revolution that would render previous technologies obsolete, but currently believes that the methods already in place will continue to co-exist with the new methods enabled by NGS. This participant explicitly alludes to NGS's revolutionary representation, claiming that rather than "marking a revolution," this new technology can be useful to increase the robustness of already-in-use technologies:

We expected massive parallel sequencing to be something like a revolution and to completely replace the current technology that we use, but it didn't happen. And I personally don't think it's going to happen. (...) we obviously need massive parallel sequencing for biogeographic origin or for externally visible traits because we do have to analyze so many individual markers that we do have to use a method like this. So this is the impact that it will have. But a few years back, I would've expected it to completely replace the current method of PCR and the fragment size analysis. Now I'm pretty sure it will not replace it.

(Interview O13)

This account fits a pattern of expectations about scientific and technological change described by Nik Brown and Mike Michael (2003) as "retrospecting prospects," whereby people refer to past representations of the future. The authors claim that this particular interpretative pattern frequently goes hand-inhand with "prospecting retrospects," whereby past futures are incorporated into real-time constructions of the future (Brown \& Michael, 2003, pp. 4-5). These expectations help social actors to make sense of past and present expectations and to manage or engage with changing needs of innovation.

According to one of our interviewees, the expected coexistence of new and old systems is based on the strength of the current system, whose ability to institute a "shared universal language" makes the implementation of a new system unlikely. In this sense, most interviewees perceive NGS as playing a complementary role in forensic DNA analysis, by expanding genetic informativity in cases in where it might be considered useful. As expressed in the following interview quotation:

Never to replace what we already have, since I think STRs can hardly be discarded, because they provide a lot of information and because they have become a universal methodology and so we all speak the same language; but I think that it will add another source of information and in that sense I think it will be good (...) As far as I'm concerned [NGS] goes in the direction of complementarity. 
In sum, although interviewees agree that NGS contains a "revolutionary" potential to expand genetic informativity, especially in the most challenging cases, they also consider it will not necessarily substitute previously established technologies with long-standing records of implementation, consolidation and standardization (Aronson, 2007; Derksen, 2003, 2010; Lynch et al., 2008). Forensic geneticists recurrently mention, for example, that NGS will very unlikely make substantial changes in DNA databasing, as expressed in the words of one of the participants:

It [NGS] has enormous advantages insofar as the core markers that we use, which are in the databases, can be continued. But along with those core markers, we can provide more information.

(Interview D09)

In the next section we explore how forensic geneticists view the pros and cons of expanding genetic informativity through NGS. While embracing the new opportunities brought by NGS, forensic geneticists also reflect critically upon how much more data - and more sensitive information deriving from genetic data - is really needed to provide meaningful and useful responses to the criminal justice system.

\section{Between research science and forensic applied science}

The overwhelming majority of forensic geneticists we interviewed frequently mentioned the costs of NGS as the main reason not to use these techniques on a routine basis. The following interview excerpts reveal this concern among interviewees, who tend to find that until the costs of NGS decrease, there is no reason to invest in new techniques which will require, among other aspects, purchasing new equipment and reagents, training and organizational changes in work procedures and communication with courts. According to the following participants, before economic costs are substantially reduced, there are no significant advantages in investing in NGS:

[NGS] has to be cost effective, if it is going to replace the methods that we have now, it has got to be cheaper. Yes! That is the most important thing. [NGS] becomes very cheap; that will be an argument to replace current technology.

(Interview Q01)

The field is moving, but slowly, because this is big, big money (...) there is hope, but it is expensive. (...) Costs have to go down. (...) You ask for a lot, namely when you think about asking a routine forensic laboratory that has spent I don't know how many years, if not decades, establishing the current technology, to start again. So the question becomes, what is it for? what is the prize? 
I think it is a lot of extra effort for nothing, it doesn't provide anything that we are not already getting.

(Interview X03)

In addition to high costs, forensic interviewees also recurrently point out that NGS is still being developed and needs to undergo an operational validation processes. As noted by Matthias Wienroth (2020b), within the framework of a responsible approach to innovation, reliability must be taken into consideration, not only at the development and pre-adoption phases, where reliability of the underlying science and veracity of data work are assessed, but also in the adoption phases, where its reliability in terms of data safety, security, and suitability is evaluated. According to the following interviewee, NGS is still lacking the process of validation that ensures its reliability in the adoption phase.

Well, this [NGS] is something completely new. Personally, I believe this is really nice science and research. But it is not yet ready for case work. And the main reason is ... well, the very practical reason is that there is no proper forensic validation yet. At the case work level, that is, obviously not scientifically nor in principle. I mean, we all know it works, and there have been nice examples, but it is a different thing to get ISO accreditation and then to do a sort of scientific validation study.

(Interview O01)

Within this framework, interviewees frequently reflect upon the different aims of research science and forensic applied science (Cole, 2013). According to Simon Cole's categorization, research science has an open-ended time-frame, with general knowledge claims and an interest in continuously developing new knowledge aimed at achieving scientific "breakthroughs." However, the same cannot be said of forensic science applied to case work. Considering its limited time-frame, specific goal (to identify criminal suspects) and bureaucratic structure, forensic science applied to routine case work requires constant evaluation of potential benefits versus the additional risks involved in using new methods. In the light of such differences, interviewees commonly view the innovation of NGS techniques as able to boost research and publications, but impractical in the near future in its application to case work, owing mainly to its high costs, lengthy processes and uncertainties about its effective benefits for the bulk of routine work.

Well, the time to obtain the profile is actually lengthier; all the steps are a bit more difficult, and also the interpretation of the profile is pretty complex, compared to conventional analysis. So, it is more like an a la carte thing that you use only when the traditional method does not work. 
Some laboratories may be rich enough to invest in NGS and make this predictive analysis, age estimation and other things, but these things are not so often used in real life. Really, there aren't that many cases where such information can be used.

(Interview G01)

Another reason why some consider NGS unfeasible for forensic casework use has to do with the "excessive" amount of information it produces. According to one of our interviewees:

[NGS] it is what I would call a kind of bioinformatics overkill, you know? It is the sort of data that you cannot handle, and you do not need this data for most of the cases. Because current technology is more than enough in $90 \%$ or $95 \%$ of the cases.

(Interview O01)

Regarding the difference between research science and forensic applied science, forensic geneticists commonly find that currently the benefits of NGS are mostly for research science. According to the following interviewee, the strong push for routine work implementation is mostly a result of commercial interests, reflecting companies' focus on selling new products:

Well, at the moment [NGS is] a nice tool for research. When I was a researcher, it was always good to have a new technique to play around and then to publish the research; it's good to publish and a new technique offers many opportunities to do so. A second step is the implementation and routine case work. I don't really see that the benefit is so extreme. (...) I'm skeptical as to whether this is the perfect tool. It's good for ... well, obviously for those companies selling the machines; it's nice to sell and it's a nice technique to see working, but I'm skeptical if this will change our recent technique.

(Interview O09)

Besides operational and commercial issues, forensic geneticists also mention how NGS brings additional ethical issues that must be considered. The possibility opened by NGS to reconstruct the whole of the human genome raises many problems, uncertainties, and contingencies, leading forensic geneticists to consider that the data produced are too sensitive, and therefore, liable to risks of misuse. Considering its potential, participants in this study thus find there is a need to implement forms of regulation over the forensic use of NGS that will mitigate associated risks.

At this time, [NGS] is able to sequence the human genome within hours (...) I can sequence the human genome and thus know everything about a person, their entire genetic code. If I cross that information with other 
medical information, it is perfectly possible to know things about that person that they may not want disclosed. So, it is already possible in theory. And since it is possible. It becomes a tool one must be very cautious with.

Forensic geneticists, however, claim the monopoly of decision making about which genetic data should or should not be analyzed, for their own community. Thus, forensic geneticists engage with setting norms and values to ensure their compliance with normative points of reference on how to make an adequate and legitimate use of NGS in the criminal justice system - what Matthias Wienroth (2018) calls "self-anticipatory practices." Such a position simultaneously legitimizes forensic geneticists' way of producing scientific knowledge and re-asserts the social boundaries of expertise and authority of the scientific community of forensic genetics, as the following interview quotation highlights:

If I get the whole genome, it will give me all the information about a person, from things without any forensic relevance to all the phenotypic markers of ancestry. Now everything depends on what I want to inspect. Can this be a good thing? It can. Can it be a bad thing? Yes, it all depends on how it is used. (...) I don't know, it can be important just as it can be dangerous (...) I want to be able to choose whether or not to inspect a particular set of markers.

(Interview N23)

Expectations regarding NGS, therefore, range from the highly enthusiastic views of NGS as the future standard in DNA analysis, to more cautious approaches to this technology as a complementary forensic tool that might expand genetic informativity of DNA profiles in cases where the existing methods have not been successful. These different views correspond to forensic geneticists' divergent locations within a developing network of innovation relationships. More specifically, NGS puts the differences between research science and forensic applied science into focus (Cole, 2013), as well as the differentiated access to resources among forensic geneticists. While those professionals who have access a wide range of resources, owing to research funding and/or collaborations with equipment providers, tend to be more optimistic about the potential of NGS, professionals who are more involved with routine case work tend to describe this technology as a time-consuming and expensive process with arguable added benefits.

\section{Long-range familial searches: another step towards expanding genetic informativity}

Among the technologies aimed at expanding genetic informativity within forensic science, more recently there has also been a significant focus on long- 
range familial searches conducted in recreational DNA databases (where citizens voluntarily upload genetic information) (Granja, 2020; Kennett, 2019; Murphy, 2018). Long-range familial searches are also commonly referred to as forensic genealogy (Phillips, 2018; Syndercombe-Court, 2018). Briefly, it refers to a procedure by which a crime scene sample is uploaded into a recreational DNA database in order to search for relatives of potential suspects. It differs significantly from previous approaches, inasmuch as searches are no longer restricted to individuals who have had some kind of involvement with the criminal justice system, as occurs in forensic DNA databases.

Long-range familial searches became a focus of interest in the aftermath of the Golden State Killer ${ }^{1}$ investigation of 2018. Criminal investigators on that case used DNA from crime scenes and uploaded the genetic information into an online public-access DNA database, GEDmatch ${ }^{2}$. Based on that search, officers found partial matches with the profile of the presumed suspect, which were assumed to belong to distant relatives. Following up the partial match, family trees were built based on information collected from several other sources (social media and other types of online records), leading to the identification of 72-year-old Joseph James DeAngelo as a suspect, after which his "abandoned" $\mathrm{DNA}^{3}$ was collected to conduct further analysis. The result of the tests confirmed it matched the crime scene samples.

Since the Golden State Killer, several criminal investigations have been solved through long-range familial searches, not only in USA but also in Sweden and Canada (Granja, 2020). This is possible due to the transnational nature of recreational databases, given that direct-to-consumer companies provide services across several countries (Skeva, Larmuseau, \& Shabani, 2020). Criminal investigations that resort to long-range familial searches, however, occur within a framework characterized by a lack of regulatory oversight (Kennett, 2019; Murphy, 2018). This implies that companies in the market react differently to law-enforcement searches: while some claim to resist law-enforcement inquiries, others welcome long-range familial searches for criminal investigation purposes (Granja, 2020).

According to Rafaela Granja (2020), long-range familial searches have three significant implications, namely, the expansion of affected populations, the participatory turn, and the co-production of biovalue. In brief, the expansion of affected populations means that the use of SNPs genetic informativity in longrange familial searches enables locating distant relatives and targeting a population that is usually not included in forensic DNA databases, namely an economically privileged population comprising European-descent individuals (Murphy, 2018). The participatory turn refers to the possibility opened up by long-range familial searches to allow individual citizens, interested in personal genomics and who have already purchased a direct-to-consumer genetic test, to make their data available for law-enforcement activities. The implication here is that involvement with the criminal justice system is no longer a pre-requisite to participate in law enforcement DNA database searches. Finally, the co-production of biovalue 
means that individuals who voluntarily participate in databases available for law enforcement searches are lending their genetic information to create a resource whose significant commercial potential will be marketed by several specialized companies (Granja, 2020).

Long-range familial searches, together with FDP and NGS, thus represent another step towards expanding genetic informativity in ways that imply: further compounding the interrelated dimension between individual and collective identification; blurring the boundaries between coding and non-coding DNA; increasing commodification of genetic knowledge and marketization of science, and a general move from forensic genetics towards forensic genomics. Such dynamics are coupled with a constant interplay between the hyped or low expectations that determine how forensic geneticists deal with this phenomenon in complex and unfolding ways, ranging from an interest in expanding genetic informativity to concerns about the preservation of forensic science's epistemic authority (Phillips, 2018; Syndercombe-Court, 2018).

\section{Conclusion}

This chapter aimed to explore how forensic geneticists perceive emerging technologies aimed at expanding genetic informativity, namely FDP and NGS. Inspired by the previous works on the role of "expectations" in scientific and technological innovations, frequently studied in fields as distinct as economics, sociology, the history and philosophy of science, as well as science and technology studies (Borup et al., 2006; Brown \& Michael, 2003; Kriechbaum, López Prol, \& Posch, 2018), we have analyzed how these professionals in the field of forensic genetics manage the tension between hyped visions of innovation and concerns about the exigencies of criminal case work that is surrounded by controversies and uncertainty.

In the case of FDP, forensic geneticists sustain FDP's added value to criminal investigations, while also underlining its epistemic risk, investigative character and selective use in serious cases. The overly positive expectations of police officers demand a negotiation between expectations and concrete outcomes in criminal cases. FDP also implies managing the pervasiveness of a growing market, interested in a marketization of science that does not necessarily correspond to forensic geneticists' standards of "good science" (Granja $\&$ Machado, 2020). In addition, forensic geneticists deal with FDP's discriminatory potential by allocating this ethical and political discussion on longstanding structures of inequality, situated "outside" the scientific domain, thereby displacing the consequences of using FDP, transferring responsibility from the realm of science to the realm of criminal investigation and courts (Granja \& Machado, 2020).

Regarding NGS, we argue that forensic geneticists' expectations are heterogeneous and flexible, coupling "hypo" and "optimistic" expectations that portray NGS as a revolution with modest and uncertain outlooks, characterized by skepticism about NGS's added value in routine case work. Such 
diverging positions are influenced by forensic geneticists' relative locations within a developing network of innovation relationships, namely in terms of access to resources or the type of work being conducted, whose focus could be more centered either on research science or on forensic applied science.

One other particularly relevant issue when it comes to NGS, is the disjunction between the legitimation of its selective use and the specificities of the criminal cases it must apply to, as we see with FDP and other innovative technologies in cases of serious crimes with great social impact. NGS use is considered to be solely dependent upon the specificity of the DNA collected from the crime scene. This implies that the decision-making process on whether or not to use NGS, becomes independent of social and contextual criteria and totally framed according to scientific criteria. By placing decision-making processes exclusively in the hands of forensic geneticists, NGS use actually reinforces the credibility of scientific assertions and re-asserts boundaries of expertise. In the light of this, the forensic community claims its monopoly on decision making, not just on which cases should be eligible for NGS use, but also on the type of genetic data might or might not be analyzed.

It is important to note that forensic geneticists' heterogeneous relation to expectations about FDP and NGS, reveal two main interrelated concerns, where technical, organizational, and social aspects of innovation are tightly intertwined. On the one hand, they aim to protect forensic geneticists' workspace and sphere of expertise from the turbulence of transitional and transformative stages of epistemological, methodological and regulatory uses of forensic genetics in the field of criminal investigation. On the other hand, expectations surrounding FDP and NGS use, enable forensic geneticists' engagement with modes of "anticipatory governance" (Tutton, 2011; Wienroth, 2018), whose discussion of reliability, utility and legitimacy-related issues, are mobilized by forensic geneticists toward the protection of forensic science's credibility and autonomy (Wienroth, 2020b). These types of efforts are increasingly relevant as more technologies, such as FDP, NGS, and longrange familial searches, enter into the imagined futures of forensic genetics.

By focusing upon FDP and NGS, along with a brief discussion on longrange familial searches conducted by privately owned recreational DNA databases offering genetic tests to consumers directly, this chapter outlined the horizons of on-going and future methods to expand genetic surveillance that might lead to increasing discrimination and conflicts with privacy. By focusing on FDP, we are able to understand an existing displacement of locus, from individualization (i.e., identification of specific individuals) to collective population groups. This results from clustering a suspect population that share biogeographical ancestry and/or externally visible characteristics. As we turn to NGS, we have shown that it is perceived as opening up a path to fully "personalized" genetics, e.g., in the sense that it promises to revolutionize the capability of forensic genetics to reach genetic uniqueness. However, in order to take any sort of practical actions, individuals must be reassembled into 
groups, and the efficacy of genetics can only be measured statistically across the group (Cole, 2018; M'charek \& Wade, 2020).

Expanding genetic informativity contributes to a prevailing trend that can be described as a molecularization of the body (Rose, 2007), rendering genetic suspects more vulnerable to isolation, manipulation, mobilization, recombination, in new practices of intervention, and subjected to social (and political) sorting. In sum, expanding genetic informativity by enrolling human appearance and "race" in the field of forensic genetics and by blurring the boundaries between the "medical" and the "criminal" (Machado \& Silva, 2015; Wienroth et al., 2014) creates new dilemmas for thinking and debating ethically responsible implementation and use of these technologies, specifically in forensic genetics practice and more broadly within the field of criminal justice.

\section{Notes}

1 The Golden State Killer is the name coined by Michelle McNamara to refer to a serial killer and rapist who committed at least 12 murders and more than 50 rapes in California, USA, between 1974 and 1986. He is believed to be responsible for three crime sprees throughout California, each of which spawned a different nickname in the press (East Area Rapist and Original Night Stalker) before it became evident, through DNA analysis, that they were committed by the same person.

2 GEDmatch is an online public-access public database where individuals with data originated from different testing companies can compare their DNA with others on the database in order to trace relatives. More information here: www.gedmatch. com/login1.php (last accessed May 13, 2019).

3 In the USA the police can collect "abandoned DNA," that is, a biological sample which has been left behind by the individual inadvertently or involuntarily, such as chewing gum or a tip of a cigarette. For a critical view of such procedures see (Joh, 2006).

\section{References}

Amelung, N. (2021). Politics of (Non)Belonging: Enacting Imaginaries of Affected Publics Through Forensic Genetic Technologies. In S. Khan, N. Khan, \& H. Machado (Eds), Racism and Racial Surveillance: Modernity Matters (173-198). London: Routledge.

Amelung, N. \& Machado, H. (2021). Governing expectations of forensic innovations in society: the case of 'extended DNA analysis' in Germany. New Genetics and Society, 1-22. https://doi.org/10.1080/14636778.2020.1868987.

Amorim, A. (2012). Opening the DNA black box: demythologizing forensic genetics. New Genetics and Society, 31(3), 259-270. https://doi.org/10.1080/14636778.2012. 687083.

Amorim, A. \& Pinto, N. (2018). Big data in forensic genetics. Forensic Science International: Genetics, 37, 102-105. https://doi.org/10.1016/J.FSIGEN.2018.08.001.

Aronson, J. (2007). Genetic Witness: Science, Law, and Controversy in the Making of DNA Profiling. Piscataway: Rutgers University Press.

Borup, M., Brown, N., Konrad, K., \& Van Lente, H. (2006). The sociology of expectations in science and technology. Technology Analysis \& Strategic Management, 18 (3/4), 285-298. https://doi.org/10.1080/09537320600777002. 
Brown, N. \& Michael, M. (2003). A sociology of expectations: retrospecting prospects and prospecting retrospects. Technology Analysis \& Strategic Management, 15(1), 3-18. https://doi.org/10.1080/0953732032000046024.

Brown, N. \& Rappert, B. (Eds.). (2000). Contested Futures: a Sociology of Prospective Techno-Science. London: Routledge. https://doi.org/10.4324/9781315259420.

Budowle, B., Schmedes, S.E., \& Wendt, F.R. (2017). Increasing the reach of forensic genetics with massively parallel sequencing. Forensic Science, Medicine, and Pathology, 13(3), 342-349. https://doi.org/10.1007/s12024-017-9882-5.

Cole, S. (2007). Is the "junk" DNA designation bunk? Northwestern University Law Review Colloquy, 102, 54-63.

Cole, S. (2013). Forensic culture as epistemic culture: the sociology of forensic science. Studies in History and Philosophy of Biological and Biomedical Sciences, 44(1), 36-46. https://doi.org/10.1016/j.shpsc.2012.09.003.

Cole, S. (2018). Individual and collective identification in contemporary forensics. BioSocieties, 15(3), 350-375. https://doi.org/10.1057/s41292-018-0142-z.

de Knijff, P. (2019). From next generation sequencing to now generation sequencing in forensics. Forensic Science International: Genetics, 38, 175-180. https://doi.org/10. 1016/J.FSIGEN.2018.10.017.

Derksen, L. (2003). Agency and Structure in the History of DNA Profiling: The Stabilization and Standardization of a New Technology [Doctoral Dissertation, University of California, San Diego].

Derksen, L. (2010). Micro/macro translations: the production of new social structures in the case of DNA profiling. Sociological Inquiry, 80(2), 214-240. https://doi.org/ 10.1111/j.1475-682X.2010.00328.x.

Dimeglio, C.E., Kelly-Irving, M., Lang, T., \& Delpierre, C. (2018). Expectations and boundaries for big data approaches in social medicine. Journal of Forensic and Legal Medicine, 57, 51-54. https://doi.org/10.1016/j.jflm.2016.11.003.

Fitzgerald, D. (2014). The trouble with brain imaging: hope, uncertainty and ambivalence in the neuroscience of autism. BioSocieties, 9(3), 241-261. https://doi.org/10. 1057/biosoc.2014.15.

Gardner, J., Samuel, G., \& Williams, C. (2015). Sociology of low expectations: recalibration as innovation work in biomedicine. Science, Technology, \& Human Values, 40(6), 998-1021. https://doi.org/10.1177/0162243915585579.

Granja, R. (2020). Long-range familial searches in recreational DNA databases: expansion of affected populations, the participatory turn, and the co-production of biovalue. New Genetics and Society, 1-22. https://doi.org/10.1080/14636778.2020. 1853515.

Granja, R. \& Machado, H. (2019). Ethical controversies of familial searching: the views of stakeholders in the United Kingdom and in Poland. Science, Technology, \& Human Values, 44(6), 1068-1092. https://doi.org/10.1177/0162243919828219.

Granja, R. \& Machado, H. (2020). Forensic DNA phenotyping and its politics of legitimation and contestation: views of forensic geneticists in Europe. Social Studies of Science, 1-19. https://doi.org/10.1177/0306312720945033.

Granja, R., Machado, H., \& Queirós, F. (2020). The (de)materialization of criminal bodies in forensic DNA phenotyping. Body \& Society, 1-25. https://doi.org/10.1177/ 1357034 X20919168.

Hedgecoe, A. (2010). Bioethics and the reinforcement of socio-technical expectations. Social Studies of Science, 40(2), 163-186. https://doi.org/10.1177/0306312709349781. 
Hedgecoe, A. \& Martin, P. (2003). The drugs don't work: expectations and the shaping of pharmacogenetics. Social Studies of Science, 33(3), 327-364. https://doi.org/10. 1177/03063127030333002.

Hindmarsh, R. \& Prainsack, B. (Eds.). (2010). Genetic Suspects: Global Governance of Forensic DNA Pprofiling and Databasing. Cambridge: Cambridge University Press.

Hopman, R. \& M'charek, A. (2020). Facing the unknown suspect: forensic DNA phenotyping and the oscillation between the individual and the collective. BioSocieties, 15, 438-462. https://doi.org/10.1057/s41292-020-00190-9.

Jasanoff, S. (1995). Science at the Bar. Law, Science, and Technology in America. Cambridge: Harvard University Press.

Joh, E.E. (2006). Reclaiming "abandoned" DNA: the fourth amendment and genetic privacy. Northwestern University Law Review, 100(2), 857-884.

Kayser, M. (2015). Forensic DNA phenotyping: predicting human appearance from crime scene material for investigative purposes. Forensic Science International: Genetics, 18, 33-48. https://doi.org/10.1016/j.fsigen.2015.02.003.

Kayser, M. \& de Knijff, P. (2011). Improving human forensics through advances in genetics, genomics and molecular biology. Nature Reviews Genetics, 12(3), 179-192. https://doi.org/10.1038/nrg2952.

Kayser, M. \& Schneider, P. (2009). DNA-based prediction of human externally visible characteristics in forensics: motivations, scientific challenges, and ethical considerations. Forensic Science International: Genetics, 3(3), 154-161. https://doi.org/10. 1016/j.fsigen.2009.01.012.

Kennett, D. (2019). Using genetic genealogy databases in missing persons cases and to develop suspect leads in violent crimes. Forensic Science International, 301, 107-117. https://doi.org/10.1016/j.forsciint.2019.05.016.

Konrad, K. (2006). The social dynamics of expectations: the interaction of collective and actor-specific expectations on electronic commerce and interactive television. Technology Analysis \& Strategic Management, 18(3-4),429-444. https://doi.org/10. 1080/09537320600777192.

Kriechbaum, M., López Prol, J., \& Posch, A. (2018). Looking back at the future: dynamics of collective expectations about photovoltaic technology in Germany \& Spain. Technological Forecasting and Social Change, 129(March 2017), 76-87. http s://doi.org/10.1016/j.techfore.2017.12.003.

Kruse, C. (2013). The bayesian approach to forensic evidence - evaluating, communicating, and distributing responsibility. Social Studies of Science, 43(5), 657-680. https://doi.org/10.1177/0306312712472572.

Kruse, C. (2015). The Social Life of Forensic Evidence. Oakland: University of California Press.

Lawless, C. (2010). Managing epistemic risk in forensic science: sociological aspects and issues. Sociology Compass, 4(6), 381-392. https://doi.org/10.1111/j.1751-9020. 2010.00280.x.

Lynch, M. (2013). Science, truth, and forensic cultures: the exceptional legal status of DNA evidence. Studies in History and Philosophy of Science Part C: Studies in History and Philosophy of Biological and Biomedical Sciences, 44(1), 60-70. https:// doi.org/10.1016/j.shpsc.2012.09.008.

Lynch, M., Cole, S.A., McNallly, R., \& Jordan, K. (2008). Truth Machine: The Contentious History of DNA Fingerprinting. Chicago: University of Chicago Press. https:// doi.org/10.1017/CBO9781107415324.004. 
Lynch, M. \& McNally, R. (2003). "Science”, “common sense", and DNA evidence: a legal controversy about the public understanding of science. Public Understanding of Science, 12(1), 83-103. https://doi.org/10.1177/0963662503012001246.

M'charek, A. (2008). Silent witness, articulate collective: DNA evidence and the inference of visible traits. Bioethics, 22(9), 519-528. https://doi.org/10.1111/j. 1467-8519.2008.00699.x.

M'charek, A. (2013). Beyond fact or fiction: on the materiality of race in practice. Cultural Anthropology, 28(3), 420-442. https://doi.org/10.1111/cuan.12012.

M'charek, A. (2020). Tentacular faces: race and the return of the phenotype in forensic identification. American Anthropologist, 122(2), 369-380. https://doi.org/10. 1111/aman.13385.

M'charek, A., Toom, V., \& Jong, L. (2020). The trouble with race in forensic identification. Science, Technology, \& Human Values, 45(5), 804-828. https://doi.org/10. $1177 / 0162243919899467$.

M'charek, A. \& Wade, P. (2020). Doing the individual and the collective in forensic genetics: governance, race and restitution. BioSocieties, 15(3), 317-328. https://doi. org/10.1057/s41292-020-00193-6.

Machado, H. \& Granja, R. (2018). Ethics in transnational forensic DNA data exchange in the EU: constructing boundaries and managing controversies. Science as Culture, 27(2), 242-264. https://doi.org/10.1080/09505431.2018.1425385.

Machado, H. \& Granja, R. (2020). Forensic Genetics in the Governance of Crime. Singapore: Springer Singapore. https://doi.org/10.1007/978-981-15-2429-5.

Machado, H. \& Silva, S. (2015). Public participation in genetic databases: crossing the boundaries between biobanks and forensic DNA databases through the principle of solidarity. Journal of Medical Ethics, 41(10), 820-824. https://doi.org/10.1136/m edethics-2014-102126.

Machado, H. \& Silva, S. (2019). What influences public views on forensic DNA testing in the criminal field? A scoping review of quantitative evidence. Human Genomics, 13(23), 1-13. https://doi.org/10.1186/s40246-019-0207-5.

McCartney, C., Wilson, T., \& Williams, R. (2011). Transnational exchange of forensic DNA: viability, legitimacy, and acceptability. European Journal on Criminal Policy and Research, 17(4), 305-322. https://doi.org/10.1007/s10610-011-9154-y.

Michael, M. (2000). Futures of the Present: From Performativity to Prehension. In N. Brown \& B. Rappert (Eds.), Contested Futures: A Sociology of Prospective TechnoScience (21-39). London: Routledge.

Murphy, E. (2018). Law and policy oversight of familial searches in recreational genealogy databases. Forensic Science International, 292, e5-e9. https://doi.org/10.1016/ j.forsciint.2018.08.027.

Nuffield Council on Bioethics. (2007). The forensic use of bioinformation: ethical issues. London: Cambridge Publishers. http://nuffieldbioethics.org/wp-content/uploads/ The-forensic-use-of-bioinformation-ethical-issues.pdf.

Phillips, C. (2018). The Golden State Killer investigation and the nascent field of forensic genealogy. Forensic Science International: Genetics, 36, 186-188. https://doi. org/10.1016/j.fsigen.2018.07.010.

Pickersgill, M. (2011). "Promising" therapies: neuroscience, clinical practice, and the treatment of psychopathy. Sociology of Health and Illness, 33(3), 448-464. https:// doi.org/10.1111/j.1467-9566.2010.01286.x.

Podlas, K. (2006). The "CSI effect": exposing the media myth. Fordham Intellectual Property, Media and Entertainment Law Journal, 16, 429-465. 
Prainsack, B. \& Toom, V. (2010). The Prüm regime. Situated dis/empowerment in transnational DNA profile exchange. British Journal of Criminology, 50(6), 11171135. https://doi.org/10.1093/bjc/azq055.

Prainsack, B. \& Toom, V. (2013). Performing the union: the Prüm decision and the European dream. Studies in History and Philosophy of Biological and Biomedical Sciences, 44(1), 71-79. https://doi.org/10.1016/j.shpsc.2012.09.009.

Queirós, F. (2021). The (Re)Invocation of Race in Forensic Genetics Through Forensic DNA Phenotyping. In S. Khan, N. Khan, \& H. Machado (Eds.), Racism and Racial Surveillance: Modernity Matters (199-225). London: Routledge.

Quinlan, A. (2020). The rape kit's promise: techno-optimism in the fight against the backlog. Science as Culture, 1-25. https://doi.org/10.1080/09505431.2020.1846696.

Reed, K. \& Syndercombe-Court, D. (2016). A comparative audit of legislative frameworks within the European Union for the collection, retention and use of forensic DNA profiles. EUROFORGEN - NoE. London. www.euroforgen.eu/fileadmin/web sites/euroforgen/images/Dissemination_Documents/WP4/Reed_and_Syndercombe_ Court_2016_Legal_Audit.pdf.

Rose, N. (2007). The Politics of Life Itself: Biomedicine, Power, and Subjectivity in the Twenty-First Century. Princeton: Princeton University Press.

Samuel, G. \& Prainsack, B. (2018a). The regulatory landscape of forensic DNA phenotyping in Europe. VISAGE, 1-119. www.visage-h2020.eu/Report_regulatory_la ndscape_FDP_in_Europe2.pdf.

Samuel, G. \& Prainsack, B. (2018b). Forensic DNA phenotyping in Europe: views "on the ground" from those who have a professional stake in the technology. New Genetics and Society, 38(2), 119-141. https://doi.org/10.1080/14636778.2018.1549984.

Samuel, G. \& Prainsack, B. (2019). Civil society stakeholder views on forensic DNA phenotyping: balancing risks and benefits. Forensic Science International: Genetics, 43(102157), 1-9. https://doi.org/10.1016/j.fsigen.2019.102157.

Sankar, P. (2010). Forensic DNA phenotyping: reinforcing race in law enforcement. In I. Whitmarsh \& D. Jones (Eds), What's the Use of Race? Modern Governance and the Biology of Difference (49-62). Cambridge: The MIT Press.

Scudder, N., McNevin, D., Kelty, S.F., Walsh, S.J., \& Robertson, J. (2018). Massively parallel sequencing and the emergence of forensic genomics: defining the policy and legal issues for law enforcement. Science \& Justice, 58(2), 153-158. https://doi.org/ 10.1016/J.SCIJUS.2017.10.001.

Selin, C. (2008). The sociology of the future: tracing stories of technology and time. Sociology Compass, 2(6), 1878-1895. https://doi.org/10.1111/j.1751-9020.2008. 00147.x.

Skeva, S., Larmuseau, M.H., \& Shabani, M. (2020). Review of policies of companies and databases regarding access to customers' genealogy data for law enforcement purposes. Personalized Medicine, 17(2), 1-14. https://doi.org/10.2217/pme-2019-0100.

Skinner, D. (2018). Forensic genetics and the prediction of race: what is the problem? BioSocieties, 15, 329-349. https://doi.org/10.1057/s41292-018-0141-0.

Syndercombe-Court, D. (2018). Forensic genealogy: some serious concerns. Forensic Science International: Genetics, 36(July), 203-204. https://doi.org/10.1016/j.fsigen. 2018.07.011.

Tutton, R. (2011). Promising pessimism: reading the futures to be avoided in biotech. Social Studies of Science, 41(3), 411-429. https://doi.org/10.1177/0306312710397398.

van Merkerk, R.O. \& Robinson, D.K.R. (2006). Characterizing the emergence of a technological field: expectations, agendas and networks in Lab-on-a-chip technologies. 
Technology Analysis \& Strategic Management, 18(3-4),411-428. https://doi.org/10. 1080/09537320600777184.

Wienroth, M. (2018). Governing anticipatory technology practices. Forensic DNA phenotyping and the forensic genetics community in Europe. New Genetics and Society, 37(2), 137-152. https://doi.org/10.1080/14636778.2018.1469975.

Wienroth, M. (2020a). Socio-technical disagreements as ethical fora: Parabon NanoLab's forensic DNA Snapshot ${ }^{\mathrm{TM}}$ service at the intersection of discourses around robust science, technology validation, and commerce. BioSocieties, 15(1), 28-45. https://doi.org/10.1057/s41292-018-0138-8.

Wienroth, M. (2020b). Value beyond scientific validity: let's RULE (Reliability, Utility, LEgitimacy). Journal of Responsible Innovation, 7(Sup1), 92-103. https://doi.org/10. 1080/23299460.2020.1835152.

Wienroth, M., Morling, N., \& Williams, R. (2014). Technological innovations in forensic genetics: social, legal and ethical aspects. Recent Advances in DNA and Gene Sequences, 8(2), 98-103.

Yang, Y., Xie, B., \& Yan, J. (2014). Application of next-generation sequencing technology in forensic science. Genomics, Proteomics and Bioinformatics, 12(5), 190-197. https://doi.org/10.1016/j.gpb.2014.09.001. 


\section{Non-Governmental Organizations and the Critique of Genetic Surveillance}

\section{Introduction}

The phenomenon involving the creation and development of large genetic databases designed to host the data of thousands of citizens, coupled with the new developments in the field of forensic genetics as an aid to criminal investigation, has triggered fears of a threat to privacy and a constriction of human rights such as the notions of equality before justice and presumption of innocence. Representatives of non-governmental organizations (NGO) from several European countries have started a public debate denouncing the risks posed by genetic surveillance regarding their application in the criminal justice system (Williams \& Johnson, 2004; Williams \& Wienroth, 2014, 2017).

Generally speaking, such NGOs envisage scenarios where governments are equipped with excessive surveillance power, while representing themselves as essential in their role as watchdogs. In this context, NGOs consider that their central mission is to spearhead a critical voice regarding the expansion of biometric surveillance technologies. In particular, to raise public awareness as to the problems surrounding genetic data, owing to their especially sensitive nature and the extremely high level of information contained therein regarding a wide range of human features (from information on physical features, to health condition, biological kinship, etc.) (Nuffield Council on Bioethics, 2007). Civil society organizations also express concerns about an overemphasis on criminality-related genetic explanations and the enunciation of apprehensions regarding the retention of children's DNA and the overrepresentation of specific minorities in genetic databases (Amelung \& Machado, 2019; Skinner, 2012).

This chapter aims to explore the views expressed by European-based NGO representatives who have accompanied and been critically engaged with the development of forensic DNA databases, as well as the implementation of innovative and controversial genetic technologies in the criminal justice system. The NGOs in question have stakes in specific public issues involving the use of genetics within security policies, police activities, and in the realm of criminal courts. We aim to understand how these NGOs self-definition

DOI: $10.4324 / 9780429261435-7$ 
regarding their own goals and functions relate to meanings, value and power structures of forensic DNA databases and innovative forensic genetic technologies. This analysis was based on 11 interviews conducted between 2016 and 2019 with NGO representatives from different European countries. The selection of NGOs and representatives in question was based upon a review of public reports on forensic genetics and state surveillance, as well as news coverage on these subjects.

The issues guiding our investigation seek to answer the following questions: what is the role and mission of NGOs regarding the development and expansion of forensic DNA databases and innovations in forensic genetic technologies? From NGOs' standpoint, what are the main issues at stake regarding the use of genetics in criminal justice? What do NGOs perceive to be the main risks and potential threats to human rights? From their perspective, which publics are most affected by the expansion of the said technologies?

NGOs have reacted critically to the expansion of "genetic surveillance," defined by Robin Williams and Matthias Wienroth as the process by which the expansion of forensic DNA databases and forensic genetic technologies enable "new forms of biological surveillance of citizens, residents, visitors, migrants" (Williams \& Wienroth, 2017, p. 6). According to the authors, the main points of controversy identified by NGOs regarding the collection and use of human genetic material for control of criminality are: first, the increased surveillance of citizens, as well as questions about which agencies will have access to DNA samples and profiles and for what purposes; second, enthusiasm for the increasing size and scope of forensic DNA databases, and optimistic public expectations around emergent forensic DNA technologies suggesting that these tools are an easily available solution to enhance public security; and third, the problems of governance of forensic DNA profiling and databasing, in light of lack of transparency and accountability aggravated by the restricted participation of non-police actors in policy and decision-making (Williams \& Wienroth, 2017)

NGOs in several European countries have, therefore, brought the debate to the public sphere and directly questioned their respective countries' governments about the risks generated by the expansive growth of genetic databases and the increasing use of other genetic technologies in criminal investigation procedures and policing activities. In terms of general trends, NGOs defend a deep change in state genetic surveillance practices targeting criminalized or especially vulnerable populations, emphasizing the need to build in regulatory and legal measures that might ensure data protection of human genetic data and guarantee the preservation of human dignity and civil freedoms. Among many other aspects, their policy ambitions have, in the words of Williams and Wienroth, focused on:

The establishment, exercise, and monitoring of powers necessary for the effective and ethical collection and use of such materials, and the balance 
between the state use of these powers and the rights - to autonomy, liberty, privacy, and justice - of individual subjects.

(Williams \& Wienroth, 2017, p. 6)

Despite academic, social, and political acknowledgement of the role played by some of these organizations, ${ }^{1}$ few empirical investigations from the branch of the social sciences have explored how NGOs construe their role and action in the domain of governance of ethical, legal and social aspects of forensic DNA databases and forensic genetic technologies (for an exception, see Samuel \& Prainsack, 2019). This chapter aims to contribute towards expanding knowledge on this topic through an analysis of interviews with NGO representatives, as relevant stakeholders in the area of forensic genetic technologies, using the definition advanced by Marina Micheli and colleagues (2020) in the following terms: stakeholders are all actors, such as individuals, organizations, and groups, who are affected by, or have an effect on, the way in which data is governed and the value that is created from it. Stakeholders differ widely in terms of the possibilities to access, control, and process data, as well as knowledge about how data is collected and treated (Micheli et al., 2020, p. 5).

Understanding how NGOs construe their own role in the ethical, social, and political debate around the risks of genetic surveillance requires building an analytical repertoire that is apt to map multiple views which are contingent as well as historically and socially situated. In this chapter we anchor our analysis on the notion of "data politics" (Bigo, Isin, \& Ruppert, 2019; Ruppert, Isin, \& Bigo, 2017). Data politics recognizes the performative power of data as a force for generating new forms of power relations (Machado \& Granja, 2020), and also draws attention to the mutability of data, illuminating how they are adapted to different purposes by diverse stakeholders (Bates, Lin, \& Goodale, 2016; Leonelli, 2016). Data politics also allows approaching data as an "object of investment," produced by the social actors and organizations claiming a stake in its meanings and functioning (Ruppert et al., 2017, p. 5). Considering such a framework, we consider the views and actions of different stakeholders on the governance of data as a heterogeneous, relational, situated, and contingent instantiation of stakeholders' roles, their goals, and the values guiding their actions, as well as the mechanisms they use to address ethical and societal challenges so as to adopt a responsible approach to data (Micheli et al., 2020, pp. 3-6). In addition, we draw on the work of Davide Beraldo and Stefania Millan - namely their exploration of the "contentious politics of data" (Beraldo \& Milan, 2019). The conceptualization proposed by the authors considers the "multiplicity of bottomup, transformative initiatives interfering with and/or hijacking dominant, topdown processes of datafication, by contesting existing power relations and narratives and/or by re-appropriating data practices and infrastructure for purposes distinct from the intended" (Beraldo \& Milan, 2019, p. 2)

Within such a framework, this chapter addresses how NGOs, in claiming their role and responsibility in the public debate about the use of forensic 
DNA databases and genetic technologies as an aid to criminality-related governance, adopt a contentious approach to data politics by construing genetic data as "objects of investment." We argue that the meanings attributed by NGOs to genetic data as an aid to criminal justice system activities are intended to claim spaces for acting and legitimating their intervention in the data regimes, by being active in the politics of data.

\section{The role and mission of NGOs in the field of forensic genetic technologies}

The universe of NGOs presents a significant diversity, namely, between organizations whose primary goal is to fight different forms of human rights violations caused by the uses of genetic data; organizations with a scientific focus, seeking to promote knowledge on questions raised by biometric technologies; or even government-funded but politically independent organizations whose goal is to monitor the uses of the said technologies. Our interviewees represent such diversity in terms of NGOs' mission. However, these categories are not impervious insofar as some NGOs may act on several of these fronts simultaneously or complementarily.

Acknowledging the social risks and ethical challenges raised by the use of forensic genetic technologies in criminality governance is at the heart of NGOs' activities. Thus, with the mission to become a critical voice on the expansion of state surveillance, the work of NGOs seeks to promote a (re) balance of power as it poses a threat to the rights of the "biological citizen,", emphasizing the means by which genetic technologies lead to the violation of human rights: "I would say that there is a risk of systemic violation of rights" (Interview G07). By constructing genetic data as "objects of investment" (Ruppert et al., 2017, p. 5), the work of NGOs, therefore, places a significant focus on the connections between ethical questions associated with the uses and expansion of biometric surveillance technologies and human rights issues, as illustrated in the following excerpt:

Our role is also to view the ethical approach through the lenses of human rights, to make it more rooted in the European charter of fundamental rights, and to somehow combine the ethical and bioethics discourse with the human rights discourse, because they often talk about the same issues but seem still a bit separate worlds.

(Interview G07)

The role of NGOs in promoting civic education on issues of science and technology and the stimulating information exchange regarding the social and moral dilemmas accompanying technological change in the field of forensic genetics, was also frequently emphasized by interviewees. Generally speaking, our interlocutors underlined the fact that their intervention is based on providing a critical questioning of technological developments that might intrude 
upon the privacy of civic freedoms, thus stimulating public interest on the nature and implications of said developments, as expressed by one of the interviewees.

Our aim is to ensure that genetics is used in the public interest, and that's by trying to give people a say about genetic technologies and the impacts on them (...). So all (...) to take a perspective that is focused on preserve human rights. And so, we're looking out at the use of these technologies in that perspective.

(Interview D05)

On this point, the following interview excerpt illustrates NGOs concern with promoting trust building initiatives with the aim to provide the public with transparent information about the risks of forensic genetic technologies and to engage with social movements claiming for stricter and more transparent control over data protection issues as a means to protect citizens from abusive uses of state surveillance:

We try to provide critical, commented and interpreted information on genetic developments to the public, and to explain the implications for society. We also engage in specific campaigns, specific petitions with social movements on these topics. Because the first step is transparent information, not only about scientific and technological developments, but also their implications on society, which power structures are they embedded in, which implications do they have for change in society.

(Interview O03)

Another domain of intervention claimed by interviewees for NGO activity is the promotion of a democratic engagement of affected publics in the scrutiny of genetic data uses for criminal investigation purposes. Democratic engagement might imply taking the discussion of surveillance-related issues to a wider public debate, enabling a model of decision-making that aspires to a collective political movement that can articulate different agendas and specific interests (Amelung \& Machado, 2019). Such initiatives illustrate a contentious approach to the data politics, inasmuch as citizens and civil society entities are becoming increasingly aware of the issues at stake, as well as of the opportunities for democratic empowerment embodied in data practices (Beraldo \& Milan, 2019, p. 4). In the words of the following interviewee, NGOs should mobilize not only citizens, but also (and primarily) professionals and organizations from different fields, whose cooperation can generate a broader social impact:

... [our] aim is to provide news and information, and analysis and research, on developments in relation to the law and the powers and policies of state agencies, in order to inform the activities and responses of society at large, or journalists, lawyers, students, advocacy groups and 
so on, within our various areas of interest, such as policing, or migration, police surveillance, criminal law, agencies and so on.

(Interview D16)

The model of political participation, engaged with public decision-makers, is also an ambition for NGOs of a more institutional character and with a more permanent presence in the public sphere, interacting with scientists, humanrights experts, and political actors both nationally and transnationally. Although these kinds of NGOs have a strong monitoring and advisory role, in some cases, as one of our interviewees pointed out referring to the NGO where he/she works and which is partially government-financed, their role is also to embody and create the conditions for national jurisdictions to comply with international directives on human rights. The following excerpt, therefore, highlights the central role of mediation between transnational and national political actors:

Virtually all Member States of the United Nations were asked by the general assembly to install a so-called national human rights institution, which basically has this special role of monitoring the implementation status of the new international human rights convention in the Member States. We are not just doing monitoring I would say, but we also take an advisory role for politics in order to further the protection and advancement of human rights in our country.

(Interview O12)

Inspired by the work of Marina Micheli and colleagues (2020), we outline on table 7.1 the main characterizing features of NGOs regarding forensic DNA databases and forensic genetic technologies, including their fields of action, goals, values, mechanisms and procedures. Within this framework, goals are conceived as "value-based objectives established by different stakeholders for governing data" (Micheli et al., 2020, p. 5).

In the context of NGOs' self-description of their roles in the field of forensic genetic technologies, goals range from a critique of state surveillance aimed at (re)balancing power in terms of the threats posed on the rights of the "biological citizen," to informing the public about science and technology innovations and adopting a responsible approach to genetic data. Values refer to the expected results (Micheli et al., 2020) which, in the case of NGOs claiming to have a role and responsibility in the domain of public debates about genetic surveillance, reflect upon the protection of human rights, the democratic engagement of decision-makers and affected publics, and the promotion of transparency and accountability. Finally, by mechanisms and procedures we understand the "the strategies and instruments adopted by different agents to achieve their goals and direct change in a socio-technical system" (Micheli et al., 2020, p. 5). Concerning the theme in point, mechanisms include watchdog actions, trust-building initiatives, co-construction of decision-making policies, and taking on monitoring and advisory roles. 
Table 7.1 Summary of NGOs' role and mission in the field of forensic genetic technologies

\begin{tabular}{llll}
\hline Field of action & Goals & Values & $\begin{array}{l}\text { Procedures/ } \\
\text { Mechanisms }\end{array}$ \\
\hline $\begin{array}{l}\text { Human rights } \\
\text { activism }\end{array}$ & $\begin{array}{l}\text { Critique of state } \\
\text { surveillance } \\
\text { Rebalance power } \\
\text { that threatens } \\
\text { the rights of the } \\
\text { "biological } \\
\text { citizen" }\end{array}$ & $\begin{array}{l}\text { Protection of } \\
\text { human rights }\end{array}$ & Watchdog actions \\
& $\begin{array}{l}\text { Inform the } \\
\text { public about } \\
\text { science and } \\
\text { technology } \\
\text { innovations }\end{array}$ & $\begin{array}{l}\text { Instigate demo- } \\
\text { cratic engagement } \\
\text { of decision-makers } \\
\text { and affected } \\
\text { publics }\end{array}$ & $\begin{array}{l}\text { Trust building } \\
\text { initiatives } \\
\text { Co-construction of } \\
\text { decision-making } \\
\text { policies }\end{array}$ \\
$\begin{array}{l}\text { educational } \\
\text { organizations }\end{array}$ & $\begin{array}{l}\text { Adible approach to } \\
\text { genetic data }\end{array}$ & $\begin{array}{l}\text { Promote transpar- } \\
\text { ency and } \\
\text { accountability }\end{array}$ & $\begin{array}{l}\text { Monitoring and } \\
\text { advisory role } \\
\text { Mediation between } \\
\text { transnational and }\end{array}$ \\
$\begin{array}{l}\text { Government-funded politically } \\
\text { independent } \\
\text { organizations }\end{array}$ & $\begin{array}{l}\text { national political } \\
\text { actors }\end{array}$ \\
\hline
\end{tabular}

Source: Authors, inspired by Micheli et al. (2020).

As previously explained, according to the analytical repertoire adopted in this chapter, focused on understanding our interlocutors' narratives in the light of the concept of data politics (Bigo et al., 2019), the views and actions of NGOs constitute a heterogeneous, relational, situated, and contingent instantiation. The meanings and significance attributed to their goals, to the values guiding their actions and to the mechanisms used to address ethical and societal challenges, thus serve as spaces of public visibility and legitimation. In other words, and as the next section of the chapter will describe, this self-reflection of NGOs about their place and impact on society relates to the broader prevailing cultural, political, historical, ethical, and economic context resulting from a mediation between the transnational sphere and the local and national levels at which particular NGOs operate.

\section{Diversity of non-governmental organizations within Europe}

By conducting interviews with representatives of NGOs that operate in different European countries, some of which are part of international networks, it is very clear how the diversity of historical and political trajectories of forensic genetics within the European context affects the role and impact of NGOs (Amelung \& Machado, 2019). Such a differentiated impact is also influenced by the heterogeneity, within the European context (Amelung, 
Granja \& Machado, 2020), of political and democratic regimes with varied and complex implications on assertions about social order, affirmations of common values and civil rights, and promises about security and justice (Wienroth, Morling \& Williams, 2014).

An empirical case that is especially revealing of the NGOs visibility in terms of the social and ethical challenges posed by forensic technologies is the United Kingdom. The UK's National criminal Intelligence DNA Database (the oldest DNA database in the world) is an illustrative example of how expanding the criteria for collecting and storing DNA data in a database for criminal identification purposes might generate public controversies and instigate worries about threats to human rights and civil liberties (Amankwaa, 2018; Williams \& Johnson, 2008). The expansion of the forensic DNA database in the UK, which ultimately led to the creation of the largest databases in the world, brought about what has become known as an example of "maximum surveillance society" conceived to put a discrete population of "active criminals" in a "closed circuit" of surveillance (Williams \& Johnson, 2004). In light of this scenario, several civil society groups and NGOs have campaigned against the expansion of genetic surveillance, defending the protection of human rights and echoing demands for more civic accountability (Amelung \& Machado, 2019; Wilson-Kovacs, Wyatt, \& Hauskeller, 2012). Previous studies based on the UK context have equated NGOs construing of their role and place in the public arena as processes that have accompanied the historical development of the UK's national DNA database throughout. The UK's example, therefore, was mentioned by our interviewees as an emblematic instance of a consolidated presence in the public sphere of diverse NGOs. These organizations dedicate their activity to denouncing state surveillance activities, while also potentially defending quite different courses of action, agendas, and interests. In the words of one interviewee:

In the UK specifically, there is a whole range of different organizations concerned with state and corporate surveillance, with different sort of political agendas or alignments, more or less radical, more or less media friendly, and sometimes they do things wrong and sometimes they do not.

(Interview D16)

In a different situation, although equally embedded in the specificity of their national contexts, our interviewees also pointed out the complex and particularly visible challenges posed on NGOs dealing with human rights in European countries with a recent legacy of dictatorial and oppressive regimes. In these contexts, the role of NGOs that address genetics and biotechnologyrelated issues from a human rights perspective is looked upon with suspicion by some state agencies. One of our interviewees mentioned the tensions generated by the NGO' work, given that since their activity depended on international collaborations, it seemed to arouse more suspicions, for fear that it might reflect upon and put into question the reputation of national police 
agencies and government. According to this testimony, mistrust of NGOs working at an international level is an endemic problem to former communist eastern European countries:

Every organization which receives foreign funding is [in former communist countries in Europe] considered a "foreign agent," which sounds almost as a spy (...) The cooperation with international organizations is also treated as treason. NGOs are accused that they are ruining the reputation of the country by preparing reports on human rights abuses and talking to people outside national jurisdiction (...) the next step will probably be to limit the activities of NGOs.

(Interview G07)

Acknowledging that the context in which an NGO operates strongly influences the latitude of a contentious politics of data (Beraldo \& Milan, 2019), therefore becomes a crucial matter. While in some contexts, with a long history of contestation, there is place for an ample diversity of NGOs to operate with different roles and missions, in contexts marked by an endemic suspicion and mistrust, the possibility for action is faced with enormous obstacles. The following sections of this chapter will explore NGOs' constructions and definitions of roles, missions, and spheres of action from the perspective of social actors who are members of these organizations, looking out especially for critical views about the expansion of genetic surveillance and subsequent exacerbation of discrimination over specific groups that are more susceptible to criminalization.

\section{Critique of the current landscape of genetic surveillance}

\section{Expansion of genetic surveillance}

The starting point for NGO action is the trend of genetic surveillance expansion, generally accompanied by a generally enthusiastic public acceptance. At an initial stage, the tendency in most countries is to create genetic databases following strict criteria of DNA profile collection and storage (for example, limiting data to the collection of genetic profiles of serious crime offenders). However, subsequent developments tend to give rise to changes in the criteria, leading, for instance, to include suspects and persons convicted for crimes considered less serious. This movement of loosening the criteria of collection might result in the disproportionate expansion of database size, with implications for thousands of people. Several of our interviewees commented on the fact that legislative changes to increase genetic surveillance through DNA profile criminal databases and other biometric databases tend to occur in political atmospheres that instill fear of crime and threats to collective security. In the following excerpt, one of our interviewees characterizes such a phenomenon occurring at the level of the European Union on the 
whole, referring the lack of democratic debate, whose importance is obscured by "feelings of urgency":

The proposals [for changing legislation] are all introduced in a language in terms of crisis and urgency and the need to do things very quickly, which means that things may not be done very well. The EU legislative process is already extremely flawed from a democratic perspective. Proposing to introduce new methods of biometric data collection and storage at that level, and collection of data from more people, without making sure that there is time for all considerations and debates, with magistrates being pressured all the time by this sense of urgency and crisis, is potentially very problematic. And also unhealthy in what is supposed to be a democratic system.

(Interview D16)

The situated cultural embedding of technology and innovation influences the public acceptance, ethics and accountability of innovations (Bowman, Stokes, \& Rip, 2017; Pfotenhauer \& Jasanoff, 2017; Rip, 2017). The concept of "imaginaries of innovation" proposed by Pfotenhauer and Jasanoff (2017), allows us to deconstruct the almost omnipresent rhetoric of technological innovation and to map the cultural and political elements surrounding trajectories of innovation. The authors explore, on the one hand, the culturally distinct collective "self-diagnosis" of current societal problems and the understandings of why a particular innovation is needed and perceived as a "cure"; on the other hand, which social and institutional changes and reactions would be acceptable in this context. In the case of our current analysis, we would say that the diagnosis made by NGO representatives is that of a society tending to express enthusiasm over the expansion of databases and forensic genetic technologies for criminal investigation purposes. The reasons for this to happen are diverse: from the influence of media on public in general, as well as political decision-makers' enthusiasm with the potential of DNA technologies to solve crime problems.

Media influence on the expansion of genetic surveillance takes pride of place in the narratives of participants in this study. Members of NGOs consider the media to convey an inaccurate portrayal of DNA technologies. By exaggerating the possibilities, the speed and the outcomes of DNA technologies in solving crimes and enhancing public security, media narratives are perceived by NGOs representatives as failing to provide a comprehensive description of the inherent risks of genetic technologies. Such a portrayal implies that critical perspectives on the implications of such technologies, anchored in the defense of human right protection, are absent from mediaconstructed narratives, as one participants manifests:

The public debate connect[s] very simply to the politics and the desires of the security (...) without developing any critical reporting on their own. 
(...) Data protection, questions about civil rights and the constitutional state don't play any role at all, neither does exact information regarding the scientific foundation, the technical foundation.

(Interview O03)

The general public is considered by interviewees to be highly susceptible to media influence, usually portraying DNA technologies as infallible (Amelung et al., 2020; Cole \& Dioso-Villa, 2009). In the words of one interviewee, the public's enthusiasm with technologies such as genetic profiling reflects a prevalent trend in popular culture of the idea that the identification of persons through DNA provides a kind of "truth machine" (Lynch et al., 2008):

What I feel is that the general public (...) they think that DNA is gold. As soon as DNA is found on a crime scene, you can solve the issue because DNA will prove who has done it. I think that this is why it is a bit problematic, a lot of people do not know that DNA is not as easy as saying. So, I think there is a big gap in information in the general public as to the usefulness of DNA and the risks that DNA profiles carry with them (...) this is why the debate issues lead in the direction if we need to have more of these DNA profiles, because it will become easier to solve cases.

(Interview A11)

Besides adopting a critical stance on how the media portray genetic technologies used for criminal investigation purposes, influencing the public to favour its expansion, interviewees also highlight the role of media in some legislative changing processes. Specifically, they point out how these agents set the ground for the expansion of genetic surveillance by exploring prominent criminal cases that attract high public attention (Jong \& M'charek, 2017; M'charek, Toom \& Jong, 2020; Machado \& Santos, 2009, 2011) - see also Chapter 5. One of the interviewed persons described the enormous media pressure felt in the wake of certain high profile criminal cases, which influenced the government to ponder introducing changes in legislation to increase the number of individuals whose genetic profile should be included in the forensic database.

[There were two high-profile criminal cases] that caused quite a bit of a stir in my country, and the public debate was generally one: that everyone should provide their DNA to solve these cases. There was not a lot of counterbalancing, at least not from within society.

(Interview A11)

Criminal cases that attract great public attention have thus played, in several countries, a central role in legitimizing the creation and expansion of forensic genetic databases and/or the introduction of controversial genetic technologies. Garnering emotional support from the public by nurturing 
compassion and sympathy for the victims as well as feelings of moral repulsion against offenders (Machado \& Santos, 2009), genetic technologies are portrayed by the media as responding to public needs of security and justice, thus attenuating (or obscuring) its risks. Consequently, such criminal cases create a context in which the general public appears to be largely in favour of expanding different forms of genetic surveillance and politicians appear favourable to legislative changes. This potential to influence public opinion and the legislative framework, generates apprehension and concern among NGO representatives, as the following interviewees attest:

"But what's so bad of that if you catch the bad people with it?" And this is the perception of many, many people in the society (...) the police is very much making use of highlighting crime cases. (...) I mean, there's nothing in the media about all the risks or the problems with that.

(Interview O04)

I think that in practice the media would put something on the agenda, so if there is a big case, for example, then suddenly everyone thinks it is important and the parliamentarians would start running and yelling that something needs to be done. So, the media is, almost always, the one who puts something on the agenda.

(Interview A11)

Media discourse that conveys unrealistic and inflated views on potential contributions of DNA analysis to criminal investigation processes, coupled with the general public and politicians' enthusiastic responses are, therefore, considered by all interviewees to be the main reasons for the general trend of public acceptance of genetic surveillance expansion. Several academic studies in the fields of the social sciences socio-legal studies confirm that these trends of public acceptance of genetic database expansion and other forensic genetic technologies (Amankwaa, 2018; Machado \& Silva, 2014, 2016, 2019), resulting from the alliance of state and law enforcement agencies with some sectors of the scientific community and the media, curtails the space for visible critical action and public awareness campaigns on the risks of these technologies. Thus, the adoption of a "contentious politics of data," seeking to question relations of power and reappropriate data practices and infrastructures (Beraldo \& Milan, 2019), is made enormously difficult. The following excerpts exemplify the opinion of interviewees on this point:

It is becoming increasingly difficult to defend the idea that you want the DNA profiles to be limited or at least the DNA database to be limited.

(Interview A11)

Of course we are, as an NGO, or human rights activists or lawyers, we are concerned about state surveillance and express that concern. And we 
gather some support for that, but the fact that those bills are being adopted without a huge public outcry would suggest that the concerns are not as big as ours, and that in the end the people are convinced that it is for their own safety and that the reasons of security outweigh the privacy concerns.

(Interview G07)

The notion that the general public responds enthusiastically (or otherwise indifferently) to DNA profile databases and forensic genetic technologies, has been explained as a trend associated with cultural and social processes of differentiation between law-abiding citizens and criminal offenders. As Helena Machado and Susana Silva (2016) put it, in connection to public surveys and opinion polls about the acceptance of DNA profile database expansion:

(...) the application of genetic technologies in the field of forensic criminal investigation is viewed as having important implications in terms of labelling the moral status of individuals, distinguishing, for example, between criminal suspects and "non-suspects." These classifications are also associated with the hierarchies of trust placed in judicial and scientific institutions, differentiating between the fears of dangers and the collective and individual expectations of the potential benefits.

(Machado \& Silva, 2016, p. 337)

In this context, the enthusiasm for DNA technologies and the acceptance of genetic technology expansion and development might be questioned from the moment the public is confronted with the effacement of differences between non-suspect populations and criminals. The case of UK's DNA profile databases has been frequently mentioned by interviewees as a notorious example of such tensions. According to one of our interviewees, the initial stages of creating a forensic genetic database in the UK did not arouse much controversy or public debate (Downey, Stephens, \& Flaherty, 2012). However, as the criteria of collection and storage of profiles were broadened, allowing the genetic data of suspects or even children to be stored permanently, the database problem was no longer viewed by the public as something that only concerned individuals who had committed crimes. From the moment people felt implicated in the network of suspicion, society at large began to find this concerning development to deserve its attention (Skinner \& Wienroth, 2019). In the opinion of the following interviewee, the fact that people began to feel themselves and their families being enmeshed in the web of suspicion, led to an engagement with this problem unseen thus far:

In the UK what happened is because ordinary people started being caught up in the system, particularly children, because there was a push at the same time to tackle anti-social behaviour and arrest children for very minor offences. Then you did get ordinary people on the streets that 
were engaged in the debate, and you know, actually talking about that kind of thing... But that's quite unusual, and I think it did result from the fact the people's own families were affected, or they knew people... We've reached a state where most people knew somebody whose child or themselves were on the database. Perhaps that is not normally the case; normally you're seeing other people, you know, criminals that's real criminals, so that is a good thing, so... I think there is an issue of how to engage people in the debate if they don't feel they are going to be affected personally.

(Interview D05)

Notwithstanding the existence of some manifestations among the general public against the inordinate expansion of genetic databases, as in the UK's example, there is a relatively uniform tendency favouring the expansion of genetic surveillance throughout European countries. Such a tendency substantiates what previous literature had called the expected development of a "logic of convergence" (Hindmarsh \& Prainsack, 2010; Machado \& Silva, 2009) under which the growth in scope of all national databases, constituting an ever-widening population of genetic suspects, is assumed as an inevitable outcome. Some of our interlocutors even referred to the creation of universal databases (including the genetic profiles of the whole population) in nonEuropean contexts (Wallace et al., 2014), showing their concern with this phenomenon:

The moment when basically entire parts of the population or the entire population is being captured indiscriminately, entire new questions emerge. When you look at what is happening in Saudi Arabia or partly also in China where indeed the entire population is recorded genetically there we don't just have a problem of discrimination, there we have a general problem of state surveillance, meaning that at any point you can be controlled, monitored, identified, accused, prosecuted and so on.

(Interview O07)

Another domain identified by interviewees as highly conducive towards a logic of convergence is connected to the power of industries and lobbies interested in expanding the forensic genetics market. From the point of view of NGO representatives, the expansion of increasingly integrated genetic surveillance systems reflects market interest in expanding and make databases more and more interoperable. The following interview excerpts underline how NGO representatives interpret the commercial and political interests underlying the design of security policies generally associated with concerns about terrorism and crime fighting in Europe. From the standpoint of our interviewees, this expansion results from a strategic confluence between the commercial and economic interests of IT corporations, security and law-enforcement agencies, and political decision-makers. 
The plans for interoperability of databases [involve intensively] industry expertise (...) contracting from transnational IT and technology corporations (...) My hunch is that one of the main drivers for the process leading to interoperability is that the industry has told to a lot of public officials: "This is great, you should do it, and we can do it for you. And it will be easy, do not worry about that." So, most times it is more than just a sort of technocratic management agency, it also has a political stuff in advocating for interoperability proposals and various other measures.

(Interview D16)

Some countries and some industry players were like pushing projects for the whole EU (...). The idea was having a project among some Member States where it's easy to install and easy to get running, and then you can explain it as "Look, how successful we have this exchange. Let other countries connect. Why don't we make European system of legislation on that?"

(Interview O04)

Despite these developments in genetic surveillance towards a logic of convergence, genetic surveillance's greatest impact is still undeniably directed at individuals and groups considered high-risk (Williams \& Johnson, 2004). The next section of this chapter will explore how NGO representatives give meaning to processes of social, ethical, and racial discrimination of particular social groups. This is one of the main aspects of how NGOs working in the domain of human rights and data protection and privacy safeguards view the perceptions and development of public concerns related to criminal DNA databases and innovations in forensic genetic technologies. In other words, NGOs' recognition of a positive and enthusiastic "public" reception of genetic databases does not preclude a "contentious politics of data" (Beraldo \& Milan, 2019) that outlines the need to identify and acknowledge public problems and risks affecting particular groups more directly and acutely.

As mentioned at the beginning of this chapter, our approach to the "data politics" performed by NGOs implies interpreting interviewees' narratives as a situational and relational study object. Thus, we find that our conceptual repertoire gains by incorporating Nina Amelung and Helena Machado's (2019) argument as to the need to go beyond conventional approaches to public understanding of forensic genetics. The authors propose, in the wake of authors such as Noortje Marres (2005) and Mike Michael (2009), focusing on how collective issues create publics in the domain of forensic genetics, namely by mobilizing people who are indirectly and seriously affected, forming a distinctive enough group to require recognition. In light of this, the next section of this chapter will analyse NGOs' views on a group of publics construed as especially problematic, owing to their acute vulnerability to forensic genetic database surveillance, namely immigrants, refugees and racialized minorities. 


\section{Genetic surveillance and suspect communities}

"Illegal migration," "transnational organized crime" and "terrorism" have become standard political "categories of blame" (Aas, 2013). Such categories serve to legitimize rigorous and sometimes extreme measures to defend states and societies against their perceived enemies. One of the structuring characteristics of surveillance technology use, both in the ideological as in the operational and technical domain, is the growing connection between crime management, terrorism and migration policies (Aas, 2011; Ajana, 2013; Amelung et al., 2020; Amoore, 2013; Bosworth \& Guild, 2008; Broeders, 2007; M'charek, Schramm \& Skinner, 2014; Skinner, 2018a; Tutton, Hauskeller, \& Sturdy, 2014). As shown by David Skinner, "notions of citizenship, mutual benefit and of deserving and undeserving subjects are built into the architecture and conventions of security systems" (Skinner, 2018a, p. 3). While research has shown that national DNA databases tend to reflect policing practices that usually target minorities, such as foreigners and racial monitories (Chow-White \& Duster, 2011; Duster, 2006; Skinner, 2013, 2018a), less is known about how genetic surveillance targeting migrants and other risky populations is being directed towards both justifying, implementing, and normalizing transnational networks of DNA data exchange (see Chapter 3 in this book).

Nonetheless, the narratives of NGO members interviewed for this study reveal many concerns with the growing affinity between migration and crime control, as well as with how genetic surveillance is becoming increasingly transversal across different domains of action. Interviewees find meaning in their action and mission in terms of their contribution to a public criticism of how vulnerable populations, namely migrants, refugees, and racialized minorities, become the primary targets of genetic surveillance and are amalgamated into the category of "suspect communities." Following Christina Pantazis and Simon Pemberton's proposal, we adopt the concept of "suspect community" as referring to:

A sub-group of the population that is singled out for state attention as being "problematic." Specifically, in terms of policing, individuals may be targeted, not necessarily as a result of suspected wrongdoing, but simply because of their presumed membership to that sub-group.

(Pantazis \& Pemberton, 2009, p. 649)

In the words of the following interviewees, migrants are prominent examples of "suspect communities" in the eyes of police agencies and state surveillance. In their view, there is a systemic pattern of discrimination and prejudice towards these social groups, which projects and reinforces stereotypes according to which certain communities are considered particularly prone to commit crimes. This process occurs within a setting where human rights and privacy protection are suspended and police action operates without control or constraint of potential human-right abuses: 
The idea that migrants are more likely to commit crimes or more susceptible to becoming criminals, or alternatively that because there is information available the police should have access to it, but without certain safeguards and provisions, but that is still sort of the basic principle underlying giving them access to it. (...) In the case of the migration, asylum databases, it seems to me they are designed to implement policies which in many cases are extremely harmful...

(Interview D16)

With regards to non-national citizens it is the Wild West, the police can do whatever they want.

(Interview G07)

The heightened vulnerability of migrant groups to state and police surveillance based on biometric systems (whether DNA profiles or any other kind of biometric data technology, such as facial recognition or fingerprinting) is also sharply summed up in the following interview passage, which refers to how technological innovations tend to be initially tested on migrant populations:

I am quite right to say, that migrants are guinea pigs for introducing more surveillance capacity in the European Union (...) the purpose of the government is to collect as many data about migrants because they are one of the biggest receiving countries.

(Interview O04)

Therefore, all interviewees recognized the dramatically expanded DNA surveillance of migrants through which many countries collect DNA from immigration detainees and store their genetic information in the respective national database (Aas, 2011; Makhlouf, 2020; Tutton et al., 2014). The following excerpt also reveals the ethically troubling nature of the expansion of DNA surveillance of immigrants since no oversight mechanisms are in place to address the potential privacy harms that it creates.

We need to be sure that all that information technology including taking DNA from migrants is used in a responsible way (...). Is the system built in such a way that people can take responsibility? Can they access the information?

(Interview A10)

Suspect communities, including immigrant and refugee groups, are therefore part of a collective modality of suspicion that very clearly affects groups and populations which are more liable to the discretionary power of the criminal justice system. Considering the substantial opacity enfolding state surveillance practices, representatives of NGOs call for the need to implement regulation frameworks and mechanisms of oversight capable of producing 
accountability and transparency. As outlined by the following interviewee, the publication of bulk statistics is insufficient to grasp the complexities of how data is being collected and used, or how it discriminates between different groups.

I know that what they are only required to do is provide like bulk statistics, and in a way gives opportunity to control how this is performed. With how they access data, I would say no, there is no information (...) But the law, as far as I know, does not create the obligation for the agencies to report publicly, to create some kind of transparency report of what they are doing with regards to data collection.

(Interview G07)

Besides calling for the need to implement oversight mechanisms in pre-established surveillance practices, the narratives of NGO representatives also express the need to adopt an approach to data politics that critically addresses innovative genetic technologies at a research and development stage, considering its potential to consolidate stigmatization and discrimination of certain suspect communities. This is what Matthias Wienroth calls "anticipatory governance deliberations," which mobilize the promise of the new technological capabilities, while managing expectations about its operational, epistemic, and legal dimensions (Wienroth, 2018).

\section{Racialized genetic surveillance}

Coupled with the growing surveillance over refugees and immigrants through preestablished systems of transnational data collection and exchange, we also witness the development of forensic genetic technologies, which find favourable conditions for their implementation and legitimation in the dominant rhetoric about the fight against crime. A particularly illustrative example of how a technology might be linked with systemic modes of discrimination is forensic DNA phenotyping (FDP) (see Chapter 6 in this book), a constellation of techniques that infer physical features, such as eye, skin and hair colour, as well as information about biogeographic ancestry, from biological samples found at crime-scenes (Granja \& Machado, 2020; Granja, Machado, \& Queirós, 2020; Wienroth, 2018). Considering how FDP is directly related to racialization (M'charek et al., 2020; Queirós, 2019; Skinner, 2018b), since it produces inferences about the racial or ethnic appearance of as yet unknown suspects, most interviewees tend to adopt a very critical view of it, underlining its potential to consolidate racial discrimination. As straightforward enunciated by one of the interviewees:

I think that with phenotyping the danger of racist discrimination is increasing enormously.

(Interview O12)

From the point of view of our interviewees, in assessing the risks associated with FDP, two main elements must be taken into consideration, which in turn 
are linked with two distant stages of a technology's social life (Kruse, 2016), namely, its development and implementation. Regarding the development of FDP, interviewees outline how this technology relies on a computerized comparison that uses reference databases with variable composition, representativeness and organization. This implies that results are based upon cohort biases (Granja et al., 2020; Skinner, 2018b), which raises doubts about its reliability. This perspective is illustrated by the following interviewee:

These databases which are necessary for it, and also the collection of data from the population which is necessary for it, that they alone constitute discrimination against people by their looks or even their origin, which is very closely linked to a danger of racist discrimination.

(Interview O03)

In addition, NGO representatives outline the risks associated with the fact that FDP is anchored on probabilistic statistics (Hopman \& M'charek, 2020). The implications are two-fold: first, there is certain degree of uncertainty associated with the interpretation of forensic DNA technologies that must be considered and managed in the use of FDP in criminal cases. Second, the results of FDP cannot be communicated as a definitive certainty. Instead, they are communicated as a score of a threshold of probabilistic accuracy about each physical feature (Granja et al., 2020). According to one of the participants, FDP therefore constitutes "an unfinished technology," which presents severe risks deriving from their potential to shed suspicion over a certain group or individual.

The risk that a lot of information is that an unfinished technology misinterprets probabilities, not with regard to the real population but with regard to the probability of predictions; that there could be many wrong suspicions.

(Interview O03)

Besides expressing concerns over technical issues in FDP, NGO representatives also point out how this technology raises implementation-related issues. More specifically, interviewees outline how this technology might relate to preexisting discretionary practices in police activity, associated with institutional racism. By indicating that a given suspect is from a particular suspect community, FDP holds the potential to further consolidate pre-existing discriminatory practices. This perspective is illustrated by the following interviewee:

We would say that especially those expanded DNA analyses are highly sensitive to connections with discrimination and racist associations, so therefore we would be fundamentally against them. (...) In the daily police practices there are currently many open questions regarding institutional racism. 
Such perspectives thereby shed light on what David Skinner terms "race datafication" to explain how "data do not speak for itself: we should appreciate the processes by which it is brought to light, organized, and interpreted - that is, turned into racialized information" (Skinner, 2018b, p. 7). The creation of racialized suspect communities through FDP implies translations between different contexts (laboratory, police station, media, and community) (see Kruse, 2016), in which data will be re-interpreted differently according to the context. According to the following interviewee, by enhancing the racialized character of potential suspects, FDP thus ends up concentrating attentions on crimes whose suspects are racialized.

So we are not just saying in sweeping generalizations that this is all racism, but we are saying that we see that ethnicity, geographical origin and the expected looks, phenotypic associations, which then is directly racialized, are directly combined. (...) Certain acts of violence are only in the public eye at the moment if refugees or people with migration background are suspected to be the culprits.

(Interview O03)

As observed by David Skinner, "creating racialized suspect populations thus potentially generates a double disadvantage, by directing suspicion towards members of minorities and by inviting further group stigmatization by association" (Skinner, 2018b, p. 18). In considering the contingencies associated to the technology, as well as the social context in which it is embedded, characterized by structured inequalities linked to discrimination and stigmatization of racial and ethnic groups, representatives of NGOs therefore generally oppose the use of FDP without a strictly regulated framework. By doing so, NGOs claim spaces for action and legitimation to intervene in the data regimes, by being active in the politics of data (see Table 7.2).

Table 7.2 Modes of data politics

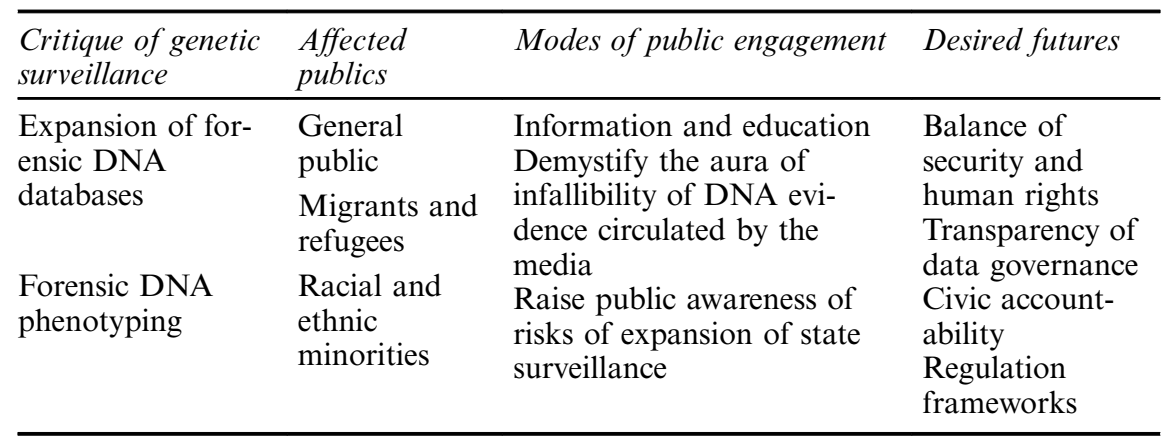

Source: Authors. 


\section{Conclusion}

In this chapter we aimed to explore the views of NGO representatives based in Europe who follow and engage critically with the development of forensic DNA databases and the application of innovative and controversial genetic technologies in the criminal justice system. Following Didier Bigo, Engin Isin, and Evelyn Ruppert (2019) we consider data politics to generate new forms of power and knowledge that reconfigure relationships between subjects and citizens. Following this premise, genetic data was approached as an "object of investment," in whose meanings and functioning NGOs claim a stake (Ruppert et al., 2017, p. 5), thus carving out spaces of public visibility and legitimation.

While addressing how NGOs perceive their role and mission in the field of forensic genetic technologies, it is clear that, despite internal diversity and differentiated national contexts, the main aims of NGOs associated with the use of genetics within security policies, police activities, and in the realm of criminal courts, are oriented towards a critique of the expansion of genetic surveillance as a means to rebalance the power threatening the rights of the "biological citizen." Informing the public about science and technology innovations, as well as enforcing the adoption of a responsible approach to genetic data are also considered essential pillars of their mission. However, the possibility to act on such ideals is not the same across Europe. While some NGOs operate in contexts whose historical, social and political trajectory promote public debate and facilitate public visibility of critical perspectives that counterbalance the indiscriminate expansion of genetic surveillance, other contexts are characterized by atmospheres of suspicion which hinder such initiatives. This demonstrates the situated and contingent nature of NGOs' role and mission, inasmuch as they relate to the broader historical, social-political, and economic principles embedded in each country's specific contexts and infrastructures.

As we address the current landscape of forensic genetics, it is clear that NGO representatives find that critical responses to the expansion of genetic surveillance have been largely confined within specific communities of experts. Resistance to data collection and efforts to implement a social justice agendas are usually unknown to the general public and political decision-makers who, highly influenced by the media's portrayal of DNA technologies as "truth machines," (Lynch et al., 2008) are usually enthusiastic about the expansion of forensic DNA databases and/or the implementation of innovative technologies. This situation, also influenced by the omnipresent uncertainty of threats, creates an apparent necessity and justification for taking everexpanding measures. Within such a setting, high profile criminal cases, construed by the media as public dramas (Machado \& Santos, 2009), also play a significant role in gaining support for the expansion of genetic surveillance (Jong \& M'charek, 2017). According to NGO representatives, a further factor influencing the expansion of genetic surveillance significantly is the power of 
industry and lobbies with an interest in the expansion of the forensic genetics market, thus advocating in favor of expanding interoperability initiatives.

Besides engaging in a critique of the overall context of genetic surveillance expansion, NGO representatives also argue for an increased emphasis on the fact that genetic surveillance does not impact everyone equally. The potential for social sorting implied in genetic surveillance ends up affecting more acutely those groups that are more vulnerable to the action of the criminal justice system and which require particular recognition, such as migrants, refugees and racialized minorities. Being constructed as suspect communities, requiring state attention owing to the alleged risk that they pose (Pantazis \& Pemberton, 2009), such groups have an increased vulnerability to the action of state surveillance. Representatives of NGOs therefore underline that the targeted use of forensic DNA technologies upon such suspect communities ultimately reinforces patterns of inequality, by directing suspicion towards members of minorities and, therefore, inviting further group stigmatization and criminalization (Skinner, 2018b). Under these circumstances, NGOs assume the responsibility of reporting situations where there is a clear violation of human rights, claiming for the need to establish routes of transparency and accountability, as well as to accomplish "desired futures" (Jasanoff \& Kim, 2015) for the governance of innovations in forensic genetics. By creating spaces of public visibility and legitimation of their claims, NGOs attempt to construct paths towards an active engagement with data politics, thus instituting their contentious approach.

\section{Note}

1 In the UK, the NGO GeneWatch UK has been actively interrogating official statements and statistics of the UK National Criminal DNA Database, as well as appearing before several Parliamentary House of Commons Committees. In other European countries, groups like the "Campaign against DNA collection frenzy" in Germany and the Hungarian Civil Liberties Union have been very active in bringing critical standpoints related to genetic surveillance to national parliaments.

\section{References}

Aas, K.F. (2011). "Crimmigrant" bodies and bona fide travelers: surveillance, citizenship and global governance. Theoretical Criminology, 15(3), 331-346. https://doi. org/10.1177/1362480610396643.

Aas, K.F. (2013). Globalization and Crime (2nd ed.). Thousand Oaks: SAGE Publications.

Ajana, B. (2013). Governing Through Biometrics: The Biopolitics of Identity. London: Palgrave Macmillan.

Amankwaa, A.O. (2018). Forensic DNA retention: public perspective studies in the United Kingdom and around the world. Science \& Justice, 58(6), 455-464. https:// doi.org/10.1016/j.scijus.2018.05.002.

Amelung, N., Granja, R., \& Machado, H. (2020). Modes of Bio-bordering: The Hidden (Dis)integration of Europe (1st ed.). London: Palgrave Macmillan. https:// doi.org/10.1007/978-981-15-8183-0. 
Amelung, N. \& Machado, H. (2019). "Bio-bordering" processes in the EU: de-bordering and re-bordering along transnational systems of biometric database technologies. International Journal of Migration and Border Studies, 5(4), 392-408. http s://doi.org/10.1504/ijmbs.2019.105813.

Amoore, L. (2013). The Politics of Possibility: Risk and Society Beyond Probability. Durham, NC and London: Duke University Press.

Bates, J., Lin, Y.-W., \& Goodale, P. (2016). Data journeys: capturing the socio-material constitution of data objects and flows. Big Data \& Society, 3(2), 1-12. https://doi. org/10.1177/2053951716654502.

Beraldo, D. \& Milan, S. (2019). From data politics to the contentious politics of data. Big Data \& Society, 6(2), 1-11. https://doi.org/10.1177/2053951719885967.

Bigo, D., Isin, E. \& Ruppert, E. (Eds.). (2019). Data Politics: Worlds, Subjects, Right. Abingdon and New York: Routledge.

Bosworth, M. \& Guild, M. (2008). Governing through migration control: security and citizenship in Britain. British Journal of Criminology, 48(6), 703-719. https://doi.org/ 10.1093/bjc/azn059.

Bowman, D., Stokes, E., \& Rip, A. (Eds.). (2017). Embedding New Technologies Into Society: Regulatory, Ethical and Societal Perspective. Singapore: Pan Stanford Publishing.

Broeders, D. (2007). The new digital borders of Europe: EU databases and the surveillance of irregular migrants. International Sociology, 22(1), 71-92. https://doi.org/ $10.1177 / 0268580907070126$.

Chow-White, P. \& Duster, T. (2011). Do health and forensic DNA databases increase racial disparities? PLoS Medicine, 8(10), e1001100. https://doi.org/10.1371/journal. pmed.1001100.

Cole, S. \& Dioso-Villa, R. (2009). Investigating the "CSI effect" effect: media and litigation crisis in criminal law. Stanford Law Review, 61(6), 1335-1374.

Downey, J., Stephens, M., \& Flaherty, J. (2012). The 'sluice-gate' public sphere and the national DNA database in the UK. Media, Culture \& Society, 34(4), 439-456. https:// doi.org/10.1177/0163443711436357.

Duster, T. (2006). Explaining differential trust of DNA forensic technology: grounded assessment or inexplicable paranoia? Journal of Law, Medicine \& Ethics, 34(2), 293300. https://doi.org/10.1111/j.1748-720X.2006.00034.X.

Granja, R. \& Machado, H. (2020). Forensic DNA phenotyping and its politics of legitimation and contestation: views of forensic geneticists in Europe. Social Studies of Science, 1-19. https://doi.org/10.1177/0306312720945033.

Granja, R., Machado, H., \& Queirós, F. (2020). The (de)materialization of criminal bodies in forensic DNA phenotyping. Body \& Society, 1-25. https://doi.org/10.1177/ 1357034 X20919168.

Hindmarsh, R. \& Prainsack, B. (Eds.). (2010). Genetic Suspects: Global Governance of Forensic DNA Profiling and Databasing. Cambridge: Cambridge University Press.

Hopman, R. \& M'charek, A. (2020). Facing the unknown suspect: forensic DNA phenotyping and the oscillation between the individual and the collective. BioSocieties, 15, 438-462. https://doi.org/10.1057/s41292-020-00190-9.

Jasanoff, S. \& Kim, S.-H. (Eds.). (2015). Dreamscapes of Modernity: Sociotechnical Imaginaries and the Fabrication of Power. Chicago and London: University of California Press. https://doi.org/10.7208/chicago/9780226276663.001.0001. 
Jong, L. \& M'charek, A. (2017). The high-profile case as 'fire object': following the Marianne Vaatstra murder case through the media. Crime, Media, Culture: An International Journal, 14(3), 347-363. https://doi.org/10.1177/1741659017718036.

Kruse, C. (2016). The Social Life of Forensic Evidence. Chicago and London: University of California Press.

Leonelli, S. (2016). Data-Centric Biology: A Philosophical Study. Chicago: The University of Chicago Press Books.

Lynch, M., Cole, S.A., McNally, R., \& Jordan, K. (2008). Truth Machine: The Contentious History of DNA Fingerprinting. Chicago: University of Chicago Press. http s://doi.org/10.1017/CBO9781107415324.004.

M'charek, A., Schramm, K., \& Skinner, D. (2014). Topologies of race: doing territory, population and identity in Europe. Science, Technology, \& Human Values, 39(4), 468-487. https://doi.org/10.1177/0162243913509493.

M'charek, A., Toom, V., \& Jong, L. (2020). The trouble with race in forensic identification. Science, Technology, \& Human Values, 45(5), 804-828. https://doi.org/10. $1177 / 0162243919899467$.

Machado, H. \& Granja, R. (2020). DNA transnational data journeys and the constuction of categories of suspicion. Canadian Journal of Communication, 45(1), 8189. https://doi.org/10.22230/cjc.2020v45n1a3441.

Machado, H. \& Santos, F. (2009). The disappearance of Madeleine McCann: public drama and trial by media in the portuguese press. Crime, Media, Culture, 5(2), 146167. https://doi.org/10.1177/1741659009335691.

Machado, H. \& Santos, F. (2011). Popular press and forensic genetics in Portugal: expectations and disappointments regarding two cases of missing children. Public Understanding of Science, 20(3), 303-318. https://doi.org/10.1177/ 0963662509336710.

Machado, H. \& Silva, S. (2009). Informed consent in forensic DNA databases: volunteering, constructions of risk and identity categorization. BioSocieties, 4(4), 335-348. https://doi.org/10.1017/S1745855209990329.

Machado, H. \& Silva, S. (2014). "Would you accept having your DNA profile inserted in the National Forensic DNA database? Why?" Results of a questionnaire applied in Portugal. Forensic Science International: Genetics, 8(1), 132-136. https://doi.org/ 10.1016/j.fsigen.2013.08.014.

Machado, H. \& Silva, S. (2016). Voluntary participation in forensic DNA databases: altruism, resistance, and stigma. Science, Technology, \& Human Values, 41(2), 322343. https://doi.org/10.1177/0162243915604723.

Machado, H. \& Silva, S. (2019). What influences public views on forensic DNA testing in the criminal field? A scoping review of quantitative evidence. Human Genomics, 13(23), 1-13. https://doi.org/10.1186/s40246-019-0207-5.

Makhlouf, M.D. (2020). The ethics of DNA testing at the border. American Journal of Law \& Medicine, 46(2-3),253-273. https://doi.org/10.1177/0098858820933498.

Marres, N.S. (2005). No Issue, No Public: Democratic Deficits After the Displacement of Politics. Amsterdam: Ipskamp Printpartners. https://pure.uva.nl/ws/files/3890776/ 38026_thesis_nm_final.pdf.

Michael, M. (2009). Publics performing publics: of PiGs, PiPs and politics. Public Understanding of Science, 18(5), 617-631. https://doi.org/10.1177/0963662508098581.

Micheli, M., Ponti, M., Craglia, M., \& Berti Suman, A. (2020). Emerging models of data governance in the age of datafication. Big Data \& Society, 7(2), 1-15. https:// doi.org/10.1177/2053951720948087. 
Nuffield Council on Bioethics. (2007). The forensic use of bioinformation: ethical issues. London: Cambridge Publishers. http://nuffieldbioethics.org/wp-content/uploads/ The-forensic-use-of-bioinformation-ethical-issues.pdf.

Pantazis, C. \& Pemberton, S. (2009). From the "old" to the "new" suspect community: examining the impacts of recent UK counter-terrorist legislation. British Journal of Criminology, 49(5), 646-666. https://doi.org/10.1093/bjc/azp031.

Pfotenhauer, S. \& Jasanoff, S. (2017). Panacea or diagnosis? Imaginaries of innovation and the 'MIT model' in three political cultures. Social Studies of Science, 47(6), 783-810. https://doi.org/10.1177/0306312717706110.

Queirós, F. (2019). The visibilities and invisibilities of race entangled with forensic DNA phenotyping technology. Journal of Forensic and Legal Medicine, 68(101858), 1-7. https://doi.org/10.1016/j.jflm.2019.08.002.

Rip, A. (2017). Division of Moral Labour as an Element in The Governance of Emerging Technologies. In D. Bowman, E. Stokes, \& A. Rip (Eds.), Embedding New Technologies into Society: A Regulatory, Ethical and Societal Perspective (113127). Singapore: Jenny Stanford Publishing. https://doi.org/10.1201/9781315379593.

Ruppert, E., Isin, E., \& Bigo, D. (2017). Data politics. Big Data \& Society, 4(2),1-7. https://doi.org/10.1177/2053951717717749.

Samuel, G. \& Prainsack, B. (2019). Civil society stakeholder views on forensic DNA phenotyping: balancing risks and benefits. Forensic Science International: Genetics, 43(102157), 1-9. https://doi.org/10.1016/j.fsigen.2019.102157.

Skinner, D. (2012). Mobile Identities and Fixed Categories: forensic DNA and The Politics of Racialized Data. In K. Schramm, D. Skinner, \& R. Rottenburg (Eds.), Identity Politics and the New Genetics: Relcreating Categories of Difference and Belonging (53-78). New York and Oxford: Berghahn Books.

Skinner, D. (2013). "The NDNAD has no ability in itself to be discriminatory": ethnicity and the governance of the UK national DNA database. Sociology, 47(5), 976-992. https://doi.org/10.1177/0038038513493539.

Skinner, D. (2018a). Race, racism and identification in the era of technosecurity. Science as Culture, 29(1), 77-99. https://doi.org/10.1080/09505431.2018.1523887.

Skinner, D. (2018b). Forensic genetics and the prediction of race: what is the problem? BioSocieties, 15, 329-349. https://doi.org/10.1057/s41292-018-0141-0.

Skinner, D. \& Wienroth, M. (2019). Was this an ending? The destruction of samples and deletion of records from the UK police national DNA database. BJHS Themes, 4, 99-121. https://doi.org/10.1017/bjt.2019.7.

Tutton, R., Hauskeller, C., \& Sturdy, S. (2014). Suspect technologies: forensic testing of asylum seekers at the UK border. Ethnic and Racial Studies, 37(5), 738-752. http s://doi.org/10.1080/01419870.2013.870667.

Wallace, H., Jackson, A., Gruber, J., \& Thibedeau, A. (2014). Forensic DNA databases: ethical and legal standards - a global review. Egyptian Journal of Forensic Sciences, 4(3), 57-63. https://doi.org/10.1016/j.ejfs.2014.04.002.

Wienroth, M. (2018). Governing anticipatory technology practices. Forensic DNA phenotyping and the forensic genetics community in Europe. New Genetics and Society, 37(2), 137-152. https://doi.org/10.1080/14636778.2018.1469975.

Wienroth, M., Morling, N., \& Williams, R. (2014). Technological innovations in forensic genetics: social, legal and ethical aspects. Recent Advances in DNA and Gene Sequences, 8(2), 98-103.

Williams, R. \& Johnson, P. (2004). Circuits of surveillance. Surveillance \& Society, 2 (1), 1-14. https://doi.org/10.1901/jaba.2004.2-1. 
Williams, R. \& Johnson, P. (2008). Genetic Policing: The Use of DNA in Criminal Investigations. Cullompton: Willan Publishing.

Williams, R. \& Wienroth, M. (2014). Ethical, social and policy aspects of forensic genetics: A systematic review, 1-81. EUROFORGEN-NoE. http://nrl.northumbria. ac.uk/id/eprint/16313/1/Forensic_Genetics_ELSA_Review_Williams_Wienroth.pdf.

Williams, R. \& Wienroth, M. (2017). Social and ethical aspects of forensic genetics: a critical review. Forensic Science Review, 29(2), 145-169.

Wilson-Kovacs, D., Wyatt, D., \& Hauskeller, C. (2012). “A Faustian bargain?” Public voices on forensic DNA technologies and the national DNA database. New Genetics and Society, 31(3), 285-298. http://www.tandfonline.com/doi/abs/10.1080/14636778. 2012.687085 . 


\section{Conclusion}

\section{Introduction}

The expanding uses of genetic surveillance in crime governance pose important challenges to democratic societies in the 21 st century. This book has aimed to provide empirically sustained information upon which to develop a critical reflection on these pressing issues, namely: the many problems raised by the emergence, consolidation and spreading of genetic surveillance for the governance of crime in Europe; the transnational exchange of DNA data among laboratories and police agencies in the European Union (EU); the risks of racism, discrimination and stigmatization of groups, families, and individuals resulting from poorly regulated forensic technologies; the growing use of genome-wide technologies and the consequent blurring of boundaries between the criminal and medical fields; and the prevalence of deficient civic engagement, coupled with gaps in transparency and accountability of state surveillance activities involving genetic technologies and criminal DNA databases.

By addressing such topics, this book portrayed the ambiguous and convoluted social, cultural, political and historical processes involved in the expansion of centralized and decentralized modes of genetic surveillance for the governance of crime. By centralized modes $^{1}$ of genetic surveillance, we mean the genetic data stored in large, computerized databases, run by public authorities within the criminal justice system. In this respect, we are referring to state criminal DNA databases that operate under the legal regulation and data sovereignty principles of national jurisdictions (Hindmarsh \& Prainsack, 2010). Decentralized modes of genetic surveillance imply the activity of entities other than national DNA databases and their use of data, especially of genetic nature, to prevent, solve and punish crimes. For example, in local laboratories and commercial companies (Granja, 2020; Samuel \& Kennett, 2020), and in networks such as the Prüm system - a decentralized database system designed to facilitate the mandatory exchange of forensic DNA data among EU Member States to control criminality and terrorism (Machado \& Granja, 2018; Machado, Granja, \& Amelung, 2020; McCartney, Wilson \&

DOI: $10.4324 / 9780429261435-8$ 
Williams, 2011; Prainsack \& Toom, 2010, 2013) - a case study that actually provided our empirical starting point for this work.

But although Prüm provided a starting point, our data and the scope of our reflections greatly exceed this particular case. In this book, we explored power relations, subjectivities and social identities constructed and performed by geneticists and other stakeholders in the specific field of forensic genetics, as a response to demands of the criminal justice in its endeavors to advance criminal identification. Our reflections allowed us to explore the implications of being a scientist, a member of transnational police agencies, or an activist in the area of human rights dealing with genetics and crime governance in the course of the first two decades of the 21 st century. This is a particularly crucial period in forensic genetics since, despite the already consolidated role achieved by DNA technologies in providing evidence for criminal justice (Lynch et al., 2008), the recent ongoing development of new forensic DNA technologies - such as familial searches, forensic DNA phenotyping, and next generation sequencing (NGS) - represent a historical turning point in terms of the presence of forensic genetic technologies in the criminal justice system. First, because it implies a shift in the focus of forensic science from the construction of evidence to the generation of intelligence (Wienroth, 2018); and second, because these emergent DNA technologies move the locus of surveillance from individualization to collectivization (M'charek \& Wade, 2020). Thus, our enquiry into genetic surveillance for the governance of crime was guided by the following research questions: to what extent and in what way do shifts in power and in assumptions about knowledge, affect scientific, policing, or activism practices? Who are the people behind the technologies, and how do they address the difficult ethical challenges and professional issues that arise in a period when the uses of genetic technologies in the forensic field are undergoing dramatic changes?

Since our primary interlocutors were forensic geneticists, this book provides the social sciences with a relevant contribution to understand scientists' constant endeavor to interpret the present through their projections of an imagined emerging future riddled with volatility, caution and uncertainty (Marcus, 1995). Our work also contributes to the science and technology studies (STS) scholarship on science representation and knowledge construction, as well as to the relationships between science and politics. In line with the influential work by Bruno Latour (1987), our work demonstrates the extraordinary mobility of scientific representations of DNA data, showing how scientific protocols and processes of harmonization and standardization tend to move from particularity to universality. In the wake of our own past work, (Amelung, Granja, \& Machado, 2020a; Granja \& Machado, 2020; Machado \& Granja, 2018, 2019) we have also explored how scientists' expectations engage with distributed responsibilities among the scientific community and the criminal justice system, legitimating and protecting the autonomy of science in a messy, complex and sometimes ambiguous way (Lawless, 2012). 
Although our book provides a contribution to the knowledge on "technoscientific imaginaries," in the sense conveyed by other scholars in STS - as the reflective and visionary thought of scientists in their ambiguous positionings, practices, and locations - we have sought to go beyond the realm of the imagination. Specifically, we outline how aims and achievements are tied to forms of scientific production (Jasanoff, 2015), questioning how the mobility of scientific representations contribute to reinforce distinctions between centers and peripheries (Latour, 1987) in the EU. Our ambition in this book has also exceeded the context of science production: our work aimed to investigate how the imaginings constructed by varied social actors influence the way science and technology in the domain of forensic genetics become enmeshed in performing and producing diverse visions of governance of crime, at a variety of scales and affecting diverse publics.

\section{The continuum of utopian and dystopian imaginings of genetic surveillance}

The findings presented in this book might be framed as elements deriving from the power of imagining produced within genetic surveillance in the governance of crime. The term "imaginings" is used here in the sense intended by a number of social theorists and philosophers, as the shared conceptions which enable common practices and a widely accepted sense of legitimacy. In fact, our work has been deeply inspired by the term "sociotechnical imaginaries" - a concept coined by Sheila Jasanoff and developed in close collaboration with Sang-Hyun Kim (Jasanoff \& Kim, 2009, 2015) to describe how visions of scientific and technological progress carry implicit ideas about public purposes, collective futures, and the common good. The "sociotechnical imaginaries" we have explored in this book refer, for instance, to the continuum of utopian and dystopian imaginings of genetic surveillance in the governance of crime, described by Robin Williams and Mathias Wienroth as follows:

The promissory narratives of some - policy and commercial - advocates of the expanding uses of forensic genetics have often been contested by social actors outside the scientific, policy and commercial networks that are directly involved in promoting relevant innovations. While utopian narratives might have dominated some accounts of this history, civil society and academic groups have often offered dystopian counter narratives in which the uses of forensic genetics and their consequences are imagined quite differently.

(Williams \& Wienroth, 2014, p. 15)

Over the past decades, different fields within the social sciences, and most preeminently STS, have shown the distribution of visions and expectations in relation to the contrasting positioning of different actors (scientists, regulators, 
publics, etc.) in the technological innovation cycles and in the processes of establishing technical infrastructures and stabilized scientific protocols (Lynch et al., 2008; Lynch, 2016). In addition, STS studies have also underlined the decisive role of the heterogeneous and hybrid socio-technical character of technology and knowledge production, and how views referring to technology and its uses are able to draw together highly heterogeneous actors (Berger \& Luckmann, 1996; Hacking, 2000; Sismondo, 2003). In this book we developed an in-depth understanding of the values, judgements, power relations, and agendas incorporated in the hopes and promises, as well as in the fears and anxieties regarding genetic surveillance in the governance of crime. This volume has thus provided a mapping and interpretation of visions and expectations, understanding the extent to which "utopian" and "dystopian" visions of forensic genetic technologies are shared among different stakeholders and practitioners, or conversely might be specific to certain stakeholders only.

Besides the pivotal role played by the concept of "sociotechnical imaginaries," the work of authors such as Benedict Anderson (1983), Arjun Appadurai (1990), and Charles Taylor (2004) also became important tools for deepening our understanding of genetic technologies in the governance of crime, connecting it to broader questions of social and political theory. Anderson's work (1983) and his idea of an imagined community led us to explore the subjective dimension of inclusion and exclusion of a group, be it a professional community, a nation state or the very idea of the EU, as it is shared or resisted by different individuals, groups and communities (Amelung, Granja \& Machado, 2020b). On this point, it is important to clarify the diversity of communities whose points of view were addressed in this book. Our use of qualitative methods from the social sciences, gave us an insight into how "imagined communities" are formed. We were able to understand that individuals working in forensic genetics or in EU police cooperation tend to imagine themselves as communities in the terms proposed by Benedict Anderson (1983): a socially constructed community, imagined by the people who perceive themselves as members of that group. Although Anderson's work originally focuses on the analysis of nationalism, his conceptualization of imagination as a means to grasp subjective and "imagined" dimension of a community, proved highly useful for our own understanding of the complex and sometimes contradictory nature of the narratives constructed by the participants in our work. For instance, participants might sometimes refer to their "European" or "international" community, in the sense of a group made up of members scattered across different countries but working together toward common goals, while at the same time occasionally describing themselves as included in logics of social exclusion and discrimination of particular nation-states towards specific groups (non-nationals) (for further readings, see Machado \& Granja, 2019, 2020; Machado, Granja, \& Amelung, 2020).

Arjun Appadurai's work (1990) has also decisively marked our analysis by providing a framework within which to interpret genetic surveillance in the governance of crime as a global phenomenon, albeit constantly transfigured 
by what the author calls "imagined words" - that is, the multiple worlds constituted by the historically shaped imaginations of groups and people spread around the globe (see also Appadurai, 2010). The emphasis of Appadurai's work on the role of the imagination in legitimizing what he calls the "disjuncture and difference in global cultural economy" (Appadurai, 1990), allows us to understand the fluidity, complexity and hybridity of the expectations created by a myriad of social actors differently positioned in relation to genetic technologies. The results obtained in our investigation lead us to agree with Appadurai when he affirms the complex, overlapping, and disjunctive character of the new global cultural economy. In the light of this, appreciating how genetic surveillance in the governance of crime is "imagined," becomes a central point to explain two key aspects: on the one hand, the fluid and volatile nature of center and periphery relations within the EU concerning the diffusion of technology and science, the dissemination of technological innovation in the area of forensic genetics and the expansion of genetic databases. On the other hand, we realize that genetic technologies now move within what Appadurai calls a "technoscape," as one of the dimensions of the global cultural flow and its inherent bridging of previously impenetrable boundaries (Appadurai, 1990, p. 297).

As previously stated, the empirical study that formed the basis of this book was developed in the arena of EU politics on police and judicial cooperation in the fight against crime and terrorism, more specifically taking the Prüm system as its starting point. Although our approach lead us well beyond this particular phenomenon, the Prüm system maintained its centrality throughout, giving us access to interviews or conversations with diverse social actors interested in elaborating on their views about genetic surveillance in the governance of crime. In this regard, Charles Taylor's work (2004) was particularly useful and inspiring, namely his analysis of the role played by elites in shaping the imaginary on which a given social reality is construed, while other social actors actively resist, reinforce or transform this moral order imposed from above. Based on this analysis, we are led to interpret the institutional framing of the Prüm system as a conceptual construction upheld by EU political elites connected to social structures of western modernity - the economy, the public sphere, the nation-state, and transnational borders - while also incorporating the practices and ideas produced in much broader forms of imagination circulating among other groups. In the case of our work these other groups include forensic geneticists, laboratory practitioners, members of police organizations, and activists. In sum, following the investigative paths trailed by Taylor (2004), we have addressed genetic surveillance in the governance of crime as embedded in social imaginaries that form a common understanding, which simultaneously reinstates the common sense, mobilizes a variety of knowledge and enables the practices that constitute social life.

\section{Biosociality in forensic genetics}

If we had to choose a single word to describe the main contribution of our work to the scholarship of the social studies in the specific field of forensic 
genetics, it would possibly be summarized best by the notion of "biosociality" - a term coined by the anthropologist Paul Rabinow following developments occurred in the field of genetics in the late 1990s linked to research on the human genome (Rabinow, 1996). We believe this work to be, above all, an innovative contribution to deepening and broadening the scientific and academic debate on how the bio, social and cultural elements mutually interact, interplay, and reinforce each other. As a heuristic category, biosociality was primarily conceived to highlight the new hybrid relationships between biology and culture made possible by research and intervention in the human genome. Thus, it might be considered as an experimental tool for examining the interface between recent developments in the life sciences, social practices, and individual and collective subjectivities.

Our findings and analysis presented in this book contribute to broadening the understanding of forms of biosociality in the particular context of forensic genetics: addressing genetic surveillance for crime governance reveals the dynamics of complex and ever-changing processes and practices that draw the bio and the social together so as to reconstruct, reshape, and diffuse their effects upon the field of criminal identification and their multiple and hybrid intertwining with forms of coordination between knowledge, truth, and action.

During the last two decades, social sciences work has illuminated the variable and diverse manifestations of biosocialities, with a particular focus on developments in the field of biomedicine (Gibbon \& Novas, 2008; Raman \& Tutton, 2009; Valle \& Gibbon, 2015). Other works have sought to extend the boundaries of biosociality defined by Paul Rabinow to the field of forensic genetics (Lynch \& McNally, 2009; Tutton \& Levitt, 2010). Michael Lynch and Ruth McNally, in their work about forensic DNA databases and novel configurations of suspect bodies, proposed the term "biolegality" to define a symbiotic relationship between law and biotechnology (2009, p. 284). In their words:

Biolegality is a type of biosociality that involves different identity categories than those associated with the biomedical sociality (...) instead of producing "at risk" medical identities, biolegality produces "risky" suspects, "pre-suspects," and "statistical suspects" (...) although "selves" are deeply implicated, suspect identity is primarily an object and product of policing and forensic expertise, rather than a technically defined basis for the formation of the individual and group identity. One of the features of the biolegal marking of the bodies is its potential to expand, driven by diverse logics, potentially encompassing entire populations.

(Lynch \& McNally, 2009, p. 284)

In our perspective, this book has gone beyond manifestations of what Lynch and McNally called "biolegality" as a form of biosociality in forensic genetics, by exploring manifestations of "biological citizenship." One important 
work for inspiring our reflection was the text by Richard Tutton and Mairi Levitt (2010) which proposed to explore the convergences and divergences evinced in the development of forensic and biomedicine databases, aiming to provide innovative and productive insights into the forensic arena. The authors used the discussions of biological citizenship (Petryna, 2002; Rose \& Novas, 2005) - a new type of citizenship that has been taking shape in the age of biomedicine, biotechnology and genomics - to explore the forms of biological citizenship in the context of forensic genetic databases (Tutton \& Levitt, 2010). In the medical domain, the "biological citizen" might seek to relate to others in biological terms by seeking alliances and forming communities with those who might share a genetic trait or disease. Biological citizenship in the medical domain is therefore oriented by social values such as choice, autonomy, and self-responsibility (Rose \& Novas, 2005; Tutton \& Levitt, 2010, pp. 95-100).

In the field of forensic genetics, biological citizenship has to be approached in a quite different manner. There are, indeed, a few instances where selforganizing citizens made to provide a biological sample for a criminal genetic database, formed support and advocacy organizations (Amelung \& Machado, 2019). The range of action of non-governmental organization in denouncing the potential abuses of genetic surveillance is also preeminent in the public space, particularly in countries like the UK (see Chapter 7). However, rather than the autonomous and individual self-governance described by Nikolas Rose and Carlos Novas (2005), in the field of forensic genetics, biological citizens have to conform to a category imposed by the state (Machado \& Prainsack, 2012), socially sorted into suspect and non-suspect police categories. In the words of Richard Tutton and Mairi Levitt:

From the perspective of biological citizenship, we might read inclusion in the police database as the removal of choice and self-responsibility, as reducing individuals to the 'bare life' of being a data subject on a police database.

(Tutton \& Levitt, 2010, p. 99)

This book demonstrated the limitations of centering the discussion of biological citizenship and its inherent social sorting on the activities of social control and surveillance enacted by the state. The discourses of forensic geneticists, members of police agencies and social actors involved in the arena of human rights protection, play an increasingly relevant role in the social and political construction of "biological citizens" - whether "DNA donor," "arrestee," "suspect," "criminal," "volunteer," "victim," "common citizen," or "affected public." This book paid particular attention to a specific group of stakeholders: the forensic geneticists who work in forensic laboratories and/or university forensic science departments in different European countries. This focus is justified by the central role played by forensic geneticists as social actors in constructing and defining forms of citizenship that exceed the strict 
set of rights and obligations applied of individuals who provide biological samples to satisfy security and legal purposes. Therefore, one relevant contribution of our book has been to further the exploration of social, cultural, and political constructions of biological citizenship through the views, practices, and expectations formulated and performed by forensic geneticists.

This book expands also the theme of biosociality in forensic genetics by addressing underexplored topics that emerge from the connection between various practices, actors, social forms and subjectivities with genetic surveillance applied to the governance of crime. An important aspect of our work was to show that the socio-cultural dynamics produced by genetic surveillance for criminal identification are bound up with novel practices of knowing and manipulating the biological body, mobilizing scientific knowledge of the human genome, and reifying certain visions, promises, and expectations about the future. In sum, this volume has sought to promote a critical reflection on the social and political transformations that result from genomic knowledge and technology - biosocialities - in the forensic genetics field.

As we claimed elsewhere (Granja \& Machado, 2020; Granja, Machado, \& Queirós, 2020), the networks of professionals with expertise and competence in the specific domain of genetics applied to criminal identification, possess an authoritative status that might deeply impact both policy-oriented strategies, as the negotiation of future developments in genetic surveillance for the governance of crime. Besides considering the role of forensic geneticists, we also explored the implications of other stakeholders' actions, such as non-governmental organizations - concerned with the protection of human rights and the threats posed by genetics and biometric technologies - as well as the views and actions of professionals dedicated to international police cooperation in DNA data exchange used to fight cross-border crime and terrorism. From those perspectives, we concluded that the modes of genetic surveillance for the governance of crime are co-produced and informed by political, ethical and historical contexts, while at the same time highlighting preexisting social vulnerabilities and inequalities that instigate transformations in citizenship and subjectivities. Combined, these social, cultural, and political constellations form a common matrix within which to address genetic surveillance for the governance of crime through the lens of biosociality.

\section{Paths for future research}

This book reflects upon how the forensic technologies established as the "gold standard" of identification (Lynch, 2003) have been subjected to continuous expansion and investment with the aim of further increasing its capabilities, either through the complex architectures of EU transnational police and judicial collaboration and/or through increasingly sophisticated methods of analysis able to expand genetic informativity. This implies that while forensic geneticists, laboratory practitioners, members of police organizations, and activists continue to be faced with a set of issues that have been identified as 
ethically and pragmatically challenging, other increasingly complex questions continue to emerge. Among those that remain as long-standing unsolved controversies in forensic genetics, we could list the following: the communication of forensic genetics across different domains of practice and diverse epistemic cultures (Amelung, Granja, \& Machado, 2020a; Amorim, 2012; Kruse, 2013; Machado \& Granja, 2019); the discriminatory potential of genetic technologies and databases (M'charek, Toom, \& Jong, 2020; Skinner, 2013); the disparate models for regulation, legislation and organization of increasingly connected databasing systems (Santos, Machado, \& Silva, 2013), and the insufficient civic involvement and gaps in transparency and accountability in the establishment and expansion of genetic databases (Amelung \& Machado, 2019; Toom, Granja, \& Ludwig, 2019). As new issues continue to arise, the different actors are faced with additional challenges: the expansion of transnational systems without a corresponding efficacy assessment (Toom et al., 2019); the obsolescence of certain legal and regulatory frameworks in the light of forensic genetics' permanent transformations (Samuel \& Prainsack, 2018); the increasing intersection between systems conceived for criminal investigation and civil identification (Smith, 2017); the increasing relevance of private providers specialized in complex analysis (Wienroth, 2020), whose promises are considered scientifically unsound by some forensic geneticists (Granja \& Machado, 2020); and the blurring of boundaries between previously distinct kinds of genetic collection and genetic practice. On this last topic, we emphasize both the increasing connections between the medical and forensic fields, made possible by the development and investment in NGS, and the use of recreational DNA databases for criminal investigation purposes (Granja, 2020; Samuel \& Kennett, 2020). These ongoing debates reveal the coexistence of old and new controversies within forensic genetics, demonstrating the need to continue investing in research that can point the critical lens of the social sciences on this highly specialized and technological field of knowledge. While the aim of this book was to explore some these themes within the context of the EU, the interrogations and conclusions it presents can be projected to other political, socio-economic and cultural spaces. More particularly, we believe it might be useful to address other contexts that are highly invested in establishing and expanding forensic technologies but which remain largely underexplored. Moreover, such an exercise serves to resist the temptation of treating the social, ethical, and political challenges of genetic surveillance for the governance of crime a "universal" phenomenon, promoting analyses grounded on a situatedness that anchors them in broader historical, social, and political issues. We believe that such an in-depth analysis provides a vital instrument for scientists, as well as for the commissioners and users of research, to develop an understanding of the various social and ethical promises and problems posed by emerging technologies, thus helping to better negotiate between the rationales behind new ethical and human rights challenges, and new deficits of transparency, accountability, and public trust. 
Finally, we hope that the findings presented in this book might be used as a source in the design of pragmatic recommendations to support the ethically responsible implementation and use of forensic technologies. Although this book avoids evaluating or assessing the phenomenon of genetic surveillance for the governance of crime in any normative way, we cannot ignore the potentially significant impact of our reflections in addressing two main societal challenges at a national, European, and global levels (UN Agenda 2030) fostering just and inclusive societies and envisaging a world of respect for human rights and dignity, justice, equality and non-discrimination.

\section{Note}

1 Centralized database systems might have other meanings. An important body of scholarship has dedicated attention to the political and technical integration of biometric data at the EU level (Amelung, Granja, \& Machado, 2020b; Misa \& Schot, 2005; Rommetveit, 2016). The Visa Information System (VIS), Schengen Information System II (SIS II), and EURODAC are examples of the largest and most important centralized database systems operating in the EU.

\section{References}

Amelung, N., Granja, R., \& Machado, H. (2020a). Communicating Forensic Genetics: "Enthusiastic" Publics and the Management of Expectations'. In S. Davies \& U. Felt (Eds), Exploring Science Communication (209-226). London: SAGE Publications.

Amelung, N., Granja, R., \& Machado, H. (2020b). Modes of Bio-bordering: The Hidden (Dis) integration of Europe (1st ed.). London: Palgrave Macmillan. https:// doi.org/10.1007/978-981-15-8183-0.

Amelung, N. \& Machado, H. (2019). Affected for good or for evil: the formation of issue-publics that relate to the UK national DNA database. Public Understanding of Science, 28(5), 590-605. https://doi.org/10.1177\%2F0963662519836346.

Amorim, A. (2012). Opening the DNA black box: demythologizing forensic genetics. New Genetics and Society, 31(3), 259-270. https://doi.org/10.1080/14636778.2012. 687083.

Anderson, B. (1983). Imagined Communities: Reflections on the Origin and Spread of Nationalism. London and New York: Verso.

Appadurai, A. (1990). Disjuncture and difference in the global cultural economy. Theory, Culture \& Society, 7(2-3),295-310. https://doi.org/10.1177/026327690007002017.

Appadurai, A. (2010). How histories make geographies. The Journal of Transcultural Studies, 1(1), 4-13. https://doi.org/10.11588/ts.2010.1.6129.

Berger, P.L. \& Luckmann, T. (1996). The Social Construction of Reality: A Treatise in the Sociology of Knowledge. New York: Doubleday.

Gibbon, S. \& Novas, C. (2008). Biosocialities, Genetics and the Social Sciences: Making Biologies and Identities. London: Routledge.

Granja, R. (2020). Long-range familial searches in recreational DNA databases: expansion of affected populations, the participatory turn, and the co-production of biovalue. New Genetics and Society, 1-22. https://doi.org/10.1080/14636778.2020. 1853515. 
Granja, R. \& Machado, H. (2020). Forensic DNA phenotyping and its politics of legitimation and contestation: views of forensic geneticists in Europe. Social Studies of Science, 1-19. https://doi.org/10.1177/0306312720945033.

Granja, R., Machado, H., \& Queirós, F. (2020). The (de)materialization of criminal bodies in forensic DNA phenotyping. Body \& Society, 1-25. https://doi.org/10.1177/ 1357034 X20919168.

Hacking, I. (2000). The Social Construction of What?Cambridge: Harvard University Press.

Hindmarsh, R. \& Prainsack, B. (Eds). (2010). Genetic Suspects: Global Governance of Forensic DNA Pprofiling and Databasing. Cambridge: Cambridge University Press.

Jasanoff, S. (2015). Future Imperfect. In S. Jasanoff \& S.-H. Kim, Dreamscapes of Modernity: Sociotechnical Imaginaries and the Fabrication of Power (1-33). Chicago and London: University of Chicago Press. https://doi.org/10.7208/chicago/ 9780226276663.003.0001.

Jasanoff, S. \& Kim, S.-H. (2015). Dreamscapes of Modernity: Sociotechnical Imaginaries and the Fabrication of Power. Chicago and London: University of California Press. http://www.press.uchicago.edu/ucp/books/book/chicago/D/bo20836025.html.

Jasanoff, S. \& Kim, S.-H. (2009). Containing the atom: Sociotechnical imaginaries and nuclear power in the United States and South Korea. Minerva, 47(2), 119-146. http s://doi.org/10.1007/s11024-009-9124-4.

Kruse, C. (2013). The bayesian approach to forensic evidence - evaluating, communicating, and distributing responsibility. Social Studies of Science, 43(5), 657-680. https://doi.org/10.1177/0306312712472572.

Latour, B. (1987). Science in Action. How to Follow Scientists and Engineers Through Society. Cambridge: Harvard University Press.

Lawless, C. (2012). The low template DNA profiling controversy: biolegality and boundary work among forensic scientists. Social Studies of Science, 43(2), 191-214. https://doi.org/10.1177/0306312712465665.

Lynch, M. (2003). God's signature: DNA profiling, the new gold standard in forensic science. Endeavour, 27(2), 93-97. https://doi.org/10.1016/S0160-9327(03)68-61.

Lynch, M., Cole, S.A., McNallly, R., \& Jordan, K. (2008). Truth Machine: The Contentious History of DNA Fingerprinting. Chicago: University of Chicago Press. http s://doi.org/10.1017/CBO9781107415324.004.

Lynch, M. (2016). Social constructivism in science and technology studies. Human Studies, 39(1), 101-112. https://doi.org/10.1007/s10746-016-9385-5.

Lynch, M. \& McNally, R. (2009). Forensic DNA Databases: The Co-production of Law and Surveillance Technology. In P. Atkinson, P. Glasner, \& M. Lock (Eds), Handbook of Genetics and Society: Mapping the New Genomics Era (283-301). London: Routledge.

M'charek, A., Toom, V., \& Jong, L. (2020). The trouble with race in forensic identification. Science, Technology, \& Human Values, 45(5), 804-828. https://doi.org/10. $1177 / 0162243919899467$.

M'charek, A. \& Wade, P. (2020). Doing the individual and the collective in forensic genetics: governance, race and restitution. BioSocieties, 15(3), 317-328. https://doi. org/10.1057/s41292-020-00193-6.

Machado, H. \& Granja, R. (2018). Ethics in transnational forensic DNA data exchange in the EU: constructing boundaries and managing controversies. Science as Culture, 27(2), 242-264. https://doi.org/10.1080/09505431.2018.1425385. 
Machado, H. \& Granja, R. (2019). Police epistemic culture and boundary work with judicial authorities and forensic scientists: The case of transnational DNA data exchange in the EU. New Genetics and Society, 38(3), 289-307. https://doi.org/10. 1080/14636778.2019.1609350.

Machado, H. \& Granja, R. (2020). DNA transnational data journeys and the construction of categories of suspicion. Canadian Journal of Communication, 45(1), 8189. https://doi.org/10.22230/cjc.2020v45n1a3441.

Machado, H., Granja, R., \& Amelung, N. (2020). Constructing suspicion through forensic DNA databases in the EU. The views of the Prüm professionals. The British Journal of Criminology, 60(1), 141-159. https://doi.org/10.1093/bjc/azz057.

Machado, H. \& Prainsack, B. (2012). Tracing Technologies: Prisoners' Views in the Era of CSI. Farnham: Ashgate.

Marcus, G.E. (1995). Ethnography in/of the worlds system: the emergence of multisited ethnography. Annual Review of Anthropology, 24(1), 95-117. https://doi.org/10. 1146/annurev.an.24.100195.000523.

McCartney, C., Wilson, T., \& Williams, R. (2011). Transnational exchange of forensic DNA: viability, legitimacy, and acceptability. European Journal on Criminal Policy and Research, 17(4), 305-322. https://doi.org/10.1007/s10610-011-9154-y.

Misa, T.J. \& Schot, J. (2005). Inventing europe: technology and the hidden integration of Europe. History and Technology, 21(1), 1-19. https://doi.org/10.1080/ 07341510500037487.

Petryna, A. (2002) Life Exposed: Biological Citizens after Chernobyl. Princeton, NJ: Princeton University Press.

Prainsack, B. \& Toom, V. (2010). The Prüm regime. Situated dis/empowerment in transnational DNA profile exchange. British Journal of Criminology, 50(6), 11171135. https://doi.org/10.1093/bjc/azq055.

Prainsack, B. \& Toom, V. (2013). Performing the union: the Prüm decision and the european dream. Studies in History and Philosophy of Biological and Biomedical Sciences, 44(1), 71-79. https://doi.org/10.1016/j.shpsc.2012.09.009.

Rabinow, P. (1996). Essays on the Anthropology of Reason. Princeton: Princeton University Press. https://doi.org/10.2307/1576556.

Raman, S. \& Tutton, R. (2009). Life, science, and biopower. Science, Technology \& Human Values, 35(5), 711-734. https://doi.org/10.1177\%2F0162243909345838.

Rommetveit, K. (2016). Introducing Biometrics in the European Union: Practice and Imagination. In A. Delgado (Ed.), Technoscience and Citizenship: Ethics and Governance in the Digital Society (113-126). New York: Springer International Publishing. https://doi.org/10.1007/978-3-319-32414-2_8.

Rose, N. \& Novas, C. (2005). Biological Citizenship. In S.J. Collier \& A. Ong (Eds), Global Assemblages: Technology, Politics, and Ethics as Anthropological Problems (439-463). Malden, MA: Blackwell Publishers.

Samuel, G. \& Kennett, D. (2020). The impact of investigative genetic genealogy: perceptions of UK professional and public stakeholders. Forensic Science International: Genetics, 48, 1-9. https://doi.org/10.1016/j.fsigen.2020.102366.

Samuel, G. \& Prainsack, B. (2018). The regulatory landscape of forensic DNA phenotyping in Europe. VISAGE, 1-119. www.visage-h2020.eu/Report_regulatory_la ndscape_FDP_in_Europe2.pdf.

Santos, F., Machado, H., \& Silva, S. (2013). Forensic DNA databases in european countries: is size linked to performance? Life Sciences, Society and Policy, 9(12), 113. https://doi.org/10.1186/2195-7819-9-12. 
Sismondo, S. (2003). The Social Construction of Scientific and Technical Realities. In S. Sismondo (Ed.), An Introduction to Science and Technology (1st ed.), (51-64). Hoboken: Blackwell Publishers. www.f.waseda.jp/sidoli/Sismondo_Introduction_ STS_6.pdf.

Skinner, D. (2013). "The NDNAD has no ability in itself to be discriminatory": ethnicity and the governance of the UK national DNA database. Sociology, 47(5), 976-992. https://doi.org/10.1177/0038038513493539.

Smith, L.A. (2017). The missing, the martyred and the disappeared: global networks, technical intensification and the end of human rights genetics. Social Studies of Science, 47(3), 398-416. https://doi.org/10.1177/0306312716678489.

Taylor, C. (2004). Modern Social Imaginaries. Durham: Duke University Press.

Toom, V., Granja, R., \& Ludwig, A. (2019). The Prüm decisions as an aspirational regime: reviewing a decade of cross-border exchange and comparison of forensic DNA data. Forensic Science International: Genetics, 41, 50-57. https://doi.org/10. 1016/j.fsigen.2019.03.023.

Tutton, R. \& Levitt, M. (2010). Health and Wealth, Law and Order: Banking DNA Against Disease and Crime. In R. Hindmarsh \& B. Prainsack (Eds), Genetic Suspects: Global Governance of DNA Profiling and Databasing (85-104). Cambridge: Cambridge University Press.

Valle, C.G.D. \& Gibbon, S. (2015). Introduction-health/illness, biosocialities and culture. Vibrant: Virtual Brazilian Anthropology, 12(1), 67-74.

Wienroth, M. (2018). Governing anticipatory technology practices. Forensic DNA phenotyping and the forensic genetics community in Europe. New Genetics and Society, 37(2), 137-152. https://doi.org/10.1080/14636778.2018.1469975.

Wienroth, M. (2020). Socio-technical disagreements as ethical fora: Parabon NanoLab's forensic DNA Snapshot ${ }^{\mathrm{TM}}$ service at the intersection of discourses around robust science, technology validation, and commerce. BioSocieties, 15(1), 28-45. https://doi.org/10.1057/s41292-018-0138-8.

Williams, R. \& Wienroth, M. (2014). Public perspectives on established and emerging forensic genetics technologies in Europe: a preliminary report, 1-46. EUROFORGEN-NoE. 


\section{Index}

Page numbers in bold refer to tables. Page numbers followed by " $n$ " refer to notes.

abandoned DNA $146 n 3$

affected populations, in familial searches 143

Amelung, Nina 16n3, 23, 67, 113, 166

Anderson, Benedict 181

anticipatory governance 15, 145, 169

Appadurai, Arjun 181-182

Austria 16n2, 31, 51, 58, 97, 113

Balkans 76

Belgium 16n2, 31, 50, 61, 78, 113

Beraldo, Davide 154

Bigo, Didier 52, 58, 60, 172

biolegality 3, 183

biological citizenship 15, 155, 157, 172, 183-184

biosociality $182-185$

Björklund, Fredrika 75

Borup, Mads 66

Brown, Nik 135, 138

Bulgaria 59, 71-72, 78-79, 84

Burck, Charlotte 8

Campaign against DNA collection frenzy $173 n 1$

Canada 143

Caparini, Marina 75

CEE countries see Central and Eastern Europe (CEE) countries

Central and Eastern Europe (CEE) countries 13, 71; forensic DNA databases in 77-78, 77; genetic surveillance expansion 77-80; historical legacy and criminality 74-77; police forces and legacy influence 80-83; Prüm system and criminalization of 83-87; surveillance vulnerability in 73; see also European Union (EU)

China: DNA databases 23-24; Uyghurs ethnocide in 22

citizens distrust, in police forces $81-82$ civic education 155-156

civil identification, familial searching in 14, 95-96, 95; between control and care 112-116; providing historical reparation $110-116$

co-construction, of suspicion $85-86$

CODIS database 24, 98

Cole, Simon 140

collective expectations $13,54,57,60,64$ collective memories $74,87-88$

"contentious politics of data" 154 , 160,163

co-production of biovalue, in familial searches 143-144

crime governance, $6,25,177,179,183$; see also genetic surveillance

criminal investigation, familial searching in $14,95,95,106,116$; ethical issues and logistical challenges 99-103; expanding suspicion in 99-110; politics of legitimation 107-110, 117; regulation/regulatory lag 103-107

Croatia 113

cross-border crimes 83,185

CSI effect 4, 28, 36

Czechoslovakia 72

Czech Republic 71, 72, 77, 79, 113

DAPIX see Data Protection and Information Exchange (DAPIX) 


\section{Index}

data politics 154, 158, 166, 171, 172

Data Protection and Information Exchange (DAPIX) 55

DeAngelo, Joseph James 143, 146n1

Debys-Sherril, Sara 96

degraded DNA samples 137

democratic engagement 16,156

Denmark 31, 113

DNA databases 27, 125, 139; in China 23-24; CODIS 24; in Europe 32, 32; expansionist legislation 31,78 ;

GEDmatch 143, 146n2; interoperability of 3; National DNA Database

(NDNAD) 24, 94, 108, 159; public surveys and opinion polls 164; restrictive legislation $31-32,78$; in USA 24

DNA fingerprints 27,28

DNA hits, within Prüm system 63

DNA-identification 14, 112-113, 116

DNA profiling 2, 26; developments in 11, 125; ethico-political domain 4, 4; juridical-scientific domain 3, 4; operational domain 3-4, 4; regulation in criminal trials 27; short-term random based xiii; visions on 35-36, 36

DNA samples 21, 32, 78-79, 94, 137

DNA Wars 28

ECHR see European Court of Human Rights (ECHR)

Estonia 31, 71, 72, 113; largest database in Europe 77; mandatory DNA sample 78

ethico-political domain, of DNA profiling 4, 4

Europe: communist states in 71; diversity of NGOs within 158-160; DNA database in 32, 32; genetic surveillance 7; regulations for familial searching across $103-107$

European Commission 80

European Court of Human Rights (ECHR) 24

European identity $8-11,13,88$

European integration 13, 79

European Research Council 17n3

European Union (EU) 72; Prüm

Decisions 7, 13, 16n3, 50

exhumations, genetic information from 111

existential insecurity 75

expanding suspicion, in criminal investigation 14, 116; ethical issues and logistical challenges 99-103;

politics of legitimation 107-110, 117;

regulation/regulatory lag 103-107

expansionist legislation 31,78

expansive countries 78

expectations: collective 54,57 ; towards

innovations in forensic genetics

127-128; performative 127; raised by

Prüm system 53-55; and vision 10

eyewitness testimonies 133

false positives $56, \mathbf{6 5}, 102$

familial searching xiii, 7, 14, 25, 27, 29, 30, 32, 79, 125, 179; affected populations 143; civil identification 95-96, 95, 110-116; co-production of biovalue 143-144; criminal investigations $95,95,99-110$; discriminatory potential of 101-102; in Europe 94-118; legislation and ethical issues 97-99; participatory turn in 143; perceived risks of revealing information 100; politics of legitimation 107-110, 117; regulatory gap/on-going regulation 103-107, 106; utility of 107; see also long-range familial searches

FDP see forensic DNA phenotyping (FDP)

Field, Michael 96

fingerprints 2, 22, 24, 27, 35, 50

Finland 31

forensic DNA phenotyping (FDP) xiii, 3, 124, 126, 144, 179; discriminatory potential of 133-134; implementationrelated issues 170-171; individual and collective tensions 128-130; information about biogeographic ancestry 14,30 ; as neutral technology 133; promises 131-135; racial discrimination in $169-170$

forensic genealogy see long-range familial searches

forensic genetics 1, 8-9, 71; biosociality in 182-185; evolution of 27; future research 16, 185-187; historical and sociological analysis of 11 ; innovations and developments in 26, 28-29, 123; preserving social legitimacy 130 ; role/ mission of NGOs 155-158, 158; social risks and ethical challenges 155; trajectory of 26-30, 125-127; transparency about risks of 156 ; unsolved controversies 186; see also 
familial searching; forensic DNA phenotyping (FDP); next generation sequencing (NGS)

forensic practitioners, in Prüm system $55-60$

forensic science 3, 10, 15, 139-142, 179; epistemic authority of 144 ; and familial searching 100; market and commercial interests 97; national development of 84; self-diagnosis 128; solving inefficiency of criminal justice system 35

forensic technocracy 55

France 11, 16n2, 31, 32, 50, 77, 103, 117; criminal DNA databases 35; Elodie

Kulik case 105; familial searching 97

Fussey, Peter 104

Gardner, John 132

GEDmatch 143, 146n2

genetic informant 101

genetic informativity 3,14 ; expansion of 123-124, 124, 138-139, 142-144; see also forensic DNA phenotyping (FDP); next generation sequencing (NGS)

genetic privacy 6, 26, 29, 97, 100-101, 107,116

genetic surveillance 1, 5-7, 6, 66; centralized/decentralized modes of 178; current landscape of 160-171; expansion of $12,77-80,160-166$; in governance of crime 11, 30-34; historical legacy and criminality 74-77; media about expansion 161-163; multiplicity of 26, 34-39; police forces and legacy influence 80-83; in post-communist European countries 71-74, 87-89; racialized 169-171; and suspect communities 167-169; utopian and dystopian visions of 8-11, 180-182; see also Prüm system

GeneWatch UK 173n1

GeNN consortium 110-111

Germany 11, 16n2, 31, 36, 50, 77, 86, 103, 117; awareness of genetics 37; Campaign against DNA collection frenzy $173 n 1$; familial searching 97 ; mass screening in 105-106

Glaser, Barney G. 8

globalization 80

Golden State Killer see DeAngelo, Joseph James
Granja, Rafaela xii, xiii, 30, 113, 143

Greece 51, 58

Gruszczyńska, Beata 75-76

hard facts, of Prüm system 57, 61-62

harmonization, of forensic DNA analysis 55,65

hidden integration 13, 34, 67

"high-tech" innovations 39, 84

Hindmarsh, Richard 5

historical reparation 14, 94, 95, 110-117

human rights $157, \mathbf{1 5 8}$

Hungary $31,71,77$; democratic

backlashes in 72; DNA profiles in 79;

Hungarian Civil Liberties Union $173 n 1$

illegal migration 167

"imaginaries of innovation" 161

imagined communities 13, 181

imagined words 182

Imin, Tahir 22

immigrants 84

Individual-specific 'fingerprints' of human

$D N A$ (Jeffreys) 2; see also Jeffreys, Alec innovations, in forensic genetics 123

interpretative flexibility 13,66

Ireland 31, 58, 59

Isin, Engin 172

Italy $31,51,58,97,113$

Jasanoff, Sheila 9, 11, 35, 39, 49-50, 161,180

Jeffreys, Alec 2, 27, 28

Johnson, Paul 6

juridical-scientific domain, of DNA profiling 3, 4

Khan, Sheila $16 n 3$

Kidd, Kenneth 22-23

Kim, Sang-Hyun 9, 35, 49-50, 180

Konrad, Kornelia 13, 54, 66

Kulik, Elodie 105

Kuus, Marje 85

Latour, Bruno 179

Latvia 31, 71, 72, 77, 78, 113

Lauristin, Marju 88

Le Roux-Kemp, Andra 23, 24-25

legacy, and criminality 74-77

legibility 60

legitimation, politics of 107-110, 117

Levitt, Mairi 184

Lithuania 31, 71, 72, 77, 78 


\section{Index}

Lloyd, James 94

"logic of convergence" 165

long-range familial searches 6, 15, 30, 124, 142-144

Luif, Paul 83

Luxembourg 16n2, 31, 50, 78

Lynch, Michel 3, 183

Lyon, David 5

Machado, Helena xii, xiii, 113, 164, 166

Mager, Astrid 88

Malta 58, 113

Marenin, Otwin 75

Marres, Noortje 166

Maryland v. King case 24

mass screenings 33, 79, 96, 105-106, 109

massive parallel sequencing (MPS) see next-generation sequencing (NGS)

Matos, Sara $16 n 3$

McNally, Ruth 3, 183

McNamara, Michelle 146n1

media, about genetic surveillance expansion 161-163

Michael, Mike 135, 138, 166

Micheli, Marina 154, 157

migrant populations, technological innovations tested on 168

Millan, Stefania 154

missing persons 14, 98; data exchange from different countries 113, 114-115, 116; GeNN consortium 110-111

mixture cases DNA samples 137

Morling, Niels 27, 30

multiplicity, of genetic surveillance 26 , 34-39

National Contact Point (NCP) 12, 15, $16 n 3,51-52,55-56,60$

national DNA databases 24, 33-34, 37, $39,61, \mathbf{6 5}, 105,117,167,178$

NCP see National Contact Point (NCP)

NDNAD (UK's national DNA database) 24, 94, 108, 159

Netherlands $16 n 2,31,32,50,61,77-78$, 103, 113, 117, 130; familial searching 97; Marianne Vaastra murder case 104-105

New York Times 22-23

next generation Prüm 67

next generation sequencing (NGS) 3, 30,

124, 126, 144-145, 179; costs of 139;

ethical issues in using 141; promises

135-139; reliability of 140; research

science $v s$. forensic science 139-142; as revolution 14,138 ; self-anticipatory practices 142

NGOs see Non-Governmental Organizations (NGOs)

NGS see next generation sequencing (NGS)

non-coding genes $96,123,130$

Non-Governmental Organizations (NGOs) 15; diversity within Europe 158-160; expansion 160-166; and genetic surveillance 152-155, 172-173, 184; implementation-related issues in FDP 170-171; racialized 169-171; role/mission in forensic genetic technologies 155-158, 158; and suspect communities 167-169

normative governmentality 80

Novas, Carlos 184

operational domain, of DNA profiling $3-4,4$

opinion polls 164

organized crime 76,167

Pantazis, Christina 167

Parabon Nanolabs 132

partial matching 96, 101, 143

participatory turn, in familial searches 143

Pavlovich, William V. 81

Pavone, Vincenzo xii

Pemberton, Simon 167

performative expectations 127

personalized genetics 145

Pfotenhauer, S. 161

Pieri, Elise 53

Pitchfork, Colin 2, 28

PoFA see Protections of Freedoms Act (PoFA)

Poland 11, 36-38, 71, 76, 78, 113; democratic backlashes in 72; DNA samples 79; DNA technologies 37-38; familial searching 97, 98, 110; GeNN consortium 110-111

police forces: distrust of citizens in 81-82; and influence of legacy $80-83$; and Prüm system 60-65

Polish Genetic Database for the Victims of Totalitarianism 111

population groups $7,35,37,96,127$, 129,145

Portugal 11, 17n3, 31, 36, 58, 61

post-communism 72

post-DNA era $3,5,12,15$

post-socialism 72 
Prainsack, Barbara xi, 5, 52, 55

prospective surveillance $6-7,6$

Protections of Freedoms Act (PoFA) 108

Prüm Decisions 7, 13, 16n3, 50

Prüm system 6, 7, 12, 117, 178, 182;

aspirational component of 53; collective expectations 13, 54, 57, 60, 64; and criminalization of CEE citizens 83-87;

DNA hits within 63; expectations raised by $53-55$; forensic practitioners $55-60$; hard facts of 57, 61-62; international cooperation of law enforcement 60-65; in laboratory 55-60; Malta 58; missing persons data exchange 113, 114-115, 116; modus operandi 51-53; next generation Prüm 67; operational status within 58-59; police forces 60-65; Portugal 58; reciprocal automated searching 33-34, 49; transnational collaboration $54,57,59,65$

public engagement $16,83,171$

public support 105

public surveys 164

Queirós, Filipa 16n3

Quinlan, Andrea 35

Rabinow, Paul 183

race datafication 171

racial discrimination $134,166-167$

recalibration, as innovation work

132

reconstructive surveillance 6,6

regulations, for familial searching across

Europe 103-107

reliability issues 108

Reliability, Utility and LEgitimacy

(RULE) framework 107

research science 15, 139-142

re(con)stitution, of democracy

112-113

restrictive legislation $31-32,78$

retrospecting prospects 138

RNA-sequencing 29, 30

Romania 71-72, 78-79, 84, 113

Rose, Nikolas 184

Rothschild, Joseph 71

RULE framework see Reliability, Utility and LEgitimacy (RULE) framework

Ruppert, Evelyn 172

$S \&$ Marper vs. $U K$ case $40 n 1,108$

Sandhu, Ajay 104
Santos, Filipe 16n3, 31-32, 78

Schengen Agreement 50

Schily, Otto 50

Scotland 31

self-anticipatory practices 142

sensitive information disclosure 97-98, 99

Serbia 86

Shoe rapist case 94-96, 106

Short Tandem Repeat (STR) 96, 126

Silva, Susana 164

single nucleotide polymorphisms

(SNP) 126

Skinner, David 85, 167, 171

Slovakia 31, 71, 72, 77, 78, 113

Slovenia 71, 72, 77, 113

Smith, Lindsay Adams 112, 116

Snapshot 132

SNP see single nucleotide polymorphisms (SNP)

social control xiv, $1,5,11,72,74,184$

social inequalities $97-98$

social legitimacy 107

social sorting $\mathbf{4}, 5,6,33,100$,

173,184

social values 1,184

sociotechnical imaginaries $9,35,50,54$,

65, 180-181

Soviet Republics 72

Spain 16n2, 31, 50, 78, 86, 97

STR see Short Tandem Repeat (STR)

Strauss, Anselm 8

surveillance arbitration 104, 117

surveillance societies 36-37

surveillance vulnerability 73,75

suspect communities 167-168, 171

Svenonius, Ola 72-73, 75

Sweden 31, 61, 143

Tarasova, Ekaterina 72-73

Taylor, Charles 181, 182

techno-optimism 35, 49, 51, 53, 128

technological seduction 35,49

technoscape 182

technosecurity 85

terrorism 167, 185

Thermo Fisher 22-23

Toom, Victor 52, 55

totalitarian regimes 14; distrust and trauma 74; genetic information

from 111; repressive surveillance systems 34

transmitted discrimination 85 


\section{Index}

transmutable past 81

transnational genetic surveillance see Prüm system

Tutton, Richard 184

United Kingdom (UK) 11, 31, 97, 103 , 117 criminal DNA databases 35 ; implementation of familial searching 97; National DNA Database (NDNAD) 24, 94, 108, 159; Protections of Freedoms Act 2012 (PoFA) 108; Shoe rapist case 94-96, 106 United States (US), DNA databases in $24-25,28,39,143,146 n 3$ universal databases 165
Uyghurs, ethnocide in China 22

Vaastra, Marianne see under Netherlands Verovšek, Peter J. 74 visibility 60

vision, and expectations 10

Wee, Sui-Lee 22

Wienroth, Matthias 27, 30, 107, $125,126,140,153-154,169,180$

Williams, Robin 3-5, 6, 27, 30, 153-154, 180

Wingfield, Nancy M. 71

Y-chromosome DNA 126 